\title{
Evaluation of Environmental Impacts of Short Rotation Coppice with Regard to the Amount and Quality of Groundwater Recharge
}

Dissertation to attain the doctoral degree (Dr. forest.) of the Faculty of Forest Sciences and Forest Ecology

Georg-August-University Göttingen

Submitted by

Paul Schmidt-Walter, M.Sc.

born October 17, 1981 in Bremen

Göttingen, 2019 
Examination Board

1. Referee: Prof. Dr. Norbert P. Lamersdorf, Soil Science of Temperate Ecosystems, Forest Sciences, University of Göttingen, Büsgenweg 2, 37077 Göttingen, Germany.

2. Referee: Prof. Dr. Alexander Knohl, Bioclimatology, Forest Sciences, University of Göttingen, Büsgenweg 2, 37077 Göttingen, Germany.

Date of oral examination: 23.09.2019 


\section{Summary}

While there is broad agreement on the positive environmental impacts of short rotation plantations (SRC), possible negative impacts on groundwater recharge due to potentially high water consumption of trees on arabale land are a major issue. The water use of SRCs usually exceeds the water use of arable crops, but can also far exceed the water use of deciduous forests. This leads to a decrease in groundwater recharge, the extent of which is, however, subject to considerable uncertainty and disagreement. In order to expand the knowledge base on SRC water use at the field scale for developing adaptive, sustainable management strategies for woody biomass production systems, field studies on evapotranspiration, groundwater recharge and nitrate leaching were carried out in several SRCs, which differed greatly in their pedo-climatic site conditions, canopy closure, leaf area index and stand age.

The first field study was carried out in the drinking water abstraction area Fuhrberger Feld in order to assess the effects of SRC cultivation on the amount and quality of groundwater recharge. For this purpose, the water balance of a willow SRC and a set-aside arable land was determined with the help of a process-based simulation model, which was validated against observations of soil water tension and stand precipitation. In addition, nitrate concentrations were measured in the seepage water of these field plots and other SRCs of different ages. A second study was carried out to characterise the transpiration and water use strategy (isohydric or anisohydric) of two poplar SRC of contrasting canopy closure and leaf area, in order to evaluate factors potentially influencing SRC water use that can be controlled by management. A third study provided additional information on water use and groundwater recharge of a poplar SRC at near optimum water supply, derived from an inverse modelling approach using the newly developed process-based simulation model LWFBrook90R, which was trained on observations of bulk soil water storage.

Overall, the water consumption of the investigated SRCs varied greatly due to the different site conditions with regard to water supply and evaporation requirements, but in no case exceeded the evapotranspiration of deciduous forests. Nevertheless, the results from the third study showed that the water demand of SRCs can be very high, and transpiration rates greater $500 \mathrm{~mm} \mathrm{y}^{-1}$ can be observed when water supply is ample. The high water demand of SRCs can therefore lead to a considerable decrease in groundwater recharge compared to conventional arable crops, which particularly affects sites with a high plant available soil water storage capacity. For regions with lower soil water availability, the results from the 
willow SRC in the Fuhrberger Feld (transpiration $<300 \mathrm{~mm} \mathrm{y}^{-1}$ ) indicate that the high water demand of SRCs is not covered for the majority of sites potentially available for SRC cultivation (i.e., marginal arable land). On the one hand a low soil water availability leads to lower biomass yields, but on the other hand also limits a potential reduction in groundwater recharge. Considering also nitrate concentrations in seepage water of SRCs in the Fuhrbeger Feld, it can be concluded that the environmental impacts of SRC cultivation do not conflict with the protection requirements respecting the amount and quality of groundwater recharge in the Fuhrberger Feld water abstraction area.

The results of the second study, which investigates the water use patterns of two poplar plantations, indicated that there is a certain potential for manipulating SRC water use through informed management. The differences in total evapotranspiration between the two SRCs of contrasting canopy closure and leaf area index were small, and strategies to limit leaf area or canopy closure appeared to be of secondary importance for the total evapotranspiration of SRC. However, a promising option for actually influencing transpiration through management decisions seems to be the water use strategy of the plant material. While isohydric poplar hybrids efficiently control transpiration with increasing evaporative demand, anisohydric poplar hybrids maintain high stomatal conductance even when evaporative demand is high, and soil water availability is low. This can lead to very large differences in the transpiration rate of poplar clones of different provenence. Since the water use strategy also influences biomass yields and site suitability of individual poplar hybrids, information on the water use behaviour of individual poplar clones could be used to make an informed selection of plant material that is optimally adapted to the ecological and economic requirements of a production site. For this purpose, a data base should be created, with regard to increasing land requirements for the production of woody biomass, but also with regard to the effects of climate change. 


\section{Zusammenfasssung}

Titel: Beurteilung der Umweltwirkungen von Kurzumtriebsplantagen hinsichtlich der Menge und Qualität von Sickerwasser

Während über die positiven Umweltauswirkungen von Kurzumtriebsplantagen (KUP) weitgehend Einigkeit herrscht, sind potentiell negative Auswirkungen auf die Grundwasserneubildungsmenge aufgrund eines potentiell hohen Wasserverbrauchs ein großes Thema. Der Wasserverbrauch von KUP übersteigt in der Regel den Wasserverbrauch von Ackerkulturen, kann aber auch den Wasserverbrauch von Laubwälder bei weitem übersteigen. Dadurch kommt es zu einer Abnahme der Grundwasserneubildung, über deren Ausmaß jedoch große Unsicherheit und auch Uneinigkeit besteht. Um die Wissensgrundlagen zum Wasserverbauch von KUP auf Standortebene zu erweitern, und um Faktoren zu identifizieren, die den Wasserverbrauch von KUPs beeinflussen, wurden mehrere Feldstudien zu Verdunstung, Grundwasserneubildung und Nitratauswaschung in mehreren KUPs durchgeführt, die sich in ihren standörtlichen Vorraussetzungen, dem Kronenschlussgrad, dem Blattenflächenindex und dem Bestandesalter zum Teil stark unterschieden.

Die erste Feldstudie wurde im Trinkwassergewinnungsgebiet Fuhrberger Feld durchgeführt, um die Auswirkungen des Anbaus von KUP hinsichtlich Menge und Qualität der Grundwasserneubildung zu bewerten. Zu diesem Zweck wurde der Wasserhaushalt einer Weiden-KUP und einer stillgelegten Ackerfläche mit Hilfe eines prozessbasierten Simulationsmodells bestimmt, welches mit Beobachtungen zu Bodenwasserspannung und Bestandesniederschlag validiert wurde. Zusätzlich wurden Nitratkonzentrationen im Sickerwasser dieser Versuchsflächen und weiterer KUPs unterschiedlichen Alters erhoben. Eine zweite Studie wurde durchgeführt, um die Verdunstung und die Wassernutzungstrategie (isohydrisch oder anisohydrisch) zweier Pappel-KUPs mit unterschiedlichem Kronenschlussgrad und unterschiedlicher Blattfläche $\mathrm{zu}$ charakterisieren. Hieraus sollten Faktoren abgeleitet werden, die den Wasserverbrauch von KUPs beeinflussen können, und gleichzeitig durch Managemententscheidungen beeinflussbar sind. Eine dritte Studie lieferte zusätzliche Informationen zu Wasserverbrauch und Grundwasserneubildung einer PappelKUP mit nahezu optimaler Wasserversorgung.

Insgesamt variierte der Wasserverbauch der untersuchten KUPs aufgrund der unterschiedlichen standörtlichen Gegebenheiten hinsichtlich Wasserversorgung und Verdunstungsbedarf sehr stark, überstieg jedoch in keinem Fall die Evapotranspiration von 
Laubwäldern. Die Ergebnisse der dritten Studie zeigten jedoch, dass der Wasserbedarf von KUPs sehr hoch sein kann, und dass bei ausreichender Wasserversorgung mit Transpirationsraten von mehr als $500 \mathrm{~mm} \mathrm{a}^{-1}$ durchaus gerechnet werden muss. Der hohe Wasserbedarf von KUPs kann daher eine erhebliche Abnahme der Grundwasserneubildung im Vergleich zu annuellen Ackerkulturen mit sich bringen, von der insbesondere Standorte mit einer hohen pflanzenverfügbaren Wasserspeicherungskapazität betroffen sind. Für Regionen mit geringerer Wasserverfügbarkeit deuten die Ergebnisse der Weiden-KUP im Fuhrberger Feld, mit vergleichweise geringen Transpirationsraten $\left(<300 \mathrm{~mm} \mathrm{a}^{-1}\right)$ darauf hin, dass der hohe Wasserbedarf von KUPs für eine Vielzahl potentieller KUP-Standorte (i.e. Ackerböden geringen Ertragsniveaus) nicht gedeckt wird. Dadurch werden einserseits geringere Biomasseerträgen erzielt, andererseits wird aber auch die Abnahme der Grundwasserneubildung begrenzt. Speziell für das Fuhrberger Feld kann unter Hinzunahme der Erkenntnisse zur Nitratbelastung des Sickerwassers der untersuchten KUPs geschlussfolgert werden, dass der Anbau von KUP gut mit den Anforderungen des Grundwasserschutzes hinsichtlich Menge und Qualität vereinbar ist.

Die Ergebnisse der zweiten Studie, die das Verdunstungsverhalten zweier Pappelplantagen untersucht, deuteten darauf hin, dass ein gewisses Potenzial zur Manipulation der Verdunstung von KUPs durch geschicktes Management besteht. Die Unterschiede im Gesamtwasserverbrauch zwischen den beiden KUPs waren zwar gering, und Strategien zur Begrenzung der Blattfläche oder des Kronenschlussgrads erschienen daher für die Gesamtverdunstung von KUP von untergeordneter Bedeutung. Eine vielversprechende Option zur tatsächlichen Beeinflussung der Verdunstung durch Managemententscheidungen scheint jedoch die Wassernutzungsstrategie des Pflanzmaterials zu sein. Während isohydrische Pappelhybriden die Transpiration mit steigendem Verdunstungsanspruch der Atmosphäre effizient abregeln, bleiben die Spaltöffnungen bei anisohydrischen Pappelhybriden weiter geöffnet, was $\mathrm{zu}$ sehr großen Unterschieden in der Transpirationleistung von Pappelklonen unterschiedlicher Herkunft führen kann. Da die Wassernutzungsstrategie auch den Biomassertrag und die Standortseignung beeinflusst, könnte mithilfe von Informationen zum Verdunstungsverhalten kommerziell vermarkteter Pappelhybriden eine sachkundige Auswahl von Klonmaterial erfolgen, welches optimal auf die ökologischen und ökonomischen Ansprüche eines Produktionsstandortes abgestimmt ist. Hierfür sollte vor dem Hintergrund eines möglicherweise steigenden Flächenbedarfs zur Erzeugung holziger Biomasse, aber auch hinsichtlich der Auswirkungen des Klimawandels eine Datenbasis geschaffen werden. 


\section{Table of Contents}

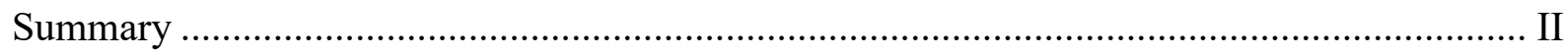

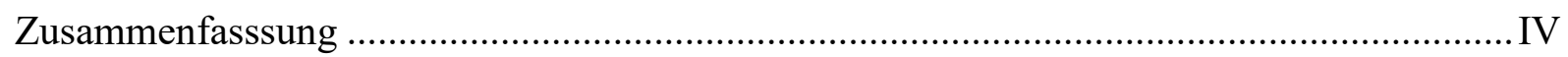

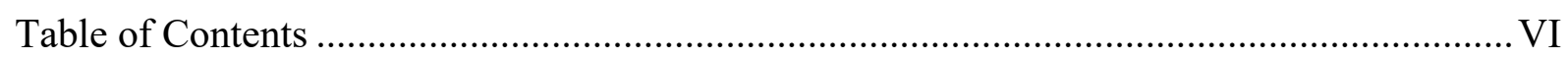

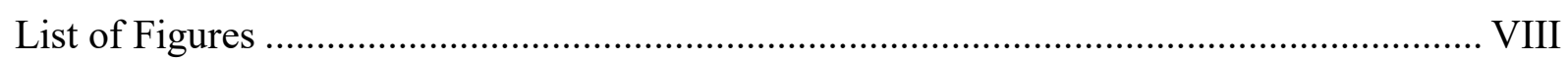

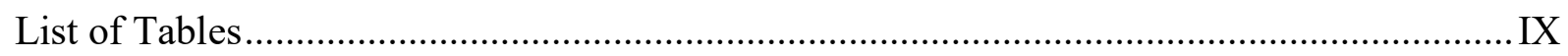

Chapter 1: General Introduction ............................................................................ 1

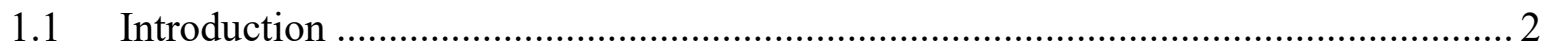

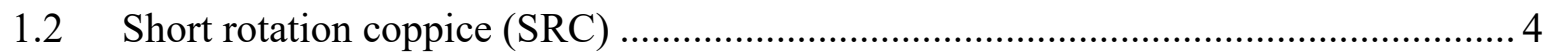

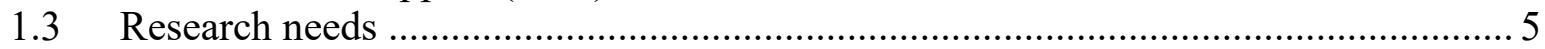

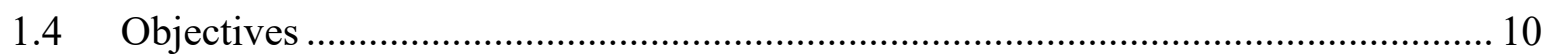

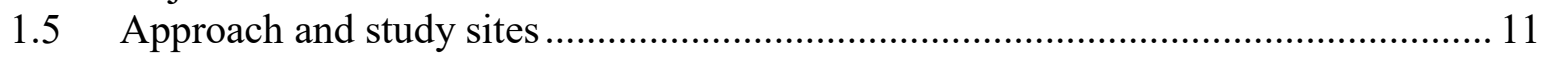

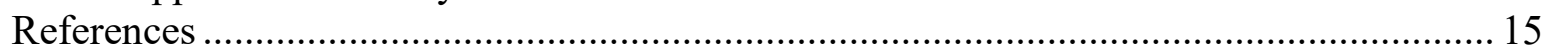

Chapter 2: Biomass Production in Water Sensitive Areas .................................................... 20

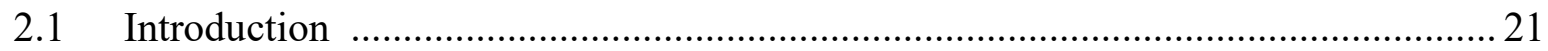

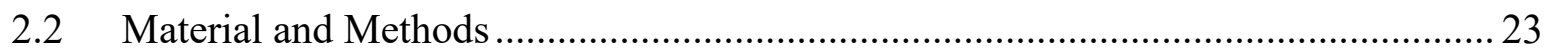

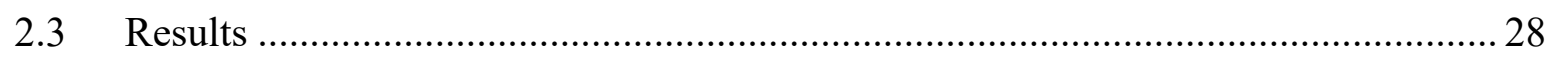

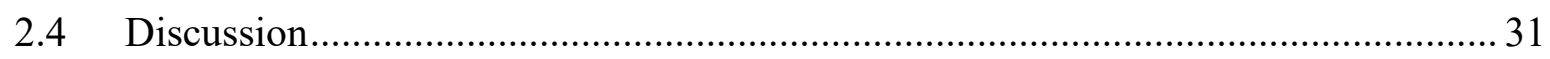

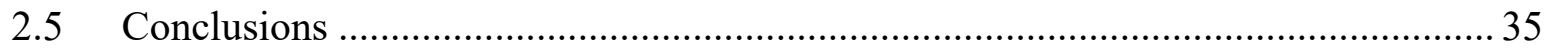

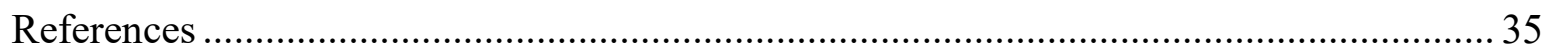

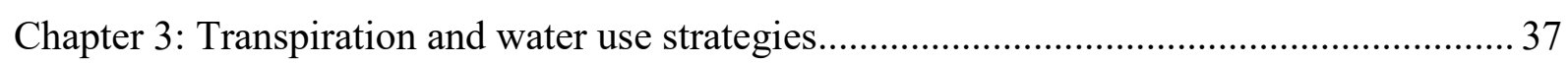

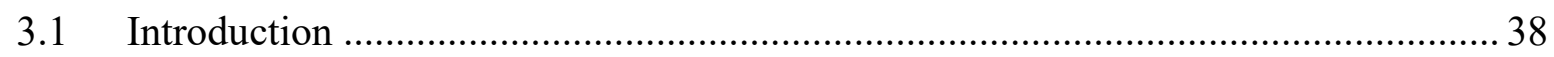

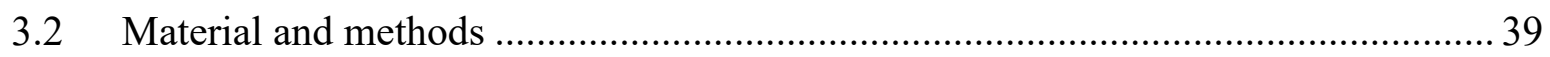

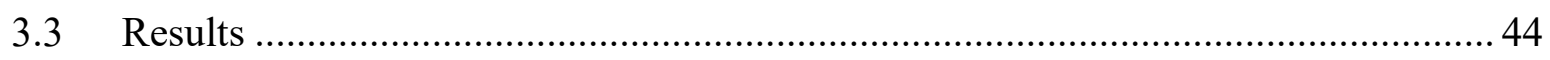

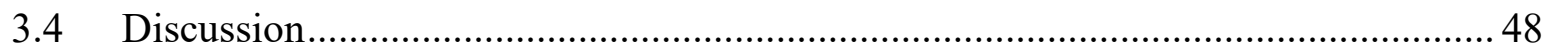

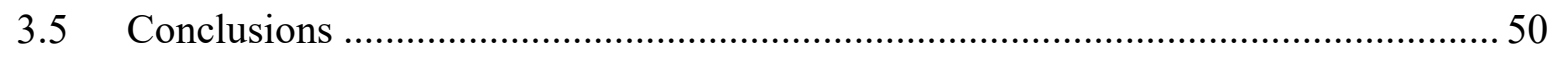

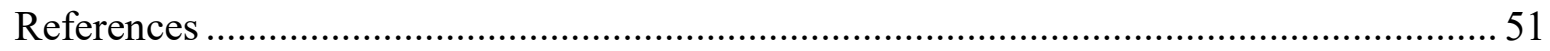

Chapter 4: LWFBrook90R - Case Study Kaufering Poplar SRC ............................................. 53

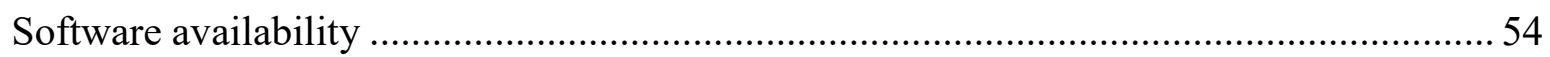

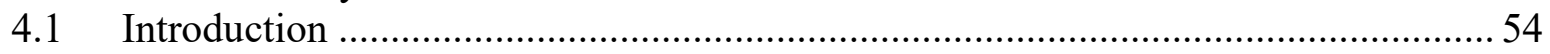

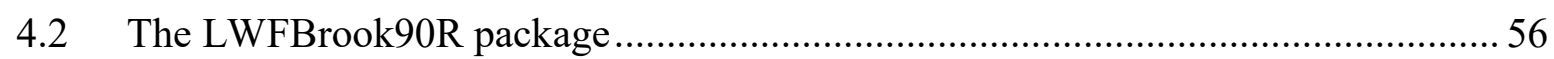

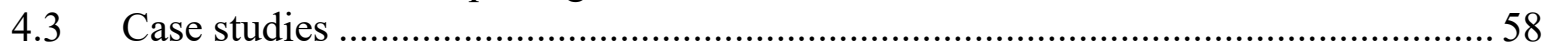

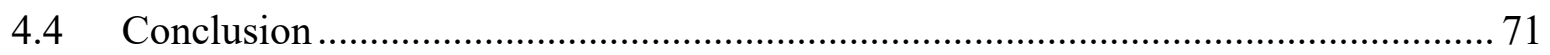

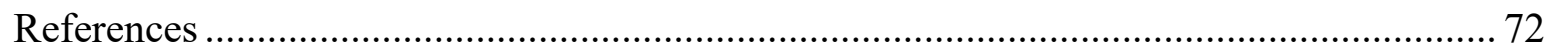

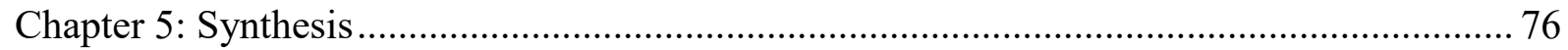

5.1 SRC water use and groundwater recharge .............................................................. 77

5.2 Influence of canopy closure and leaf area on SRC evapotranspiration ......................8 80

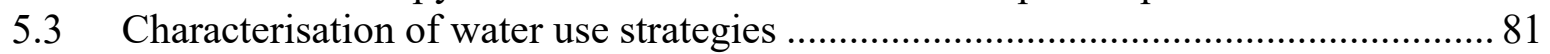

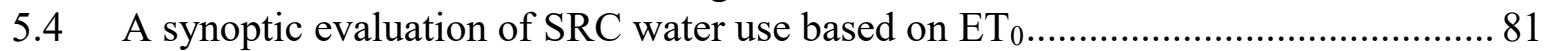

5.5 Implications for SRC management.................................................................... 83

5.6 An assessment of the effects of SRC cultivation on groundwater quality and quantity

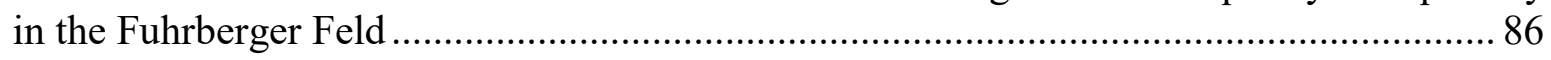

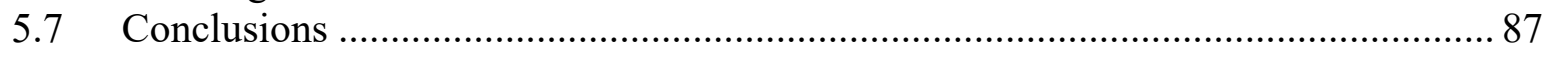


References

Declaration of originality and confirmation of conformance ........................................ 91

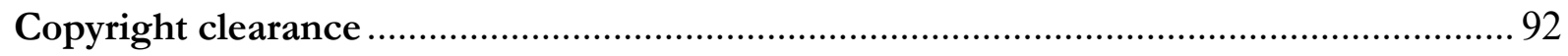

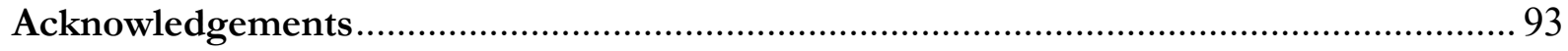

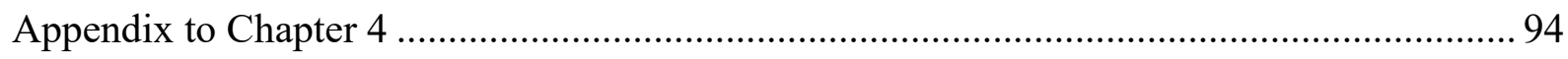

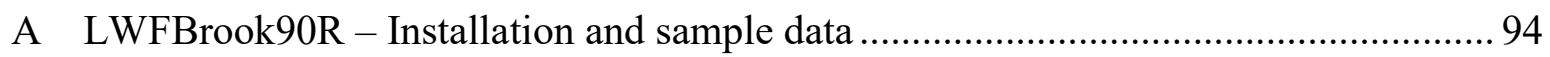

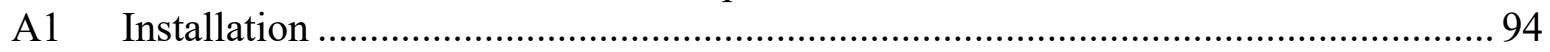

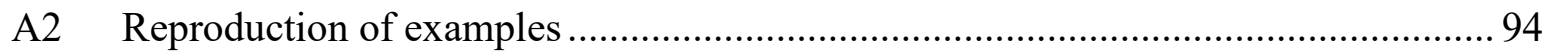

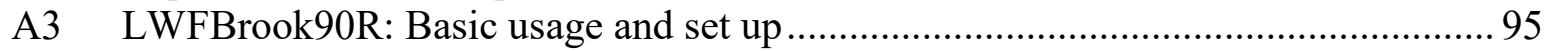

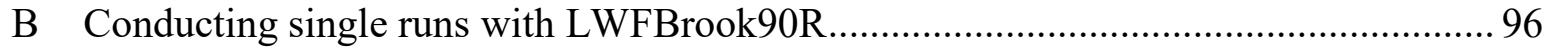

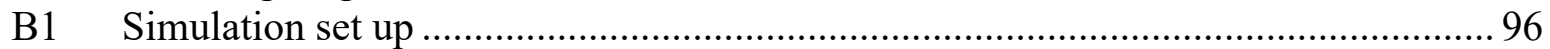

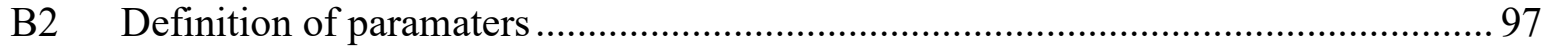

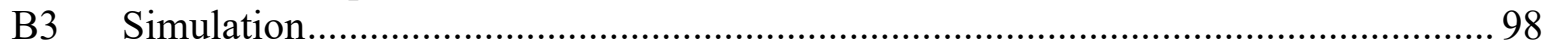

C Calibration \& sensitivity analysis of "Kaufering Pappel Schacht 2011-2012".......... 101

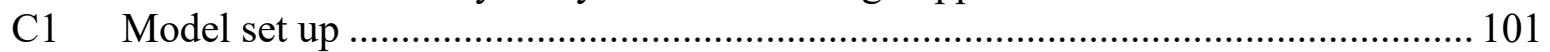

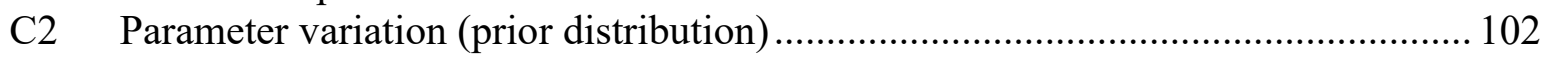

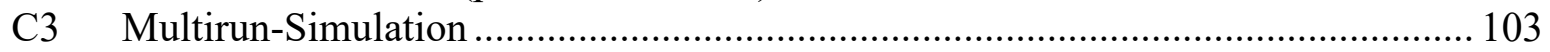

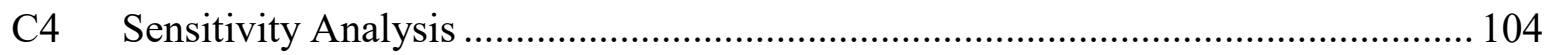

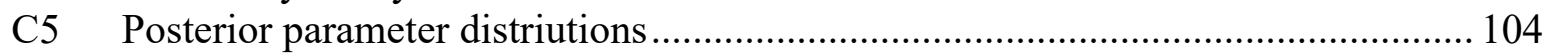

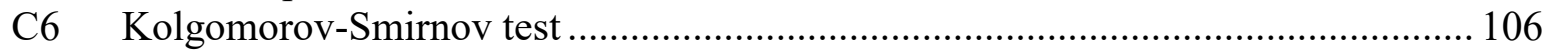

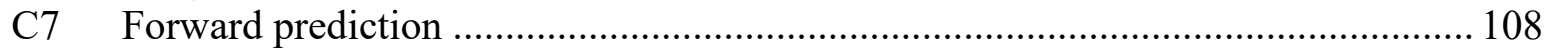

D Bayesian calibration of "Kaufering Pappel Schacht 2011-2012" .............................. 112

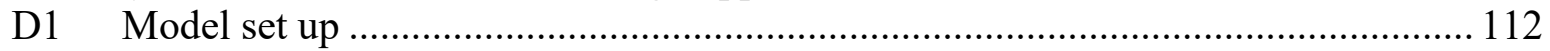

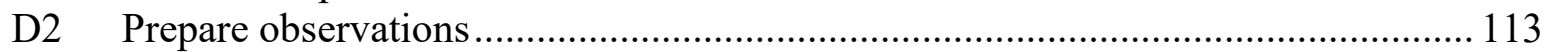

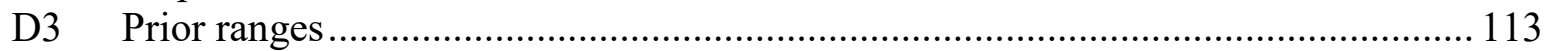

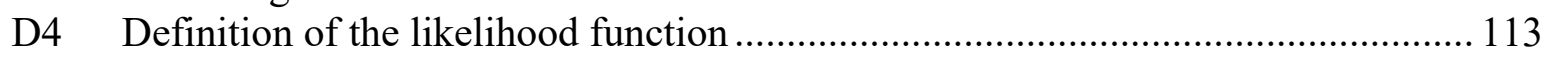

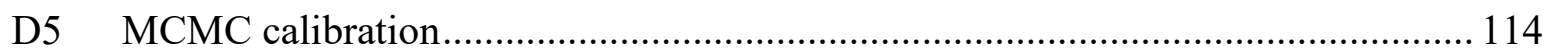

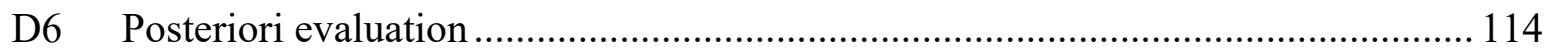

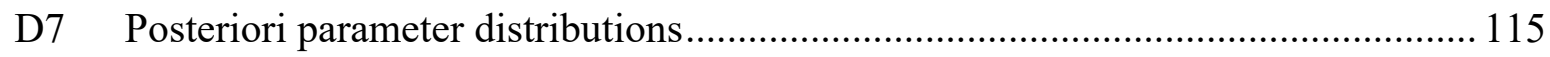

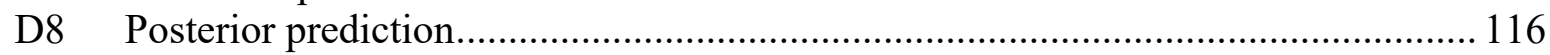




\section{List of Figures}

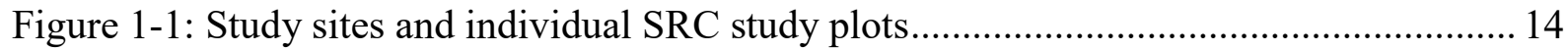

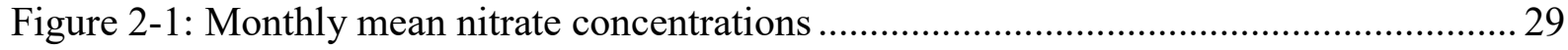

Figure 2-2: Simulated and observed soil water tensions ................................................... 31

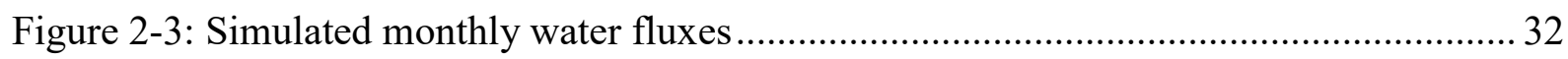

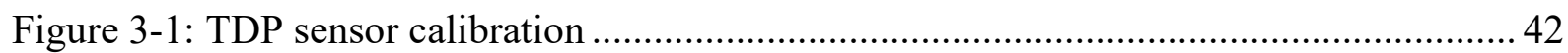

Figure 3-2: Meteorological conditions, soil water content and leaf area index ...................... 44

Figure 3-3: Daily sums of evapotranspiration and reference evaporation ............................. 45

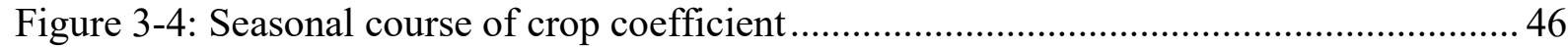

Figure 3-5: Daily mean canopy conductance under reference conditions ............................. 46

Figure 3-6: Hourly values of canopy conductance vs. vapor pressure deficit ........................ 47

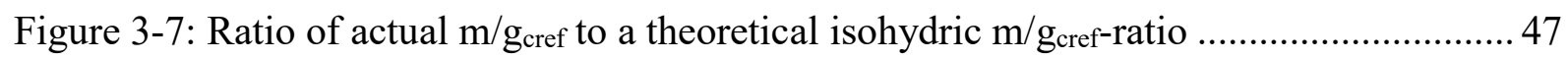

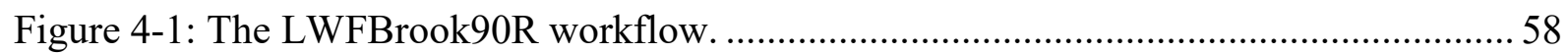

Figure 4-2: Mean monthly water fluxes of three cover types. ........................................... 61

Figure 4-3: Mean daily soil water potential of the three vegetation cover types. .................... 61

Figure 4-4: Maximum difference $D_{\max }$ between the ECDFs of parameters............................ 64

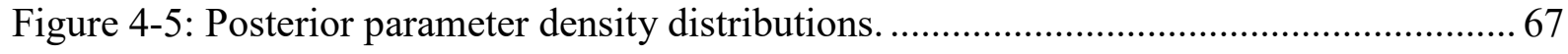

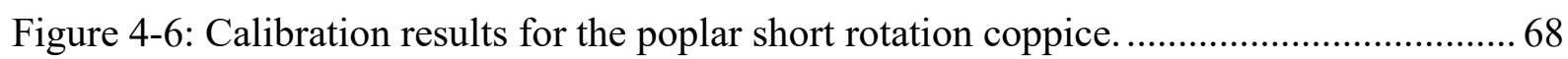




\section{List of Tables}

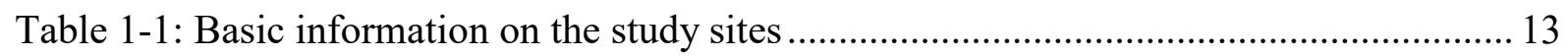

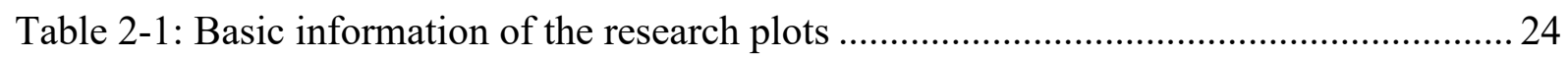

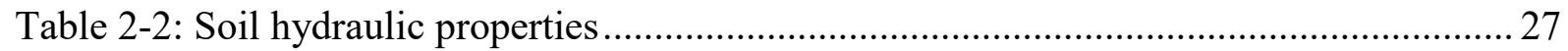

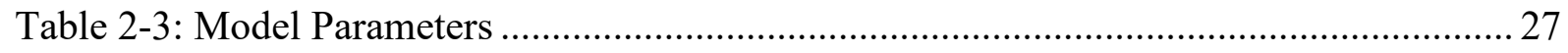

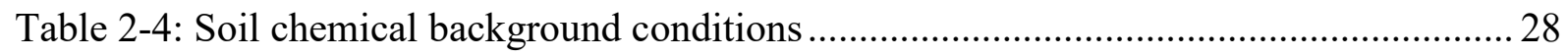

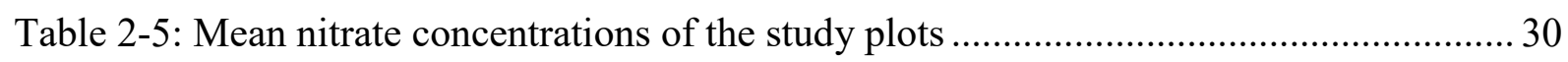

Table 2-6: Performance statistics of simulated soil water tensions and throughfall ................ 31

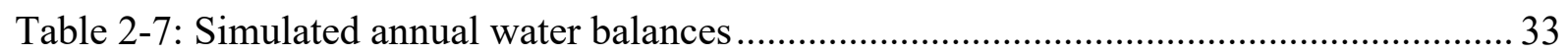

Table 2-8: Cumulated drainage water fluxes and nitrate leaching ....................................... 34

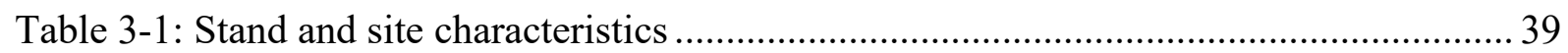

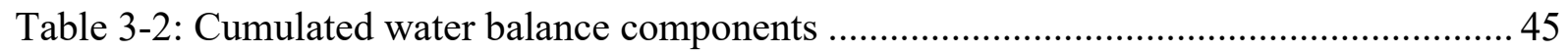

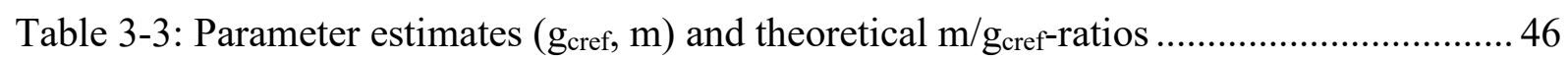

Table 4-1: Input parameters for the three vegetation cover types........................................ 60

Table 4-2: Parameters and their prior ranges selected for sensitivity analysis. .......................63

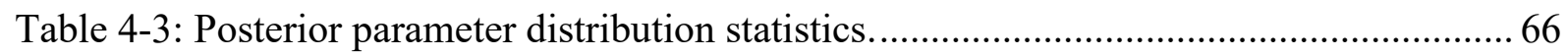

Table 4-4: Predicted annual water fluxes for the Poplar SRC and the three vegetation covers at the Kaufering site. 
Chapter 1

General Introduction

Paul Schmidt-Walter 


\subsection{Introduction}

As early as 1974, bioenergy production systems gained considerable attention by authorities all over the world, in search of alternative resources of energy to diminish the dependency on fossil fuel, of which oil-importing countries at that time had painfully become aware. In temperate and northern climates, biomass from Short Rotation Coppice systems (SRC) using poplar (Populus ssp.), willow (Salix ssp.) and other mainly broad leaved tree species was considered a promising alternative energy resource, due to the fast growth of the trees, the easy propagation of plant material as cuttings, and their vigorous sprouting following harvest. Additionally, there was a long history of breeding and selection programs particularly for poplar hybrids, dating back to the 1920s (Dickmann, 2006), upon which new research could be built to increase the productivity of SRCs.

Since then, several drivers stimulated the cultivation of and research on fast-growing trees on agricultural land. As a consequence of overproduction, the EU's Common Agricultural Policy (CAP) introduced production quotas for agricultural goods and set-aside schemes in the late 1980s, which made European farmers seek for alternative land use options (Lindegaard et al., 2016). SRCs appeared as an attractive income diversification option and alternative to traditional farming, and were first implemented at a larger scale in Sweden using fast-growing willow clones (Verwijst et al., 2013).

The Earth Summit in Rio (1992) and the adoption of the Kyoto Protocol (1997) formed other indirect milestones for SRC cultivation, when it was broadly realised that the excessive use of fossil fuels caused global warming due to the enhanced greenhouse effect. The need for alternative, sustainable sources to substitute fossil fuels and mitigate greenhouse gas (GHG) emissions in the 1990s drove a veritable boom in research funding and cultivation of SRC systems that also led to first research activities on environmental aspects of SRC in Sweden and UK. This research contributed markedly to the general recognition of SRC as a sustainable, environmental friendly bioenergy production system, providing positive effects on nitrogen $(\mathrm{N})$ retention and groundwater quality (Makeschin, 1994), biodiversity (Heilmann et al., 1995), and soil functions (Jug et al., 1999b; Lamersdorf et al., 2010), when replacing annual crops. However, the mentioned research episode also established the reputation of SRCs being excessive water consumers (Hall et al., 1998; Persson, 1997; Persson and Lindroth, 1994), that can affect local water balances and decrease groundwater resources when cultivated in a larger scale. 
More recently, policy aspirations to reach renewable energy and climate change targets again increased the attention for short rotation bioenergy production systems in Europe including Germany. Comparative field studies showed that SRC emit $40 \%$ to $>99 \%$ less nitrous oxide $\left(\mathrm{N}_{2} \mathrm{O}\right)$ than annual bioenergy crops (Don et al., 2012; Drewer et al., 2012; Gelfand et al., 2013; Hellebrand et al., 2010). Nitrous oxide is a trace gas bearing a 300 times larger global warming potential than $\mathrm{CO}_{2}$, and emissions from annual bioenergy crop production often put the fossil fuel offset benefits of the produced biomass at risk (Robertson et al., 2000). Due to reduced $\mathrm{N}_{2} \mathrm{O}$ emissions, SRC have a better GHG balance, which alone can gain a GHG mitigation advantage of $1 \mathrm{Mg} \mathrm{ha}^{-1} \mathrm{y}^{-1} \mathrm{CO}_{2}$-equivalent $\left(\mathrm{CO}_{2}\right.$-eq) over annual bioenergy crops during the production phase (Hellebrand et al., 2010). Therefore, SRCs were recommended to become part of an overall strategy to achieve the minimum GHG emission reduction targets (Njakou Djomo et al., 2011) as required by the EU Renewable Energy Directive (RED).

In order to increase the share of renewable energy to $20 \%$ of the total energy consumption by 2020 , and to $50 \%$ by 2050 , an increased demand of biomass for bioenergy feedstock was predicted for Europe. In Germany, where wood is the most important renewable energy source for heating, scenario calculations projected a gap in annual wood supply for energy and material use of 270 PJ by 2020 (Thrän et al., 2009), corresponding to 40 million $\mathrm{m}^{3}$ of wood. Under the current forest strategy ensuring a multi-functional, ecologically sustainable forestry sector, well-equipped to face climate change (BMELV, 2011), this gap could be bridged only in the short term by mobilising additional wood resources from legal and sustainable forestry. In the medium to long term, however, an increased demand for bioenergy should be supplied by a considerable contribution of woody biomass from SRC, for which an area increase of 400,000-500,000 ha by 2020 would be necessary (Nitsch, 2008). However, the area cultivated with SRC in 2014 amounted to only 6,000 ha (DBFZ, 2015).

Throughout Europe, the expected area increase for woody biomass production in the late 2000s was large. Without putting additional pressure on food production, as much as 17.5 million ha could potentially be cultivated with environmental friendly bioenergy productions systems such as SRC (EEA, 2006), without the need to convert grassland or other extensively cultivated areas to arable land. If only a notable portion of the available land indeed would be afforested with SRCs, a more profound analysis of environmental impacts of SRC cultivations is required. Moreover, there is the need to complement existent knowledge on environmental impacts of SRC, in order to derive management strategies that have the potential to mitigate 
possible negative effects such as reduced groundwater recharge, and amplify positive effects of SRC cultivation on the environment.

The large expectations in area increase gave the impulse to initialise the ERA-NET Bioenergy project "Reducing environmental impacts of SRC through evidence-based integrated decision support tools" (RATING-SRC). The project work package "Impact of SRC on water balance and water quality" provided the starting point for the dissertation at hand. The work was additionally funded by the municipal water and energy supplier of the city of Hanover (Enercity), who consider the production of woody biomass for heat and energy production in their drinking water production area Fuhrberger Feld as a promising option to reactivate land that was previously set aside to protect groundwater resources from nitrate pollution. With the underlying aim to identify potential to mitigate negative effects on the amount and quality of seepage water from short rotation coppice, three field studies were conducted in SRCs in the Fuhrberger Feld and other locations. The focus thereby was on SRC water use and related effects on groundwater recharge, as this is the major concern of woody biomass production on arable land. Here, the results of these studies are compiled and their conclusions are synthesized in order to support the development of management schemes and strategies for sustainable and water-efficient SRC woody biomass production systems. In this context, the remainder of this introductory chapter will first provide a more detailed insight into the characteristics of short rotation woody biomass production systems. Subsequently, a brief overview of the literature on environmental impacts of SRC is provided, through which the objectives of this work are derived. The objectives are addressed in the Chapters 2-4, and the respective conclusions summarized and synthesised in the last chapter (Chapter 5), with regard to the currently available literature on SRC water use.

\subsection{Short rotation coppice (SRC)}

Since ancient times, poplars and willows have been utilized to produce firewood, construction timber, fodder and raw material for handicraft products. While the latter two can be regarded as less important in modern times, the production of fuel wood and to lesser extent also timber, is the central motivation for establishing short rotation coppices on arable land. The definition of 'coppice' is linked to a formerly widespread practice of forestry, 'in which the trees and shrubs are periodically cut back to ground level to stimulate growth and provide firewood' (Oxford English Dictionary), while Drew et al. (1987) provide a definition for SRCs, that clearly points out characteristics of an agricultural land use form: 
'A silvicultural system based upon short clear-felling cycles generally between one and 15 years, employing intensive cultural techniques such as fertilization, irrigation and weed control, and utilising genetically superior planting material.'

Thereby, a central element is the ability of the plant material to re-sprout after harvest, which makes deciduous tree species of vigorous juvenile growth like poplars and willows particularly suited for SRC systems. SRCs are harvested in intervals of 2-20 years, depending on the targeted wood product. For the production of fuel wood in the form of wood chips, willow plantations are typically harvested in shorter rotation periods of 2-4 years, and poplar plantations are mostly managed in longer rotation periods of 4-8 years. Harvesting intervals greater 10 years are mostly used to produce wood for material use and firewood, and primarily apply to poplar, or other tree species suitable for SRC cultivation such as black locust (Robinia pseudoacacia, L.).

Although the above quoted definition suggests an intensive agricultural production system, SRCs are seen as an extensive form of agricultural land use. Except for the planting process, SRC require very low inputs of energy and labour. Planting is usually made from wood cuttings of $20 \mathrm{~cm}$ length, which are manually or mechanically put into the soil. Depending on the targeted wood product, tree species and rotation period, plant densities of up to 20,000 trees per ha are realised. However, typical plant densities for willow SRCs are 13,000 ha $\mathrm{h}^{-1}$ in double rows, and 2,000-9,000 ha $\mathrm{ha}^{-1}$ in single rows for poplar, with densities below $5000 \mathrm{ha}^{-1}$ typically planted for longer rotation periods. Prior to planting, the soil is ploughed to remove previous vegetation, and pre-emergent herbicides are applied to give the trees a head start over weeds and other plants. Application of fertilization during the first rotation period or prior to planting is not recommended, due to often high nutrient contents of former cropland. The nutrient reserves are usually sufficient to supply tree growth over the lifetime of an SRC (15-30 years), as nutrient removal with biomass is currently compensated by atmospheric deposition (Petzold et al., 2010).

\subsection{Research needs}

\subsubsection{Groundwater quality}

Apart from a superior GHG balance over annual bioenergy crops, the production of woody biomass using SRC provides unique ecosystem services when compared to biomass production using annual food or dedicated bioenergy crops, for which Lamersdorf et al. (2010) give an overview. The permanent vegetation cover and an extensive, persistent root 
system with a high uptake potential for nutrients and water reduce surface runoff and soil erosion (Holder et al., 2019; Petzold et al., 2009), and can contribute to improved flood risk prevention (Wahren et al., 2012) in catchments dominated by agricultural land use. A central environmental advantage over annual bioenergy crops are reduced nitrate $\left(\mathrm{NO}_{3}\right)$ leaching rates (Makeschin, 1994) and related positive effects on groundwater and surface water quality. Extensive research from Sweden showed that groundwater $\mathrm{NO}_{3}$ concentrations in SRC were lower than in annual crops, even when high N-dosages were applied as fertiliser or sewage sludge (Aronsson et al., 2000; Dimitriou et al., 2012; Dimitriou and Mola-Yudego, 2017). Direct observations of $\mathrm{NO}_{3}$ leaching confirm reduced nitrate output with seepage water of SRC compared to annual crops (Goodlass et al., 2007; Kern et al., 2010). The reduction can be attributed to the high $\mathrm{N}$ uptake potential (Dimitriou and Aronsson, 2011, 2004), slow mineralisation of organic N compounds due to no-till management (Jug et al., 1999b), and effective $\mathrm{N}$ cycling with litter fall (Meiresonne et al., 2007).

The mentioned positive effects on $\mathrm{N}$ retention are usually observed after an initial phase of stand establishment. A critical phase in the lifetime of an SRC is the year of planting, when considerable amounts of organic $\mathrm{N}$ are potentially mineralised due to soil preparation (ploughing) prior to planting. In this phase, a vegetation cover to sufficiently "catch" excess nitrogen is still lacking, and nitrate leaching peaks can be observed (Goodlass et al., 2007; Makeschin, 1994). Such seepage concentration peaks can exceed the legal threshold for drinking water of $11.3 \mathrm{mg} \mathrm{NO}_{3}-\mathrm{N} \mathrm{L}^{-1}$, and might contaminate adjacent water bodies or aquifers.

Even though a general reduction of nitrate leaching can be expected when SRC replace annual crops, the risk of nitrate leaching from SRC cultivation has to be considered in drinking water abstraction areas such as the Fuhrberger Feld. Due to the land use history and high groundwater levels, the soils in the Fuhrberger Feld are enriched with high amounts of organic carbon, which are currently in transition to lower levels due to the lowering of the groundwater level since the 1960s (Springob et al., 2001). Thereby, the soils release nitrogen (Köhler et al., 2006). To protect the groundwater bodies against nitrate pollution, arable land was set aside to lie fallow, in order to avoid groundwater pollution induced by fertilizer applications, but also to decelerate the mineralisation process. However, it is currently unknown how these soils react to SRC cultivation, i.e. whether the risk of nitrate leaching is increased or decreased in the long run. 


\subsubsection{SRC water use and groundwater recharge}

While there is broad agreement on the mentioned positive environmental effects arising from a high uptake potential for water and nutrients, the very same characteristic properties of SRC are a major concern, due to potential negative effects on local water balances caused by the high water consumption of poplar and willow plantations. In this context, evapotranspiration (E) rates are reported for both species, that not only exceed the water use of annual crops, which SRC might replace, but also exceed water use of temperate deciduous forests (Stephens et al., 2001). At an annual timescale, SRC in temperate climates can approach $\mathrm{E}$ rates in the range of evergreen coniferous forests (Persson, 1997), of more than $600 \mathrm{~mm} \mathrm{y}^{-1}$ (Finch et al., 2004; Hall et al., 1996; Lindroth et al., 1994; Zalesny et al., 2006). Such high E rates have the potential to markedly reduce aquifer recharge and streamflow, when SRC replace annual crops in a larger scale (Bredemeier et al., 2015; Perry et al., 2001). Evapotranspiration is the sum of interception evaporation $\left(E_{i}\right)$, transpiration $\left(E_{t}\right)$ and soil and snow evaporation $\left(E_{s}\right)$, and is directly related to groundwater recharge $(G W R)$ and surface runoff $(R)$ via the water balance equation

$$
P=E_{t}+E_{i}+E_{s}+G W R+R+\Delta S
$$

where $\Delta S$ is the change in soil water storage and $P$ is precipitation. A large shift in the local water balance towards higher $\mathrm{E}$ therefore can impact adjacent water sensitive ecosystems (Petzold et al., 2011) and might put the main product of water abstraction areas (i.e., drinking water) such as the Fuhrberger Feld, at risk. In the Fuhrberger Feld, a land use form with a water use comparable to that of Scots pine forests, which predominate in the area, would be inacceptable. This is reflected in the efforts to increase groundwater recharge by transferring pine forests in the area to deciduous woodland, across all types of land ownership (Quirin et al., 2017). However, it currently remains unclear if the water use of SRC in the Fuhrberger Feld approaches evapotranspiration of coniferous forests, because of differing appraisals with regard to the water demand of SRC.

There is a high degree of uncertainty about the actual water demand of SRCs, which makes it difficult to estimate the extent of negative effects of SRC on groundwater recharge. While early studies on SRC water consumption reported a very high water demand (Hall et al., 1996; Persson and Lindroth, 1994), that eventually established the reputation of willows and poplars being excessive water consumers, a comprehensive literature overview provided by Fischer et al. (2013) suggests that for a majority of studies, annual E of SRC is lower than reference evaporation $\left(\mathrm{ET}_{0}\right)$ of a grass surface with unlimited water supply (Allen et al., 
1998). For these studies (e.g. Bungart and Hüttl, 2004; Fischer et al., 2013; Lasch et al., 2010), E was in the range of $450-600 \mathrm{~mm} \mathrm{y}^{-1}$, and the empirical crop coefficient $\left(\mathrm{K}_{\mathrm{c}}\right)$, calculated as the ratio between $\mathrm{E}_{\text {and }} \mathrm{ET}_{0}$, is remarkably constant over a range of $0.8-0.9$ (Fischer et al., 2018). For this reason, most of the variability in $\mathrm{E}$ can be explained by differences in pedo-climatic conditions that determine evaporative demand and water supply. Nonetheless, it remains unclear, whether this crop coefficient is stable due to an in fact relatively steady and moderate water demand being lower than $\mathrm{ET}_{0}$, or because of an actually higher water demand, that on average simply is not satisfied from precipitation and plant available soil water resources.

In order to assess the potential water demand of poplar and willow SRC, it is worth considering the observations outside the average $\mathrm{K}_{\mathrm{c}}$ range proposed by Fischer et al. (2018). In this context, the already mentioned early studies on SRC water use ("water use" hereafter used synonymous with E) showed crop coefficient well above 1 (Hall et al., 1996; Persson, 1997; Persson and Lindroth, 1994, cf. Fischer et al 2013). In these studies, water availability was not a limiting factor, and the higher crop coefficients most likely indicate an indeed high water demand of the SRCs. More recently, such high evaporative potential was confirmed for a poplar SRC in Germany (Petzold et al., 2011), even though the annual $\mathrm{K}_{\mathrm{c}}$ of 1.12 was probably lowered due to limited water availability in the late growing season. However, these results were again contrasted by studies from Belgium and the Czech Republic, that report comparatively low $\mathrm{E}$ and low $\mathrm{K}_{\mathrm{c}}$ (Fischer et al., 2013; Zenone et al., 2015), without indication of water stress. Consequently, relative differences in SRC water demand and potential water use appear to be present in the literature. This uncertainty in the evaporative potential of SRC needs to be addressed by additional studies on SRC water use, and determinants need to be identified that control the water demand of SRCs. With the knowledge of these determinants, informed SRC management decisions can be made, in order to mitigate adverse hydrological effects from excessive water use of SRC, and water-efficient, water-saving woody biomass production systems can be designed, optimally adapted to the given site conditions and possible requirements of groundwater protection. An increased water-efficiency of SRC in turn might also increase biomass yields, as the water availability is often reported to be the main factor limiting SRC productivity (Jug et al., 1999a; Linderson et al., 2007; Lindroth and Båth, 1999). Extended insights into the water use and water demand of SRCs therefore can help to develop adaptive, sustainable management strategies for woody biomass production systems. 
In order to explain the apparently high variability in the water demand of SRCs, a range of determinants affecting the evapotranspiration components of the water balance equation is worth considering. A literature overview of evapotranspiration rates provided by Busch (2009) shows that plantations with a dense and closed canopy of high leaf area display higher evapotranspiration rates than plantations in an early phase of stand development, with lower leaf area and a more open canopy. Consequently, management schemes with shorter rotation periods, where trees are cut before developing a dense canopy, appear to reduce evapotranspiration, and respectively potentially increase groundwater recharge at the plot scale. In younger plantations, $E_{t}$ and $E_{i}$ might be reduced on the one hand due to effectively lower plant surfaces transpiring water and intercepting rainfall. On the other hand, $\mathrm{E}_{\mathrm{s}}$ and the transpiration of understorey vegetation might be increased, due to a higher amount of available energy below a more open canopy. As well, transpiration per leaf area might be increased, due to a better ventilation of the canopy and a higher coupling to atmospheric water demand (Lindroth et al., 1994), which might compensate for a lower area of transpiring plant surfaces. Most field studies on SRC water use however were conducted in full-grown plantations, or do not particularly address the developmental stage of the investigated plantation, and there is a lack of reports explicitly addressing the water use of young SRCs, characterized by a low leaf area and an open canopy.

Another factor that potentially contributed to the diversity of reported results on SRC water use might be the large number of different poplar and willow hybrids of the studied plantations. Especially poplar hybrids are known to display a wide range of physiological mechanisms to regulate transpiration in response to environmental variables. In general, poplars are considered as drought-avoiding, isohydric tree species that efficiently control transpiration by stomatal regulation of gas exchange in response to low air humidity and soil drought (Tardieu and Simonneau, 1998). This conservative, water-saving strategy might result in comparatively low crop coefficients at the field scale even when water supply is ample, because transpiration is limited at high vapour pressure deficits (D), while $\mathrm{ET}_{0}$ is not. However, this water use strategy may not be displayed by all poplar hybrids, as a more drought-tolerant anisohydric behaviour is also reported from greenhouse experiments (Larchevêque et al., 2011). Anisohydric behaviour is characterised by loose stomatal control of transpiration and dropping leaf water potentials under moderate drought. This allows for a sustained gas exchange and hence photosynthetic activity and biomass production, but would also result in higher crop coefficients at high $\mathrm{D}$ and therefore can be a reason for the relative differences in SRC water demand. Although the variability in water use strategies was shown 
for potted poplar plants, there is indication that such anisohydric strategy can actually be observed at the field scale. E.g., Hall et al. (1998) observed high stomatal conductance in a poplar SRC in England, even when D was large. This points to an anisohydric water use strategy, and in this specific case caused extraordinarily high transpiration rates, while isohydric poplar hybrids might have displayed a less profligate water use under the same conditions. However, water use strategies had not been addressed at the canopy level in European poplar hybrids, when this dissertation was initiated, but have implications on productivity and water use of individual poplar hybrids growing under individual pedoclimatic conditions. Therefore, information on the individual water use behaviour of poplar hybrids would help to select adequate plant material for specific sites, under consideration of water management aspects.

\subsection{Objectives}

The aims of this dissertation were to evaluate the environmental impacts of SRC cultivation, and to provide information on SRC water use at the field scale for developing adaptive, sustainable management strategies for woody biomass production systems. To attain these aims, seepage nitrate concentrations and water use of several SRCs were determined, and factors being amenable to management were evaluated for their potential to reduce SRC evapotranspiration and increase groundwater recharge at the field scale. Within this context, this thesis contributes to the understanding of environmental impacts of SRC cultivation by framing the following objectives:

1. Evaluate the water balance of SRCs, and relate the results to the water balance of other land use forms and reference evaporation (Chapters 2-4).

2. Compare SRC evapotranspiration measured in an early phase of stand development to the water use of a full-grown, mature plantation with a dense canopy and high leaf area (Chapter 3).

3. Characterise the water use strategy of different poplar hybrids (Chapter 3).

4. Assess the environmental impacts of SRC cultivation in the Fuhrberger Feld with respect to the requirements of groundwater protection (Chapter 5). 
The following hypotheses guided the work:

I. Evapotranspiration of SRCs is higher than evapotranspiration of deciduous forests.

II. Evapotranspiration of young SRCs is lower than evapotranspiration of mature SRCs.

III. The water use strategy of the investigated poplar hybrids is isohydric.

\subsection{Approach and study sites}

The objectives were addressed by carrying out own field work (2009-2012) in the drinking water abstraction area Fuhrberger Feld near Hanover, Germany (Figure 1-1, Table 1-1). Field work was carried out in two poplar ("P09", "P94", planted 2009 and 1994) and two willow SRCs ("W05", "W94", planted in 2005 and 1994), and one former arable field ("Ref", set aside in the 1990s) for groundwater protection reasons, and now resembles unmanaged grassland vegetation. The data from the Fuhrberger Feld were complemented by two external datasets obtained from SRCs located in Großfahner (Thuringia) and Kaufering (Bavaria). Both external datasets were obtained from full-grown, mature plantations of modern poplar hybrids with high leaf area, which were lacking in the study area Fuhrberger Feld when the field work was conducted.

The objectives 1 and 4 were addressed by conducting field observations in the Fuhrberger Feld, comprising soil water tension, element concentrations in seepage water, and soil physical and chemical properties in all four SRCs in and the former arable field. In all SRCs, leaf area index (LAI) was measured and in selected years and sites, stand precipitation was determined. The water balance components including groundwater recharge were determined for the willow plot W05 and the former arable field Ref from process-based simulations using the Coupmodel (Jansson and Karlberg, 2004). The model was used in a forward modelling approach, i.e. the simulations were parameterised with collected data on soil physical properties and LAI, and validated with data on stand precipitation and soil water tension. Model parameters that could not be measured were derived from the literature, and some manual adjustments of single model parameters were made.

Objective 1 was additionally addressed by complementing the evaluation of the SRC water balance in the Fuhrberger Feld with the water balance of a poplar SRC (hybrid "Max 3", P. nigra $\times$ P. maximowiczii) located in a second drinking water abstraction area with contrasting soil and climate conditions at Kaufering near Munich. There, volumetric soil water contents and meteorological data were measured and provided by Martina Zacios from 
the Bavarian State Institute of Forestry (project "Ökologische und ertragskundliche Aspekte von Kurzumtriebsplantagen bei Kaufering - KLIP11”). The observations of soil water content were used to derive soil water storage for a soil depth of $0-200 \mathrm{~cm}$, to which the processbased hydrological model LWF-Brook90 (Hammel and Kennel, 2001) was calibrated using an inverse modelling approach, after the important parameters for model fit were identified by a sensitivity analysis. The calibration was conducted using the Differential Evolution Markov chain Monte Carlo (DEzs) algorithm (ter Braak and Vrugt, 2008). From the calibrated model, the water balance components and their uncertainty bounds were derived. The modelling approach and results are presented as a case study in Chapter 4, which describes a newly developed extension package ( $\mathrm{LWFBrook90R}$ ) for the $\mathrm{R}$ language and environment for statistical computing (R Core Team, 2019).

To address objectives 2 and 3, evapotranspiration was measured in 2011 using the Bowen Ratio Energy Balance (BREB) method in the young poplar plantation P09 in the Fuhrberger Feld, which was planted in early spring 2009 using cuttings of different poplar hybrids ("Max 3", Populus nigra $\times$ P. maximowiczii; "Androscoggin", P. maximowiczii $\times P$. trichocarpa; "AF2" P. deltoides $\times$ P. nigra) and in 2011 approached canopy closure. This dataset was compared to stand transpiration data of a mature poplar SRC with a high leaf area ("J-105", P. nigra $\times$ P. maximowiczii), derived from sap flux measurements conducted in 2012 by Dr. Falk Richter within the project BEST ("Bioenergie-Regionen stärken") in Großfahner (Thuringia). The water use strategy was inferred from evaluating the response of canopy conductance $\left(\mathrm{g}_{\mathrm{c}}\right.$, derived from $\mathrm{E}_{\mathrm{t}}$ ) to $\mathrm{D}$ with respect to a theoretical response for isohydric behaviour (Oren et al., 1999). The results of the comparison and the assessment of the water use behaviour are presented in Chapter 3. 


\begin{tabular}{|c|c|c|c|}
\hline & Fuhrberger Feld & Großfahner & Kaufering \\
\hline Location & $52^{\circ} 35^{\prime} \mathrm{N}, 9^{\circ} 49^{\prime} \mathrm{E}$ & $51^{\circ} 30^{\prime} \mathrm{N}, 10^{\circ} 49^{\prime} \mathrm{E}$ & $48^{\circ} 05^{\prime} \mathrm{N}, 10^{\circ} 51^{\prime} \mathrm{E}$ \\
\hline Elevation (m) & 37 & 189 & 620 \\
\hline $\begin{array}{l}\text { Mean annual temperature } \\
\text { and rainfall }\left({ }^{\circ} \mathrm{C}, \mathrm{mm}\right)\end{array}$ & $8.9,677$ & $9.4,549$ & $8.4,994$ \\
\hline Size (ha) & 3.5 & 0.6 & 2.5 \\
\hline Cultivated poplar hybrids & $\begin{array}{l}\text { "Max 1", "Androscoggin", } \\
\text { "AF2", "Tora" (willow) }\end{array}$ & "Japan J-105" & "Max 1" \\
\hline Actual plant density $\left(\mathrm{N} \mathrm{ha}^{-1}\right)$ & 12750 & 9454 & 9454 \\
\hline Soil texture & sand / loamy sand & silt loam & silt loam \\
\hline $\begin{array}{l}\text { Plant available water } \\
\text { capacity } 0-100 \mathrm{~cm}(\mathrm{~mm})\end{array}$ & 160 & 205 & 256 \\
\hline Groundwater level (m) & $3.8-4.5$ & $1.8-2.7$ & 6 \\
\hline Shoot age / stand age (years) & $2 / 2$ & $5 / 5$ & $4 / 4$ \\
\hline Stand height (m) & 2.5 & 9.5 & 10 \\
\hline $\begin{array}{l}\text { Maximum leaf area index } \\
\left(\mathrm{m}^{2} \mathrm{~m}^{-2}\right)\end{array}$ & 3.8 & 7.4 & 6.5 \\
\hline
\end{tabular}

Table 1-1: Basic information on the study sites 

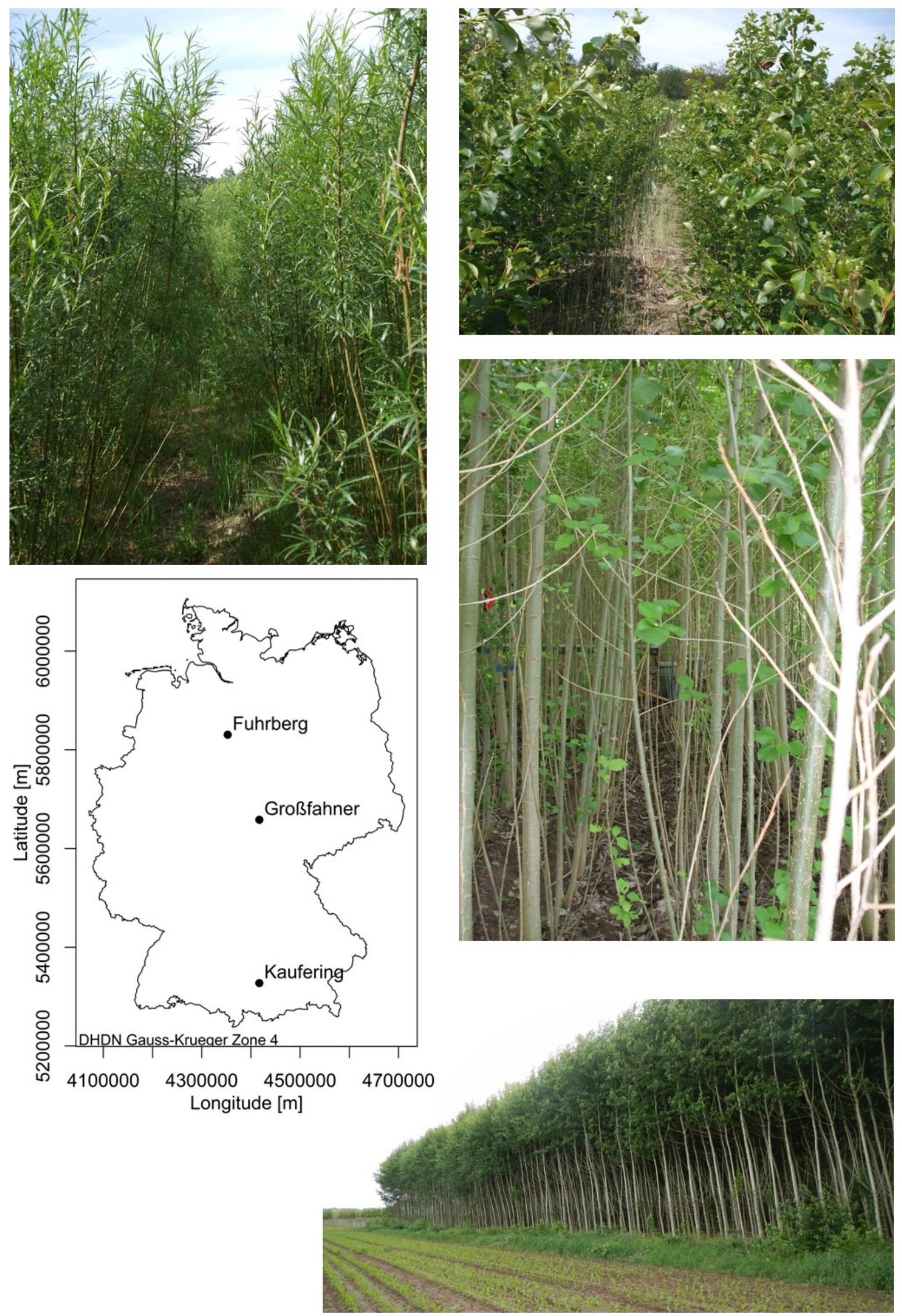

Figure 1-1 Study sites and individual SRC study plots. Fuhrberg: W05 (top left, 2011, "Tora”), P09 (top right, 2011, "Max 3”); Großfahner (mid right, 2012, “J-105”); Kaufering (bottom right, 2011, “Max 1”) 


\section{References}

Allen, R.G., Pereira, L.S., Raes, D., Smith, M., 1998. Crop evapotranspiration: guidelines for computing crop water requirements (No. 56), FAO Irrigation and drainage papers. FAO, Rome.

Aronsson, P.G., Bergström, L.F., Elowson, S.N.E., 2000. Long-term influence of intensively cultured short-rotation Willow Coppice on nitrogen concentrations in groundwater. J. Environ. Manage. 58, 135-145. https://doi.org/10.1006/jema.1999.0319

BMELV (Ed.), 2011. Forest Strategy 2020. Federal Ministry of Food, Agriculture and Consumer Protection (BMELV).

Bredemeier, M., Busch, G., Hartmann, L., Jansen, M., Richter, F., Lamersdorf, N.P., 2015. Fast growing plantations for wood production - integration of ecological effects and economic perspectives. Plant Biotechnol. 72. https://doi.org/10.3389/fbioe.2015.00072

Bungart, R., Hüttl, R.F., 2004. Growth dynamics and biomass accumulation of 8-year-old hybrid poplar clones in a short-rotation plantation on a clayey-sandy mining substrate with respect to plant nutrition and water budget. Eur. J. For. Res. 123, 105-115. https://doi.org/10.1007/s10342-004-0024-8

Busch, G., 2009. The impact of Short Rotation Coppice cultivation on groundwater recharge a spatial (planning) perspective. Landbauforsch. - VTI Agric. For. Res. 3593 (59), 207-222.

DBFZ, 2015. Schnellwachsende Baumarten in Deutschland und deren Einsatz zur Wärmebereitstellung. Deutsches Biomasseforschungszentrum (DBFZ), Leipzig.

Dickmann, D.I., 2006. Silviculture and biology of short-rotation woody crops in temperate regions: Then and now. Biomass Bioenergy 30, 696-705. https://doi.org/10.1016/j.biombioe.2005.02.008

Dimitriou, I., Aronsson, P., 2011. Wastewater and sewage sludge application to willows and poplars grown in lysimeters-Plant response and treatment efficiency. Biomass Bioenergy 35, 161-170. https://doi.org/10.1016/j.biombioe.2010.08.019

Dimitriou, I., Aronsson, P., 2004. Nitrogen leaching from short-rotation willow coppice after intensive irrigation with wastewater. Biomass Bioenergy 26, 433-441. https://doi.org/10.1016/j.biombioe.2003.08.009

Dimitriou, I., Mola-Yudego, B., 2017. Poplar and willow plantations on agricultural land in Sweden: Area, yield, groundwater quality and soil organic carbon. For. Ecol. Manag., Sustainability of increased forest biomass harvest from a Swedish perspective 383, 99-107. https://doi.org/10.1016/j.foreco.2016.08.022

Dimitriou, I., Mola-Yudego, B., Aronsson, P., 2012. Impact of Willow Short Rotation Coppice on Water Quality. BioEnergy Res. 5, 537-545. https://doi.org/10.1007/s12155-012-9211-5

Don, A., Osborne, B., Hastings, A., Skiba, U., Carter, M.S., Drewer, J., Flessa, H., Freibauer, A., Hyvönen, N., Jones, M.B., Lanigan, G.J., Mander, Ü., Monti, A., Djomo, S.N., Valentine, J., Walter, K., Zegada-Lizarazu, W., Zenone, T., 2012. Land-use change to bioenergy production in Europe: implications for the greenhouse gas balance and soil carbon. GCB Bioenergy 4, 372-391. https://doi.org/10.1111/j.17571707.2011.01116.x

Drew, A.P., Zsuffa, L., Mitchell, C.P., 1987. Termonilogy relating to woody plant biomass and its production. Biomass 12, 79-82. https://doi.org/10.1016/0144-4565(87)90010-2

Drewer, J., Finch, J.W., Lloyd, C.R., Baggs, E.M., Skiba, U., 2012. How do soil emissions of $\mathrm{N} 2 \mathrm{O}, \mathrm{CH} 4$ and $\mathrm{CO} 2$ from perennial bioenergy crops differ from arable annual crops? GCB Bioenergy 4, 408-419. https://doi.org/10.1111/j.1757-1707.2011.01136.x

EEA, 2006. How much bioenergy can Europe produce without harming the environment? European Environment Agency, Copenhagen, Denmark. 
Finch, J.W., Hall, R.L., Rosier, P.T.W., Clark, D.B., Stratford, C., Davies, H.N., Marsh, T.J., Roberts, J.M., Riche, A., Christian, D., 2004. The hydrological impacts of energy crop production in the UK. Final Report. (Publication - Report). UK, Department of Trade and Industry.

Fischer, M., Trnka, M., Kučera, J., Deckmyn, G., Orság, M., Sedlák, P., Žalud, Z., Ceulemans, R., 2013. Evapotranspiration of a high-density poplar stand in comparison with a reference grass cover in the Czech-Moravian Highlands. Agric. For. Meteorol. 181, 43-60. https://doi.org/10.1016/j.agrformet.2013.07.004

Fischer, M., Zenone, T., Trnka, M., Orság, M., Montagnani, L., Ward, E.J., Tripathi, A.M., Hlavinka, P., Seufert, G., Žalud, Z., King, J.S., Ceulemans, R., 2018. Water requirements of short rotation poplar coppice: Experimental and modelling analyses across Europe. Agric. For. Meteorol. 250-251, 343-360. https://doi.org/10.1016/j.agrformet.2017.12.079

Gelfand, I., Sahajpal, R., Zhang, X., Izaurralde, R.C., Gross, K.L., Robertson, G.P., 2013. Sustainable bioenergy production from marginal lands in the US Midwest. Nature 493, 514-517. https://doi.org/10.1038/nature11811

Goodlass, G., Green, M., Hilton, B., McDonough, S., 2007. Nitrate leaching from shortrotation coppice. Soil Use Manag. 23, 178-184. https://doi.org/doi:10.1111/j.14752743.2006.00080.x

Hall, R.L., Allen, S.J., Rosier, P.T.W., Hopkins, R., 1998. Transpiration from coppiced poplar and willow measured using sap-flow methods. Agric. For. Meteorol. 90, 275-290.

Hall, R.L., Allen, S.J., Rosier, P.T.W., Smith, D.M., Hodnett, G., Roberts, J.M., Hopkins, R., Davies, H.N., 1996. Hydrological effects of short rotation energy coppice. Final report to ETSU. Institute of Hydrology, Wallingford.

Hammel, K., Kennel, M., 2001. Charakterisierung und Analyse der Wasserverfügbarkeit und des Wasserhaushalts von Waldstandorten in Bayern mit dem Simulationsmodell BROOK90, Forstliche Forschungsberichte München.

Heilmann, B., Makeschin, F., Rehfuess, K.E., 1995. Vegetationskundliche Untersuchungen auf einer Schnellwuchsplantage mit Pappeln und Weiden nach Ackernutzung. Forstwiss. Cent. Ver. Mit Tharandter Forstl. Jahrb. 114, 16-29. https://doi.org/10.1007/BF02742208

Hellebrand, H., Strähle, M., Scholz, V., Kern, J., 2010. Soil carbon, soil nitrate, and soil emissions of nitrous oxide during cultivation of energy crops. Nutr. Cycl. Agroecosystems 87, 175-186. https://doi.org/10.1007/s10705-009-9326-z

Holder, A.J., Rowe, R., McNamara, N.P., Donnison, I.S., McCalmont, J.P., 2019. Soil Water Assessment Tool (SWAT) simulated hydrological impacts of land use change from temperate grassland to energy crops: a case study in western UK. GCB Bioenergy 0. https://doi.org/10.1111/gcbb.12628

Jansson, P.-E., Karlberg, L., 2004. Coupled heat and mass transfer model for soil-plantatmosphere systems. Royal Institute of Technolgy, Dept of Civil and Environmental Engineering Stockholm, Stockholm.

Jug, A., Hofmann-Schielle, C., Makeschin, F., Rehfuess, K.E., 1999a. Short-rotation plantations of balsam poplars, aspen and willows on former arable land in the Federal Republic of Germany. II. Nutritional status and bioelement export by harvested shoot axes. For. Ecol. Manag. 121, 67-83. https://doi.org/10.1016/S0378-1127(98)00557-X

Jug, A., Makeschin, F., Rehfuess, K.E., Hofmann-Schielle, C., 1999b. Short-rotation plantations of balsam poplars, aspen and willows on former arable land in the Federal Republic of Germany. III. Soil ecological effects. For. Ecol. Manag. 121, 85-99. https://doi.org/10.1016/S0378-1127(98)00558-1 
Kern, J., Hellebrand, H.J., Scholz, V., Linke, B., 2010. Assessment of nitrogen fertilization for the $\mathrm{CO} 2$ balance during the production of poplar and rye. Renew. Sustain. Energy Rev. 14, 1453-1460. https://doi.org/10.1016/j.rser.2010.01.011

Köhler, K., Duijnisveld, W.H.M., Böttcher, J., 2006. Nitrogen fertilization and nitrate leaching into groundwater on arable sandy soils. J. Plant Nutr. Soil Sci. 169, 185-195.

Lamersdorf, N., Petzold, R., Schwärzel, K., Feger, K.-H., Köstner, B., Moderow, U., Bernhofer, C., Knust, C., 2010. Bodenökologische Aspekte von Kurzumtriebsplantagen, in: Bemmann, A., Knust, C. (Eds.), Agrowood Kurzumtriebsplantagen in Deutschland Und Europäische Perspektiven. Weißensee Verlag, pp. 170-188.

Larchevêque, M., Maurel, M., Desrochers, A., Larocque, G.R., 2011. How does drought tolerance compare between two improved hybrids of balsam poplar and an unimproved native species? Tree Physiol. 31, 240-249. https://doi.org/10.1093/treephys/tpr011

Lasch, P., Kollas, C., Rock, J., Suckow, F., 2010. Potentials and impacts of short-rotation coppice plantation with aspen in Eastern Germany under conditions of climate change. Reg. Environ. Change 10, 83-94. https://doi.org/10.1007/s10113-009-0095-7

Lindegaard, K.N., Adams, P.W.R., Holley, M., Lamley, A., Henriksson, A., Larsson, S., von Engelbrechten, H., Esteban Lopez, G., Pisarek, M., 2016. Short rotation plantations policy history in Europe: lessons from the past and recommendations for the future. Food Energy Secur. 5, 125-152. https://doi.org/10.1002/fes3.86

Linderson, M.-L., Iritz, Z., Lindroth, A., 2007. The effect of water availability on stand-level productivity, transpiration, water use efficiency and radiation use efficiency of fieldgrown willow clones. Biomass Bioenergy 31, 460-468. https://doi.org/10.1016/j.biombioe.2007.01.014

Lindroth, A., Båth, A., 1999. Assessment of regional willow coppice yield in Sweden on basis of water availability. For. Ecol. Manag. 121, 57-65. https://doi.org/10.1016/S03781127(98)00556-8

Lindroth, A., Verwijst, T., Halldin, S., 1994. Water-use efficiency of willow: Variation with season, humidity and biomass allocation. J. Hydrol. 156, 1-19. https://doi.org/10.1016/0022-1694(94)90068-X

Makeschin, F., 1994. Effects of energy forestry on soils. Biomass Bioenergy, Environmental Aspects of Energy Forest Cultivation 6, 63-79. https://doi.org/10.1016/09619534(94)90086-8

Meiresonne, L., Schrijver, A.D., Vos, B.D., 2007. Nutrient cycling in a poplar plantation (Populus trichocarpa $\times$ Populus deltoides 'Beaupré') on former agricultural land in northern Belgium. Can. J. For. Res. 37, 141-155. https://doi.org/10.1139/x06-205

Nitsch, J., 2008. Weiterentwicklung der Ausbaustrategie Erneuerbare Energien Leitstudie 2008. Bundesministerium für Umwelt, Naturschutz und Reaktorsicherheit (BMU).

Njakou Djomo, S., Kasmioui, O.E., Ceulemans, R., 2011. Energy and greenhouse gas balance of bioenergy production from poplar and willow: a review. GCB Bioenergy 3, 181197. https://doi.org/10.1111/j.1757-1707.2010.01073.x

Oren, R., Sperry, J.S., Katul, G.G., Pataki, D.E., Ewers, B.E., Phillips, N., Schäfer, K.V.R., 1999. Survey and synthesis of intra- and interspecific variation in stomatal sensitivity to vapour pressure deficit. Plant Cell Environ. 22, 1515-1526. https://doi.org/10.1046/j.1365-3040.1999.00513.x

Perry, C.H., Miller, R.C., Brooks, K.N., 2001. Impacts of short-rotation hybrid poplar plantations on regional water yield. For. Ecol. Manag., Special Issue: THE SCIENCE OF MANAGING FORESTS TO SUSTAIN 143, 143-151. https://doi.org/10.1016/S0378-1127(00)00513-2 
Persson, G., 1997. Comparison of Simulated Water Balance for Willow, Spruce, Grass Ley, and Barley. Nord. Hydrol. 28, 85-89.

Persson, G., Lindroth, A., 1994. Simulating evaporation from short-rotation forest: variations within and between seasons. J. Hydrol. 156, 21-45. https://doi.org/10.1016/00221694(94)90069-8

Petzold, R., Feger, K.-H., Schwärzel, K., 2009. Wasserhaushalt von Kurzumtriebsplantagen, in: Anbau und Nutzung von Bäumen auf Landwirtschaftlichen Flächen. John Wiley \& Sons, Ltd, pp. 181-191. https://doi.org/10.1002/9783527627462.ch16

Petzold, R., Schubert, B., Feger, K.-H., 2010. Biomasseproduktion, Nährstoffallokation und bodenökologische Veränderungen einer Pappel-Kurzumtriebsplantage in Sachsen. Bodenkult. 61, 23-35.

Petzold, R., Schwärzel, K., Feger, K.-H., 2011. Transpiration of a hybrid poplar plantation in Saxony (Germany) in response to climate and soil conditions. Eur. J. For. Res. 130, 695-706. https://doi.org/10.1007/s10342-010-0459-z

Quirin, M., Hoetmer, M., Hartung, T., 2017. Wirkung des Niedersächsischen Kooperationsmodells zum Trinkwasserschutz, in: Porth, M., Schüttrumpf, H. (Eds.), Wasser, Energie und Umwelt: Aktuelle Beiträge aus der Zeitschrift Wasser und Abfall I. Springer Fachmedien Wiesbaden, Wiesbaden, pp. 247-255. https://doi.org/10.1007/978-3-658-15922-1_32

R Core Team, 2019. R: A Language and Environment for Statistical Computing. R Foundation for Statistical Computing, Vienna, Austria.

Robertson, G.P., Paul, E.A., Harwood, R.R., 2000. Greenhouse Gases in Intensive Agriculture: Contributions of Individual Gases to the Radiative Forcing of the Atmosphere. Science 289, 1922-1925. https://doi.org/10.1126/science.289.5486.1922

Springob, G., Brinkmann, S., Engel, N., Kirchmann, H., J, B., 2001. Organic C levels of Ap horizons in north german pleistocene sands as influenced by climate, texture, and history of land-use. J. Plant Nutr. Soil Sci. 164, 681-690.

Stephens, W., Hess, T., J, K., 2001. Review of the effects of energy crops on hydrology. Cranfield University.

Tardieu, F., Simonneau, T., 1998. Variability among species of stomatal control under fluctuating soil water status and evaporative demand: modelling isohydric and anisohydric behaviours. J. Exp. Bot. 49, 419-432. https://doi.org/10.1093/jxb/49.Special_Issue.419

ter Braak, C.J.F., Vrugt, J.A., 2008. Differential Evolution Markov Chain with snooker updater and fewer chains. Stat. Comput. 18, 435-446. https://doi.org/10.1007/s11222008-9104-9

Thrän, D., Edel, M., Seidenberger, T., 2009. Identifizierung strategischer Hemmnisse und Entwicklung von Lösungsansätzen zur Reduzierung der Nutzungskonkurrenzen beim weiteren Ausbau der energetischen Biomassenutzung. 1. Zwischenbericht. Deutsches Biomasseforschungszentrum (DBFZ).

Verwijst, T., Lundkvist, A., Edelfeldt, S., Albertsson, J., 2013. Development of Sustainable Willow Short Rotation Forestry in Northern Europe. Biomass - Sustain. Growth Use. https://doi.org/10.5772/55072

Wahren, A., Schwärzel, K., Feger, K.-H., 2012. Potentials and limitations of natural flood retention by forested land in headwater catchments: evidence from experimental and model studies. J. Flood Risk Manag. 5, 321-335. https://doi.org/10.1111/j.1753318X.2012.01152.x

Zalesny, R.S., Wiese, A.H., Bauer, E.O., Riemenschneider, D.E., 2006. Sapflow of hybrid poplar (Populus nigra L. $\times$ P. maximowiczii A. Henry 'NM6') during phytoremediation of landfill leachate. Biomass Bioenergy 30, 784-793. https://doi.org/10.1016/j.biombioe.2005.08.006 
Zenone, T., Fischer, M., Arriga, N., Broeckx, L.S., Verlinden, M.S., Vanbeveren, S., Zona, D., Ceulemans, R., 2015. Biophysical drivers of the carbon dioxide, water vapor, and energy exchanges of a short-rotation poplar coppice. Agric. For. Meteorol. 209-210, 22-35. https://doi.org/10.1016/j.agrformet.2015.04.009 


\section{Chapter 2}

Biomass Production with Willow and Poplar Short Rotation

Coppices on Sensitive Areas-the Impact on Nitrate Leaching and Groundwater Recharge in a Drinking Water Catchment near Hanover, Germany

Paul Schmidt-Walter \& Norbert Lamersdorf

Published Journal Article, Bioenergy Research (2012) 5:546-562

https://doi.org/10.1007/s12155-012-9237-8 


\title{
Biomass Production with Willow and Poplar Short Rotation Coppices on Sensitive Areas- the Impact on Nitrate Leaching and Groundwater Recharge in a Drinking Water Catchment near Hanover, Germany
}

\author{
Paul Schmidt-Walter • \\ Norbert P. Lamersdorf \\ C The Author(s) 2012. This article is published with open access at Springerlink.com
}

\begin{abstract}
In a lowland drinking water catchment area, nitrate leaching as well as groundwater recharge (GWR) was investigated in willow and poplar short rotation coppice (SRC) plantations of different ages, soil preparation measures prior to planting and harvesting intervals. Significantly increased nitrate concentrations of $16.6 \pm 1.6 \mathrm{mg} \mathrm{NO}_{3}-\mathrm{N} \mathrm{L}^{-1}$ were measured in winter/spring 2010 on a poplar site, established in 2009 after deep plowing $(90 \mathrm{~cm})$ but then, subsequently decreased strongly to below $2 \mathrm{mg} \mathrm{NO}_{3}-\mathrm{N} \mathrm{L}^{-1}$ in spring 2011. The fallow ground reference plot showed nitrate concentrations consistently below $1 \mathrm{mg} \mathrm{L}^{-1}$ and estimated annual seepage output loss was only $1.36 \pm 1.1 \mathrm{~kg} \mathrm{ha}^{-1} \mathrm{a}^{-1}$. Leaching loss from a neighboring willow plot from 2005 was $14.3 \pm$ $6.6 \mathrm{~kg} \mathrm{NO}_{3}-\mathrm{N} \mathrm{ha}^{-1}$ during spring 2010 but decreased to $2.0 \pm$ $1.5 \mathrm{~kg} \mathrm{NO}_{3}-\mathrm{N} \mathrm{ha}^{-1}$ during the subsequent drainage period. A second willow plot, not harvested since its establishment in 1994, showed continuously higher nitrate concentrations $\left(10.2 \pm 1.7 \mathrm{NO}_{3}-\mathrm{N} \mathrm{L}^{-1}\right)$, while a neighboring poplar plot, twice harvested since 1994 showed significantly reduced nitrate concentrations. Water balance simulations, referenced by soil water tension and throughfall measurements, showed that at $655 \mathrm{~mm}$ annual rainfall, GWR from the reference plot $\left(300 \mathrm{~mm} \mathrm{a}^{-1}\right.$ ) was reduced by $40 \%$ (to $180 \mathrm{~mm} \mathrm{a}^{-1}$ ) on the 2005 willow stand, mainly due to doubled rainfall interception losses. However, transpiration was limited by low soil water storage capacities, which in turn led to a moderate impact on GWR. We conclude that well-managed SRC on sensitive areas can prevent nitrate leaching, while impacts on GWR may be mitigated by management options.
\end{abstract}

P. Schmidt-Walter $(\square) \cdot$ N. P. Lamersdorf

Büsgen-Institute, Soil Science of Temperate Ecosystems,

Georg-August-Universität Göttingen,

Büsgenweg 2,

37077 Göttingen, Germany

e-mail: pschmid1@gwdg.de
Keywords SRC · Groundwater quality $\cdot$ Sandy soil · Evapotranspiration · Leaf area index

\section{Introduction}

To combat climate change and improve security of energy supply, bioenergy derived from forestry and agriculture plays a key role in the European Union (EU). Bioenergy production has almost doubled in production in the last 15 years and currently supplies $7 \%$ of the total EU primary energy [1]. According to the binding targets set by the EU Renewable Energy Directive (RED), all Member States should strive to a $20 \%$ share of renewable energy by 2020. Furthermore, it is required that EU member states achieve at least a $10 \%$ share of renewable energy (biofuel) of the total gasoline and diesel consumed in the transport sector by the year 2020 [2].

Bioenergy crops from agriculture provide the largest potential to fulfill those EU targets. An assessment made by the European Environment Agency found that about $85 \%$ of the potential bioenergy supply can be produced by only seven member states (Spain, France, Germany, Italy, UK, Lithuania and Poland; [3]). To achieve these goals, approximately 17.5 million ha of land will have to be dedicated to the production of energy crops by 2020 [4]. Thus, an additional pressure on farmland biodiversity as well as on soil and water resources can be expected in biofuel production regions in the EU.

In Germany, approximately 2.3 million ha or $19 \%$ of the crop land is already being used for the production of renewable raw materials [5]. Compared to 2001, the area has almost tripled and in 2011 the largest proportion of about 2 million ha fell to the energy plant production with a share of $46 \%$ for biodiesel (mainly canola), $41 \%$ for biogas 
(mainly maize) and $13 \%$ for the production of bioethanol. Although perennial energy crops like short rotation coppices (SRC) with fast-growing trees have played only a minor role in bioenergy production, the total cultivated area for SRC increased from about 4,000 ha in 2010 to about 5,000 ha in just 1 year [5].

Nevertheless, SRC may provide unique ecological services that warrant consideration. As a result of lower fertilizer requirements as well as a higher $\mathrm{N}$-use efficiency due to effective N-recycling, SRC emit 40 to $>99 \%$ less $\mathrm{N}$ than conventional annual crops. Furthermore, SRC have the potential to sequester additional carbon $(0.44 \mathrm{Mg}$ soil $\mathrm{C} \mathrm{ha}^{-1}$ year $^{-1}$ ) in soils if established on former cropland [6]. According to Djomo et al. [7], SRC yielded about 14 86 times more energy than coal per unit of fossil energy input and greenhouse gas (GHG) emissions were 9-161 times lower than those of coal. Consequently, SRC provide an opportunity to reduce dependency on fossil fuels and to mitigate GHG emissions. Therefore, SRC should be part of an overall strategy for achieving the minimum target for GHG emissions reduction as required by the EU RED [7]. Additionally, SRC may also increase agricultural income diversification, enhance biodiversity, and reduce nutrient losses to the groundwater [6].

However, as the area requirements for bioenergy feedstock production increases, the pressure on marginal sites or fallow grounds with unfavorable site conditions may increase and SRC systems applied here may also have negative environmental impacts. Most importantly, it seems that SRC plots have to be optimally prepared by plowing to guarantee weed control during crop establishment [8-10]. Especially on fallow grounds, this may lead to an extra emission of $\mathrm{CO}_{2}$ and $\mathrm{N}_{2}$ O. According to Djomo et al. [7], these impacts depend on various factors such as the SRC cultivation practice, land management, site conditions, downstream processing and distribution routes. Furthermore, indirect impacts have to be considered. For instance, $\mathrm{N}_{2} \mathrm{O}$ emissions as a direct impact may be low on welldrained and well-aerated soils, but $\mathrm{NO}_{3}$ leaching may occur instead and contaminate adjacent water bodies [6, 11, 12].

Accordingly, the given study is focusing on such indirect emission effects, i.e., the risk of nitrate leaching during the establishment of SRC plantations, and the potential of nitrogen binding after the cultivation of SRC on fallow ground.

Our study site was located in the most important drinking water catchment area of the city of Hanover, Germany ("Fuhrberger Feld"). Here, much effort was spent by the water authorities during the last decades to keep the average seepage nitrate concentration on the catchment level below the legal drinking water threshold value of $10.3 \mathrm{mg} \mathrm{NO}_{3}-\mathrm{N} \mathrm{L}^{-1}$. Part of these efforts were voluntary agreements with resident farmers to reduce fertilizer applications to a minimum, but also many fields were set aside to lie fallow.
The enhanced nitrate concentrations in the seepage output of Fuhrberger Feld are linked to the prevailing periglacial and sandy soils in the area and the historical land use. With the formerly widespread heath plaggen fertilization process, high amounts of carbon were brought into the sandy soils [13]. In combination with originally high groundwater levels and pasture as predominant land use, high amounts of soil organic carbon accumulated in the topsoils of these areas. As long as these site conditions persisted (i.e., no changes in the water table or the grassland cover) those carbon stocks remained more or less stable. However, since the $1960 \mathrm{~s}$, a significant increase of the drinking water demand of the city of Hanover lowered the groundwater table considerably, with the result that the wet grassland fell dry. This lowering of the groundwater table and the subsequent transfer of grassland into intensively used arable land initiated a strong mineralization process, including the transfer of organic $\mathrm{N}$ to nitrate. According to model calculations of Springob et al. [14] and Springob and Kirchmann [15], it was estimated that it might take up to 100 years for the soils to achieve a new equilibrium under the present conditions. Under these conditions, Köhler et al. [16] concluded that the only way to reduce the $\mathrm{N}$ output to groundwater is to convert the arable land into forests or back into continuous grasslands, while setting aside the land will not reduce the risk of nitrate leaching in the long run. However, another promising land-use for fallow grounds to meet the requirements of groundwater protection might be the establishment of SRC with fast-growing trees like poplar or willow.

The desired positive effect of reducing nitrate leaching losses by SRC might come along with negative effects on groundwater quantity, as higher rates of transpiration and interception evaporation can be anticipated [17-24]. In a review [25], Dimitriou et al. summarized that groundwater recharge rates from SRC stands in general are expected to be lower when compared to arable fields or grassland in the same region. Moreover, there is indication that the amount of reduction beyond precipitation strongly depends on sitespecific conditions like soil type, occurrence of drought periods during the growing season and management practices such as the harvesting interval.

Biomass production by SRC might thus conflict with the assigned land use purpose in Fuhrberger Feld, i.e., to provide and guarantee adequate amounts of good quality drinking water for the city of Hanover.

Within this context, the objectives of our study were to evaluate the impact of SRC cultivation on (1) nitrate leaching losses and (2) groundwater recharge, by giving initial insights into basic soil background conditions, seepage nitrate concentrations and water budgets of four SRC stands (two willow and two poplar SRCs) in comparison with a fallow ground reference site. The studied SRC stands differ 
in stand age, soil preparation measures and harvesting regimes. Water balance components are calculated by applying a soil vegetation atmosphere transport model (CoupModel [26]) to the reference site and a willow SRC established in 2005. The simulations are parameterized with results from field measurements; the model performance is checked by observed soil water tensions and stand precipitation. Finally, we estimate nitrate seepage output rates by combining simulated drainage flux with measured nitrate concentrations. The following questions will be addressed: Is a change in land use from fallow ground to SRC associated with increased $\mathrm{N}$ leaching rates? Which factors control $\mathrm{N}$ leaching rates? Under present site conditions, does a probable reduction in groundwater recharge interfere with the production of drinking water? How do site and vegetation characteristics affect the water balance and what management options do we have to mitigate a negative impact on groundwater recharge?

\section{Material and Methods}

\section{Site and Research Plot Description}

The Fuhrberger Feld drinking water catchment is located in northwest Germany, approximately $30 \mathrm{~km}$ north of the city of Hanover and has a size of $308 \mathrm{~km}^{2}$. Within this catchment area, research plots are located northwest of the village Fuhrberg $\left(52^{\circ} 36^{\prime} \mathrm{N}, 9^{\circ} 51^{\prime} \mathrm{E}\right)$ in a level 2 drinking water sanctuary [27] at an elevation of $41 \mathrm{~m}$ asl. Average annual precipitation (1971-2000) is $670 \mathrm{~mm}$, of which $46 \%$ fall during the growing season (May-October) and the mean annual temperature is $9.2^{\circ} \mathrm{C}$.

Table 1 shows the basic site characteristics of the research plots. There are two older poplar and willow plots, planted in 1994 (P94/30 and W94/30), a younger willow plot from $2005(\mathrm{~W} 05 / 90)$ and a poplar plot from $2009(\mathrm{P} 09 / 90)$. A setaside fallow ground serves as reference site (Ref). Prior to planting, P94/30 and W94/30 were conventionally plowed to $30 \mathrm{~cm}$ soil depth. The former organic topsoil horizon ( $\mathrm{Ah}$ ) was changed to an Ap (plowed) horizon, while the rest of the horizon sequence remained unchanged and comparable to the reference site (Ref; $E=$ eluviation horizon due to Plaggen fertilization [13], Bv-rGo=typical cambisol horizon, including indications of relict (r) reduced and gleyic conditions (Gor, Gr) due to a former higher groundwater table, mixed with the $\mathrm{Cv}$ horizon).

Prior to SRC cultivation from cuttings, plots Ref, P09/90 and W05/90 were part of one single arable field, which was set aside for groundwater protection reasons in the early 1990s. The Ref plot is dominated by grasses and some scattered flowers, due to the long time of abandonment. Plots W05/90 and P09/90 were deeply plowed to a maximum soil depth of $90 \mathrm{~cm}$. As a result, the Ah layer and its seedbank, as found on Ref, was buried at a depth of 30 $60 \mathrm{~cm}(\mathrm{R} 2+\mathrm{E}$ horizon) and covered with sandy bedrock material (R1). The site preparation allowed willow cuttings a headstart over the competing grasslayer, which is now present in the field. In 2010, the tree mortality rate on W05/90 was $1.7 \%$ [28]. During the study period, several plots were harvested. In March 2010, W94/30 was coppiced for the first time since its establishment in 1994, in April 2011 W05/90 followed. P94/30 was cut in March 2011 for the second time after February 2006.

\section{Collection of Soil Solution and Soil Samples}

Field installations for soil solution sampling, the sampling process itself, inclusive storage, transport and pre-treatment of the soil solution before the laboratory analysis were in line with the ICP IM manual (2004) for soil water chemistry [29].

Accordingly, six suction lysimeters per plot (polyvinyl chloride (PVC) pipe, $95 \times 2 \mathrm{~cm}$, connected with a $P-80$ cup, $5 \times 2 \mathrm{~cm}$, CeramTec Ag, Marktredwitz, Germany) were installed in November 2009, below the main rooting zone in $100 \mathrm{~cm}$ soil depth. After predrilling with a slightly smaller auger than the suction cups, the lysimeters were pushed directly into the soil, without applying additional active filling material. Lysimeters were evenly distributed in and between the tree rows. The soil solution was gathered in evacuated (max. 0.6 bar) 1-L glass vials, each connected via buried PVC tubing to one suction lysimeter and placed in a buried cool box next to the lysimeter field. Following the ICP manual (2004), soil solution was sampled bi-weekly to monthly. For transport and storage, solution samples were transferred into 100-ml PVC bottles and immediately stored in dark and cool conditions with a maximum temperature of $4{ }^{\circ} \mathrm{C}$. As samples should be analyzed for all major anions and cations and to avoid any analytical interference, no preservative was added prior to the analysis, which was done within the following month after field sampling. Due to relatively dry soil conditions between June and November 2010, no soil solution could be extracted during this time.

Soil samples for physical and chemical analysis were taken from one soil pit per field plot. From each horizon, three single samples were taken to determine chemical properties. On the research plots that were chosen for water balance simulations (Ref, W05/90), volume intact soil samples were taken using steel cylinders $\left(100 \mathrm{~cm}^{3}\right)$ to determine soil physical properties of the soil horizons. At W05/90, five replicate samples in soil depths of 5, 15, 25, 35, 65 and $100 \mathrm{~cm}$ were taken, to account for the heterogeneous soil profile caused by soil preparation measures. At the more homogenous profile of Ref, three replicate samples in depth 15,45 and $100 \mathrm{~cm}$ depth were taken. 
Table 1 Basic site and soil type background conditions of the research plots in the Fuhrberger Feld $(\mathrm{SR} / \mathrm{DR}=\mathrm{single} / \mathrm{double}$ row; $2 / 0.8 \times 0.6 \mathrm{~m}=2 \mathrm{~m}$ between, $0.8 \mathrm{~m}$ within DR; $0.6 \mathrm{~m}$ within SR)

\begin{tabular}{|c|c|c|c|c|}
\hline Plot & $\begin{array}{l}\text { Genus } \\
\text { Clone } \\
\text { Plantation spacing } \\
\text { Age }(2011)\end{array}$ & Soil treatment before planting & $\begin{array}{l}\text { Soil type, soil horizon } \\
\text { sequence, depth }(\mathrm{cm})\end{array}$ & Harvesting interventions until 2011 \\
\hline $\mathrm{P} 09 / 90$ & $\begin{array}{l}\text { Poplar } \\
\text { Mixture of clone } \operatorname{Max}^{\mathrm{a}} 1-3 \\
\text { DR }(2 / 0.8 \times 0.8 \mathrm{~m})^{\mathrm{b}} \\
2\end{array}$ & $\begin{array}{l}\text { Deep-plowing up to } 90 \mathrm{~cm} \text { soil } \\
\text { depth with a double-blade } \\
\text { plowshare (i.e., transfer of } \\
\text { the humic top layer }(30 \mathrm{~cm}) \text { to } \\
\text { a depth of } 30-60 \mathrm{~cm})\end{array}$ & $\begin{array}{l}\text { Young Treposol } \\
\text { R1 }(0-30) \\
\text { R2+E }(30-60) \\
\text { rGor }(60-80) \\
\text { rGr }(>80)\end{array}$ & 0 \\
\hline $\mathrm{P} 94 / 30$ & $\begin{array}{l}\text { Poplar } \\
\text { Row mixture of } 18 \text { clones } \\
\text { SR }(0.5 \times 2 \mathrm{~m})^{\mathrm{b}} \\
17\end{array}$ & $\begin{array}{l}\text { Conventional plowing up } \\
\text { to } 30 \mathrm{~cm} \text { soil depth }\end{array}$ & $\begin{array}{l}\text { As Ref. } \\
\text { lAp }(0-30) \\
\text { E }(30-40) \\
\text { Bv-rGo }(40-80) \\
\text { Cv-rGor }(>80)\end{array}$ & 2 (winter $2005+$ spring 2011$)$ \\
\hline W05/90 & $\begin{array}{l}\text { Willow } \\
\text { Clone Tora }{ }^{\mathrm{a}} \\
\text { DR }(1.5 / 0.8 \times 0.6 \mathrm{~m})^{\mathrm{b}} \\
6\end{array}$ & as $\mathrm{P} 09 / 90$ & $\begin{array}{l}\text { Older Treposol } \\
\text { as Ref }\end{array}$ & 1 (spring 2011) \\
\hline $\mathrm{W} 94 / 30$ & $\begin{array}{l}\text { Willow } \\
\text { S. viminalis } \\
\text { DR }(1.5 / 0.9 \times 0.5 \mathrm{~m})^{\mathrm{b}} \\
17\end{array}$ & As $\mathrm{P} 94 / 30$ & As Ref & 1 (spring 2010) \\
\hline Ref & Grassland & $\begin{array}{l}\text { Abandoned cropland since the } \\
\text { early } 1990 \text { s, i.e., today covered } \\
\text { with a grass layer }\end{array}$ & $\begin{array}{l}\text { Plaggenesch-Cambisol } \\
\text { over Relictgley } \\
\text { Ah }(0-30) \\
\text { E }(30-40) \\
\text { Bv-rGo }(40-80) \\
\text { Cv-rGor }(>80)\end{array}$ & - \\
\hline
\end{tabular}

${ }^{a}$ Clone Max $=$ Populus nigra $\times$ P. maximovizcii; Clone Tora $=$ Salix schwerinii $\times S$. viminalis

${ }^{\mathrm{b}}$ Fuhrberger Feld

Laboratory Analysis

The $\mathrm{pH}$ was measured on dried $\left(40{ }^{\circ} \mathrm{C},>48 \mathrm{~h}\right)$ and sieved $(\leq 2 \mathrm{~mm})$ soil samples using a digital $\mathrm{pH} /$ conductivity meter at a soil to water ratio of 1:2.5 (WTW GmbH Weilheim, West Germany). Total organic carbon $\left(C_{\text {org }}\right)$ and total nitrogen $\left(N_{t}\right)$ from mineral soil samples was measured from dried $\left(40^{\circ} \mathrm{C}\right.$, $>48 \mathrm{~h}$ ) and grounded samples using a C-N analyzer, (CHN-ORapide, VarioEL, Elementar, Germany). Our detection limit for total $\mathrm{N}$ is $\leq 0.2 \mathrm{mg} \mathrm{g}^{-1}$ and for total $\mathrm{C} \leq 0.1 \mathrm{mg} \mathrm{g}^{-1}$. The $\mathrm{C} / \mathrm{N}$ ratio was calculated from the obtained $C_{\text {org }}$ to $N_{t}$ values.

The mineral $\mathrm{N}$ content $\left(\mathrm{N}_{\min }, \mathrm{NH}_{4}{ }^{+}+\mathrm{NO}_{3}{ }^{-}\right)$was detected after extraction with $0.5 \mathrm{M} \mathrm{K}_{2} \mathrm{SO}_{4} \cdot \mathrm{NH}_{4}{ }^{+}$and $\mathrm{NO}_{3}{ }^{-}$were determined by using continuous flow injection colorimetric (Cenco/Skalar Instruments, Breda, The Netherlands). $\mathrm{NH}_{4}{ }^{+}$ was determined using the Berthelot reaction method (Skalar Method 155-000), $\mathrm{NO}_{3}{ }^{-}$in the $\mathrm{K}_{2} \mathrm{SO}_{4}$-extract as well as in the soil solution was determined using the copper-cadmium reduction method (Skalar Method 461-00). Total dissolved nitrogen (TDN) in the $\mathrm{K}_{2} \mathrm{SO}_{4}$ extract was analyzed by the given nitrate method after $\mathrm{NH}_{4}{ }^{+}$and organic $\mathrm{N}$ compounds were converted by an alkaline persulphate and UV digestion to $\mathrm{NO}_{3}{ }^{-}$. Dissolved organic nitrogen $\left(N_{\text {org }}\right)$ was computed as: $N_{\text {org }}=\mathrm{TDN}-\left(\mathrm{NH}_{4}{ }^{+} \mathrm{N}+\mathrm{NO}_{3}{ }^{-} \mathrm{N}\right)$.

All soil water laboratory analyses were applied in line with the aforementioned ICP Manual (2004; here section 8, Data Quality Assurance and Management [29]) and soil solution nitrate analysis was cross-checked by the correlation of NO3$\mathrm{N}+\mathrm{NH} 4-\mathrm{N}$ to total $\mathrm{N}\left(R^{2}=0.985\right)$. Furthermore, quality control of our laboratory analysis are regularly applied by the integration of internal standards, replicate measurements and the contribution to external ring analysis (e.g., [30], Lab Code A56 [31] Lab No. 44).

Soil water retention characteristics were analyzed for the W05/90 and Ref using the soil cores placed on a pressure membrane apparatus. Volumetric water contents were determined at pressure heads of $\mathrm{pF} 1.0, \mathrm{pF} 1.5, \mathrm{pF} 1.8, \mathrm{pF} 2.0$, pF 2.3, pF 2.5, pF 3.0, pF 3.3, pF 3.5, pF 3.7 and pF 4.2. 
The grain size distribution of the fine soil was determined gravimetrically after oxidization of organic carbon using $\mathrm{H}_{2} \mathrm{O}_{2}$, destruction of binding components using $\mathrm{Na}$-dithionite, following the method of Atterberg [32].

\section{Meteorological Variables}

A climate station was set up on an open field approximately $150 \mathrm{~m}$ from the W05/90 plot and $200 \mathrm{~m}$ from the Ref plot, to collect meteorological data to be used as input variables for our water balance simulations. Sensors were mounted on a $10 \mathrm{~m}$ tall mast and read out by a datalogger (Dl2e, Delta-T Devices). Data were collected every $5 \mathrm{~s}$, then aggregated at 10-min intervals. We measured precipitation at $1 \mathrm{~m}$ height (tipping bucket $0.1 \mathrm{~mm}$, Thies Clima, Göttingen Germany), air temperature, relative humidity (both HMP45D, Vaisala, Vantaa, Finland), global radiation (SP Lite, Kipp \& Zonen, Delft, The Netherlands) at $2 \mathrm{~m}$ height and wind speed (cup anemometer, Thies Clima) at $10 \mathrm{~m}$ height. For the use as model input, the data were checked for plausibility and later aggregated to hourly values. Data gaps in the time series due to equipment failure were filled with values from two nearby monitoring stations run by the German Weather Service. Precipitation values originate from a station about $4 \mathrm{~km}$ west of the field plots, while wind speed, relative humidity, air temperature and global radiation were taken from a station $15 \mathrm{~km}$ southwest from the field plots. Relative humidity and windspeed were adjusted to our site conditions by scaling daily mean values using linear relationships between our measurements and station data.

In 2010, precipitation was $651 \mathrm{~mm}$, with $351 \mathrm{~mm}$ falling during the growing season (May-October). The annual sum for 2011 was $662 \mathrm{~mm}$, of which $409 \mathrm{~mm}$ fell during the growing season. In 2010, a drought occurred in June and July, followed by a very wet period in August and September. The year 2011 was characterized by a cool and moist summer and a very dry and warm autumn.

\section{Measurements of Soil Water Tension and Stand} Precipitation

Soil water tensions to evaluate the simulation model performance were measured on the Ref and W05/90 plots at depths of $30 \mathrm{~cm}(n=3), 60 \mathrm{~cm}(n=3)$ and $100 \mathrm{~cm}(n=10)$, using tensiometers (ceramic: P-80, CeramTec Ag, Marktredwitz, Germany) equipped with pressure transducers (PCFA6D, Honeywell; Morristown, NJ, USA). Pressure heads at 100$\mathrm{cm}$ depth were recorded in hourly intervals from December 2009 using dataloggers (DL2 and DL2e, Delta-T Devices, Cambridge, UK). Monitoring of shallower soil depths began in May 2010. The tensiometers at 100-cm depth were placed in two parallel transects with a distance of $1 \mathrm{~m}$ between and within transects, crossing plant rows with an angle of $45^{\circ}$.
The probes were installed at an angle of $30^{\circ}$ to the soil surface in order to prevent preferential water flowing down the shaft of the instrument. Data quality assessment of water tension time series was done following the protocol described in Wegehenkel (2005) [33]. Average soil water tensions were excluded from the model performance evaluation for periods where the values of one or more tensiometers had to be rejected, i.e., because dry soil conditions beneath the measuring limit $(-850 \mathrm{hPa})$.

Stand precipitation measurements were conducted on W05/90 during the vegetation period 2010 using two $4 \mathrm{~m}$ long gutters with a width of $0.16 \mathrm{~m}\left(0.65 \mathrm{~m}^{2}\right)$ made from stainless steel. The gutters were mounted on an $80 \mathrm{~cm}$ high wooden rack, water was collected in barrels $(30 \mathrm{~L})$ that were emptied when necessary, though at minimum every second week.

\section{Vegetation Characteristics}

On the plots chosen for water balance simulations (Ref, W05/90), important vegetation characteristics like leaf area per unit ground area (leaf area index, LAI), canopy height and vertical root distributions were surveyed for the use as model input. Information on vertical root distributions came from Punzet (2011, unpublished). Canopy height was measured after the growing seasons using a measuring rod. LAI was measured with a Sunscan light interception probe (SS1, Delta-T Devices, Cambridge, UK) at three dates per growing season. As recommended by the manual of the probe, the measurements were conducted on days with stable light conditions, either on bright and sunny days or on days with a uniform overcast sky. On each measuring campaign, 50 readings were taken on fixed transect points inside the canopy. In order to avoid boundary effects, all measuring points were more than three tree lengths away from the stand edges. Before each 10 readings, the probe was referenced by measuring incident radiation outside the canopy on an open field, as well three tree lengths away from the stand edges.

\section{Statistical Analysis}

All soil properties and nitrate concentration data were checked to satisfy the conditions of normal distribution (Chi Quadrat test) homoscedasticity of residuals (Levene's test) prior parametric testing. However, critical values $(p \leq 0.05)$ indicated a non-normal distribution and unequal variances of the soil properties data set. Thus, the non-parametric Kruskal-Wallis analysis of variance approach was used to find significant $(p \leq 0.05)$ differences between chemical parameters of plots for identical soil horizons (Table 4). Statistics on soil properties were applied using the software package STATISTICA, Version 9 (StatSoftGmbH, Hamburg, Germany). 
Nitrate concentrations of the soil solution were analyzed using a linear mixed effects model [34], to account for the sample-point identity of measurements. The full model included the effect of the research plot, the drainage period (level "A": spring 2010 and level "B": winter/spring 2010/ $11)$ and their interaction effect. Sample point and sampling date were treated as random effects. Model comparisons were done using Akaike's information criterion [35] and likelihood ratio tests [34], with the conclusion that the sampling date could be excluded from random effects. Diagnostic plots were used to check normality and homoscedasticity of residuals and proved no severe violation of assumptions. For identifying differences between nitrate concentration means on the plot and drainage period level, all orthogonal contrasts were specified. The original level of significance $(\alpha=0.05)$ was adjusted to account for multiple comparisons of plots and periods. The analysis was conducted using the NLME package [36] provided by the statistical software R [37].

For evaluating the performance of the water balance simulation model, the coefficient of determination $\left(R^{2}\right)$ of a linear regression between simulated and observed values, the root mean square error (RMSE) and mean error (ME) were used as objective measures. The ME quantifies the mean absolute difference between simulated and observed values, RMSE is calculated as the square root of the mean squared difference between simulated and observed values.

\section{Simulation Model}

\section{Model Description}

The CoupModel (Version 3.0 [26]), formerly known as SOIL model, was used to estimate the components of the water balance of the Ref (grass cover) and W05/90 (willow canopy) plots. The CoupModel is a physical process model that simulates one-dimensional heat and water flows through a layered soil profile, which is covered with vegetation. It produces - after adjustment of soil and vegetation properties to site conditions - reliable estimates of evapotranspiration, groundwater recharge and other variables that are difficult to monitor in the field. In the past, it was successfully applied and verified on willow SRC stands [24, 38], crop production systems [39], forests [40, 41] and grass land sites [42]. Soil water flows are calculated by solving Richard's equation for saturated and unsaturated flow. This approach requires the hydraulic properties of the soil layers, that are described by the formulations of Brooks and Corey [43] (retention characteristics) and Mualem [44] (hydraulic conductivity). Richard's equation allows for soil water sources and sinks, i.e., root water uptake driven by transpiration. Potential transpiration $\left(T_{p}\right)$, interception evaporation $\left(E_{i}\right)$ from wet plant surfaces and soil evaporation $\left(E_{s}\right)$ are calculated separately for one or more canopy layers and the soil surface using the Penman-Monteith combination equation [45]. Actual transpiration as the sum of root water uptake from soil layers is calculated on the basis of potential transpiration, which is reduced by taking actual soil water availabilities, soil temperatures and root densities of the soil layers into account.

\section{Simulation Setup and Parameterization}

The simulations of the Ref and W05/90 plots were run with hourly resolution from January 2009 (initial soil water tension of all layers, $-60 \mathrm{hPa}$ ) until the end of December 2011, driven by the meteorological input data set. The period of interest includes the years 2010 and 2011, for which daily output of water balance components and state variables were produced. For both simulations, soil profiles with 20 layers and a total depth of $2.55 \mathrm{~m}$ were defined. The thickness of the soil layers gradually increased from $5 \mathrm{~cm}$ in the uppermost $35 \mathrm{~cm}$ to $30 \mathrm{~cm}$ in the two deepest layers. Upper and lower boundary conditions were defined as flux boundaries with the upper boundary taking the stand precipitation into account. As lower boundary condition, a unit gradient gravitational water flow was setup, which in this study represents groundwater recharge. Capillary rise was not considered.

For the description of the physical and physiological properties of the willow canopy (i.e., stomata and aerodynamic resistance functions according to $[46,47])$, we used the parameterisation of Persson and Lindroth [38] (Table 3). They simulated evapotranspiration rates of a willow stand on clay soil using the older version (SOIL) of the CoupModel and verified the model with measured stand evapotranspiration. $R^{2}$ ranged from 0.73 to 0.79 , the model only slightly overestimated evapotranspiration during two growing seasons by 2 and $10 \mathrm{~mm}$ [38].

Vegetation (Table 3) and soil characteristics (Table 2) were chosen to represent our site conditions with respect to measured LAI, canopy height, root distribution and soil hydraulic properties. Model LAI development during the growing seasons was defined to match the measured values on W05/90. For estimating the actual dates of budburst and leaf fall, we applied a critical day length and temperature sum model [26]. A maximum stand average LAI of $4.2 \mathrm{~m}^{2} \mathrm{~m}^{-2}$ was reached in June 2010 . In the following month, LAI dropped to about $2 \mathrm{~m}^{2} \mathrm{~m}^{-2}$, likely due to enduring water scarcity. In 2010, average canopy height of the willow stand was $7.5 \mathrm{~m}$. After harvest in early 2011, the stand re-sprouted to about $3 \mathrm{~m}$ during the growing season. The maximum LAI $\left(3.8 \mathrm{~m}^{2} \mathrm{~m}^{-2}\right)$ of the growing season 2011 was reached at the end of August.

The observed root distribution was in good accordance to other reported observations [48] in SRC stands. Most fine roots $(80 \%)$ were found in the upper $60 \mathrm{~cm}$ of the soil 
Bioenerg. Res.

Table 2 Soil hydraulic properties used in the water balance simulation for the plots Ref and W05/90

\begin{tabular}{|c|c|c|c|c|c|c|c|c|c|}
\hline Plot & Depth $(\mathrm{cm})$ & $\begin{array}{l}\text { Lambda } \\
(-)\end{array}$ & $\begin{array}{l}\text { Air entry } \\
(\mathrm{hPa})\end{array}$ & $\begin{array}{l}\text { Saturation } \\
(\mathrm{vol} \%)\end{array}$ & $\begin{array}{l}\text { Wilting point } \\
\text { (vol. \%) }\end{array}$ & $\begin{array}{l}\text { Residual water } \\
\text { (vol\%) }\end{array}$ & $\begin{array}{l}\text { Matrix cond. } \\
\left(\mathrm{mm} \mathrm{day}^{-1}\right)\end{array}$ & $\begin{array}{l}\text { Total cond. } \\
\left(\mathrm{mm} \mathrm{day}^{-1}\right)\end{array}$ & Tortuosity (-) \\
\hline \multirow[t]{3}{*}{ Ref } & $0-35$ & 0.196 & 5.02 & 52.0 & 10.3 & 4.2 & 2,000 & 2,000 & 1 \\
\hline & $35-55$ & 0.478 & 1.84 & 44.1 & 6.3 & 2.0 & 5,000 & 5,000 & 1 \\
\hline & $55-255$ & 0.816 & 0.82 & 38.8 & 3.8 & 6.7 & 10,000 & 10,000 & 1 \\
\hline \multirow[t]{6}{*}{ W05/90 } & $0-10$ & 0.464 & 1.98 & 46.4 & 3.6 & 6.9 & 1,070 & 1,070 & 1 \\
\hline & $10-20$ & 0.204 & 7.75 & 55.6 & 9.5 & 6.6 & 8,100 & 8,100 & 1 \\
\hline & $20-35$ & 0.246 & 8.36 & 55.4 & 10.9 & 17.2 & 5,400 & 5,400 & 1 \\
\hline & $35-55$ & 0.118 & 1.71 & 51.0 & 9.9 & 3.9 & 740 & 740 & 1 \\
\hline & $55-70$ & 0.518 & 1.91 & 48.9 & 6.3 & 13.3 & 2,350 & 2,350 & 1 \\
\hline & $70-255$ & 0.816 & 5.62 & 38.8 & 3.8 & 6.7 & 10,800 & 10,800 & 1 \\
\hline
\end{tabular}

profile. Below the R2+E horizon, roots sporadically occurred down to a depth of $180 \mathrm{~cm}$.

The parameters of the retention function (Table 2) were obtained by least squares fitting of observed water content/ pressure head points of the horizons. Hydraulic conductivity functions were derived from the grain size distributions using built-in CoupModel routines. In spring 2011, soil water tensions in $30 \mathrm{~cm}$ indicated root water uptake, before the recently harvested willow stand had developed new shoots. To account for this water uptake, a grass layer was defined underneath the willow canopy. This grass layer was assumed to have the same properties as the grass layer defined in the simulation of the Ref plot (Table 3), except for the maximum LAI, which we assigned a lower value $\left(3 \mathrm{~m}^{2} \mathrm{~m}^{-2}\right)$. Vegetation properties to simulate the Ref plot were taken from Lundmark [42], hydraulic properties of the soil horizons and the vertical root distribution were derived from field measurements. On the Ref plot, most fine roots $(95 \%)$ were located in the former Ap horizon, only few roots of dicot plants reached down to $90 \mathrm{~cm}$.

With respect to our measured stand precipitation and soil water tension data, adjustments of the original parameter sets $[38,42]$ had to be carried out, to obtain a better agreement between simulated and measured variables and thus a better estimation of the water balance components. Stand precipitation measurements on the willow plot indicated underestimated interception evaporation when using the canopy storage capacity parameters $\left(I_{\mathrm{c}}, I_{\mathrm{LAI}}\right)$ of a previous study [38], likely due to the higher temporal resolution $(1 \mathrm{~h})$ of our simulation. Adjustments of these parameters and the interception surface resistance $\left(r_{\mathrm{ci}}\right.$, Table 3$)$ led to a better agreement between simulated and observed stand precipitation. Hydraulic conductivities derived from grain size distributions were adjusted considering the observed soil water tensions at field capacity during winter time. The $\mathrm{RWU}_{\text {comp }}$ parameter for water uptake compensation was used to improve the agreement between observed and simulated soil water tensions during the growing season.

Table 3 Adjusted CoupModel parameter values for the simulations of the W05/90 and Ref plots

\begin{tabular}{|c|c|c|c|}
\hline CoupModel parameter & Unit & $\begin{array}{l}\text { Willow canopy } \\
\text { W05/90 }\end{array}$ & $\begin{array}{l}\text { Grass layer } \\
\text { Ref }\end{array}$ \\
\hline $\begin{array}{l}\text { Interception constant } \\
\text { capacity }\left(I_{c}\right)\end{array}$ & $\mathrm{mm}$ & 0.2 & 0 \\
\hline $\begin{array}{l}\text { Interception capacity } \\
\text { per LAI }\left(I_{L A I}\right)\end{array}$ & $\mathrm{mm}$ & 0.25 & 0.25 \\
\hline $\begin{array}{l}\text { Interception surface } \\
\text { resistance }\left(r_{c i}\right)\end{array}$ & $\mathrm{s} \mathrm{m}^{-1}$ & 0.5 & 5 \\
\hline Reference height & $\mathrm{m}$ & 10 & 2 \\
\hline $\begin{array}{l}\text { Parameter in soil } \\
\text { surface resistance } \\
\text { function }\end{array}$ & $\mathrm{hPa}$ & 1,000 & 1,000 \\
\hline $\begin{array}{l}\text { Crit. threshold for } \\
\text { water uptake } \\
\text { reduction }\left(\Psi_{\text {crit }}\right)\end{array}$ & $\mathrm{hPa}$ & 400 & 400 \\
\hline $\begin{array}{l}\text { Degree of root water } \\
\text { uptake compensation } \\
\text { from moist soil } \\
\left.\text { layers ( } \mathrm{RWU}_{\text {comp }}\right)\end{array}$ & - & 0.45 & 0.25 \\
\hline $\begin{array}{l}\text { Maximum stomata } \\
\text { conductance }\left(g_{\max }\right)\end{array}$ & $\mathrm{m} \mathrm{s}^{-1}$ & 0.015 & 0.02 \\
\hline $\begin{array}{l}\text { Sensitivity of stomata } \\
\text { conductance to } \\
\text { VPD }(b)\end{array}$ & $\mathrm{Pa}$ & 1,318 & 100 \\
\hline $\begin{array}{l}\text { Sensitivity of stomata } \\
\text { conductance to } \\
\text { global short wave } \\
\text { radiation }\left(R_{0}\right)\end{array}$ & $\mathrm{MJ} \mathrm{m}^{-2}$ day $^{-1}$ & 11.8 & 5 \\
\hline $\begin{array}{l}\text { Aerodynamic } \\
\text { resistance }\left(r_{a}\right)\end{array}$ & $\mathrm{s} \mathrm{m}^{-1}$ & $3-676$ & $30-708$ \\
\hline Root depth & $\mathrm{m}$ & 1.8 & $0.7-1.0$ \\
\hline Canopy height & $\mathrm{m}$ & $0.1-7.5$ & $0.05-0.35$ \\
\hline Leaf area index (LAI) & $\mathrm{m}^{2} \mathrm{~m}^{-2}$ & $0-4.2$ & $1.5-3.5$ \\
\hline $\begin{array}{l}\text { Critical air temperature } \\
\text { for temperature sum } \\
\text { calculation }\end{array}$ & ${ }^{\circ} \mathrm{C}$ & 9 & 8.5 \\
\hline $\begin{array}{l}\text { Temperature sum to } \\
\text { start leaf } \\
\text { development }\end{array}$ & ${ }^{\circ} \mathrm{C}$ & 50 & 50 \\
\hline
\end{tabular}


As in the simulation of W05/90 plot, adjustments of the Ref parameter set included soil hydraulic conductivities and root water uptake compensation $\left(\mathrm{RWU}_{\mathrm{comp}}\right)$. Additionally, the shape of the seasonal LAI development was adjusted.

\section{Results}

\section{Basic Soil Parameters}

The $C_{\mathrm{org}}$ and the $N_{t}$ of the soil profiles clearly mirror the deep-plowing effect on the plots P09/90 and W05/90 (Table 4). $C_{\text {org }}$ and $N_{t}$ values are enhanced in the mid soil layers of $30-50 \mathrm{~cm}$ soil depth, whereas highest $C_{\text {org }}$ and $N_{t}$ values of the reference plot (Ref) and the two conventionally plowed (30 cm soil depth) poplar and willow plots (P94/30, W $94 / 30$ ) were found in the upper $0-30 \mathrm{~cm}$ soil depth. With more than $7 \%, C_{\text {org }}$ content was highest in the upper $10 \mathrm{~cm}$ of the reference plot and lowest in the top layer of the deeply plowed P09/90 plot $\left(0.2 \% C_{\text {org }}\right)$. Due to the soil mixture after the plowing on the SRC plots, measured soil values generally indicate a high spatial variability and thus could only be proved to be statistically different in some cases (e.g., for $C_{\text {org }}$ and $N_{t}, \mathrm{P} 09 / 90$ versus Ref., $0-10 \mathrm{~cm}$ soil depth). Because of relatively low $C_{\text {org }}$ values in the top and lowest layer of the $\mathrm{P} 09 / 90$ plot, $\mathrm{C} / \mathrm{N}$ ratios are relatively low as well (9.9-10.9).
On the other plots, $\mathrm{C} / \mathrm{N}$ ratios ranged from about 11 in the lower soil horizons (Ref, $30-50 \mathrm{~cm}$ soil depth) to more than 26 in the upper soil horizons (P94/30). Even if not statistically provable, there is a tendency towards relatively low $\mathrm{C} / \mathrm{N}$ ratios for all soil layers on the deeply plowed P09/90 and W05/90 plots, which might already indicate the potential of nitrate leaching on these two plots. Results of the mineral $\mathrm{N}$ analysis $\left(\mathrm{N}_{\text {min }}\right)$ indicate a shift towards higher values only in the 10$30 \mathrm{~cm}$ soil layer in the $\mathrm{P} 09 / 90$ and $\mathrm{W} 05 / 90$ plots, while horizons below and above showed reduced values. Conventional plowing of the topsoil $(30 \mathrm{~cm})$ alone, as applied at the $\mathrm{P} 94 / 30$ and $\mathrm{W} 94 / 30$ plots did not change the vertical gradient of the $\mathrm{N}_{\min }$ values, compared to the reference plot.

Compared to conventional cropland sites of the region $\mathrm{N}_{\min }$ values are low. Higher $\mathrm{N}_{\min }$ values of the top soilrespectively the former top soil in $10-30 \mathrm{~cm}$ soil depth on the plowed $\mathrm{P} 09 /{ }_{90}$ and $\mathrm{W} 05 / 90$ plots - are correlating with higher values of $N_{\text {org }}$. Furthermore, mean percentage of nitrate in total $\mathrm{N}_{\min }\left(\mathrm{NO}_{3}+\mathrm{NH}_{4}\right)$ was not detectable in the $30-50 \mathrm{~cm}$ soil layer at the reference plot but also not in the most upper layer of the $\mathrm{P} 09 / 90$ plot-which in fact here is also the former deep layer, transferred by deep plowing to the top of the profile. As far as $\mathrm{N}_{\min }$ was detectable in deeper horizons at all SRC plots, nitrate was the dominant constituent. The $\mathrm{pH}(1 \mathrm{M} \mathrm{KCl})$ values of all plots and soil layers range between 4.1 and 5.7, with a tendency towards higher

Table 4 Mean $( \pm \mathrm{SD})$ soil chemical background conditions of the SRC plots in the Fuhrberger Feld

\begin{tabular}{|c|c|c|c|c|c|c|c|c|}
\hline Plot & Soil depth $(\mathrm{cm})$ & $\mathrm{pH}(1 \mathrm{M} \mathrm{KCl})$ & $C_{\text {org }}(\mathrm{mg} / \mathrm{g})$ & $N_{t}(\mathrm{mg} / \mathrm{g})$ & $\mathrm{C} / \mathrm{N}(\mathrm{mg} / \mathrm{mg})$ & $\mathrm{N}_{\min }\left(\mathrm{NO}_{3}+\mathrm{NH}_{4}\right)(\mathrm{mg} / \mathrm{kg})$ & $\mathrm{NO}_{3} / \mathrm{N}_{\min }(\%)$ & $N_{\text {org }}(\mathrm{mg} / \mathrm{kg})$ \\
\hline \multirow[t]{4}{*}{$\mathrm{P} 09 / 90$} & $0-10$ & $4.4(0.2)$ & $2.0(0.2) a$ & $0.2(0.0) a$ & $9.9 a$ & $\leq$ d.l. & 0 & $2.57(0.81) a$ \\
\hline & $10-30$ & $5.0(0.4)$ & $13.0(10.4)$ & $0.8(0.6)$ & $14.3 a$ & $7.29(1.09)$ & 79 & $6.98(0.87)$ \\
\hline & $30-50$ & $5.1(0.2)$ & $40.7(3.2)$ & $2.4(0.1)$ & 16.8 & $1.62(0.00)$ & 100 & $2.33(1.08)$ \\
\hline & $50-70$ & $4.1(0.2)$ & $2.3(1.5)$ & $\leq$ d.l. & - & n.t. & - & n.t. \\
\hline \multirow[t]{4}{*}{$\mathrm{P} 94 / 30$} & $0-10$ & $4.6(0.1)$ & $52.8(1.9)$ & $2.0(0.1)$ & $26.4 b$ & $2.86(0.86)$ & 74 & $5.56(0.48)$ \\
\hline & $10-30$ & $4.6(0.1)$ & $50.5(3.0)$ & $1.8(0.1)$ & $27.6 b$ & $1.62(0.00)$ & 100 & $6.78(0.68)$ \\
\hline & $30-50$ & $4.4(0.1)$ & $10.9(4.1)$ & $0.5(0.2)$ & $22.0 a$ & $\leq$ d.l. & 0 & $2.69(0.23)$ \\
\hline & $50-70$ & $4.3(0.1)$ & $4.8(2.2)$ & $0.3(0.1)$ & 18.6 & n.t. & - & n.t. \\
\hline \multirow[t]{4}{*}{ W05/90 } & $0-10$ & $5.2(0.2)$ & $19.1(8.4)$ & $1.1(0.5)$ & 17.2 & $1.17(0.00)$ & 100 & $3.73(1.14)$ \\
\hline & $10-30$ & $5.7(0.3)$ & $44.7(2.3)$ & $2.6(0.1)$ & 17.5 & $3.67(0.69)$ & 84 & $7.21(1.19)$ \\
\hline & $30-50$ & $5.7(0.2) a$ & $42.8(8.2) a$ & $2.5(0.5) a$ & 17.3 & $0.66(0.00)$ & 100 & $2.78(0.66)$ \\
\hline & $50-70$ & $4.1(0.2)$ & $2.4(0.4)$ & $\leq$ d.l. & - & n.t. & - & n.t. \\
\hline \multirow[t]{4}{*}{$\mathrm{W} 94 / 30$} & $0-10$ & $5.2(0.2)$ & $53.2(3.2)$ & $2.2(0.1)$ & 24.0 & $2.83(0.86) b$ & 74 & $5.56(1.00)$ \\
\hline & $10-30$ & $4.9(0.1)$ & 47.7 (4.9) & $1.9(0.1)$ & 25.1 & $1.52(0.00)$ & 100 & $6.78(0.58)$ \\
\hline & $30-50$ & $4.6(0.3)$ & $30.6(12.9)$ & $1.3(0.2)$ & 24.3 & $0.29(0.00)$ & 100 & $2.69(0.70)$ \\
\hline & $50-70$ & $4.2(0.2)$ & $5.6(1.9)$ & $0.3(0.1)$ & 19.4 & n.t. & - & n.t. \\
\hline \multirow[t]{4}{*}{ Ref } & $0-10$ & $4.4(0.1)$ & 71.7 (12.6) $b$ & $3.2(0.6) b$ & 22.6 & $2.40(0.70)$ & 75 & $6.72(0.91) b$ \\
\hline & $10-30$ & $4.5(0.5)$ & $59.3(31.3)$ & $2.4(1.1)$ & 24.3 & $1.76(0.67)$ & 67 & $5.47(1.14)$ \\
\hline & $30-50$ & $4.3(0.1) b$ & $1.9(0.3) b$ & $0.2(0.0) b$ & $11.4 b$ & $\leq$ d.l. & 0 & $2.24(2.12)$ \\
\hline & $50-70$ & $4.2(0.1)$ & $2.1(1.1)$ & $\leq$ d.l. & - & n.t. & - & n.t. \\
\hline
\end{tabular}

Samples were taken in June 2010 with $n=3$ per layer and plot (d.l. detection limit, n.t. not detected). Different letters indicate significant ( $p \leq 0.05$ ) differences between the same soil layer of different plots 
values on the W05/90 plot. However, differences proved to be statistically significant in only one case $(30-50 \mathrm{~cm}$ soil depth, W05/90 versus Ref).

\section{Nitrate Soil Solution Concentrations}

Figure 1 shows the time series of monthly mean nitrate concentrations in the soil solution at $100 \mathrm{~cm}$ soil depth, measured from February to May 2010 (period A) and from December 2010 to June 2011 (period B). Estimated nitrate concentration means including standard errors as well as statistical differences between means of the plots and between periods are given in Table 5. Statistical tests show that plot and period both have a significant influence $(p<0.0001)$ on nitrate concentrations. The significant $(p<0.0001)$ interaction between both factors suggests different plot behavior for the sampling periods.

In period A (spring 2010), there is a relatively clear sequence of the nitrate concentration levels between a mean of above 16 to below $1 \mathrm{mg} \mathrm{NO}_{3}-\mathrm{N} \mathrm{L}^{-1}(\mathrm{P} 09 / 90>\mathrm{W} 94 / 30>\mathrm{W} 05 / 90>\mathrm{P} 94 / 30>$ Ref, Fig. 1). Concentrations of Ref and P94/30 thereby do not differ significantly from zero (Table $5 \mathrm{a}$ ). In period B (winter/ spring 2010/11; Table 5b), only the concentrations of W94/30 remain on the same high level of period A (no significant differences between periods). Nitrate concentrations of $\mathrm{P} 94 / 30$ in period B are as well at the very low concentration level of the reference plot, concentrations of $\mathrm{P} 09 / 90$ and W94/30 remain significantly higher than concentrations of Ref (Table 5). At the beginning of period $\mathrm{B}$, nitrate concentrations of $\mathrm{P} 09 / 90$ started again at an elevated level but then strongly decreased to the level of the W05/90 plot. Finally, the estimated mean nitrate concentration of $\mathrm{W} 05 / 90$ in period B turned out to be significantly reduced compared to period A (Table $5 \mathrm{a}, \mathrm{b}$ ).

Significant differences of the estimated mean nitrate concentrations in period A were found for the comparisons
Ref-P09/90, Ref-W94/30, P09/90-P94/30, and P09/90-W05/90 (Table 5a). In period B (Table 5b), the differences between W05/90 and P09/90 were not significant anymore, but the differences between W94/30 and P94/30 became significant.

However, as already described for the soil matrix, the spatial variability of the solute nitrate concentrations is high, especially when the concentration is low. In both sampling periods, the variation coefficient is between 100 and $200 \%$ on the $\mathrm{P} 94 / 30$ plot, but is lower (around 14-65\%) when nitrate concentrations are enhanced ( $\mathrm{P} 09 / 90$ and $\mathrm{W} 94 / 30$, both periods).

\section{Simulated and Observed Pressure Heads}

Figure $2 \mathrm{a}$ and $\mathrm{b}$ show the time series of the mean, minimum and maximum observed soil water tensions in $100 \mathrm{~cm}$ depth on the Ref and W05/90 plots, in combination with the corresponding simulated values of the soil layer in $95-105 \mathrm{~cm}$ depth. The seasonal pattern is similar on both plots. During winter, all tensiometers show values around field capacity. With budburst in spring and beginning root water uptake, soil water potentials start to decrease and the spatial variability increases. Pressure heads on Ref start to decrease later, less strong and in fewer locations compared to the pressure heads of the willow plot. As a consequence, thorough rewetting of the soil on Ref is attained earlier in autumn when root water uptake ceases. In 2010, drainage formation on Ref can be expected to start already after a heavy rain storm at the end of August after which soil water potentials in $100 \mathrm{~cm}$ indicate field capacity. At the same time, many tensiometers on the W05/90 plot did not work properly, indicating soil water tensions near or beyond the measuring limit $(-850 \mathrm{hPa})$ since July 2010.

A similar seasonal pattern is revealed by tensiometry in summer 2011. After a series of heavy rain storms at the end of June, the soil in $100 \mathrm{~cm}$ depth on Ref is completely
Fig. 1 Monthly mean nitrate concentrations of SRC plots in the Fuhrberger Feld at $100 \mathrm{~cm}$ soil depth from Feb 2010 to Jun 2011 (due to dry conditions, no samples could be obtained between June and Nov 2011)

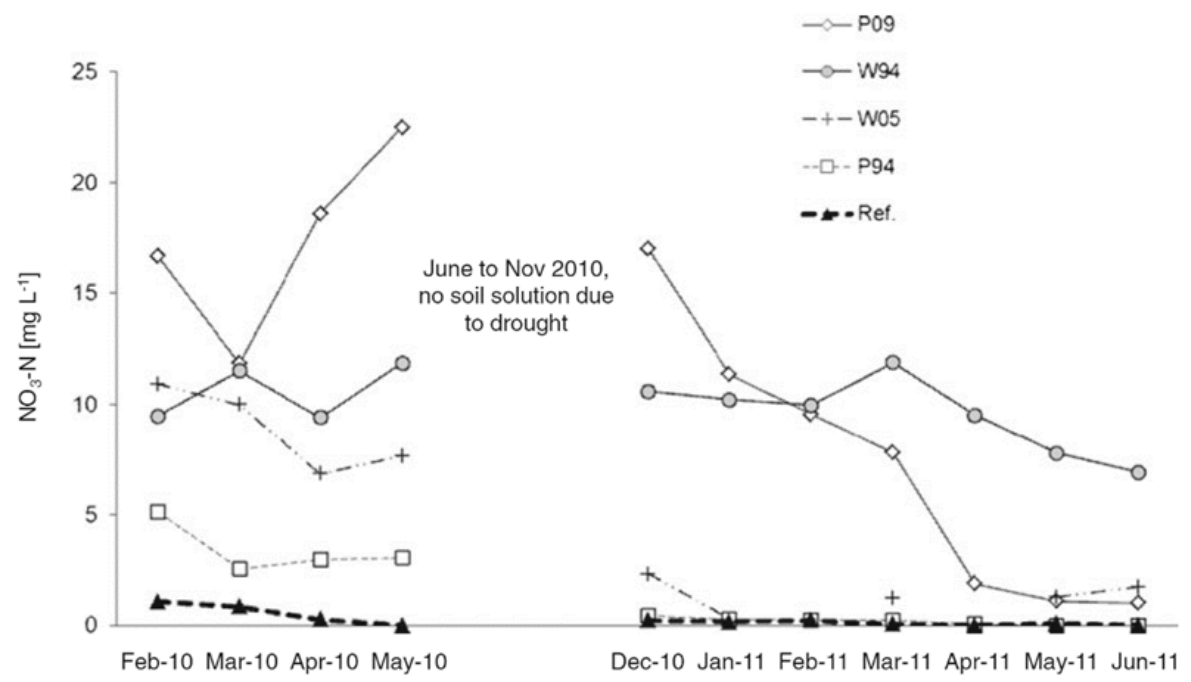

Q Springer 
Bioenerg. Res.

Table 5 Estimated mean nitrate concentrations $\left(\mathrm{NO}_{3}-\mathrm{N} \mathrm{L}^{-1}\right)$ of the study plots, separated for period A (Feb 2010-May 2010; Table $5 \mathrm{a}$ ) and period $\mathrm{B}(\mathrm{Dec}$ 2010-June 2011; Table 5b)
On the diagonal: estimates, intercept significance levels (n. sign. not significant) and standard errors (SE) of estimates. Letters denote significant membership to the periods $\mathrm{A}$ and B. Significances for plot comparisons are specified below the diagonal. The original signifito account for multiple comparisons cance level $\alpha=0.05$ was adjusted

\begin{tabular}{|c|c|c|c|c|c|}
\hline $\begin{array}{l}\text { Estimate } \\
p \text { value } \\
\mathrm{SE}\end{array}$ & Ref & $\mathrm{P} 09 / 90$ & $\mathrm{P} 94 / 30$ & W05/90 & W94/30 \\
\hline \multicolumn{6}{|l|}{ a) } \\
\hline Ref & $\begin{array}{l}0.62 \mathrm{~A}, \mathrm{~B} \\
\mathrm{n} . \text { sign. } \\
1.77\end{array}$ & & & & \\
\hline $\mathrm{P} 09 / 90$ & $<0.0001$ & $\begin{array}{l}16.64 \mathrm{~A} \\
<0.0001 \\
1.61\end{array}$ & & & \\
\hline $\mathrm{P} 94 / 30$ & n. sign. & $<0.0001$ & $\begin{array}{l}3.33 \mathrm{~A}, \mathrm{~B} \\
\text { n.sign. } \\
1.63\end{array}$ & & \\
\hline W05/90 & n.sign. & $<0.0001$ & n. sign. & $\begin{array}{l}7.81 \mathrm{~A} \\
<0.0001 \\
1.64\end{array}$ & \\
\hline W94/30 & 0.0007 & n.sign. & n.sign, & n. sign. & $\begin{array}{l}10.38 \text { A,B } \\
<0.0001 \\
1.76\end{array}$ \\
\hline \multicolumn{6}{|l|}{ b) } \\
\hline Ref & $\begin{array}{l}0.11 \mathrm{~A}, \mathrm{~B} \\
\mathrm{n} . \text { sign. } \\
1.59\end{array}$ & & & & \\
\hline P09/90 & 0.0005 & $\begin{array}{l}9.1 \mathrm{~B} \\
<0.0001 \\
1.57\end{array}$ & & & \\
\hline $\mathrm{P} 94 / 30$ & n.sign. & 0.0005 & $\begin{array}{l}0.27 \mathrm{~A}, \mathrm{~B} \\
\text { n. sign. } \\
1.53\end{array}$ & & \\
\hline W05/90 & n. sign. & n. sign. & n. sign. & $\begin{array}{l}2.23 \mathrm{~B} \\
\text { n. sign. } \\
1.75\end{array}$ & \\
\hline W94/30 & 0.0002 & n. sign. & 0.0002 & n.sign. & $\begin{array}{l}10.09 \text { A,B } \\
<0.0001 \\
1.65\end{array}$ \\
\hline
\end{tabular}

rewetted and remains relatively moist throughout the rest of the growing season. Potentials on W05/90 show only slight increases during that period. The soil stays relatively dry, though inside the measuring range until beginning of December 2011. Thus, considerable groundwater recharge cannot be expected before the end of the year.

The visible agreement between observed and simulated soil water tensions, in combination with performance indicators (Table 6) suggests an acceptable performance of the CoupModel. The important points in time like the beginning of root water uptake in spring and the rewetting in autumn meet well with observations, except for the rewetting in autumn 2010 on W05/90. Here, the point in time of water flow breakthrough in $100 \mathrm{~cm}$ could not be monitored, due to measuring errors caused by the dry subsoil. However, coefficients of determination (Table 6) are relatively good for pressure head data [33] and the absolute deviation from measurements is low. The fact that measured values of soil water storage capacities (retention curves) were used in the simulations and throughfall was only slightly overestimated (ME; $1.4 \mathrm{~mm}$, Table 6 , possibly due to wetting and evaporation losses during measurements), strengthens our belief that the estimations of the water balance components are reliable.

\section{Simulated Water Budgets}

The monthly and annual sums of the simulated water balance components for the study plots are illustrated in Fig. 3a 

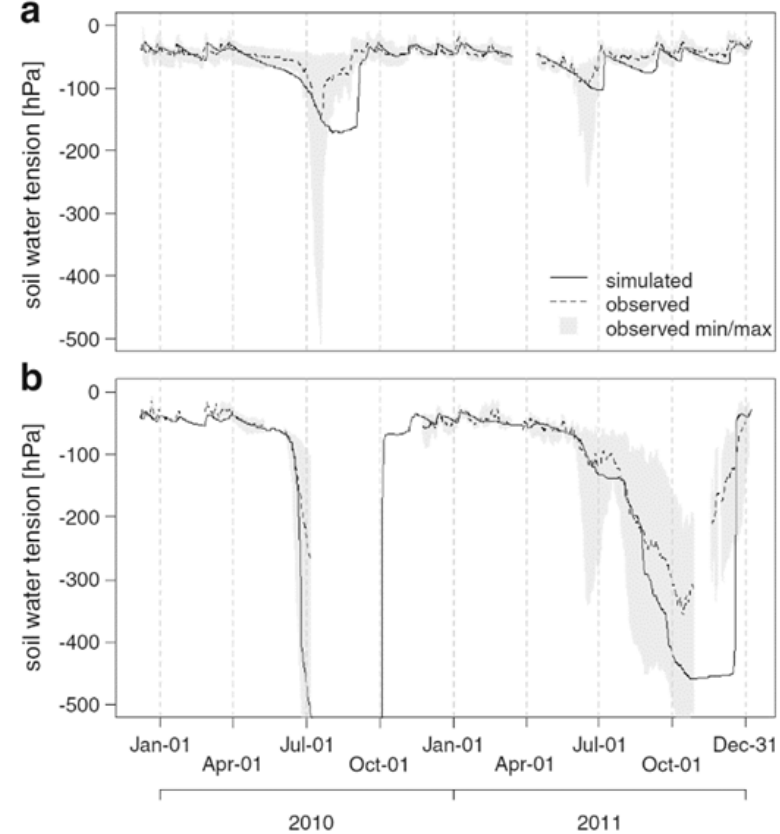

Fig. 2 a, b Mean observed $(n=10)$ and simulated soil water tensions of Ref (a) and W05/90 (b) study plots at $100 \mathrm{~cm}$ soil depths. Shaded area $\operatorname{minimum} /$ maximum of observations

and $b$ and Table 7. Interception and transpiration of the willow plot include the evaporation rates of the grass layer beneath the willow canopy.

Similar to the seasonal variation in the soil water tensions, a clear pattern can be seen in the monthly sums of the water balance components of the study plots. Actual evapotranspiration $\left(\mathrm{ET}_{\mathrm{a}}\right)$ as the sum of transpiration $\left(T_{a}\right), E_{i}$ and $E_{s}$ has the highest values during the growing season, whereas drainage from the soil profiles takes place mainly in winter. The transitions between these hydrological seasons are smooth, with a gradual shift towards $\mathrm{ET}_{\mathrm{a}}$ in spring and a more abrupt beginning of the drainage period in autumn or winter. Simulated monthly $E_{i}$ and $T_{a}$ from W05/90 are higher than from Ref (Fig. 3a); in summer, $\mathrm{ET}_{\mathrm{a}}$ generally is equal or even higher than precipitation. In July $2010, T_{a}$ is extraordinary low in both simulations, due to low amounts of precipitation in June and July and pronounced soil water deficits in the root zone.

The simulated groundwater recharge from $\mathrm{W} 05 / 90$ ceases during summer almost completely, while small amounts of drainage are formed on Ref throughout the whole observation period. On Ref, considerable monthly groundwater recharge rates are attained already in October 2010, while groundwater recharge from W05/90 does not start before December. In 2011, the winter drainage period did not start until the end of the simulation period, whereas seepage from Ref started to increase already in October.

The differences in seasonal water partitioning patterns between the simulated land use types are reflected in the annual sums of the water balance components. Especially annual $E_{i}$ and $T_{a}$ are higher from the willow stand (Table 7). During the simulation period, average $E_{i}$ losses from W05/90 account for $25 \%$ of precipitation, contrasted by $12 \%$ on Ref. Simulated root water uptake on W05/90 is in both years about $60 \mathrm{~mm}$ higher.

The differences in annual evapotranspiration rates between the land use types result in large differences in the amount of water leaving the soil profiles and serving as groundwater recharge. On Ref, $345 \mathrm{~mm}$ drainage formed in the year 2010 (Table 7), which is more than half of the annual precipitation. In contrast to that, $189 \mathrm{~mm} \mathrm{(29 \%} \mathrm{of}$ precipitation) groundwater recharge is formed on W05/90. In 2011, these differences are not as expressed, although the soil profile of W05/90 was not rewetted completely (Table 7) by the end of the simulation period. For the whole simulation period, average annual groundwater recharge from W05/90 $\left(180 \mathrm{~mm} \mathrm{a}^{-1}\right)$ is approximately $40 \%$ lower than groundwater recharge from Ref $\left(300 \mathrm{~mm} \mathrm{a}^{-1}\right)$.

\section{Discussion}

The German Biomass Research Center [49] has calculated that by 2020 , there will be a net lack of about 270 PJ per year in the German energy and material related wood market. If this "wood gap" would be filled by the establishment of SRC plantations, it would result in an extra need of about 1.2 million ha [49]. The current (2011) total cropland area in
Table 6 Performance statistics for simulated soil water tensions and throughfall. Indicators for soil water tension performance are means for three $(30-35 \mathrm{~cm}$; $55-65 \mathrm{~cm}$ ) respectively ten $(95-105 \mathrm{~cm})$ tensiometers

\begin{tabular}{llllllr}
\hline Variable & Plot & Horizon $(\mathrm{cm})$ & $R^{2}$ & RMSE & ME & $n$ Obs. \\
\hline Soil water tension & \multirow{2}{*}{ Ref } & $30-35$ & 0.67 & $148 \mathrm{hpa}$ & $-81 \mathrm{hpa}$ & 512 \\
& & $55-65$ & 0.52 & $177 \mathrm{hpa}$ & $-71 \mathrm{hpa}$ & 606 \\
& & $95-105$ & 0.49 & $26 \mathrm{hpa}$ & $-10 \mathrm{hpa}$ & 761 \\
& W05/90 & $30-35$ & 0.61 & $299 \mathrm{hpa}$ & $-101 \mathrm{hpa}$ & 582 \\
& & $55-65$ & 0.55 & $218 \mathrm{hpa}$ & $-5 \mathrm{hpa}$ & 582 \\
Throughfall & & $95-105$ & 0.68 & $185 \mathrm{hpa}$ & $-83 \mathrm{hpa}$ & 685 \\
& W05/90 & - & 0.95 & $4.1 \mathrm{~mm}$ & $1.4 \mathrm{~mm}$ & 21 \\
\hline
\end{tabular}




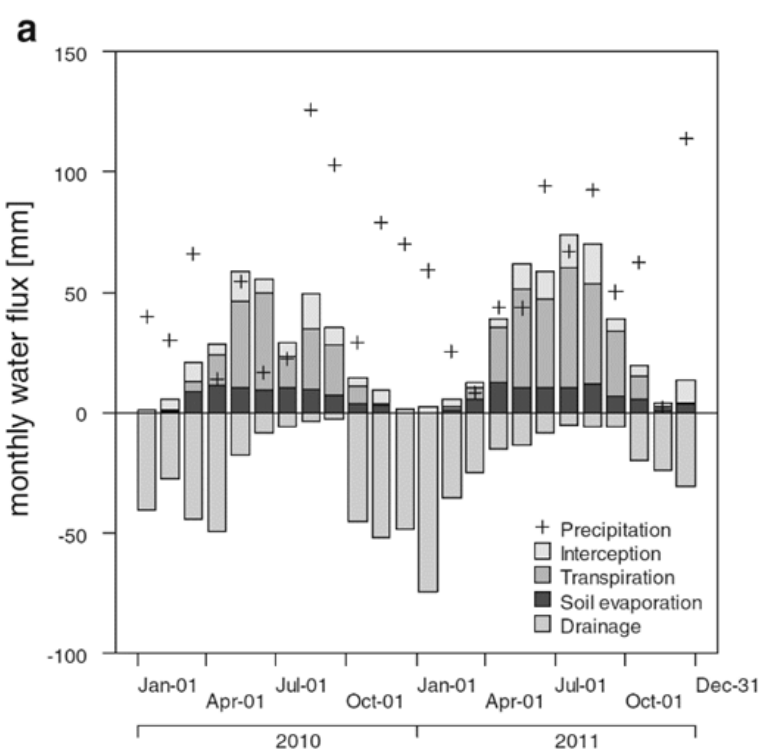

b

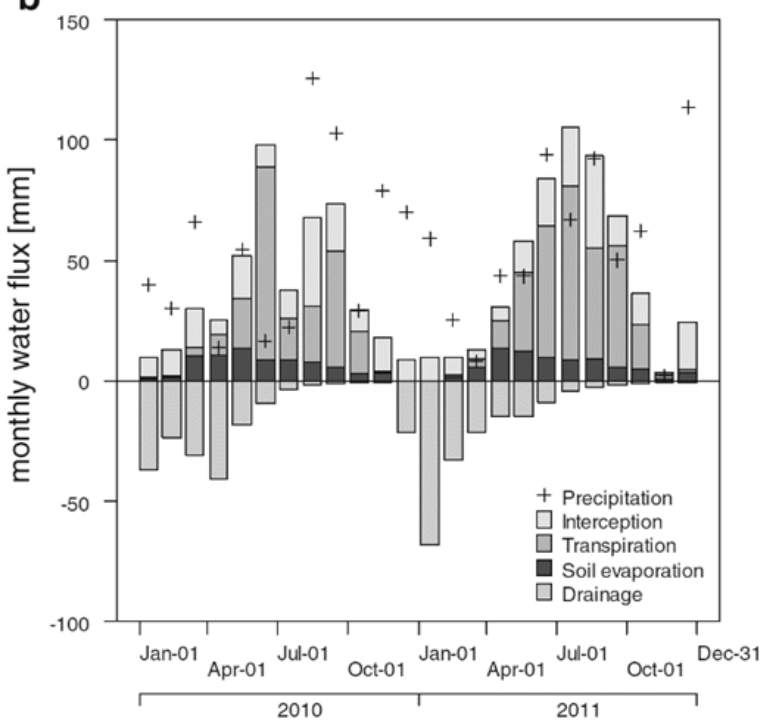

Fig. 3 a, b Simulated monthly water fluxes for Ref (a) and W05/90 (b). Groundwater recharge (drainage) is presented by negative values

Germany is about 12 million ha, where approximately 2.3 million ha is used for bioenergy raw material production [5]. As of today, SRC contribute to only approximately 5,000 ha [50], it may be unrealistic to fill the forecasted wood gap in Germany by using only SRC.

Thus, and in accordance with Fritsche et al. [51], the cultivation of bioenergy crops on natural or semi-natural land that is currently not under specific production, is expected to increase. However, in comparison with conventional crops for bioenergy production (e.g., canola, maize), SRC may even increase ecological services on the field as well as on the landscape level [52-56]. SRC may act as physical barriers in the formation of "arable deserts" and protect against soil erosion or act as riparian or groundwater buffer strips to protect soil and water qualities in the context of the Water Framework Directive 2006/118/EU [57].

Furthermore, the cultivation of biomass on unused degraded land or on abandoned farmland as applied in this study can be seen as a safeguard against negative indirect land use change effects, as described by Fritsche et al. [51].

In the given study, the general focus of the implemented $\mathrm{SRC}$ is to protect drinking water resources from nitrate pollution while simultaneously producing biomass feedstock on an extensive level, i.e., without any further input of $\mathrm{N}$ fertilizers or other chemicals. However, as drinking water is the most important product of land use, groundwater recharge rates have to be considered as well.

According to Gadgil et al. [58], the Fuhrberg recharge zone can thus be described as an "ecologically sensitive area" which is both, ecologically and economically important, but, vulnerable to even mild disturbances and hence demands careful management. In Fuhrberger Feld, reduced nitrate loads were achieved by setting aside arable cropland as demonstrated by the low nitrate leaching measured from the reference plot (Fig. 1).

Nevertheless, is it not clear how sustainable this approach is in the long-run. The $\mathrm{C}$ - and $\mathrm{N}$-rich topsoil horizon is a potential source of nitrate leaching coming from mineralization pulses and accordingly may be vulnerable to any disturbances such as droughts, subsequent rewetting or even fire, all of which lead to a release of organically bound $\mathrm{N}$ sources. Such a disturbance effect can be followed on plot $\mathrm{P} 09 / 90$, where the site preparation measures (deep plowing) were followed by a distinct nitrate pulse in period $\mathrm{A}$ ( $\mathrm{Feb}-$ May 2010). Enhanced amounts of organically bound N sources were made available and subsequently leached as nitrate to the groundwater.

However, nitrate leaching may also exhibit a high temporal variability, as evident from plot W05/90. Here, nitrate concentrations were in the range of the drinking water threshold value of $11.3 \mathrm{mg} \mathrm{NO} 3-\mathrm{N} \mathrm{L}^{-1}$ (i.e., $50 \mathrm{mg} \mathrm{NO3} \mathrm{L}^{-1}$ [27]) during period A, but significantly decreased to the very low level of the reference plot in period B (Dec 2010 to Jun 2011). The same trend was evident for $\mathrm{P} 94 / 30$, though the starting nitrate concentrations were less pronounced (mean in period A, $3.3 \mathrm{mg} \mathrm{L}^{-1}$ ) but also exhibited considerable variability around the mean $( \pm 3.4 \mathrm{SD})$. As the nitrate concentrations in $\mathrm{P} 94 / 30$ were always clearly below the drinking water threshold, it can be concluded that SRC, at least in the long term, do not leach critical amounts of nitrate.

As indicated in Table 4, higher $\mathrm{C}$ and $\mathrm{N}$ contents as well as higher $\mathrm{C} / \mathrm{N}$ ratios are present in the deeper soil horizons 
Table 7 Simulated annual water balances of the Ref and W05/90 study plots, given in $\mathrm{mm}$ and as percentage of precipitation (\% P)

\begin{tabular}{|c|c|c|c|c|}
\hline \multirow{2}{*}{$\begin{array}{l}\text { Water balance } \\
\text { component }\end{array}$} & \multicolumn{2}{|l|}{2010} & \multicolumn{2}{|l|}{2011} \\
\hline & $\begin{array}{l}\text { Ref mm } \\
(\% \mathrm{P})\end{array}$ & $\begin{array}{l}\mathrm{W} 05 / 90 \mathrm{~mm} \\
(\% \mathrm{P})\end{array}$ & $\begin{array}{l}\text { Ref mm } \\
(\% \mathrm{P})\end{array}$ & $\begin{array}{l}\text { W05/90 mm } \\
(\% \mathrm{P})\end{array}$ \\
\hline Precipitation & $651(-)$ & $651(-)$ & $662(-)$ & $662(-)$ \\
\hline Interception evap. & $74(11)$ & $168(26)$ & $85(13)$ & $168(25)$ \\
\hline Transpiration & $161(25)$ & $219(34)$ & $236(36)$ & $293(44)$ \\
\hline Soil evaporation & $73(11)$ & $75(12)$ & $80(12)$ & 77 (12) \\
\hline Drainage & $345(53)$ & $189(29)$ & $264(40)$ & $172(26)$ \\
\hline$\Delta$ Water storage ${ }^{a}$ & $-8(-1)$ & $-2(-0.5)$ & $19(3)$ & $-27(-4)$ \\
\hline
\end{tabular}

${ }^{\text {a }}$ Compared to initial soil water storage at $-60 \mathrm{hPa}$

of the $\mathrm{P} 94 / 30$ plot. This finding might be regarded as a development towards more resilience against mineralization pulses and unwanted releases of $\mathrm{C}$ and $\mathrm{N}$ to the atmosphere and/or water sources.

As we do not know how the nitrate concentrations developed on W94/30 since establishment in 1994, we only can speculate: a few years after SRC establishment, the biological activity of the site will increase compared to the former cropland, due to the continuous input of leaf and root litter with no respective output losses of organic material by harvesting. In addition, different vertical soil structures (such as $\mathrm{C}$ and $\mathrm{N}$ accumulations in deeper soil layers) will develop. The most obvious indication of such development is that normally no leaf litter from the previous autumn can be found in spring and $\mathrm{C}$ and $\mathrm{N}$ is higher in horizons below the plowing depth of $30 \mathrm{~cm}$.

Furthermore, $\mathrm{N}$ sources released by mineralization processes are protected from $\mathrm{N}$-leaching as long as $\mathrm{N}$ uptake by the vegetation cover is balancing the $\mathrm{N}$ release. If plant growth stops for some reason - as it was evident on plot W94/30 - but mineralization processes continue, nitrate leaching may occur. Harvesting may also stop the $\mathrm{N}$ uptake. But, since this is done normally during winter, when mineralization rates are low and the rootstock immediately resprouts once the weather gets warmer, nitrification pulses after harvest are not described so far, even in cases with additional $\mathrm{N}$ fertilization [59-61].

Comparable field data of nitrate leaching under SRC without additional $\mathrm{N}$ input manipulation ( $\mathrm{N}$ fertilization, sewage sludge, waste water or compost additions) are rare. However, in one comparable study, Goodlass et al. [60] found enhanced nitrate leaching under a Salix viminals $\mathrm{SRC}$, after the former canola field was plowed in winter and sprayed with herbicides in the following spring. Peak nitrate concentrations reached a maximum of $70 \mathrm{mg} \mathrm{NO} 3^{-}$ $\mathrm{N} \mathrm{L}^{-1}$ in spring and were even enhanced to $134 \mathrm{mg} \mathrm{NO}_{3}$ $\mathrm{N} \mathrm{L}^{-1}$ during the following autumn. Once the SRC was established, concentrations returned to a lower level (18 mg $\mathrm{NO}_{3}-\mathrm{N} \mathrm{L}^{-1}$ ) and were only slightly affected by harvesting operations and annual applications of nitrogen during the first 3 years. The reference plot was an adjacent arable area where nitrate peaks ranged from 26 to $77 \mathrm{mg} \mathrm{NO} \mathrm{NO}_{3}-1$ with an average value of $54 \mathrm{mg} \mathrm{NO}_{3}-\mathrm{N} \mathrm{L}^{-1}$ during the crop rotation. Thus it was concluded, that once established, the risk of nitrate leaching from SRC grown at recommended $\mathrm{N}$ inputs is small, especially when compared with the nitrate peaks in autumn, which are typical of arable rotations [60]. Moreover, significant losses during establishment of stands would be offset by smaller losses during the productive phase, when compared to average nitrate losses from crop production systems [60].

\section{Land Use-Specific Water Budgets}

The water balance simulations for the Ref and W05/90 study plots revealed distinct differences in partitioning precipitation into $E_{i}, T_{a}$ and groundwater recharge. The differences in water budget partitioning are not surprising and generally agree with the findings of Persson [24], who compared the water budgets of different vegetation types and found highest evapotranspiration rates for spruce and willow and lowest for grassland and barley. However, considering the whole observation period, groundwater recharge from the willow stand was reduced by approximately $40 \%\left(120 \mathrm{~mm} \mathrm{a}^{-1}\right)$ compared to the reference site. This is comparable to values for deciduous forests at comparable sites [62], but groundwater recharge from W05/90 was higher than values reported for coniferous forests [63] located at Fuhrberger Feld. The reduction thus is smaller than the reduction reported by Persson [24] for comparable land uses and reflects the need for water balance studies including various sites and different meteorological conditions. Furthermore, studies about the water balance of willow SRC on sandy soils with low amounts of plant available soil water storage are scarce in literature and data covering the whole year and not only the growing season are even scarcer.

Groundwater recharge from the willow stand was considerably reduced in comparison with the reference plot. The main reason for this shift from groundwater recharge to evapotranspiration lies in doubled interception losses, which are caused by a closer coupling of SRC stands to the atmosphere [38]. This implies that evapotranspiration rates are mainly controlled by atmospheric vapor pressure deficit and aerodynamic resistance and less by available radiation energy [64]. Together with a higher interception storage capacity of the willow canopy, simulated interception was approximately $25 \%$ of annual precipitation in both years. This amount lies between two extremes reported by Persson and Lindroth [38] (11\%) and Ettala [65] (31\%).

It is surprising that during both years, the willow stand intercepted the same amount of rainfall $(170 \mathrm{~mm}$, Table 7$)$ at nearly the same annual sum of precipitation, despite the fact 
that the stand was harvested in spring 2011. Re-sprouting stands are in the first half of the growing season less well coupled to the atmosphere because of their low stand height [38]. Additionally, leaf area development is delayed compared to a mature stand. This implies a lower canopy interception storage capacity and before canopy closure, a higher amount of precipitation directly reaches the ground. Thus, it is conceivable that the harvested willow stand intercepts relatively less rainfall than a mature stand, and the lack of differences between the years is due to a different temporal distribution of rainfall. In fact, a simulation scenario that assumes a mature instead of a re-sprouting willow stand under the climate conditions of 2011 yields interception losses increased by $25 \mathrm{~mm}$. In turn, a re-sprouting stand under the 2010 climate conditions has $15 \mathrm{~mm}$ less interception evaporation per year.

Aside from interception evaporation, transpiration rates from the willow stand are as well higher than transpiration rates from the reference site. With a deeper rooting system, the willow stand draws water from a greater soil volume, thus more water is available for transpiration. In both years, annual transpiration from the willow stand was approximately $60 \mathrm{~mm}$ higher compared to the reference site. This amount complies well with the surplus of plant available soil water resources. Tensiometer time series (Fig. 2b) indicate that the investigated willow SRC is able to evapotranspirate all precipitation that falls during the growing season (also see [18]) and additionally develops pronounced soil water deficits. These soil water deficits-being about $60 \mathrm{~mm}$ higher compared to the reference plot-in turn reduce the groundwater recharge, as the soil needs to be rewetted before drainage can take place.

A consequence of the willows' high water demand in combination with the relatively low soil water storage capacity of the sandy soils is the exposition to water stress during periods with low amounts of precipitation. This is exactly what the simulation suggested in July 2010, when transpiration collapsed (Fig. 3b) because of exhausted soil water supplies in the root zone. Typical reactions to water stress are leaf shedding [66, 67] and yield losses [18]. Leaf shedding was actually observed on the study plot in July 2010. Yield was not monitored during or immediately after the drought, but mean annual dry mass production at the end of the year 2009 was approximately $5.7 \mathrm{Mg} \mathrm{ha}^{-1}$ [28]. This value is relatively low for willow SRCs [18] and indicates that growth conditions are not optimal in the Fuhrberger Feld, likely due to repeated water shortage.

Higher amounts of plant available soil water, either due to a higher soil water storage capacity as found in loamy soils, a greater rooting depth or even direct access to groundwater help to bridge extended dry periods and in terms of yield lead to more robust SRC production systems. However, this increased robustness is at the expense of groundwater recharge, since the soil water storage has to be refilled before drainage can form. Therefore, it can be concluded, that on sites with low plant available soil water capacity and where roots have no access to the water table, a change in land use from fallow to SRC indeed will have a negative impact on groundwater recharge. But on such sites, this impact is, as long as SRCs do not have access to groundwater, moderate: The soil water storage capacity sets a minimum level for groundwater recharge, but also sets the maximum limit to yield.

\section{$\mathrm{N}$ released by Nitrate Leaching}

Nitrate fluxes from the reference (Ref) and the willow (W05/90) plot (Table 8) were calculated from the simulated drainage fluxes. Mean concentrations for all sampling dates were multiplied with the corresponding drainage flux during the sampling interval, nitrate fluxes were cumulated separately for periods A (Feb 2010 to May 2010) and B (Dec 2010 to June 2011). In order to obtain an estimate of the annual nitrate output rate for the year 2010, nitrate seepage concentrations for the months Sep to Nov 2010, where considerable amounts of drainage from Ref took place but concentration measurements were missing, were assumed to be the same as in Dec 2010. For the summer months in 2010, when also no samples could be taken and only minimal drainage occurred, the concentrations measured in May were used to calculate the nitrate flux.

In total, the W05/90 plot lost $16.5 \mathrm{~kg} \mathrm{NO}_{3}-\mathrm{N} \mathrm{ha}^{-1} \mathrm{a}^{-1}$ in 2010 (Table 8), where $87 \%$ of the losses happened during winter/spring 2010. Nitrate leaching from the reference plot (Ref) was less than a tenth (1.36 kg of $\left.\mathrm{NO}_{3}-\mathrm{N} \mathrm{ha}^{-1} \mathrm{a}^{-1}\right)$ of the amount of the SRC plot. Eighty percent of the annual leaching from Ref occurred during winter and spring 2010.

Calculated nitrate leaching losses for the W05/90 plot are slightly higher than reported in previous studies [59, 61]. There, leaching rates were between zero and slightly less than $2 \mathrm{~kg} \mathrm{ha}^{-1} \mathrm{a}^{-1}$, despite long-term repeated annual nitrogen fertilization of more than $150 \mathrm{~kg} \mathrm{ha}^{-1} \mathrm{a}^{-1}$ [59]. However, our rates were about 10 times lower than rates cited by Aronsson and Bergström [59] for the first year after establishment, when

Table 8 Cumulated drainage water fluxes and nitrate leaching loss ( \pm SD) for the Ref and $\mathrm{W} 05 / 90$ study plots during sampling periods A (Feb 2010-May 2010) and B (Dec 2010 -June 2011), as well as the annual sum for 2010

\begin{tabular}{llllll}
\hline & \multicolumn{2}{l}{ Drainage flux $\left(\mathrm{L} \mathrm{m}^{-2}\right)$} & & \multicolumn{2}{l}{ Nitrate leaching $\left(\mathrm{kg} \mathrm{ha}^{-1}\right)$} \\
\cline { 2 - 3 } \cline { 5 - 6 } \cline { 5 - 6 } & Ref & W05/90 & & Ref & W05/90 \\
\hline Period A & 171 & 143 & & $1.08 \pm 0.85$ & $14.3 \pm 6.55$ \\
Period B & 216 & 180 & & $0.42 \pm 0.38$ & $2.03 \pm 1.46$ \\
Jan-Dec 2010 & 345 & 189 & & $1.36 \pm 1.08$ & $16.5 \pm 7.95$ \\
\hline
\end{tabular}


willow was cultivated in lysimeters, highly fertilized and irrigated on sandy soils ( $\left.140 \mathrm{~kg} \mathrm{NO}_{3}-\mathrm{N} \mathrm{ha}^{-1} \mathrm{a}^{-1}\right)$. Similar $\mathrm{N}$ loss with seepage of $90 \mathrm{~kg} \mathrm{NO}-\mathrm{N} \mathrm{ha}^{-1} \mathrm{a}^{-1}$ were measured by Dimitriou and Aronsson [68] from a lysimeter experiment, where irrigated willows in sandy soil were fertilized with $320 \mathrm{~kg}$ of $\mathrm{N} \mathrm{ha}^{-1}$ in form of sewage sludge. These losses occurred within a time span of 6 months (May to Oct) and were mainly attributed to the high $\mathrm{N}$ fertilizer input and not to the chemical composition of the fertilizers. As in our study, almost $90 \%$ of the annual leaching from the W05/90 plot happened during the winter/spring 2010 there might be some site specific but until now unknown reason for a relatively high leaching flush. No direct $\mathrm{N}$ input by fertilization or any comparable input occurred and possible mineralization artifacts potentially produced by the installation of the suction lysimeters can also be excluded, since they were installed 4 months earlier.

Increased nitrate leaching may also favor $\mathrm{N}_{2} \mathrm{O}$ emissions [69]. As part of a Diploma thesis, a series of five $\mathrm{N}_{2} \mathrm{O}$ measurement campaigns between June and Oct 2010 was conducted on all plots, except for W94/30 [70]. Results indicate that $\mathrm{N}_{2} \mathrm{O}$ emissions increased after heavy rainfalls at the end of August and in September 2010 at the P09/90 plot. Here, maximum mean values in August reached emissions of 65.0 $( \pm 20.5 \mathrm{SD}) \mu \mathrm{g} \mathrm{N} \mathrm{N}_{2} \mathrm{O}-\mathrm{N} \mathrm{m}^{-2} \mathrm{~h}^{-1}$, but values fell back to a baseline of below $20 \mu \mathrm{g} \mathrm{N}_{2} \mathrm{O}-\mathrm{N} \mathrm{m}^{-2} \mathrm{~h}^{-1}$ in October 2010 again. However, also the reference plot showed peak values during this period (August 2010: 43.5 $\pm 18.6 \mathrm{SD} \mu \mathrm{g} \mathrm{N} \mathrm{N}_{2} \mathrm{O}$ $\mathrm{N} \mathrm{m}^{-2} \mathrm{~h}^{-1}$ ), whereas the W05/90 and P94/30 plots never had higher emissions than $20 \mu \mathrm{g} \mathrm{N} \mathrm{N}_{2} \mathrm{O}-\mathrm{N} \mathrm{m}^{-2} \mathrm{~h}^{-1}$ [70]. In agreement with other studies [71, 72], it is concluded that SRC, once established, emit considerably less $\mathrm{N}_{2} \mathrm{O}$, compared to other bioenergy crops or even less than fallow grounds [70]. Estimated annual emission rates for the established SRC plots in the Fuhrberger Feld were below $1 \mathrm{~kg} \mathrm{ha}^{-1} \mathrm{a}^{-1}[70]$.

\section{Conclusions}

Former cropland which was abandoned due to protection reasons of nitrate pollution in lowland drinking water catchment areas can well be used for the cultivation of SRC to increase the land use value by the production of woody biomass. Our results showed that in SRCs of willow and poplar clones with different age (2-17 years) and different soil preparation measures (standard and deep plowing), the mean nitrate concentrations in $100 \mathrm{~cm}$ soil depth with few exceptions stays below the drinking water threshold value of $10.3 \mathrm{mg} \mathrm{NO} \mathrm{N} \mathrm{L} \mathrm{L}^{-1}$. There are two stages, where relatively increased amounts of nitrate might be leached from SRC cultivations, i.e., (1) when SRC are newly installed and intensive or even deep plowing was applied before cultivation (example P09/90) and (2) when the sink, respectively the export function for $\mathrm{N}$ compounds by tree uptake and harvesting measures is offset (example W94/30). Harvesting itself obviously did not initiate a nitrate flush, but nitrate release from an over-aged, never harvested willow stand was significantly increased.

Furthermore, we conclude that groundwater recharge rates, which are also of concern in drinking water sanctuaries, were not excessively reduced by SRC cultivations. Soils with low amounts of plant available soil water storage capacity and high permeability, as often found in lowland drinking water catchment areas, set a minimum level for groundwater recharge by limiting transpiration, as long as roots have no access to the groundwater table. Thus, less precipitation is needed to refill the soil water storage than on soils with higher water storage capacity, and groundwater recharge begins earlier after transpiration ceases in autumn.

Another finding, which needs more investigation though, might provide an opportunity to manipulate the water balance of SRC stands by management. Less interception loss can be expected from stands during the first year after harvested and thus higher groundwater recharge rates might be obtained by choosing a shorter rotation cycle, as the stand then is more often in the resprouting state.

Acknowledgments The authors are grateful to the Hanover water authorities (Stadtwerke Hannover AG; www.enercity.de), to the Agency for Renewable Resources (FNR e.V;. www.fnr.de) and to the European ERA-NET-Bioenergy program (www.eranetbioenergy.net) for funding this study. We give our special thanks to D. Böttger for his field assistance, P.-E. Jansson for his valuable hints and suggestions concerning the water balance simulations and O. van Straten for correcting grammar and spelling of the manuscript.

Open Access This article is distributed under the terms of the Creative Commons Attribution License which permits any use, distribution, and reproduction in any medium, provided the original author(s) and the source are credited.

\section{References}

1. IEA (2010) IEA statistics-renewables information 2010. Technical report. IEA, Paris, p 446

2. European Council (2009) Directive 2009/28/EC of the European Parliament and of the Council of 23 April 2009 on the promotion of the use of energy from renewable sources and amending and subsequently repealing Directives 2001/77/EC and 2003/30/EC. Technical report

3. EEA (2006) How much bioenergy can Europe produce without harming the environment? Technical report. European Environment Agency, Copenhagen

4. European Union (2007) The impact of a minimum $10 \%$ obligation for biofuel use in the EU-27 in 2020 on agricultural markets. Technical report

5. FNR (2011) www.nachwachsenderohstoffe.de/service/daten-undfakten/anbau, access: 21.11.2011. Technical report, Fachagentur Nachwachsende Rohstoffe e.V. (FNR), 18276 Gülzow-Prüzen, Germany 
6. Don A, Osborne B, Hastings A, Skiba U, Carter MS, Drewer J et al (2011) Land-use change to bioenergy production in Europe: implications for the greenhouse gas balance and soil carbon. GCB Bioenergy 4(4):372-391

7. Djomo SN, Kasmioui OE, Ceulemans R (2011) Energy and greenhouse gas balance of bioenergy production from poplar and willow: a review. GCB Bioenergy 3(3):181-197

8. Buhler DD, Netzer DA, Riemenschneider DE, Hartzler RG (1998) Weed management in short rotation poplar and herbaceous perennial crops grown for biofuel production. Biomass Bioenergy 14 (4):385-394

9. Otto S, Loddo D, Zanin G (2010) Weed-poplar competition dynamics and yield loss in italian short-rotation forestry. Weed Res 50(2): 153-162

10. Röhle H, Böcker L, Feger K-H, Petzold R, Wolf H, Ali W (2008) Anlage und Ertragsaussichten von Kurzumtriebsplantagen in Ostdeutschland. Schweiz Z Forstwes 159:133-139

11. Crutzen PJ, Mosier AR, Smith KA, Winiwarter W (2008) $\mathrm{N}_{2} \mathrm{O}$ release from agro-biofuel production negates global warming reduction by replacing fossil fuels. Atmos Chem Phys 8 (2):389-395

12. Well R, Butterbach-Bahl K (2010) Indirect emissions of nitrous oxide from nitrogen deposition and leaching of agricultural nitrogen. In: Smith K (ed) Nitrous oxide and climate change. Earthscan Publications Ltd., Sterling, UK, p 162

13. Pape JC (1970) Plaggen soils in the Netherlands. Geoderma $4: 229255$

14. Springob G, Brinkmann S, Engel N, Kirchmann H, Böttcher J (2001) Organic C levels of Ap horizons in north german pleistocene sands as influenced by climate, texture, and history of landuse. J Plant Nutr Soil Sci 164:681-690

15. Springob G, Kirchmann H (2010) Ratios of carbon to nitrogen quantify non-texture-stabilized organic carbon in sandy soils. J Plant Nutr Soil Sci 173(1):16-18

16. Köhler K, Duijnisveld WHM, Böttcher J (2006) Nitrogen fertilization and nitrate leaching into groundwater on arable sandy soils. J Plant Nutr Soil Sci 169:185-195

17. Petzold R, Schwärzel K, Feger K-H (2011) Transpiration of a hybrid poplar plantation in saxony (Germany) in response to climate and soil conditions. Eur J For Res 130:695-706

18. Lindroth A, Båth A (1999) Assessment of regional willow coppice yield in Sweden on basis of water availability. For Ecol Manag 121 (1-2):57-65

19. Grip H, Halldin S, Lindroth A (1989) Water use by intensively cultivated willow using estimated stomatal parameter values. Hydrol Process 3(1):51-63

20. Hall RL, Allen SJ, Rosier PTW, Hopkins R (1998) Transpiration from coppiced poplar and willow measured using sap-flow methods. Agric For Meteorol 90:275-290

21. Knur L, Murach D, Murn Y, Bilke G, Muchin A, Grundmann P, et al. (2007) Potentials, economy and ecology of a sustainable supply with wooden biomass. In: From research to market development: 15th European Biomass Conference \& Exhibition proceedings of the international conference held in Berlin

22. Lamersdorf N, Schulte-Bisping H (2010) Zum Wasserhaushalt von Kurzumtriebsplantagen. Archiv für Forstwesen und Landschaftsökologie 44:23-29

23. Lindroth A, Verwijst T, Halldin S (1994) Water-use efficiency of willow: variation with season, humidity and biomass allocation. $\mathrm{J}$ Hydrol 156(1-4):1-19

24. Persson G (1997) Comparison of simulated water balance for willow, spruce, grass ley, and barley. Nord Hydrol 28:85-89

25. Dimitriou I, Busch G, Jacobs S, Schmidt-Walter P, Lamersdorf N (2009) A review of the impacts of short rotation coppice cultivation on water issues. vTI Agric For Res 3:197-206
26. Jansson P-E, Karlberg L (2004) Coupled heat and mass transfer model for soil-plant-atmosphere systems. Technical report, Royal Institute of Technolgy, Dept of Civil and Environmental Engineering Stockholm, Stockholm. ftp://www.lwr.kth.se/CoupModel/ CoupModel.pdf

27. TrinkwV (2011) Trinkwasserverordnung (TrinkwV) Deutschland, in der Fassung der Bekanntmachung vom 28. (BGB1. I S. 2370), 2001

28. Techtmann C (2010) Wuchsleistung von Weiden und Pappeln im Kurzumtrieb auf ertragsschwachen Standorten. Master's thesis, University of Göttingen

29. ICP (2004) Subprogramm sw: soil water chemistry. Technical report, ICP

30. Fürst A (2012) 14th needle/leaf interlaboratory comparison test 2011/2012. Technical report

31. ICP (2011) ICP Waters Report 107/2011, Intercomparison 1125. Technical report, ICP

32. Schlichting E, Blume HP, Stahr K (1995) Bodenkundliches Praktikum. Blackwell Wissenschaft, Berlin

33. Wegehenkel M (2005) Validation of a soil water balance model using soil water content and pressure head data. Hydrol Process 19 (6): 1139-1164

34. Pinheiro JC, Bates DM (2000) Linear mixed effects models in S and S-PLUS, chapter linear mixed effects models. Springer, Berlin, pp 3-56

35. Akaike H (1973) Information theory and an extension of maximum likelihood principle. In: Petrov BN, Csaki F (eds) Second international symposium on information theory, vol 1. Akademiai Kiado, Budapest, pp 267-281

36. Pinheiro JC, Bates DM, DebRoy S, Sarkar D, R Development Core Team (2012) NLME: linear nonlinear mixed effect model $3: 1-103$, R package version

37. $\mathrm{R}$ Development Core Team. R: a language and environment for statistical computing. R Foundation for Statistical Computing, Vienna, Austria, 2011. URL http://www.R-project.org/. ISBN 3900051-07-0

38. Persson G, Lindroth A (1994) Simulating evaporation from shortrotation forest: variations within and between seasons. J Hydrol $156(1-4): 21-45$

39. Heidmann T, Thomsen A, Schelde K (2000) Modelling soil water dynamics in winter wheat using different estimates of canopy development. Ecol Model 129:229-243

40. Christiansen JR, Elberling B, Jansson P-E (2006) Modelling water balance and nitrate leaching in temperate Norway spruce and beech forests located on the same soil type with the CoupModel. For Ecol Manag 237(1-3):545-556

41. Jansson P-E, Cienciala E, Grelle A, Kellner E, Lindahl A, Lundblad M (1999) Simulated evapotranspiration from the Norunda forest stand during the growing season of a dry year. Agric For Meteorol 98-99:621-628

42. Lundmark A (2008) Monitoring transport and fate of de-icing salt in the roadside environment-Modelling and field measurements. $\mathrm{PhD}$ thesis, Kungliga Tekniska högskolan-Land and Water Resources Engineering, Stockholm

43. Brooks RH, Corey AT (1966) Properties of porous media affecting fluid flow. J Irrig Drain Div Proc Am Soc Civ Eng (IR2) 92:61-88

44. Mualem Y (1976) A new model for predicting the hydraulic conductivity of unsaturated porous media. Water Resour Res $12: 513-522$

45. Monteith JL (1965) Evaporation and environment. Symp Soc Exp Biol 19:205-224

46. Lindroth A (1985) Canopy conductance of coniferous forests related to climate. Water Resour Res 21:297-304

47. Shaw RH, Pereira AR (1982) Aerodynamic roughness of a plant canopy: a numerical experiment. Agric Meteorol 26:51-65 


\section{Chapter 3}

Transpiration and water use strategies of a young and a full-grown short rotation coppice differing in canopy closure and leaf area

Paul Schmidt-Walter, Falk Richter, Mathias Herbst, Bernhardt Schuldt, Norbert P. Lamersdorf

Published Journal Article, Agricultural and Forest Meteorology (2014) 195-196:165-178 https://doi.org/10.1016/j.agrformet.2014.05.006 


\section{Transpiration and water use strategies of a young and a full-grown short rotation coppice differing in canopy cover and leaf area}

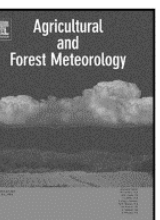

Paul Schmidt-Walter ${ }^{\mathrm{a}, *}$, Falk Richter ${ }^{\mathrm{a}}$, Mathias Herbst ${ }^{\mathrm{b}}$, Bernhard Schuldt ${ }^{\mathrm{c}}$, Norbert P. Lamersdorf ${ }^{\mathrm{a}}$

a Department of Soil Science of Temperate Ecosystems, University of Göttingen, Büsgenweg 2, 37077 Göttingen, Germany

${ }^{b}$ Department of Bioclimatology, University of Göttingen, Büsgenweg 2, 37077 Göttingen, Germany

'Department of Plant Ecology and Ecosystem Research, University of Göttingen, Griesebachstraße 1, 37077 Göttingen, Germany

\section{A R T I C L E I N F O}

\section{Article history:}

Received 25 July 2013

Received in revised form 24 February 2014 Accepted 8 May 2014

\section{Keywords:}

Short rotation

Transpiration

Canopy conductance

Isohydric

Poplar

\begin{abstract}
A B S T R A C T
In order to evaluate the influence of canopy cover and leaf area on the water use of short rotation coppices (SRC), we measured evapotranspiration and transpiration of a young and a full-grown mature poplar SRC throughout one growing season, using the Bowen-ratio energy balance method and sap flux technique, respectively. The young SRC at Fuhrberg had a sparse though developing canopy reaching a maximum leaf area index (LAI) of $3.8 \mathrm{~m}^{2} \mathrm{~m}^{-2}$ in August, while the mature SRC at Großfahner earlier reached maximum LAI at $7.4 \mathrm{~m}^{2} \mathrm{~m}^{-2}$. Despite contrasting canopy densities, growing season total evapotranspiration (Fuhrberg: $380 \mathrm{~mm}$, Großfahner: $445 \mathrm{~mm}$ ) and transpiration ratios did not differ substantially, because understorey transpiration and soil evaporation probably compensated low tree transpiration in the first half of the growing season at $\mathrm{LAI}<3 \mathrm{~m}^{2} \mathrm{~m}^{-2}$. Mid-season mean daily transpiration on rainless days was $2.34 \pm 0.13 \mathrm{~mm} \mathrm{~d}^{-1}$ at Fuhrberg and $3.16 \pm 0.81$ at Großfahner. The values for the full-grown SRC at Großfahner were in the middle range of reported values for poplar SRCs of comparable LAI and canopy density, and came from efficient stomatal regulation of transpiration, in which poplar clones might differ. Bulk canopy conductance $\left(g_{c}\right)$, calculated by inverting the Penman-Monteith equation and related to vapor pressure deficit $(D)$, revealed stomatal control of transpiration at the mature plantation, and according to a simple hydraulic model, was sufficient to maintain a minimum leaf water potential at high atmospheric demand. This indicated isohydric behavior and marks a conservative water use strategy, which avoids water stress by limiting transpiration rates at high $D$ and might be typical for the investigated poplar hybrid (J-105). The young plantation exhibited a similar water use strategy, when LAI was above $3 \mathrm{~m}^{2} \mathrm{~m}^{-2}$. Before canopy closure, the ratio of stomatal sensitivity $(m)$ and reference conductance ( $g_{\text {cref }}$, i.e. $g_{c} @ D=1 \mathrm{kPa}$ ), which are parameters of a logarithmical response curve of $g_{c}$ to $D$, was significantly lower than the theoretical ratio for isohydric responses. This indicates poor stomatal control of water loss and reflected the contribution of understorey-transpiration and soil evaporation to total stand evapotranspiration, which might increase severely at high evaporative demand in sparse poplar stands.
\end{abstract}

All rights reserved.

\section{Introduction}

Short rotation coppices (SRC) with fast-growing tree species like poplar (Populus ssp.) and willow (Salix ssp.), cultivated for woody biomass production, provide a sustainable way to replace fossil fuels and mitigate greenhouse gas (GHG) emissions. Experts therefore recommend SRCs to become part of an overall strategy to achieve the minimum target of GHG emission reduction as required by the EU Renewable Energy Directive (Djomo et al.,

\footnotetext{
* Corresponding author. Tel.: +4955169401166.

E-mail address: paul.schmidt-walter@nw-fva.de (P. Schmidt-Walter).
}

2011). Anyhow, if area requirements for woody biomass production increase significantly, environmental impacts of large-scale cultivations have to be taken into consideration.

Extensive research on SRC water use in Sweden, England and other countries across climatic gradients revealed substantially higher evapotranspiration of SRC than conventional agricultural crops, which they might replace. Daily transpiration rates can be as high as $7-10 \mathrm{~mm} \mathrm{~d}^{-1}$ (Allen et al., 1999; Hall et al., 1998; Persson and Lindroth, 1994), thereby exceed crop reference evaporation and water use of deciduous forests (Roberts, 1983; Stephens et al., 2001). In some cases, excessive transpiration rates are facilitated by high stomatal conductance that is maintained even during periods of high vapor pressure deficits, imposing little restriction to 
evaporative demand (Hall et al., 1998). Where pedo-climatic conditions are favorable, these transpiration rates can be sustained over long rainless periods with the help of a deep rooting system, that enables SRCs to tap large soil volumes and available groundwater resources (Zhang et al., 1999). Rainfall interception of SRCs is also increased compared to conventional agricultural crops (Dimitriou et al., 2009), therefore negative impacts on aquifer recharge and stream flow have to be expected where short rotation forests replace conventional arable crops in a large scale (Petzold et al., 2011).

However, transpiration rates comparable to or lower than crop reference evaporation are also documented (Fischer et al., 2013; Linderson et al., 2007; Meiresonne et al., 1999; Zhang et al., 1999) and the variability in reported SRC water use rates is high. The extent of negative hydrological effects from the high water use highly depends on individual climate conditions and soil water availability (Dimitriou et al., 2009) that determine evaporative demand and water supply. Water availability often is also the main growth limiting factor for poplar and willow plantations (Jug et al., 1999; Linderson et al., 2007; Lindroth and Båth, 1999). For an economically beneficial and ecologically sustainable production of woody biomass, it is therefore crucial to carefully select adequate production sites. Moreover, if area requirements increase, additional factors have to be identified to increase the water-efficiency of short rotation coppices by management (King et al., 2013).

Aside from careful site selection, management practices seem to influence SRC water use and might hold potential to increase water-efficiency of short rotation forestry. Management schemes with longer rotation periods that allow for the development of dense canopies with high leaf area are generally suspected to use more water than plantations with shorter rotation periods, where trees are coppiced before developing a dense canopy (Busch, 2009; Persson and Lindroth, 1994; Petzold et al., 2011). However, most field studies on SRC water use were conducted in full-grown mature plantations and to our knowledge there is currently a lack of reports addressing the water use of young SRCs during an early phase of stand development, e.g. at low leaf area before canopy closure.

Another factor for SRC water use that is amenable to management seems to be the choice of plant material. Some woody species cultivated in short rotation display a wide range of physiological mechanisms to regulate transpiration in response to environmental variables. Poplars (Populus sp.) are generally considered to be drought-avoiding, isohydric tree species (Tardieu and Simonneau, 1998) that efficiently control transpiration by stomatal regulation in response to atmospherical and soil drought (Tardieu and Simonneau, 1998). Notwithstanding, this rather conservative, water-saving strategy may not apply to all poplar hybrids. More drought-tolerant, anisohydric water use strategies are also reported from greenhouse experiments (Ceulemans et al., 1988; Larchevêque et al., 2011), and an intraspecific variability of the water use strategy and drought-resistance of poplars is recognized (Almeida-Rodriguez et al., 2010). Anisohydric behavior is characterized by loose stomatal control of transpiration and dropping leaf water potentials under moderate drought. On the one hand, this anisohydric strategy allows for high photosynthetic activity and thus biomass production under atmospheric and soil drought, but also results in high water use and increases the risk of fatal xylem cavitations under severe drought. However, the variability in poplar water use strategy was found on potted plants and might be far from how things actually work at the field scale, and water use strategies have yet not been addressed at the canopy level in European poplar hybrids.

Within this context, we analyzed water use patterns and water use strategy of an uncoppiced young (third growing season) poplar plantation at the onset of canopy closure, and a high-density mature (sixth growing season) plantation with a dense canopy and high leaf
Table 1

Stand and site characteristics of the study plots.

\begin{tabular}{|c|c|c|}
\hline & Fuhrberg & Großfahner \\
\hline Location & $52^{\circ} 35^{\prime} \mathrm{N}, 9^{\circ} 49^{\prime} \mathrm{E}$ & $51^{\circ} 30^{\prime} \mathrm{N}, 10^{\circ} 49^{\prime} \mathrm{E}$ \\
\hline Elevation (m) & 37 & 189 \\
\hline $\begin{array}{l}\text { Mean annual } \\
\text { temperature and } \\
\text { rainfall }\left({ }^{\circ} \mathrm{C}, \mathrm{mm}\right)\end{array}$ & $8.9,677$ & $9.4,549$ \\
\hline Size (ha) & 3.8 & 0.6 \\
\hline $\begin{array}{l}\text { Cultivated poplar } \\
\text { clones }\end{array}$ & $\begin{array}{l}\text { "Max 1", } \\
\text { "Androscoggin", "AF2" }\end{array}$ & “Japan J-105" \\
\hline $\begin{array}{l}\text { Distance between } \\
\text { plants/(double) rows } \\
(\mathrm{m})\end{array}$ & $0.65 /(0.8) 2$ & $0.5 / 0.75$ \\
\hline $\begin{array}{l}\text { Actual plant density } \\
\left(\mathrm{Nha}^{-1}\right)\end{array}$ & 12750 & 9454 \\
\hline Soil texture & Sand/loamy sand & Silt loam \\
\hline $\mathrm{PAW}^{\mathrm{a}}(\mathrm{mm})$ & 160 & 205 \\
\hline Groundwater level & $3.8-4.5$ & $1.8-2.7$ \\
\hline $\begin{array}{l}\text { Shoot age/stool age } \\
\text { (years) }\end{array}$ & $2 / 2$ & $5 / 5$ \\
\hline Stand height ( $\mathrm{m}$ ) & 2.5 & 9.5 \\
\hline $\begin{array}{l}\text { Maximum leaf area } \\
\text { index }\left(\mathrm{m}^{2} \mathrm{~m}^{-2}\right)\end{array}$ & 3.8 & 7.4 \\
\hline
\end{tabular}

a PAW: plant available soil water capacity (soil water storage between $\mathrm{pF} 1.8$ and pF 4.2 in $0-100 \mathrm{~cm}$ soil depth).

area. With the overall aim to aid in developing adaptive, sustainable management strategies for woody biomass production systems, considering the trade-off between production and water consumption of SRCs, the first objective of this paper was to evaluate the influence of canopy cover and leaf area on SRC water use. These traits can vary with management and might thus provide means to manipulate SRC water use. The second objective was to characterize water use strategies of some widely used hybrid poplars (e.g. “J-105", P. nigra $\times$ P. maximowiczii). The water use strategy can vary among poplar hybrids and has implications on productivity and water use of individual poplar hybrids growing under individual pedo-climatic conditions. Information on individual water use behavior of poplar hybrids would thus help to select adequate plant material for specific sites, under consideration of water management aspects.

To address both objectives, we used the Bowen-ratio energy balance method and sap flux techniques (Granier-type thermal dissipation probes; TDP) to estimate canopy transpiration $\left(E_{\mathrm{t}}\right)$, from which we calculated canopy conductance $\left(g_{c}\right)$. To compare the water use potential of the plantations, we used the empirical description of the stomata closure reaction (i.e. the stomatal sensitivity) to increasing vapor pressure deficit $(D)$ introduced by Oren et al. (1999). This description is based on a reference conductance at low $D$ ( $g_{\text {cref }}$, i.e. $\left.g_{\mathrm{c}} @ 1 \mathrm{kPa}\right)$, that facilitates comparisons of water use among plant stands and seasons. Additionally, it allows inferences on the water use strategy (isohydric or anisohydric) of the investigated plant stands, via the link to a simple hydraulic model.

\section{Material and methods}

\subsection{Study sites}

In our study, two poplar SRCs with different plant age, contrasting stand structure and leaf area were investigated. Some site and stand characteristics are listed in Table 1. Our young poplar plantation (hereafter called "Fuhrberg") is located about $40 \mathrm{~km}$ northeast of Hanover in the lowland drinking water catchment "Fuhrberger Feld" (elevation: $37 \mathrm{~m}$ asl.). At Fuhrberg, we measured evapotranspiration during the growing season 2011 using the Bowen-ratio energy balance(BREB) method. The plantation was established 2009 from cuttings in a double row planting scheme 
(Table 1), on a former arable field (size $4 \mathrm{ha}$ ) that was set aside in the early 1990s due to groundwater protection reasons. A detailed site description can be found in Schmidt-Walter and Lamersdorf (2012). The soil type is a relic Gleysol (FAO-system) that developed in interaction with a formerly shallow water table. Since the 1960s, the water table was lowered by drinking water production and nowadays can be found in $3.8-4.5 \mathrm{~m}$ soil depth. The relatively low water capacity of the sandy soil is enhanced by a carbon rich former plaggic horizon that was shifted to a soil depth of $0.25-0.55 \mathrm{~m}$ by deep plowing before planting. The field was divided into four equally sized sectors that were cultivated with three different poplar hybrids. Two diagonally opposite sectors were cultivated with cuttings from "Max 1" (P. nigra $\times$ P. maximowiczii). On the other two sectors, "Androscoggin" (P. maximowiczii $\times$ P. trichocarpa) and "AF2" $(P$. deltoides $\times$ P. nigra $)$ were planted. No fertilizer or irrigation was applied. During the investigated growing season of 2011, the plants on average grew from 2.2 to $3 \mathrm{~m}$ mean stand height. Rooting depths was about $100 \mathrm{~cm}$. Leaf area index (LAI, i.e. leaf area per unit ground area) was measured several times during the growing season in the Max 1 and Androscogging sectors, using a light interception probe (type SS1, Delta-T Devices, Burwell, UK). LAl of the Max 1 canopy peaked in August at a value of $3.8 \mathrm{~m}^{2} \mathrm{~m}^{-2}$. Thistles (Cirsium palustre, L.) and tall grasses (Holcus lanatus, Secale cereale) were covering the ground between the tree rows, having a maximum LAI of 1.2 in June.

Our second study site (hereafter called "Großfahner") is located in the fertile keuper basin of Thuringia, near Erfurt in central Germany. There, we measured sap flux during the growing season 2012 using Granier-type thermal dissipation probes (TDP). The soil type is a eutric Cambisol (FAO-system) that developed from a thick loess cover. Roots can be found down to a soil depth of $250 \mathrm{~cm}$, where a groundwater table might buffer water shortage during periods of low precipitation. Since its establishment from cuttings in 2007 (clone "Japan J-105" - P. nigra $\times$ P. maximowiczii) to the investigated growing season of 2012, the stand had reached a height of about $9.5 \mathrm{~m}$ and the canopy was densely closed. Relative leaf area was estimated from hemispherical images to monitor foliation, senescence and leaf fall. Foliation was completed in the beginning of May; total leaf area was estimated from litterfall and specific leaf area, and amounted to a maximum LAI of $7.4 \mathrm{~m}^{2} \mathrm{~m}^{-2}$. LAI measured once during the mid-season with the same instrument used in Fuhrberg yielded a similarly high value of $7.9 \mathrm{~m}^{2} \mathrm{~m}^{-2}$. No understorey vegetation was present beneath the dense tree canopy; the ground was covered with leaf litter.

\subsection{Micrometeorological measurements and evaporative demand}

Meteorological variables were measured with sensors mounted on $10 \mathrm{~m}$ tall masts. In Fuhrberg, the mast was set up on the field, near the border between the "Max 1" and "Androscoggin" sectors. All measurements were made above the stand. In Großfahner, the mast was set up on a small strip between the poplar stand and a neighboring willow plantation. Basic data at both sites included incoming solar radiation $\left(R_{\mathrm{G}}\right)$, air temperature $\left(T_{\mathrm{A}}\right)$, relative humidity $(\mathrm{rH})$, wind speed $(u)$, wind direction and open-field precipitation $(P)$, spanning a period from April 15 to October 31 (doy 105-doy 305). All variables were measured every $5 \mathrm{~s}$, averaged at 10 -min intervals and aggregated to hourly and daily values for further analyses. Vapor pressure $(e)$ was derived from humidity and temperature measurements, following the conversion provided by Sonntag (1990). Equipment failure caused a data gap of three weeks in June at the Fuhrberg site. The gap was filled with hourly values from network stations run by the German Weather Service. Except for $P$, coming from a station at a distance of $4 \mathrm{~km}$ to the study site, all other variables came from a station at a distance of $16 \mathrm{~km}$ to the site with comparable meteorological conditions.

Total incoming and outgoing radiation was measured above the young Fuhrberg plantation using a newly calibrated pyrradiometer (type 8111, Schenk GmbH \& Co KG, Martinsried, Austria), from which net radiation $\left(R_{\mathrm{N}}\right)$ was calculated. In Großfahner, $R_{\mathrm{N}}$ was calculated from net shortwave radiation $\left(R_{\mathrm{NS}}\right)$ and net longwave radiation $\left(R_{\mathrm{NL}}\right)$. $R_{\mathrm{NS}}$ was estimated from incoming solar radiation $\left(R_{\mathrm{G}}\right)$ measured with a pyranometer (type CMP3, Kipp \& Zonen, Delft, The Netherlands), assuming an albedo of $25 \% . R_{\mathrm{NL}}$ was derived from incoming solar radiation, vapor pressure, air temperature and potential clear-sky solar radiation, following the instructions of Allen et al. (1998).

Volumetric soil water content was measured in Großfahner using three soil moisture sensors (SM-300, Delta-T Devices, Cambridge, UK), at 20, 60 and $120 \mathrm{~cm}$ soil depth respectively. To estimate total soil water content, the volumetric water contents were depth-interpolated and multiplied with the saturation water contents of the individual soil layers. In Fuhrberg, soil moisture was derived from soil water tension measured in 30,60 and $100 \mathrm{~cm}$ soil depth, using three tensiometers each in the upper two soil depths and ten tensiometers at $100 \mathrm{~cm}$ depth. Soil water tension was converted to volumetric water contents using the water release curves of the respective soil horizons, which we determined on undisturbed soil samples in the laboratory.

To relate vapor fluxes from the poplar plantations to actual climatic conditions, we calculated crop reference evapotranspiration $\left(\mathrm{ET}_{0}, \mathrm{~mm}\right)$ as the evapotranspiration from a hypothetical well-watered grass reference surface, using the Penman-Monteith combination equation (Monteith, 1965)

$\lambda \mathrm{ET}_{0}=\frac{s\left(R_{\mathrm{N}}-G\right)+\rho c_{\mathrm{p}} D g_{\mathrm{a}}}{s+\gamma\left(1+g_{\mathrm{a}} / g_{\mathrm{c}}\right)}$,

where $\lambda$ is the latent heat of vaporization of water $\left(\mathrm{Jg}^{-1}\right), s$ is the slope of the saturation vapor pressure versus temperature curve $\left(\mathrm{kPaK}^{-1}\right), \gamma$ is the psychrometric constant $\left(\mathrm{kPaK}^{-1}\right), \rho c_{\mathrm{p}}$ is the volumetric heat capacity of air $\left(\mathrm{J} \mathrm{m}^{-3} \mathrm{~K}^{-1}\right), G$ is ground heat flux $\left(\mathrm{J} \mathrm{m}^{2} \mathrm{~s}^{-1}\right)$, and $g_{\mathrm{c}}$ is canopy conductance for water vapor $\left(\mathrm{mm} \mathrm{s}^{-1}\right)$. The bulk aerodynamic conductance $\left(g_{\mathrm{a}}, \mathrm{m} \mathrm{s}^{-1}\right)$ was calculated from wind speed $\left(u, \mathrm{~m} \mathrm{~s}^{-1}\right)$, according to Businger (1956):

$g_{\mathrm{a}}=\frac{k^{2} u\left(z_{u}\right)}{\ln \left(z_{u}-d / z_{0}\right) \ln \left(z_{h}-d / z_{0}\right)}$,

where $z_{0}(\mathrm{~m})$ is roughness length for momentum and water vapor transfer and $d$ is zero plane displacement. The parameters $z_{\mathrm{u}}$ and $z_{\mathrm{h}}$ are sensor heights $(\mathrm{m})$ of wind speed and vapor pressure respectively, and $k$ is von Kármán's constant (dimensionless). The parameters $z_{0}$ and $d$ in Eq. (2) were estimated from the height ( $h=0.12 \mathrm{~m}$ ) of the theoretical grass reference surface as $d=0.66 \mathrm{~h}$ and $z_{0}=0.123 \mathrm{~h}, g_{c}$ for the grass reference surface was set to $14.3 \mathrm{~mm} \mathrm{~s}^{-1}$ (Allen et al., 1998). Ground heat flux was estimated as a portion of $R_{\mathrm{N}}$, being $10 \%$ of net radiation during daytime, and 50\% during nighttime (Allen et al., 1998).

\subsection{Evapotranspiration measurements}

\subsubsection{Choice of method}

In order to quantify evapotranspiration of the two poplar SRCs, two different methods had to be used, due to the differing canopy covers of the plantations. To monitor water use patterns of the young poplar plantation with its small trees and sparse canopy, the contribution of understorey transpiration and soil evaporation could not be ignored in water use estimations. For this reason, we chose the Bowen-ratio energy balance (BREB) method to estimate evapotranspiration, which accounts for vapor fluxes from all 
evaporating surfaces, including transpiration of poplar trees and understorey $\left(E_{\mathrm{t}}\right)$, evaporation of intercepted rainfall $\left(E_{\mathrm{i}}\right)$, and soil evaporation $\left(E_{\mathrm{s}}\right)$. At the mature plantation, whereas the poplar canopy was densely closed throughout the observation period and no ground vegetation was present, evapotranspiration could be assumed to originate only from canopy transpiration and evaporation of intercepted rainfall, while evaporation from the soil surface can be negligible (Kelliher et al., 1993). For this reason, the method of choice at Großfahner was the sap flux technique to quantify transpiration, combined with throughfall measurements to estimate interception evaporation. The latter was estimated on a daily basis as the difference between open-field precipitation and stand precipitation measured with a $4 \mathrm{~m}$ long raingutter $\left(0.65 \mathrm{~m}^{2}\right)$ and a tipping bucket.

\subsubsection{Bowen-ratio energy balance evapotranspiration}

measurements

The Bowen-ratio energy balance method (BREB) estimates the latent $(\lambda E)$ and sensible heat fluxes $(H)$ from the energy balance equation:

$R_{\mathrm{N}}=H+\lambda E+G$.

Eq. (4) can be rewritten in the form:

$\lambda E=\frac{R_{\mathrm{N}}-G}{1+\beta}$,

where $\beta$ is the Bowen-ratio $(H / \lambda E)$. The Bowen-ratio can be derived from vertical temperature $(\Delta T)$ and vapor pressure gradients $(\Delta e)$ in the constant flux layer above the stand. Assuming equal turbulent transfer coefficients for heat $\left(K_{\mathrm{H}}\right)$ and water vapor $\left(K_{\mathrm{E}}\right), \beta$ can be estimated by:

$\beta=\frac{H}{\lambda E}=\gamma \frac{K_{\mathrm{H}} \Delta T}{K_{\mathrm{E}} \Delta e}=\gamma \frac{\Delta T}{\Delta e}$.

In order to estimate temperature and vapor pressure gradients, the mast in Fuhrberg was equipped with three thoroughly calibrated combined $\mathrm{T} / \mathrm{rH}$ humidity probes (type HMP35D, Vaisala, Helsinki, Finland), mounted at two heights above the stand (two sensors at $6 \mathrm{~m}$ and one sensor approximately $0.3 \mathrm{~m}$ above the highest shoots) in ventilated radiation shields. The temperature sensor of this probe type is a platinum resistance thermometer (PT-100) in a four wire connection; relative humidity is measured by a capacitive sensor.

Ground heat flux $(G)$ was estimated from temporal change rates of the heat contents in $n=7$ soil layers:

$G=\sum_{i=1}^{n} \frac{\Delta T_{i}}{\Delta t_{i}} \rho_{i} c_{i}$

In this equation, $\rho_{\mathrm{i}} c_{\mathrm{i}}$ is the heat capacity of the $i$ th soil layer having a volume of unit area and layer thickness, and $\Delta T_{\mathrm{i}} / \Delta t$ is the temporal temperature change of that soil layer. Layer thicknesses increased with soil depth, the profile comprised an overall depth of $100 \mathrm{~cm}$. Layer temperatures were measured with soil temperature sensors (PT-100), the layer heat capacities were estimated by summing up the heat capacities of the layers' mineral and organic components, and water contents.

Estimations of latent heat fluxes obtained from Bowen-ratio measurements are usually afflicted with an error of $5-20 \%$, depending on actual micrometeorological conditions, sensor accuracy, and accuracy of the measured temperature and humidity gradients (Foken et al., 1997). In order to increase the overall accuracy of our temperature and humidity gradients, we increased the reliability of the sensor data by (1) interchanging and cross-calibrating the temperature/humidity probes, and (2) choosing the highest possible upper sensor height that the limited fetch conditions at Fuhrberg allowed.

For sensor cross-calibrations, one probe was constantly installed at $6 \mathrm{~m}$ height and served as a reference sensor. The other two sensors were interchanged once between the height of the reference sensor and the lower measuring height. Humidity readings of the two sensors were then corrected by first deriving new offsets and conversion factors from linear relationships between the readings of the reference sensor and the readings of the other two sensors for the period when installed next to the reference sensor. In a second step, we applied the new offsets and conversion factors to the sensor readings of the whole measuring period.

For maximizing the differences in temperature and humidity measurements between the two sensor heights and thus increase the accuracy of the overall gradients, we chose the highest possible upper sensor height for which the limited fetch conditions at the Fuhrberg site allowed. The mast position in the northern part of the rectangular field $(250 \times 160 \mathrm{~m})$ was approximately $70 \mathrm{~m}$ away from a forest at the north-eastern stand edge, and a willow SRC on the north-western stand edge. The south-eastern and south-western stand edges are bordered by narrow ecological compensation strips with grasses, scrubs and small trees. Beyond the south-western border strip there was a poplar SRC similar to the one studied, and beyond the south-eastern border strip there was cropland. The situation allowed for a fetch of $100-180 \mathrm{~m}$ for south-eastern to western wind directions, giving a fetch-to-heightratio of 25 to 45 at an upper sensor height of $6 \mathrm{~m}$. Under these conditions, fetch-induced errors could be assumed to be negligible (Heilman et al., 1989). Data gained downwind from the near forest edge (approximately $15 \%$ of the whole dataset) might be afflicted with higher errors, but were left in the final dataset to avoid longer data gaps when calculating total accumulated evapotranspiration.

Nevertheless, some of the 10 -minutes-records had to be excluded from the original dataset. Eq. (5) is not defined for $\beta=-1$, and latent heat fluxes calculated from Bowen-ratios close to this value are uncertain. For this reason, records with Bowen-ratios between -1.3 and -0.7 were discarded. Additionally, all data obtained during low wind speeds $\left(u<1 \mathrm{~m} \mathrm{~s}^{-1}\right)$ were discarded to ensure sufficiently turbulent measuring conditions. Data exclusion led to gaps occurring particularly during nighttime, and in dusk or dawn hours and accounted for $8 \%$ of the records. In order to calculate daily sums of evapotranspiration, these gaps were filled by linear interpolation, with a maximum interpolation interval of $2 \mathrm{~h}$ during daytime, and $5 \mathrm{~h}$ during nighttime. Longer gaps caused by equipment failure or maintenance works were filled by assuming evapotranspiration to be $80 \%$ of crop reference evaporation $\left(\mathrm{ET}_{0}\right)$, which was the average crop coefficient $\left(E / E_{0}\right)$ observed during the main growing season. Unlike for quantifying daily evapotranspiration, only complete hourly datasets were used for computing canopy conductance.

To get an error estimate of the latent heat fluxes, and evaluate the efficiency of the above described measures, we used a MonteCarlo uncertainty estimation technique similar to the one described in Elsawwaf et al. (2010). The technique reflected measurement uncertainties from limited sensor accuracy, by random uniform variation of the raw sensor data. To temperature and humidity sensor readings at the two measuring heights, we added uncertainties in a range of $\pm 0.1 \mathrm{~K}$ and $\pm 1.5 \%$, respectively. The energy balance components $R_{\mathrm{N}}$ and $G$ received relative uncertainties of $\pm 10 \%\left(R_{\mathrm{N}}\right)$ and $\pm 20 \%(G)$. A large number of random samples (i.e. $n=500$ ) was drawn from the uniform uncertainty intervals, and latent heat flux was recalculated for each sample. In a last step, hourly means and standard errors were estimated across all 500 heat flux time series. 


\subsubsection{TDP sensor calibration and sap flux-scaled stand} transpiration measurements

At the Großfahner site, xylem sap flux densities $\left(F_{\mathrm{d}}, \mathrm{m}^{3} \mathrm{~m}^{-2} \mathrm{~s}^{-1}\right)$ of individual trees were measured using Granier-type thermal dissipation probes (TDP) manufactured according to the original design given by Granier (1985), and scaled to stand transpiration. However, to account for small tree diameters at breast height (DBH) ranging from 4 to $9 \mathrm{~cm}$ and to avoid contact of the sensor with non-conductive heartwood, pairs of $10 \mathrm{~mm}$-long and $2 \mathrm{~mm}$ wide heating probes were chosen, which deviates in length and resistance of the heating wire from Granier's original $20 \mathrm{~mm}$-long sensor. The upper probe was constantly heated with $120 \mathrm{~mA}$, resulting in a constant power of $0.1 \mathrm{~W}$ for the $7 \Omega$ heater resistance, which is half of the power provided to $20 \mathrm{~mm}$-long Granier type sensors. The temperature difference $(\Delta T)$ between the two sensors was recorded with copper-constantan (Cu-Co) thermocouples placed at the center of the heating coil. The lower probe was not heated and served as reference for the upper probe. The distance between the two sensor probes was kept at about $10 \mathrm{~cm}$ to avoid thermal interference. From $\Delta T$ and $\Delta T_{\max }$ ( $\Delta T$ at zero flow) sap flux density can be calculated. Although others studies (e.g. James et al., 2002) have used $10 \mathrm{~mm}$-long TDP sensors, these authors adjusted the power input to the modified sensor such as $\Delta T_{\max }$ remained similar to that of the original-type probes (Lu et al., 2004). However, this was not possible with our power supply setup and required a new empirical laboratory TDP sensor calibration.

For the calibration, five tree individuals growing at the Großfahner site were felled in autumn 2013 and stem segments with an average length of $200 \mathrm{~cm}$ were immediately wrapped with wet towels, stored in dark plastic bags and transported to the laboratory. The fresh segments (mean diameter \pm SE: $10.30 \pm 0.48 \mathrm{~cm}$ ) were re-cut to $100 \mathrm{~cm}$ length with a high precision circular saw, and attached to a tubing system in flow direction, while the basipetal end was submersed in a container filled with distilled, filtered $(0.22 \mu \mathrm{m})$ and degased water $\left(10 \mathrm{mM} \mathrm{KCl}\right.$ and $\left.1 \mathrm{mM} \mathrm{CaCO}_{3}\right)$. Ten different vacuum pressure steps from 5 to $50 \mathrm{kPa}$ were applied in order to simulate a natural range of flow conditions for each segment attached, and the flow rate was gravimetrically measured with a laboratory scale at $0.5 \mathrm{~g}$ resolution (Kern DE35K0.5D, Kern \& Sohn GmbH, Balingen, Germany). Per stem, two $10 \mathrm{~mm}$-long TDP sensors were installed in opposite direction. All data (pressure, weight and $\Delta T$ ) were averaged every minute from $10 \mathrm{~s}$ measurements and recorded with a data logger (CR1000, Campbell Scientific Inc., Logan, UT, USA). The measurements for each pressure step lasted for $75 \mathrm{~min}$, the first and last $15 \mathrm{~min}$ were dismissed, and the remaining 45 values averaged per pressure step. All averaged values per TDP sensor were used for a non-linear regression analysis according to Granier (1985) as:

$F_{\mathrm{d}}=a \times 10^{-6}\left[\frac{\left(\Delta T_{\max }-\Delta T\right)}{\Delta T}\right]^{b}$,

where $F_{\mathrm{d}}$ is the sap flux density $\left(\mathrm{m}^{3} \mathrm{~m}^{-2} \mathrm{~s}^{-1}\right),\left(\Delta T_{\max }-\Delta T\right) / \Delta T$ is the dimensionless flow index named $K$, and $a$ and $b$ are the coefficients depending on the quantity of heat applied. We found different calibration factors as described by Granier's original equation $(a=118.99 ; b=1.231)$, which would have underestimated real flow especially at high flow rates (Fig. 1). As suggested by Granier (1985), changes in the field around the probe, i.e. the sensor length, may cause deviation in the calibration factors (Lu et al., 2004). According to our laboratory TDP calibration, sap flux density measured with $10 \mathrm{~mm}$-long sensors in Poplar can be calculated as:

$F_{\mathrm{d}}=352.01 \times 10^{-6}\left[\frac{\left(\Delta T_{\max }-\Delta T\right)}{\Delta T}\right]^{1.552}$

The same five fresh segments were used for sapwood area determination in the laboratory. A dye solution $(0.1 \%$ Safranin 0 ,

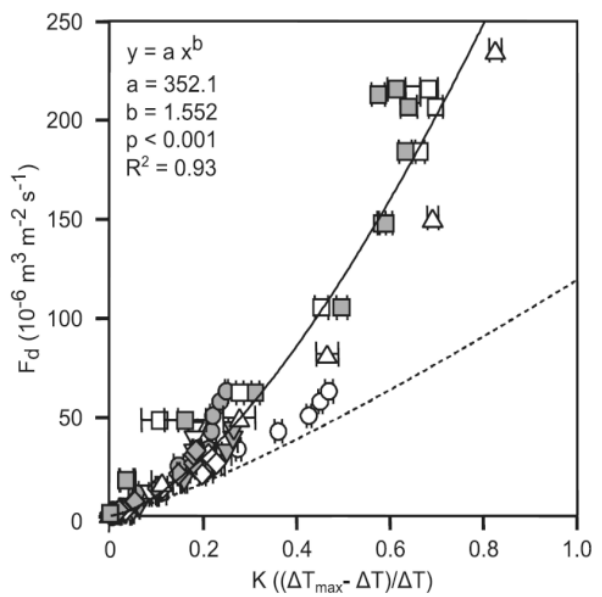

Fig. 1. Non-linear regression analysis on the relation between sap flux density $\left(F_{\mathrm{d}}\right.$, $\left.\mathrm{m}^{3} \mathrm{~m}^{-2} \mathrm{~s}^{-1}\right)$ and the dimensionless sap flux index $K$. Given values are means $\pm \mathrm{SE}$ per pressure step and sensor. In total five stems (P1 to P5) equipped with two TDP sensors each (S1 or $\mathrm{S} 2$ ) were measured. The dashed line represents $F_{\mathrm{d}}$ calculated from $K$-values according to Granier's calibration factors $(a=118.99 ; b=1.231)$. The different markers represent the different sensors per stem used ( $O$ P1_S1; O P1_S2; $\nabla$ P2_S1; $\nabla$ P2_S2; $\diamond$ P3_S1; $\diamond$ P3_S2; $\Delta$ P4_S2; $\square$ P5_S1; $\square$ P5_S2).

Merck, Darmstadt, Germany) was pulled through the segments and approximately $2 \mathrm{~cm}$ discs cut out at $20 \mathrm{~cm}$ distance from the basipetal end with a high precision circular saw. The discs were scanned (Epson Expression 1680, Seiko Epson Corp., Nagano, Japan) and cross-sectional area and corresponding sapwood area analyzed with the software ImageJ (v1.47, http://rsb.info.nih.gov/ij). According to a linear regression analysis, sapwood area of each individual can be calculated as $A_{\text {sapwood }}\left(\mathrm{cm}^{2}\right)=9.823+0.707 A_{\text {cross }}\left(\mathrm{cm}^{2}\right)(n=5$, $p<0.001, R^{2}=0.99$ ). The confidence limits of the regression parameters suggest the estimation error for $A_{\text {sapwood }}$ to be $10 \%$. On average, $93.5 \pm 1.2 \%$ (mean $\pm \mathrm{SE}$ ) of the corresponding cross-section including pith and bark was conductive sapwood.

In the field, sensors were installed at breast height on $n=7$ trees covering the whole DBH range present in the stand. To reduce errors from stem run-off and insolation, all sensors were protected. To additionally account for errors from thermal gradients due to insolation occurring especially during morning hours, we used a cyclic measurement (Lu et al., 2004): 15 min measurement without heating, $10 \mathrm{~min}$ pre-heating (without measuring) and $15 \mathrm{~min}$ measurement with heating. Measurements were done every $10 \mathrm{~s}$, averaged over the $15 \mathrm{~min}$ period and assigned as hourly value. To correct the heated temperature difference for natural thermal gradients we used the non-heated values. In the application of Granier's method the determination of $\Delta T_{\max }$ is essential for calculating $F_{\mathrm{d}}$. Lu et al. (2004) already discussed certain factors that may prevent the occurrence of a zero flow state (defined for $\left.\Delta T=\Delta T_{\max }\right)$. Particularly the night-time water movement for new vegetative or reproductive growth seems to be important for fast growing species like poplar. Therefore $\Delta T_{\max }$ was estimated from the corrected values over a 10-day period, following the doubleregression method described in Lu et al. (2004). To avoid individual extreme $\Delta T$ values affecting the calculation of $F_{\mathrm{d}}$, spiking maxima were excluded before estimating the $\Delta T_{\max }$ for every tree separately.

To calculate hourly stand transpiration rates, $F_{\mathrm{d}}$ measurements of five trees were averaged. Two trees showed very low sap flux densities probably due to insufficient contact between probe and surrounding wood and were excluded from further analyses. In general, transpiration rates are calculated from sap flux densities times the sapwood area. Sap wood areas are calculated after 
applying the linear regression described above to all DBH-classes . $(1 \mathrm{~cm}$ classes, ranging from 1 to $12 \mathrm{~cm})$, considering the DBH distribution of the stand and the total number of trees per hectare $\left(9454 \mathrm{ha}^{-1}\right)$. The sapwood area of the stand is derived by integrating the sap wood areas of all DBH-classes. The stand transpiration rate was calculated as the product of average hourly sap flux densities and the integrated sapwood area of the stand, considering the DBH distribution of the stand and the number of trees per hectare.

\subsection{Canopy conductance estimations}

Canopy conductance $\left(g_{c}\right)$ of plant stands that are well coupled to the atmosphere is closely linked to the stomata conductances of the leaves constituting the canopies (Jarvis and McNaughton, 1986). Stomata respond to environmental variables like evaporative demand, photosynthetic active radiation, air temperature and soil water availability. In order to compare canopy conductances of the two study sites, we therefore defined meteorological reference conditions (Granier et al., 2000b), corresponding to standardized situations where the air was moderately dry $(D=1 \pm 0.3 \mathrm{kPa})$, radiation not limiting transpiration $\left(R_{\mathrm{G}} \geq 400 \mathrm{~W} \mathrm{~m}^{-2}\right.$, visually derived from plotting $E_{\mathrm{t}}$ vs. $R_{\mathrm{G}}$ ), the canopy was dry ( $P=0$ during past $10 \mathrm{~h}$ ), and ventilated $\left(u \geq 1 \mathrm{~m} \mathrm{~s}^{-1}\right)$ to warrant sufficient coupling between canopy and atmosphere. Canopy conductance under reference conditions $\left(g_{\mathrm{c}}^{*}\right)$ can be interpreted like estimates of maximum canopy conductances (Körner, 1994). However, maximum conductance is difficult to identify and measure in the field (Arneth et al., 1996; Martin et al., 1997), $g_{c}^{*}$ is a more straightforward way to characterize the water use potential of a plant stand.

Hourly $g_{c}$ values were calculated from transpiration rates and meteorological variables by inverting the Penman-Monteith equation (Eq. (1)):

$g_{c}=\frac{\lambda E_{t} \gamma g_{\mathrm{a}}}{s\left(R_{\mathrm{N}}-G\right)+\rho c_{\mathrm{p}} D g_{\mathrm{a}}-\lambda E_{\mathrm{t}}(s+\gamma)}$.

Different from the sap flux technique that offered a direct estimation of transpiration at the Großfahner site, BREB vapor flux measurements at Fuhrberg beyond transpiration also included vapor fluxes from wet plant surfaces, and from the soil surface. Conductance estimations from evapotranspiration rates thus rather have to be classified as ecosystem surface conductance measurements (Kelliher et al., 1993). However, to keep values from Fuhrberg comparable to the transpiration-derived $g_{\mathrm{c}}$ estimations from Großfahner, we eliminated interferences from interception and soil evaporation that caused large temporal variations in $g_{c}$ values at Fuhrberg. Interception evaporation was already removed by filtering $g_{c}$ values for meteorological reference conditions. Apart from that, we filtered the $g_{c}$-dataset for wind directions with favorable fetch conditions and excluded morning records containing evidence for dew evaporation. Soil evaporation was not excluded completely from the measurements, as it can make up for notable portions of in the water balance of ecosystems with open canopies (Kelliher et al., 1993) like the young Fuhrberg poplar plantation. However, evapotranspiration and $g_{c}$ was heavily increased for approximately one or two days after heavy rainstorms, probably due to increased soil evaporation. In order to keep the measurements comparable, we excluded these records from the $g_{c}$ analyzes. Nevertheless, soil evaporation was kept as normal background noise in the remaining dataset, because it has to be considered when comparing water use of open and closed canopies.

\subsection{Water use strategies}

The water use strategies of the plant stands (isohydric or anisohydric) were inferred from the relative reduction of observed $g_{c}$ in response to increasing $D$ (i.e. the stomatal sensitivity) on a monthly basis. The response was compared to theoretical stomatal sensitivities for isohydric behavior, provided by the framework described in Oren et al. (1999).

To analyze the stomatal response to vapor pressure deficit, the hourly $g_{c}$-dataset acquired under meteorological reference conditions (see above) was used, without the restriction on $D$. We split the dataset into monthly subsets (May-October), and plotted canopy conductance against $D$ for each month. The monthly data clouds were classified into vapor pressure deficit intervals of $0.2 \mathrm{kPa}$, starting at $0.9 \mathrm{kPa}$. For all $D$-classes, mean canopy conductance plus standard deviation was calculated to construct the upper envelopes of the monthly data-subsets. These upper envelopes represented the highest possible $g_{c}$-values at any given saturation deficit, where no other environmental factors were supposed to limit canopy conductance of the poplar stands. The following response function (Oren et al., 1999) was fitted to the upper envelopes:

$g_{c}=g_{\text {cref }}-m \ln D$.

In Eq. (10), $g_{\text {cref }}$ is the reference canopy conductance $\left(g_{c} @ 1 \mathrm{kPa}\right)$ and $m$ is the sensitivity of the $g_{c}$ response to $D\left(\mathrm{~mm} \mathrm{~s}^{-1} \mathrm{kPa}^{-1}\right)$. Their ratio $\mathrm{m} / \mathrm{g}_{\text {cref }}$ indicates whether the leaves of the investigated plants show isohydric behavior or not, when compared to a theoretical ratio derived by a simple hydraulic model. In case of isohydric behavior, the stomata response to increasing $D$ is sufficient to keep the difference between soil and leaf water potential $\left(\Psi_{\text {S-L }}, \mathrm{kPa}\right)$ constant. In this case, theoretical considerations show that the total ecosystem-atmosphere conductance $g_{\text {su }}\left(g_{\mathrm{a}}\right.$ and $g_{\mathrm{c}}$ in series: $\left.g_{\mathrm{su}}=\left(g_{\mathrm{a}}{ }^{-1}+g_{c}{ }^{-1}\right)^{-1}\right)$ is inversely proportional to $D$ (Oren et al., 1999):

$g_{\text {su }}=\frac{k}{A_{\mathrm{L}}} \frac{1}{D} \Psi_{\mathrm{S}-\mathrm{L}}$,

where $k / A_{\mathrm{L}}$ is the hydraulic conductance of the soil-to-leaf pathway $\left(\mathrm{m} \mathrm{s}^{-1}\right)$. Eq. (11) can thus be used to model isohydric behavior, by keeping $\Psi_{\text {S-L }}$ constant and predict an isohydric $g_{\text {su }}$ (and, if $g_{\mathrm{a}}$ is known, also isohydric $g_{c}$ ) for a range of $D$ values. Eq. (10) can then be fitted to the modeled isohydric data and the corresponding theoretical $\mathrm{m} / \mathrm{g}_{\text {cref }}$ ratio can be compared to the fitted parameters from field observations. If the ratios are identical, it can be concluded that the investigated poplar plantation displays an isohydric behavior. In contrast, an observed ratio lower than the theoretical one indicates that the plants keep their stomata more widely open under atmospheric drought, tolerating a drop in leaf water potential to keep up their ability to assimilate carbon.

Across a large number of tree species and environmental conditions, the sensitivity of $g_{\mathrm{c}}$ to $D(m)$ was found to be remarkably constant, equaling roughly a universal relationship of $m=0.6 g_{\text {cref }}$ (Ewers et al., 2005; Naithani et al., 2012; Oren et al., 1999; Pataki and Oren, 2003). This proportionality is consistent with the theoretical $\mathrm{m} / \mathrm{g}_{\text {cref }}$ ratio from the hydraulic model described by Eq. (11), and facilitates comparisons of canopy conductance between plant stands and seasons. However, the theoretical $\mathrm{m} / \mathrm{g}_{\text {cref }}$ ratio can vary considerably with the applied range of $D$ (because Eq. (10) describes a logarithmic response of $g_{c}$ to $D$ whereas the theoretical response in equation (11) is hyperbolic) and the $g_{a} / g_{c}$ ratio. This potentially masks anisohydric behavior inferred from comparisons of observed $\mathrm{m} / \mathrm{g}_{\text {cref }}$ ratios to the universal theoretical ratio of 0.6 that actually can be higher in cool and humid climates (Herbst et al., 2008). We thus modeled the theoretical $\mathrm{m} / \mathrm{g}_{\text {cref }}$ ratios for each of the monthly data-subsets, using the actually observed range of $D$ (lower limit: $1 \mathrm{kPa}$ ) and the mean boundary layer conductance to detect differences between observed stomatal responses and theoretical isohydric responses. 


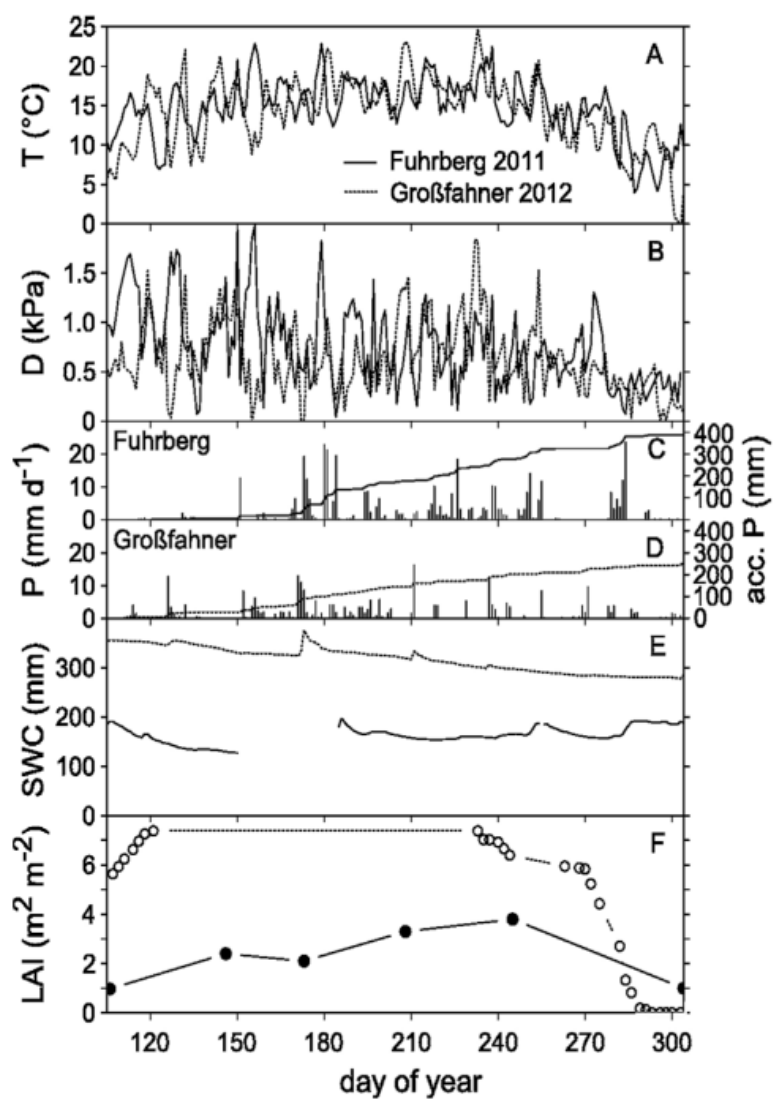

Fig. 2. (A) Mean daily air temperature ( $T$ ), (B) mean daytime vapor pressure deficit $(D),(C, D)$ daily (bars) and accumulated (lines) precipitation $(P),(E)$ soil water content (SWC; at 0-1 m) and (F) leaf area index (LAI) at Fuhrberg (solid lines, April 15-Oct 31,2011 ), and Großfahner (dashed lines, April 15-Oct 31,2012) poplar plantations.

\section{Results}

\subsection{Microclimate and leaf area development}

Fig. 2 shows microclimate and canopy development during the growing seasons, as measured in Fuhrberg (2011) and Großfahner (2012). Spring 2011 was dry and warm in Fuhrberg (Fig. 2A and $B$ ), though a late frost period with minimum temperatures of $-4.8^{\circ} \mathrm{C}$ occurred in the beginning of May during days of year (doy) $122-126$, damaging the leaves of the poplar trees. The leaves recovered until the end May, but leaf area index (LAI, Fig. 2F) in June was again affected by herbivorous red poplar leaf beetles (Chrysomela populi). Due to the damage and the ongoing height growth, the young poplars reached their maximum $\operatorname{LAI}\left(3.8 \mathrm{~m}^{2} \mathrm{~m}^{-2}\right)$ relatively late in the season (July-August). During spring and early summer only little rain fell, and soil water storage (SWC; $0-1 \mathrm{~m}$ soil depth) dropped from about $190 \mathrm{~mm}$ to below $130 \mathrm{~mm}$ in Fuhrberg (Fig. 2E), corresponding to $60 \%$ of maximum extractable soil water (soil water storage between pF 1.8 and pF 4.2). SWC recovered during two weeks in June and July (doy 170-185) when dry and warm weather was interrupted several times by larger storms that brought $115 \mathrm{~mm}$ of rain (Fig. 2C). In August, atmospheric conditions stayed relatively humid until a dry period from mid-September (doy 256) to the beginning of October, which ended with ample amounts of precipitation $(57 \mathrm{~mm})$ falling around doy 280 . This amount was sufficient to refill the soil water storage to the $190 \mathrm{~mm}$ level, where it remained until the end of the observation period.

In Großfahner, precipitation during the observation period $(P$, $256 \mathrm{~mm}$, Table 1) was only two thirds of the amount measured in
Fuhrberg $(387 \mathrm{~mm})$. Half of this amount fell during June and July. In general, the first half of the season was more humid compared to Fuhrberg, the second half was drier. On average, SWC was higher than in Fuhrberg, due to the different soil physical properties (silt loam vs. sand), and decreased constantly from doy 120 (356 mm) until the end of the observation period $(288 \mathrm{~mm})$. The groundwater level fell from 220 to $270 \mathrm{~cm}$ soil depth. Extractable soil water did not fall below $60 \%$ of the maximum value $(205 \mathrm{~mm})$. At the beginning of the observation period, LAI was already above $5 \mathrm{~m}^{2} \mathrm{~m}^{-2}$, and foliation was completed in the beginning of May. Maximum LAI $\left(7.4 \mathrm{~m}^{2} \mathrm{~m}^{-2}\right)$ was almost twice as high as in Fuhrberg.

\subsection{Evapotranspiration and water balance}

Fig. 3 shows the seasonal courses of daily evapotranspiration ( $E$, bars) and the 5-day moving average crop reference evaporation $\left(\mathrm{ET}_{0}\right)$ at the young (Fig. 3A) and full-grown (Fig. 3B) poplar plantations Fuhrberg and Großfahner, respectively. For reasons of comparability, grey bars for Fuhrberg indicate vapor flux measured by the BREB method on days with rainfall $(P>0.2 \mathrm{~mm})$, thus these evapotranspiration values potentially contain evaporation of intercepted rainfall, which was not measured separately at that site. Black bars show $E$ values on days with negligible rainfall and interception, thus these values mostly consist of transpiration $\left(E_{\mathrm{t}}\right)$ and soil evaporation $\left(E_{\mathrm{s}}\right)$. For Großfahner, black bars show sap flux-derived stand transpiration $\left(E_{\mathrm{t}}\right)$, stacked grey bars indicate the share of interception evaporation $\left(E_{i}\right)$ in daily $E$. At both sites, maximum evapotranspiration was $4-5 \mathrm{~mm} \mathrm{~d}^{-1}$ with occasionally occurring higher values. In the first half of the growing season, $\mathrm{ET}_{0}$ in general was higher at the Fuhrberg site due to longer warm and rainless periods than at $\mathrm{Gro}$ fahner, where $\mathrm{ET}_{0}$ in turn was higher in the second half of the observation period. Due to equipment failure, there was a 20-day long data gap at Fuhrberg in June, coinciding with warm and dry weather and high evaporative demand.

At Großfahner, daily stand transpiration showed a seasonal trend with very low $E_{\mathrm{t}}$ of $0.2 \mathrm{mmd}^{-1}$ at the beginning of the observation period (mid-April, doy 105-110), when leaves were expanding (Fig. 2F). Within a week (doy 115-121), $E_{\mathrm{t}}$ rapidly increased to values around $2.5 \mathrm{~mm} \mathrm{~d}^{-1}$. An initial discrepancy between $E_{\mathrm{t}}$ and $\mathrm{ET}_{0}$ became small, $E_{\mathrm{t}}$ subsequently varied closely with $\mathrm{ET}_{0}$. Highest transpiration rates were measured on rainless days from mid-May until mid-August (doy 130-230), when $\mathrm{ET}_{0}$ was high and $E_{\mathrm{t}}$ regularly exceeded $4 \mathrm{~mm} \mathrm{~d}^{-1}$ (max. $\left.E_{\mathrm{t}}: 4.5 \mathrm{~mm} \mathrm{~d}^{-1}\right)$. Average $E_{\mathrm{t}}$ during the main growing season (May-September) was $2.35 \pm 1.12 \mathrm{~mm} \mathrm{~d}^{-1}$ (mean \pm standard deviation) and $3.16 \pm 0.81 \mathrm{mmd}^{-1}$ on rainless days. On days with rainfall, interception evaporation caused total evapotranspiration to exceed $\mathrm{ET}_{0}$ considerably. From September, $E_{\mathrm{t}}$ decreased gradually with leaf fall to zero at doy 295 .

At Fuhrberg, mid-season mean evapotranspiration on rainless days (excluding interception evaporation) was $2.34 \pm 0.13 \mathrm{~mm} \mathrm{~d}^{-1}$. A seasonal trend was hardly distinguishable, due to comparably high evapotranspiration $\left(>2.5 \mathrm{~mm} \mathrm{~d}^{-1}\right)$ from the beginning of the observation period. The highest evapotranspiration rates were observed during the first half of the growing season, when $\mathrm{ET}_{0}$ was high. Unlike at Großfahner, $E$ values that considerably exceeded $\mathrm{ET}_{0}$ were not necessarily caused by the contribution of interception evaporation, as they occurred also on rainless days with high evaporative demand. They occurred shortly after heavy rainstorms, especially at the end of June (doy 180) and mid-July, and might have been caused by a significant contribution of evaporation from the wet soil to evapotranspiration. From August, $E$ and $\mathrm{ET}_{0}$ did not reach the previous high values anymore, and during a rainless period around doy $270, E$ was already considerably lower than $\mathrm{ET}_{0}$.

Total evapotranspiration from the young and full-grown poplar coppices amounted to $380 \mathrm{~mm}$ and $445 \mathrm{~mm}$, respectively (Table 2). 

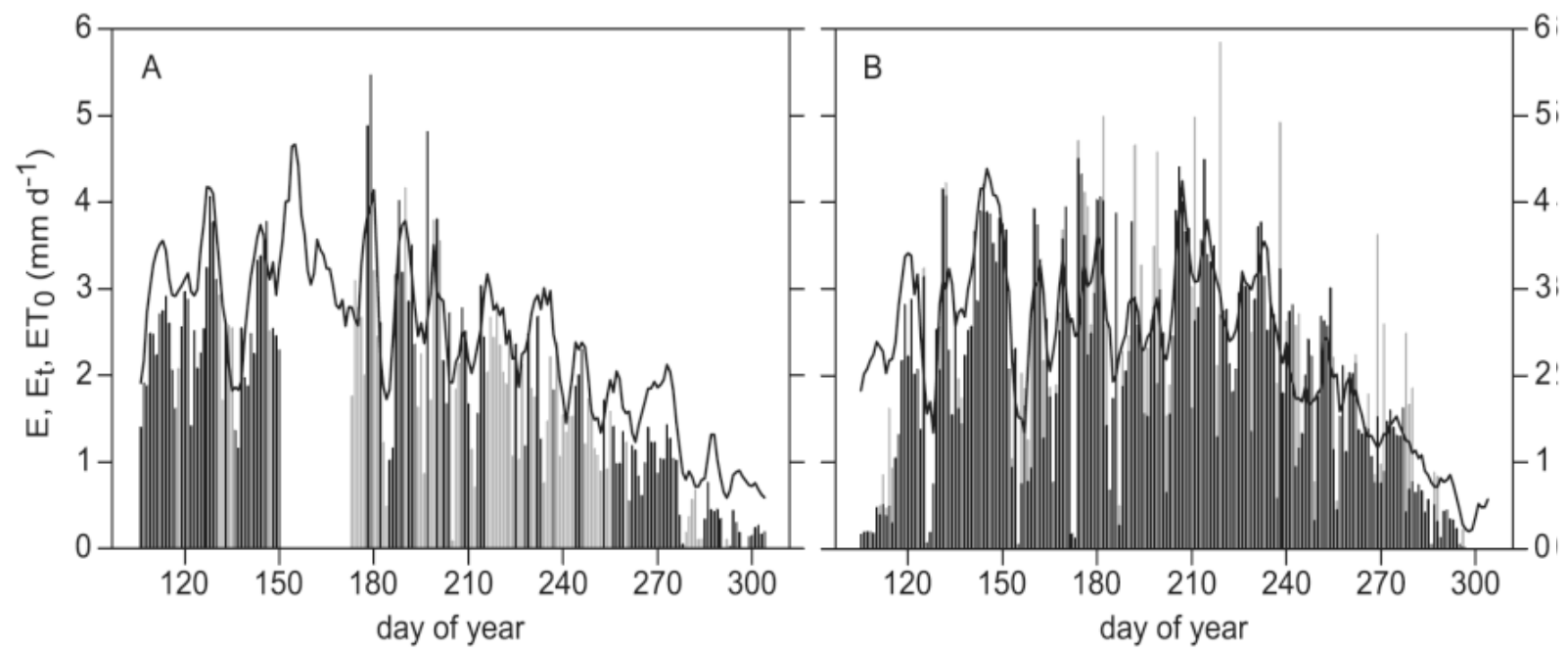

Fig. 3. Daily sums of measured evapotranspiration ( $E$, bars) and crop reference evaporation ( $\mathrm{ET}_{0}$, lines, 5-day moving average) at the young (A) and mature (B) poplar" plantations. Evapotranspiration ( $E$ ) at Großfahner was calculated as the sum of stand transpiration ( $E_{\mathrm{b}}$, black bars) and interception evaporation ( $E_{i}$, stacked grey bars). For Fuhrberg, grey bars show $E$ on days with $P>0.2 \mathrm{~mm}$, potentially containing interception evaporation. Black bars show $E$ on days with negligible rainfall and interception.

At Großfahner, interception evaporation was $23 \%$ of total $P$ (58 mm). Mean crop coefficients, calculated from total $E / \mathrm{ET}_{0}$ (Allen et al., 1998) were 0.78 at Fuhrberg, and 0.96 at Großfahner. In Fuhrberg, the error in the growing season water balance was small, whereas total transpiration $E_{\mathrm{t}}(387 \mathrm{~mm})$ at Großfahner was higher than the sum of net stand precipitation and measured $\triangle \mathrm{SWC}$, indicating root water uptake from the deep soil below $120 \mathrm{~cm}$ depth or the groundwater table.

Fig. 4 shows the seasonal courses of the crop coefficient $\left(E / \mathrm{ET}_{0}\right)$ at the two study sites. Data are shown only for days with negligible rainfall and interception evaporation, in order to exclude values afflicted with interception evaporation at Fuhrberg, and to guarantee a dry, freely transpiring tree canopy at Großfahner. The day-to-day variability of the crop coefficient is lower than the variability of evapotranspiration rates, as it relates evapotranspiration to evaporative demand. Moreover, it shows how measured $E_{\mathrm{t}}$ at Großfahner, and the sum of transpiration and soil evaporation $\left(E_{\mathrm{t}}+E_{\mathrm{s}}\right)$ at Fuhrberg differ from potential evapotranspiration of a well-watered grass surface (dashed line). Hence, the seasonal trend observed in transpiration rates from the mature SRC (Fig. 3B) is more pronounced in Fig. 4, and a weak seasonal trend emerges as well for the young SRC. There, $E / \mathrm{ET}_{0}$ seemed to slightly increase from values around 0.7 in April to maximum values between 0.9 and 1.0 in June and July (doy 150-210). On several occasions, E/ET was well above 1.0, corresponding to the mentioned days after heavy rainfall when the soil was wet and $E_{\mathrm{s}}$ might have contributed

Table 2

Accumulated water balance components from April 15 and October 31 at Fuhrberg (year 2011) and Großfahner (year 2012).

\begin{tabular}{lll}
\hline -all in mm- & Fuhrberg & Großfahner \\
\hline Reference evaporation $\left(\mathrm{ET}_{0}\right)$ & 481 & 465 \\
Precipitation $(P)$ & 387 & 256 \\
Transpiration $\left(E_{\mathrm{t}}\right)$ & $\mathrm{n} . \mathrm{m}$. & 387 \\
Interception evap. $\left(E_{\mathrm{i}}\right)$ & $\mathrm{n} . \mathrm{m}$. & 58 \\
Soil evaporation $\left(E_{\mathrm{s}}\right)$ & $\mathrm{n} . \mathrm{m}$. & $\mathrm{n} . \mathrm{m}$. \\
Evapotranspiration $(E)$ & 380 & $445^{\mathrm{a}}$ \\
Soil water content change $(\Delta \mathrm{SWC})^{b}$ & 3 & -96 \\
Water balance $(\mathrm{WB})^{\mathrm{c}}$ & +4 & -93 \\
\hline
\end{tabular}

a Calculated as $E=E_{\mathrm{t}}+E_{\mathrm{i}}$.

b Integrated soil depths: $100 \mathrm{~cm}$ (Fuhrberg), $120 \mathrm{~cm}$ (Großfahner).

c Calculated as WB $=P-E-\Delta S W C$. considerably to $E$. The day-to-day variability during this period is; high, and seems to slightly decrease from August. At the mature: SRC, crop coefficients of 0.94 on average (doy 130-280) were sus-. tained on rainless days throughout the main growing season untill the beginning of October that regularly exceeded crop reference: evapotranspiration.

\subsection{Canopy conductance and water use strategy}

Fig. 5 shows daily means ( \pm 1 standard deviation) of hourly canopy conductance at the study sites, measured under meteorological reference conditions $\left(g_{c}^{*} \mid R_{G} \geq 400 \mathrm{Wm}^{-2}\right.$, $D=1 \pm 0.3 \mathrm{kPa}, u \geq 1 \mathrm{~m} \mathrm{~s}^{-1}, P=0 \mathrm{~mm}$ during past $10 \mathrm{~h}$ ). For comparability reasons, measurements after heavy rainfall that led to very high crop coefficients at Fuhrberg (Fig. 4A) were additionally' excluded, as they caused very high conductances comparable to values measured during interception evaporation at the young; plantation. Compared to the seasonal courses of $E / \mathrm{ET}_{0}$ (Fig. 4) at: the studied poplar coppices, some similarities can be observed, but: at the same time some additional intricacies emerge. In agreement: to the crop coefficient, highest $g_{c}^{*}$ were observed during the main। growing season at both sites, but $g_{c}^{*}$ in general appeared more vari-. able than $E / E_{0}$. This variation reflects influencing factors like low' air temperatures (Fig. 1A) causing a depression in mid-May (doy' 135) at Großfahner (Fig. 5B), and beginning leaf senescence and litter fall from the end of August that might have led to decreasing; canopy conductance of the mature plantation in September.. However, the most important difference between $g_{c}^{*}$ and crop coefficients is in higher maximum $g_{\mathrm{c}}^{*}$ at the mature plantation (ca.. $12-18 \mathrm{~mm} \mathrm{~s}^{-1}$ vs. $8-12 \mathrm{~mm} \mathrm{~s}^{-1}$ at the young plantation), while the: differences between $E / \mathrm{ET}_{0}$ were small. At the young plantation,, the weak seasonal trend surmised from crop coefficients became: more distinct when regarding $g_{c}^{*}$, as an increase of values could be observed between mid-April (doy 105) and end of May (doy' 150 ). In the early-season, $g_{c}^{*}$ at Fuhrberg was on a base level of $5 \mathrm{~mm} \mathrm{~s}^{-1}$, and increased during May to reach maximum values.. In the beginning of August (doy 210), $g_{c}^{*}$ again decreased to $7-8 \mathrm{~mm} \mathrm{~s}^{-1}$, where it remained before decreasing gradually from । early September (doy 255) to beginning of October (doy 280). From। mid-October, ambient $D$ did not reach the range of meteorologicall reference conditions anymore, thus no $g_{c}^{*}$ values are shown. 

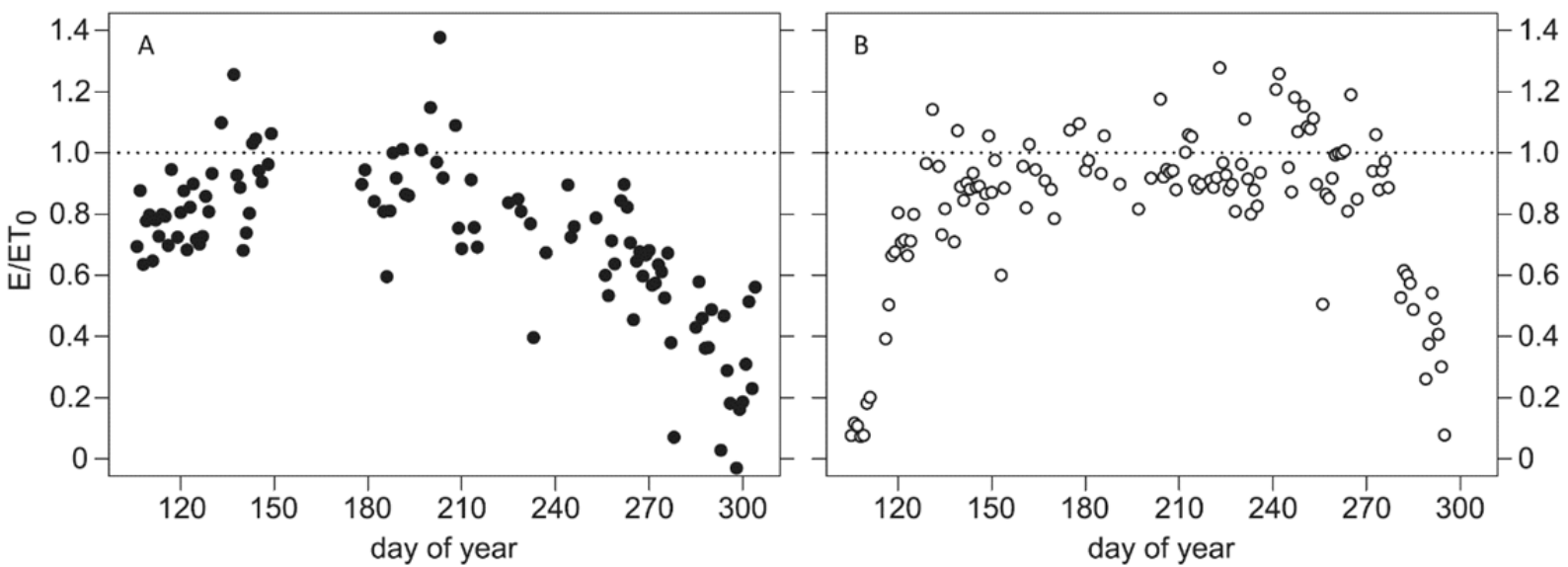

Fig. 4. Seasonal course of the crop coefficient (daily evapotranspiration $E$ divided by crop reference evaporation (ET $)$ at Fuhrberg $(\mathrm{A})$ and $\mathrm{Gro}$ fahner (B). Only data for days with negligible rainfall $(P \leq 0.2 \mathrm{~mm})$ and interception evaporation are shown.
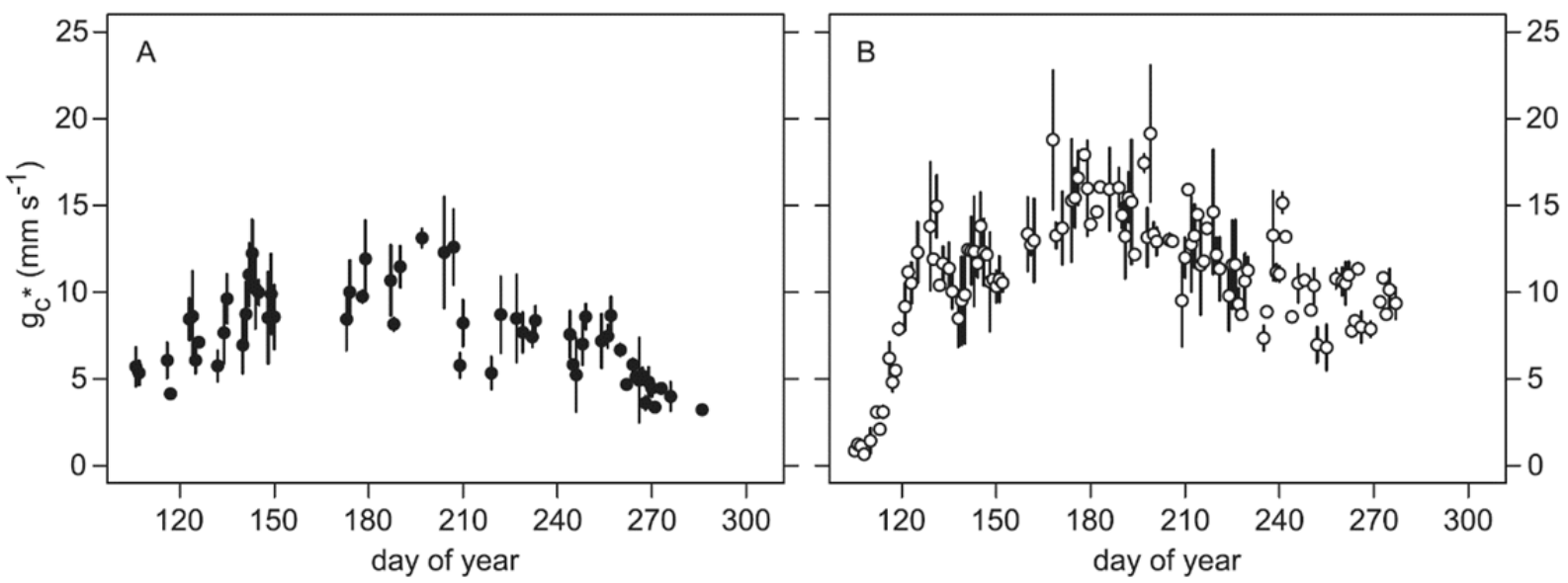

Fig. 5. Daily means (symbols) of canopy conductance ( \pm 1 standard deviation, bars) at Fuhrberg $(A)$ and Großfahner (B), measured under standardized conditions $\left(g_{c}^{*} \mid R_{G} \geq 400 \mathrm{~W} \mathrm{~m}^{-2}, D=1 \pm 0.3 \mathrm{kPa}, u>1 \mathrm{~m} \mathrm{~s}^{-1}, P=0 \mathrm{~mm}\right.$ during past $\left.10 \mathrm{~h}\right)$.

Fig. 6 shows hourly values of canopy conductance as a function of the vapor pressure deficit, separately for each month from May to October. Only hourly $g_{c}$-values are shown that satisfied the following conditions: $R_{\mathrm{G}} \geq 400 \mathrm{Wm} \mathrm{m}^{-2}, u \geq 1 \mathrm{~m} \mathrm{~s}^{-1}, P=0 \mathrm{~mm}$ during past $10 \mathrm{~h}$, i.e. meteorological reference conditions (see above), without the restriction on D. Response curves (Eq. (10)) were fitted to the upper envelopes of the monthly datasets, and Table 3 contains the corresponding parameters from which the water use

Table 3

Parameter estimates $\left(g_{\text {cref, }} m\right.$ ) of the function relating $g_{\mathrm{c}}$ to $D$ (Eq. (10), Fig. 6), and calculated theoretical $\mathrm{m} / \mathrm{g}_{\text {cref }}$-ratios at which stomatal regulation is sufficient to maintain a minimum leaf water potential at high $D$. Significance $(p<0.05)$ of the estimates is indicated by asterisks. For October, no estimates could be obtained due to low $D$.

\begin{tabular}{|c|c|c|c|c|c|c|}
\hline Month & $g_{\text {cref }}\left(\mathrm{mm} \mathrm{s}^{-1}\right)$ & $m\left(\mathrm{~mm} \mathrm{~s}^{-1} \mathrm{kPa}^{-1}\right)$ & $\begin{array}{l}\text { Actual } m / g_{\text {cref }} \\
\left(\mathrm{kPa}^{-1}\right)\end{array}$ & $D$-range ( $\mathrm{kPa})$ & $g_{a}\left(\mathrm{~m} \mathrm{~s}^{-1}\right)$ & $\begin{array}{l}\text { Theoretical } \mathrm{m} / \mathrm{g}_{\text {cref }} \\
\left(\mathrm{kPa}^{-1}\right)\end{array}$ \\
\hline \multicolumn{7}{|l|}{ Fuhrberg } \\
\hline May & $9.98^{*}$ & $3.542^{\circ}$ & 0.355 & $1-2.33$ & 0.046 & 0.773 \\
\hline June & $10.72^{\circ}$ & $2.448^{\circ}$ & 0.228 & $1-2.49$ & 0.057 & 0.722 \\
\hline July & $12.53^{\circ}$ & $5.500^{\circ}$ & 0.439 & $1-2.00$ & 0.043 & 0.822 \\
\hline August & $9.55^{\circ}$ & $7.292^{\circ}$ & 0.764 & $1-1.55$ & 0.040 & 0.956 \\
\hline September & $6.85^{\circ}$ & $4.297^{\circ}$ & 0.627 & $1-2.19$ & 0.041 & 0.784 \\
\hline October & - & - & - & $1-1.09$ & 0.039 & - \\
\hline \multicolumn{7}{|l|}{ Großfahner } \\
\hline May & $13.49^{\circ}$ & $6.350^{\circ}$ & 0.471 & $1-2.28$ & 0.171 & 0.711 \\
\hline June & $16.90^{\circ}$ & $11.146^{\circ}$ & 0.659 & $1-2.24$ & 0.189 & 0.709 \\
\hline July & $16.07^{\circ}$ & $10.805^{\circ}$ & 0.672 & $1-2.50$ & 0.188 & 0.742 \\
\hline August & $14.28^{\circ}$ & $9.785^{\circ}$ & 0.685 & $1-3.17$ & 0.155 & 0.621 \\
\hline September & $11.28^{\circ}$ & $6.881^{\circ}$ & 0.610 & $1-2.44$ & 0.171 & 0.684 \\
\hline October & - & - & - & 0.84 & 0.140 & - \\
\hline
\end{tabular}




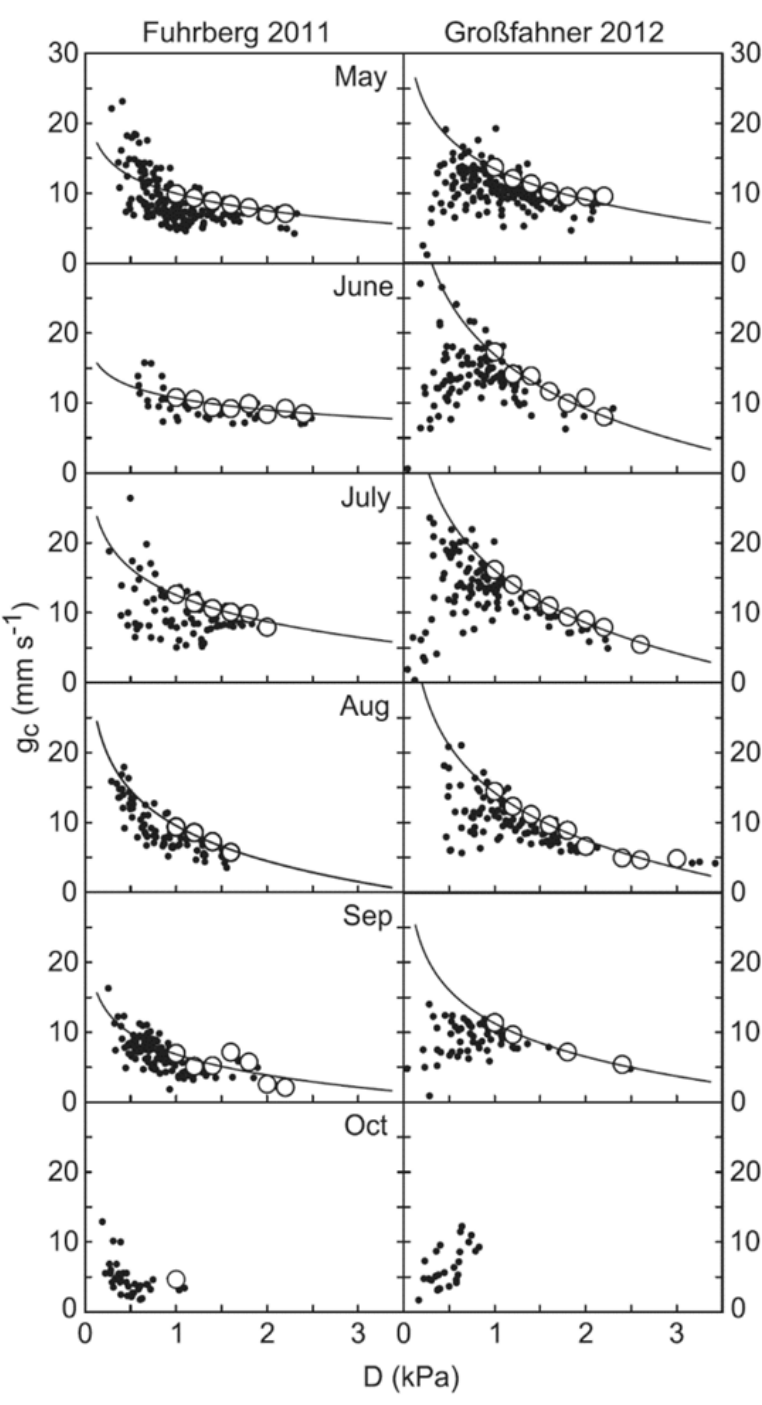

Fig. 6. Mean hourly canopy conductance (dots) of the young (Fuhrberg, left) and mature (Großfahner, right) SRCs, as a function of vapor pressure deficit $(D)$. Only data from the dry canopies, under incoming solar radiation $R_{\mathrm{G}}>400 \mathrm{~W} \mathrm{~m}^{-2}$ and wind speed $u>1 \mathrm{~m} \mathrm{~s}^{-1}$ are shown. Large circles represent upper envelopes of the data clouds, to which Eq. (10) was fitted (lines). In October, the function could not be fitted due to low $D$.

strategy of the poplar plantations can be inferred. At both sites, $g_{c}$ was highest at low vapor pressure deficit and, as a result of stomata closure, decreased with increasing $D$. During most months, the curves at Großfahner appeared steeper than in Fuhrberg, were the curves were flat especially during the first three months. In October, no curve parameters could be estimated due to the low $D$ range.

The reference conductance parameter ( $g_{\text {cref, }}$ Table 3 ) reflects on a monthly basis the seasonal trends of upper boundary canopy conductance observed under reference conditions (Fig. 5), as this parameter defines $g_{c}$ at $D=1 \mathrm{kPa}$. Accordingly, monthly $g_{\text {cref }}$ of the mature plantation was significantly higher $(p=0.00079$, paired $t$-test) compared to the young plantation. The largest discrepancy in $g_{\text {cref }}$ between sites was observed in June, where the corresponding curve at Fuhrberg in Fig. 6 was flatter and on a lower level for $D=1 \mathrm{kPa}$. During the other months, $g_{\text {cref }}$ of the mature

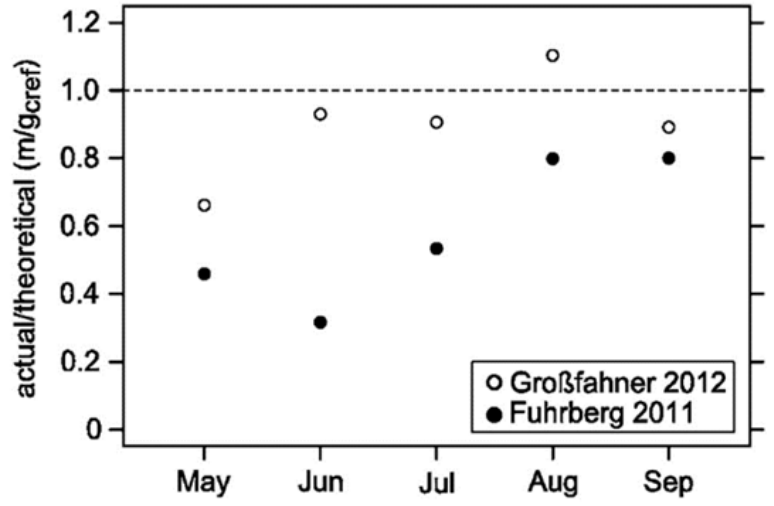

Fig. 7. Ratio of actual $\mathrm{m} / \mathrm{g}$. the climatic conditions at Fuhrberg (solid symbols) and Großfahner (open symbols). The reference line marks perfect isohydric behavior, when stomata response to $D$ is sufficient to regulate minimum leaf water potential.

plantation constantly was about $3.5-4.5 \mathrm{~mm} \mathrm{~s}^{-1}$ higher than at the young plantation, with the greater differences in August and September.

The sensitivity of $g_{\mathrm{c}}$ to increasing $D$ (i.e. the slope of the curve), as measured by the $m$-parameter, increased with increasing $g_{\text {cref }}$ at the full-grown plantation, except for May (Table 3$)$. In May, $g_{c}$ at $D \geq 2 \mathrm{kPa}$ was high compared to other months (Fig. 6) and a comparably flat curve was obtained by the fitting procedure, indicating less strict stomatal control of transpiration. From June, $m / g_{\text {cref }}$ ratios were relatively stable and varied closely around the universal value of an isohydric stomata response (0.6; Oren et al., 1999), sufficient to regulate minimum leaf water potential. For the young plantation, the fitting procedure obtained the highest $m$-value in August, when $g_{\text {cref }}$ was low compared to earlier months. The lowest $m$ value for Fuhrberg was obtained in June, and $\mathrm{m} / \mathrm{g}_{\text {cref }}$ ratios showed a large month-to-month variability. Anyhow, the lowest ratios were obtained from May to July, corresponding to relatively flat response curves (Fig. 6) that indicate a rather loose stomatal control of transpiration during that time.

Despite the differences in stomatal control of water loss, both plantations exhibited isohydric stomata reactions to atmospheric drought at first glance, as the ratios did not differ significantly from the universal ratio of 0.6 (Fuhrberg: $p=0.2867$, Großfahner: $p=0.647$; $t$-test). Notwithstanding, a closer look revealed that the universal ratio was significantly lower than the modeled theoretical ratios, that take the observed $D$-ranges at our sites into account (Table 3; Fuhrberg: $p=0.00589$, Großfahner: $p=0.01003$; one-sample $t$-tests). Thus, statements on water use strategy of the plantations should be based on the theoretical $\mathrm{m} / \mathrm{g}_{\text {cref }}$ ratios that are valid for the rather humid meteorological conditions at our sites, and not on the universal proportionality of 0.6 valid for larger $D$-ranges (Herbst et al., 2008). Fig. 7 shows the actual response in relation to the theoretical isohydric response (Table 3 ) on a monthly basis. For the full-grown plantation, the isohydric response from the comparison with the universal $\mathrm{m} / \mathrm{g}_{\text {cref }}$ ratio of 0.6 was confirmed, actual and theoretical ratios were not different $(p=0.2033$, paired $t$-test). In contrast, observed ratios for Fuhrberg differed significantly from the sitespecific theoretical ratios $(p=0.0075)$, in total indicating a loose stomatal control of transpiration, particularly arising from anisohydric responses during May, June and July. From August, $\mathrm{m} / \mathrm{g}_{\text {cref }}$ ratios of the young plantation indicated more isohydric responses to atmospherical drought, being $80 \%$ of the perfect isohydric proportionality. 


\section{Discussion}

4.1. Accuracy and comparability of transpiration and evapotranspiration measurements

Sap flux-scaled estimations of stand transpiration generally are prone to various random errors related to sampling density and scaling (Granier et al., 2000a), as well as systematic errors arising from invalid calibration coefficients (Steppe et al.. 2010) and the application of TDP sensors in heterogeneous wood (Clearwater et al., 1999). Systematic errors were excluded as far as possible by choosing short sensors to warrant full contact with water conducting sapwood and empirically calibrating Granier's method to our TDP sensor setup. The resulting accumulated stand transpiration $(387 \mathrm{~mm}$ ) was about $120 \mathrm{~mm}$ higher than transpiration calculated with Granier's original coefficients. The magnitude of underestimated $F_{\mathrm{d}}$ by Granier's original calibration was in accordance with Steppe et al., 2010 and shows the need for a individual recalibration, if a deviating sensor setup is chosen.

However, the applied scaling method from mean $F_{\mathrm{d}}$ to stand transpiration via total stand sapwood area assumes uniform sapflow in radial and azimuthal stem directions. Radial flow patterns could not be evaluated, but azimuthal flow variation in stems used for the calibration procedure was relatively small, as suggested by the error bars in Fig. 1. On average, $F_{\mathrm{d}}$ measured by two sensors in the same stem deviated by $20 \%$. If this value is related to the number of sample trees $(n=5)$, the standard error in average $F_{\mathrm{d}}$ is $9 \%$. Assuming an error of $10 \%$ for stand sapwood area estimations and $5 \%$ for the estimated number of stems per hectare, and adding these to the squared potential error in $F_{\mathrm{d}}$ (because $F_{\mathrm{d}}$ and $A_{\text {sapwood }}$ are multiplied), our total stand transpiration estimations are afflicted with an error of $14 \%$. This value is in accordance with Čermák et al. (2004), who found sharply decreasing upscaling errors for sap flux-derived $E_{\mathrm{t}}$ in homogeneous stands, being $15 \%$ at $n=5$ and $10 \%$ at $n=12$ sample trees and. We are confident that both instantaneous transpiration rates, and growing season totals fall within this uncertainty range.

However, uncertainties in total growing season evapotranspiration $(380 \mathrm{~mm})$ from the young plantation are somewhat higher than at Großfahner, due to various sources of error. Apart from partly unfavorable fetch conditions and small gradients that cause uncertainties in $E$ measured by the BREB method, equipment failed for 20 days during June. To obtain total growing season $E$, the resulting data gap was filled from potential evaporation multiplied with the mid-season mean crop coefficient on rainless days, which might have led to an overestimation in total $E$. Crop coefficients are often observed to decrease, when a critical threshold of relative extractable soil water is reached (40\%, Granier et al., 2000a; Petzold et al., 2011). When equipment failed in Fuhrberg, extractable soil water was already at $60 \%$ of its maximum value at field capacity. The data gap coincided with a period of low precipitation and high evaporative demand, and it seems likely that the threshold was undercut, the crop coefficient lowered and $E$ overestimated. A simple water balance calculation suggested that the threshold was undercut approximately 10 days after equipment failure. If soil water became limiting for the rest of the data gap, total $E$ would have been at most $15 \mathrm{~mm}$ less.

Despite the relatively large uncertainties in total $E$, daily crop coefficients on rainless days and hourly canopy conductance estimations of the young SRC can be considered less uncertain, because unfavorable fetch conditions were excluded. Under favorable fetch conditions and dry weather, the Monte-Carlo uncertainty estimation suggested that the error in measured input variables $\Delta T, \Delta e$, $R_{N}, G$ caused standard errors of $5-10 \%$ in the calculation of daily latent heat fluxes, with the smallest errors emerging on days with high evaporative demand.
Although the uncertainties in instantaneous water use rates can be considered quite low for both sites, several more assumptions have to be met in order to compare the water use potential of plant stands across sites and seasons. The differing methods used in this study to estimate water use partly accounted for different vapor fluxes and thus have to be interpreted with caution. Soil evaporation was assumed negligible at the full-grown mature plantation. This assumption can be justified, because soil evaporation has only a small share in total evapotranspiration of dense forests (Kelliher et al., 1993), and the LAI was already above $5 \mathrm{~m}^{2} \mathrm{~m}^{-2}$ when observations started. However, $E_{\mathrm{s}}$ from a wet litter layer can be temporarily enhanced also beneath dense canopies (Kelliher et al., 1993), and we suggest that these were the only situations when considerable amounts of water could have evaporated from the soil covered by leaf litter at the full-grown plantation. Such flux was not measured by the methods applied in Großfahner, but was captured by the Bowen-ratio energy balance method in Fuhrberg. There, high evapotranspiration rates that considerably exceeded potential evaporation were measured on several rainless days after heavy rainfall events (Figs. 3 and 4). The canopy conductances during these conditions were in the range of values observed for the wet canopy, i.e. during the hours after rainfall. We thus can say that these situations, with very high "surface" conductances at Fuhrberg, rather resembled the process of interception evaporation than soil evaporation and correspond to the suggested (not measured) evaporation from a wet leaf litter layer at the fullgrown plantation. By dismissing these values from further analyses at Fuhrberg, but at the same time keeping the normal background soil evaporation and understorey transpiration signal, we believe that the datasets allow for meaningful comparisons of the water use potential of our study sites that differed in leaf area index and canopy closure.

Nevertheless, a comparison of water use potentials across sites and seasons by means of canopy conductance also requires addressing environmental variables with which canopy conductance varies. By defining meteorological reference conditions, we eliminated some atmospherical factors affecting canopy conductance. One factor that could not be controlled by filtering the datasets was relative extractable soil water, which has a negative effect on stomatal conductance of tree species, when dropping below the already mentioned threshold. The threshold was never reached at Großfahner, where minimum REW of all measuring depths was $55 \%$, observed at $20 \mathrm{~cm}$ soil depth at the end of September. Additionally, the poplar trees had access to a groundwater table. At Fuhrberg, the threshold was probably undercut during the data gap in June, but SWC was subsequently refilled and no severe water stress occurred until the end of the observation period. For these reasons, we believe that a comparison of canopy conductance across seasons can be justified.

\subsection{Water use patterns}

Growing season mean transpiration of $2.35 \mathrm{~mm}$ and accumulated evapotranspiration of $445 \mathrm{~mm}$ (Fig. 3, Table 2) for the mature plantation agreed well with water use rates reported for other poplar SRCs in Europe (Fischer et al., 2013; Meiresonne et al., 1999; Migliavacca et al., 2009). Transpiration did not differ from transpiration of deciduous forest in central Europe $(350-400 \mathrm{~mm}$, Herbst et al., 2008), and main growing season $g_{c}^{*}$ at $10-17 \mathrm{~mm} \mathrm{~s}^{-1}$ was in the range of values reported for forests with LAI $>5 \mathrm{~m}^{2} \mathrm{~m}^{-2}$ (Granier et al., 2000b). Maximum $E_{\mathrm{t}}\left(4.5 \mathrm{~mm} \mathrm{~d}^{-1}\right)$ and growing season total $E_{\mathrm{t}}(387 \mathrm{~mm})$ yet was slightly lower compared to a poplar SRC with "Max 1" clones, growing on a similar soil but receiving higher amounts of rainfall (Petzold et al., 2011). On that site, low soil temperatures at the beginning of the growing season, and soil drought during the main season reduced transpiration ratios and 
hampered the full exploitation of the biomass production potential of the poplar cultivar. In contrast, water availability was not limiting transpiration severely at our full-grown mature plantation, as indicated by relatively stable crop coefficients around 1.0 on rainless days throughout the main growing season (Fig. 4A). In comparison to other SRCs, transpiration seemed low for these conditions. Where water is abundant, significantly higher transpiration can be measured in SRCs, as shown by high maximum transpiration rates above $10 \mathrm{~mm} \mathrm{~d}^{-1}$, reported for clone "Beaupre" growing on sites in South England (Hall and Allen, 1997; Hall et al., 1998). There, evaporative demand was somewhat higher than at our site, but the transpiration ratio (corresponding to the $E_{\mathrm{t}}$-derived crop coefficients at Großfahner) still was well above 1.5 for most of the time, before it decreased to very low values with increasing soil water deficits (Hall et al., 1998). Our clone "J-105" did not show such excessive transpiration rates; growing season total transpiration and crop coefficient rather agreed well with recently reported values for the same poplar hybrid from central Europe (Fischer et al., 2013) that used, at an annual basis, less water than a neighboring grassland site.

Transpiration, crop coefficients, and canopy conductance under reference conditions sharply increased with foliation in spring and decreased with leaf fall in autumn at the mature plantation, while water use of the young SRC site in Fuhrberg differed from this typical seasonal pattern (Figs. 3-5). There, water use measured by the BREB method was relatively high from the beginning of the observation period, although leaf area was low and stagnated at least until the end of June on a relatively low level $\left(\approx 2 \mathrm{~m}^{2} \mathrm{~m}^{-2}\right.$, Fig. 2$)$, due to a late frost event, insect herbivory and perhaps as well soil drought. Canopy conductance $\left(g_{c}^{*}\right)$ at $7-12 \mathrm{~mm} \mathrm{~s}^{-1}$ during that time appears high when compared to sap flux-derived $g_{c}^{*}$ of forests with similar LAI of 2-3 $\mathrm{m}^{2} \mathrm{~m}^{-2}$ (Granier et al., 2000b). However, the BREB method also accounts for vapor fluxes other than tree transpiration, and high early-season $E / \mathrm{ET}_{0}$ and $g_{c}^{*}$ at low LAI probably reflected the contribution of understorey transpiration and soil evaporation to measured evapotranspiration. The young poplar trees might have started relatively late to contribute significantly to evapotranspiration (e.g. by mid-May after having recovered from the late frost). Kelliher et al. (1995) showed that maximum bulk canopy conductance, a proxy for $g_{c}^{*}$, is conservative against LAI, because ground vegetation and soil evaporation compensate for low overstorey transpiration at an LAI $<3 \mathrm{~m}^{2} \mathrm{~m}^{-2}$. Correspondingly, we suggest that there was a gradual shift from understorey- $E_{\mathrm{t}}$ and $E_{\mathrm{s}}$ to tree transpiration during the first half of the growing season, with the tree transpiration becoming increasingly important with increasing LAI. By the end of July, the young poplar trees had developed a more dense and closed canopy $\left(\mathrm{LAI}>3 \mathrm{~m}^{2} \mathrm{~m}^{-2}\right)$, therefore tree transpiration probably was dominant over understorey transpiration and soil evaporation from August at the young site.

Although it is difficult to estimate the relative contributions of understorey- $E_{\mathrm{t}}$ and $E_{\mathrm{s}}$ to evapotranspiration, these considerations show the need to account for such fluxes, when addressing water use of SRCs with low leaf area and a sparse canopy. A hint for the importance of understorey- $E_{\mathrm{t}}$ and soil evaporation for overall stand water use can be found by comparing our results to an earlier mentioned study: The mid-season crop coefficient $(\approx 0.8)$ on rainless days at the young site agreed well with the transpiration ratios for one of the two clones that Allen et al. (1999) measured using the sap flux method. However, leaf area of our young poplar trees in the first half of the growing season rather resembled LAI of the second clone $\left(\mathrm{LAI} \approx 2 \mathrm{~m}^{2} \mathrm{~m}^{-2}\right)$. This second clone ("Dorschkamp") displayed lower transpiration ratios (0.4-0.6) than our young SRC, eventually pointing to the part that understorey transpiration soil evaporation and contributed to evapotranspiration in the first half of the growing season. Persson and Lindroth (1994) estimated $E_{\mathrm{S}}$ to account for $44 \%$ of total growing season evapotranspiration in a willow SRC, where the seasonal course of leaf area development and maximum LAI for one season was comparable to our young SRC. However, their willow field was drip-irrigated and the conditions may not be comparable to Fuhrberg, with its sandy soil and understorey vegetation. Nevertheless, understorey transpiration and soil evaporation together might have contributed in a similar magnitude to measured evapotranspiration at our site, at least during the first half of the season in Fuhrberg, before the poplar canopy was closed.

\subsection{Canopy conductance and water use strategies}

Our full-grown mature SRC showed efficient stomatal regulation of transpiration in response to increasing vapor pressure deficits. The regulatory mechanism seemed sufficient to maintain the leaf water potential on a minimum level (Fig. 7), and indicated a conservative, stress avoiding isohydric water use strategy that limited transpiration rates even though water supply was ample. Stomatal control is species specific, and the efficient regulation of transpiration might be typical for the clone "J-105", and also responsible for comparably low water use of this hybrid reported by other authors (Fischer et al., 2013). Such strict stomatal regulation of transpiration was also shown in another study (Migliavacca et al., 2009), where water supply from a shallow water table was ample and evaporative demand was high. Nevertheless, risky water use strategies marked by only weak stomatal response to increasing evaporative demand and dropping leaf water potentials are reported from investigations of poplar water relations at the leaf scale (Blake et al., 1984; Larchevêque et al., 2011). Anyway, there are hints in the previous literature that such water use strategy can actually be observed at the stand scale with only weak stomatal response to increasing evaporative demand (clone "Beaupre", Allen et al., 1999; Hall et al., 1998) facilitating very high transpiration rates. This was not the case for our mature plantation, other poplar hybrids however might have used considerably more water at the Großfahner site than "J-105".

At Fuhrberg, it was not possible to infer the water use strategies of the individual poplar hybrids of which the young plantation was made up ("Max 1", "Androscoggin”, “AF2"), due to the applied measuring technique (BREB). However, the plantation as a whole displayed an isohydric water use strategy like "J-105" at Großfahner, but only after the canopy had reached an LAI of $3 \mathrm{~m}^{2} \mathrm{~m}^{-2}$, and tree transpiration probably was dominant over understorey transpiration and soil evaporation. Before, the young plantation as a whole exhibited a rather anisohydric behavior (Fig. 7). This behavior is indicated by less efficient stomatal control of water loss and supports the suggestion of increased contribution of understorey$E_{\mathrm{t}}$ and soil evaporation to measured evapotranspiration at the young site before canopy closure: Vapor pressure deficit has no direct feedback effect on the conductance for water vapor from the soil. Considerable amounts of $E_{\mathrm{s}}$ would therefore theoretically shift the observed responses of $g_{c}$ to $D$ (Fig. 6) in vertical direction, and thus lower the $\mathrm{m} / \mathrm{g}_{\text {cref }}$ ratio to the anisohydric region. Understorey vegetation might also lower the ratio, as understorey$E_{\mathrm{t}}$ tends to simply follow the actual amount of available energy below the tree canopy (McNaughton and Jarvis, 1983). Roberts et al. (1980) showed that transpiration from bracken in the understorey of a sparse pine overstorey usually accounted for $25 \%$ of total stand transpiration, and could increase to $50 \%$ in times of low atmospheric humidity. This was due to an insensitivity of the bracken stomatal conductance to vapor pressure deficit, while tree transpiration was limited during such conditions. The effect of loose stomatal control of evapotranspiration from the young site can be seen in the differences between $E / \mathrm{ET}_{0}$ and canopy conductance under reference conditions: while differences in crop coefficients between sites (Fig. 4) were low, $g_{c}^{*}$ and $g_{\text {cref }}$ (Fig. 5, Table 3) were significantly higher at the mature plantation. This points to a higher water use 
potential of the full-grown plantation, and similar crop coefficients are a result of differences in stomatal regulation of water loss in combination with differences in evaporative demand between the 'sites. If stomatal regulation and evaporative demand would have been similar between sites throughout the growing season, water use from the full-grown plantation would have been significantly higher. The variables $g_{\mathrm{c}}^{*}$ and $g_{\text {cref }}$ define $g_{\mathrm{c}} @ 1 \mathrm{kPa}$, and an ineffi'cient stomatal control of water loss at the young site thus must have caused high water loss at high evaporative demand, in the end leading to almost similar crop coefficients. This effect in theory becomes all the more marked, the higher $D$ is. Understorey- $E_{\mathrm{t}}$ and $E_{\mathrm{s}}$ might therefore even over-compensate low overstorey transpiration at low LAI, if water supply is not limiting evapotranspiration.

\subsection{Implications for management}

The observed anisohydric water use strategy at the young plantation before canopy closure, probably caused by increased importance of understorey transpiration and soil evaporation for total stand water use, compensated for lower tree transpiration and led to similar crop coefficients on rainless days between the two study sites. More frequent harvests, the choice of a wider planting scheme and other management strategies to constrain canopy cover therefore seem not to be suited to mitigate negative impacts on local hydrology, aside from a possible reduction of rainfall interception evaporation (Dimitriou et al., 2009). However, efficient weed control would yet increase the water-efficiency of short rotation coppices with low canopy cover and leaf area, due to reduced competition for water resources (Otto et al., 2010). In many temperate forest ecosystems, the understorey vegetation is developed early in spring, while LAI development of the overstorey and the physiological differentiation of leaves considerably lag behind the seasonal increase of available energy (Morecroft and Roberts, 1999). This applies even more for SRCs that are in a resprouting phase once every few years after harvest, with a closed canopy yet to develop and an active understorey present in the stand. In case of a spring or early summer drought, which might occur more frequently in a changing environment, soil water deficits might develop earlier in the growing season and could inhibit a fast resprouting of cut trees, resulting in yield reductions.

The closed poplar canopies at both of our plantations showed an isohydric behavior limiting transpiration during periods of high evaporative demand. Canopy conductance under reference conditions was higher at the full-grown plantation with very high LAI pointing to a higher transpiration water use potential of plantations with high leaf area, and thus probably stronger impacts on local hydrology than plantations with lower leaf area. However, a much more determining factor for negative hydrological impacts through high water consumption is the water use strategy of the cultivated clone. A conservative water use strategy as observed for "J-105" on the one hand avoids transpiration rates from exceeding the feasible water supply rate on the soil-to-leaf pathway by stomatal adjustment, helping the plant hydraulic system to maintain its functionality over long periods of high evaporative demand (Aranda et al., 2012). As well, it enables the plants to save water during times of ample water supply, and eventually occurring future soil water stress is postponed or even avoided. On the other hand, stomata closure during atmospherical drought also affects the purpose of SRC cultivation (i.e. biomass production), by inhibiting the diffusion of carbon dioxide into the leaf (Migliavacca et al., 2009). A rather risky water use strategy with loose stomatal control of transpiration, imposing little restriction to evaporative demand would in turn gain higher biomass yields under atmospherical drought as long as water resources are available. However, yield declines impend for such clones when water supply ceases, due to potential hydraulic failure of the water conducting tissue. In order to develop ecologically sustainable and economically beneficial management schemes for SRC biomass production under given pedo-climatic conditions, it is therefore crucial to take the water use strategy of the individual clones into account, and carefully select adequate plant material. For example, the investigated clone "J-105" would probably perform well on sites with less abundant water supply than at Großfahner, due to its conservative, drought-avoiding water use strategy. In contrast, clones with less strict stomatal control of transpiration would perhaps gain lower yields on such sites, because of their higher vulnerability to severe drought stress. In turn, these clones would gain higher yields where water is abundant, but also would use more water than "J-105", which might be a problem at sites where negative impacts on local hydrology have to be mitigated. Where water is precious, clones with conservative water use strategies like the investigated " $\mathrm{J}-105$ " should thus be preferred for cultivation.

However, information on individual water relations of the various clones having legal authority to use in woody biomass production is scarce. If area requirements for SRC increase significantly in a water-limited world, poplar hybrids and other woody species should be labeled according to their water use strategy, as is the case for food crops and vegetables (Limpus, 2009). With this information, stakeholders would have the possibility to make the appropriate choice of plant material, by taking the given and expected future environmental and social conditions of a potential biomass production site into account.

\section{Conclusions}

Our results suggested that some aspects of Roberts' hypothesis (1983) about forest transpiration being a conservative quantity seem to be valid as well for poplar plantations that are cultivated in short rotation for the production of woody biomass. Water use between the two study sites did not differ substantially despite considerable differences in leaf area and canopy cover. Before canopy closure, understorey transpiration and soil evaporation compensated for lower tree transpiration at the young plantation. There was a shift from a rather anisohydric water use strategy to an isohydric strategy in the young SRC, which was most likely caused by the decreasing importance of understorey transpiration and soil evaporation with canopy closure. The anisohydric behavior was indicated by a less strict regulation of transpiration in response to $D$ and caused high water losses at high evaporative demand, which was identified as a reason for the lack of differences in water use between the open and closed canopies. The full-grown plantation displayed isohydric behavior throughout the growing season with efficient stomatal control of water loss that resulted in moderate transpiration rates even under ample water supply. The investigated poplar hybrid "J-105" thus seems to be well suited for biomass production in water sensitive areas, where biomass yield should not be maxed at the expense of strong negative impacts on local hydrology.

\section{Acknowledgments}

The authors are grateful to the Hanover water authorities (Stadtwerke Hannover AG; www.enercity.de), to the Agency for Renewable Resources (FNR e.V;. www.fnr.de) and to the European ERA-NET-Bioenergy program for funding this study. We give our special thanks to D. Fellert for his valuable advice and assistance in handling the meteorological equipment, to D. Böttger for his field assistance, to $\mathrm{K}$. Lorenz for providing LAI-measurements for the full-grown plantation and S. Fuchs for conducting the TDP sensor calibrations. 


\section{References}

Allen, R.G., Pereira, L.S., Raes, D., Smith, M., 1998. Crop evapotranspiration: guidelines for computing crop water requirements. FAO Irrigation and Drainage Paper 56, pp. 290.

Allen, S.J., Hall, R.L., Rosier, P.T.W., 1999. Transpiration by two poplar varieties grown as coppice for biomass production. Tree Physiol. 19, 493-501.

Almeida-Rodriguez, A.M. Cooke, J.E.K. Yeh, F. Zwiazek, JJ. 2010. Functional characterization of drought-responsive aquaporins in Populus balsamifera and Populus simonii $\times$ balsamifera clones with different drought resistance strategies. Physiol. Plant 140, 321-333.

Aranda, I., Forner, A., Cuesta, B., Valladares, F., 2012. Species-specific water use by forest tree species: From the tree to the stand. Agric. Water Manag. 114, 67-77.

Arneth, A., Kelliher, F.M., Bauer, G., Hollinger, D.Y., Byers, J.N., Hunt, J.E., McSeveny, T.M., Ziegler, W., Vygodskaya, N.N., Milukova, I., Sogachov, A., Varlagin, A., Schulze, E.-D., 1996. Environmental regulation of xylem sap flow and total conductance of Larix gmelinii trees in eastern Siberia. Tree Physiol. 16, 247-255.

Blake, T.J., Tschaplinski, T.J., Eastham, A., 1984. Stomatal control of water use efficiency in poplar clones and hybrids. Can. J. Bot. 62, 1344-1351.

Busch, G., 2009. The impact of Short Rotation Coppice cultivation on groundwater recharge-a spatial (planning) perspective. Landbauforsch. - VTI Agric. For. Res. 3(59). 207-222.

Businger, J.A., 1956. Some remarks on Penman's equation for the evaporation. Neth. J. Agric. Sci., 77-80.

Čermák, J., Kučera, J., Nadezhdina, N., 2004. Sap flow measurements with some thermodynamic methods, flow integration within trees and scaling up from sample trees to entire forest stands. Trees 18, 529-546.

Ceulemans, R., Impens, I., Imler, R., 1988. Stomatal conductance and stomatal behavior in Populus clones and hybrids. Can. J. Bot. 66, 1404-1414.

Clearwater, M.J., Meinzer, F.C., Andrade, J.L., Goldstein, G., Holbrook, N.M., 1999 Potential errors in measurement of nonuniform sap flow using heat dissipation probes. Tree Physiol. 19, 681-687.

Dimitriou, I., Busch, G.., Jacobs, S., Schmidt-Walter, P., Lamersdorf, N., 2009. A review of the impacts of Short Rotation Coppice cultivation on water issues, Landbauforsch. -VTI Agric. For. Res. 3, 197-206.

Djomo, S.N., Kasmioui, O.E., Ceulemans, R., 2011. Energy and greenhouse gas balance of bioenergy production from poplar and willow: a review. GCB Bioenergy 3 , of bioenergy $181-197$.

Elsawwaf, M., Willems, P., Pagano, A., Berlamont, J., 2010. Evaporation estimates from Nasser Lake, Egypt, based on three floating station data and Bowen ratio energy budget. Theor. Appl. Climatol. 100, 439-465.

Ewers, B.E., Gower, S.T., Bond-Lamberty, B., Wang, C.K., 2005. Effects of stand age and tree species on canopy transpiration and average stomatal conductance of boreal forests. Plant Cell Environ. 28, 660-678.

Fischer, M., Trnka, M., Kučera, J., Deckmyn, G., Orság, M., Sedlák, P., Žalud, Z., Ceulemans, R.. 2013. Evapotranspiration of a high-density poplar stand in comparison with a reference grass cover in the Czech-Moravian Highlands. Agric. For. Meteorol. 181, 43-60.

Foken, T., Richter, S.H., Müller, H., 1997. Zur Genauigkeit der Bowen-Ratio-Methode. Wetter Leben 49, 57-77.

Granier, A., 1985. Une nouvelle méthode pour la mesure du flux de sève brute dans le tronc des arbres (A new method of sap flow measurement in tree stems). Ann. Sci. For. 42, 193-200

Granier, A., Loustau, D., Breda, N., 2000a. A generic model of forest canopy conductance dependent on climate, soil water availability and leaf area index. Ann. For Sci. $57,755-765$

Granier, A., Biron, P., Lemoine, D., 2000b. Water balance, transpiration and canopy conductance in two beech stands. Agric. For. Meteorol, 100, 291-308.

Hall, R.L., Allen, S.J., 1997. Water use of poplar clones grown as short-rotation coppice at two sites in the United Kingdom. Presented at the Aspects of Applied Biology, pp. 163-172.

Hall, R.L., Allen, S.J., Rosier, P.T.W., Hopkins, R., 1998. Transpiration from coppiced poplar and willow measured using sap-flow methods. Agric. For. Meteorol. 90, 275-290.

Heilman, J.L., Brittin, C.L., Neale, C.M.U., 1989. Fetch requirements for bowen ratio measurements of latent and sensible heat fluxes. Agric. For. Meteorol. 44, 261-273.

Herbst, M., Rosier, P.T.W., Morecroft, M.D., Gowing, D.J., 2008. Comparative measurements of transpiration and canopy conductance in two mixed deciduous woodlands differing in structure and species composition. Tree Physiol. 28 959-970.

James, S.A., Clearwater, M.J., Meinzer, F.C., Goldstein, G., 2002. Heat dissipation sensors of variable length for the measurement of sap flow in trees with deep sapwood. Tree Physiol. 22, 277-283.

Jarvis, P.G., McNaughton, K.G., 1986. Stomatal control of transpiration: scaling up from leaf to region. Adv. Ecol. Res. 15, 1-49.

Jug, A., Hofmann-Schielle, C., Makeschin, F., Rehfuess, K.E., 1999. Short-rotation plantations of balsam poplars, aspen and willows on former arable land in the Federa Republic of Germany. II. Nutritional status and bioelement export by harvested shoot axes. For. Ecol. Manag. 121, 67-83.

Kelliher, F.M., Leuning, R., Schulze, E.D., 1993. Evaporation and canopy characteristics of coniferous forests and grasslands. Oecologia 95, 153-163.
Kelliher, F.M., Leuning, R., Raupach, M.R., Schulze, E.-D., 1995. Maximum conductances for evaporation from global vegetation types. Agric. For. Meteorol. 73 , $1-16$.

King, J.S., Ceulemans, R., Albaugh, J.M., Dillen, S.Y., Domec, J.-C., Fichot, R., Fischer, M., Leggett, Z., Sucre, E., Trnka, M., Zenone, T., 2013. The challenge of lignocellulosic bioenergy in a water-limited world. BioScience 63, 102-117.

Körner, C., 1994. Leaf diffusive conductances in the major vegetation types of the globe. In: Schulze, P.D.E.-D., Caldwell, P.D.M.M. (Eds.), Ecophysiology of Photosynthesis, Springer Study Edition. Springer, Berlin Heidelberg, pp. 463-490.

Larchevêque, M., Maurel, M.. Desrochers, A., Larocque, G.R., 2011. How does drought tolerance compare between two improved hybrids of balsam poplar and an unimproved native species? Tree Physiol. 31, 240-249.

Linderson, M.-L., Iritz, Z., Lindroth, A., 2007. The effect of water availability on stand-level productivity, transpiration, water use efficiency and radiation use efficiency of field-grown willow clones. Biomass Bioenergy 31, 460-468.

Lindroth, A., Băth, A., 1999. Assessment of regional willow coppice yield in Sweden on basis of water availability. For. Ecol. Manag. 121, 57-65.

Lu, P., Urban, L., Zhao, P., 2004. Granier's thermal dissipation probe (TDP) method for measuring sap flow in trees: theory and practice. ACTA Bot. Sin.-Engl. Ed. 46, 631-646.

Martin, T.A., Brown, K.J., Cermák, J., Ceulemans, R., Kucera, J., Meinzer, F.C., Rombold, J.S., Sprugel, D.G., Hinckley, T.M., 1997. Crown conductance and tree and stand transpiration in a second-growth Abies amabilis forest. Can. J. For. Res. 27. 797-808.

McNaughton, K.G., Jarvis, P.G., 1983. Predicting effects of vegetation changes on transpiration and evaporation. In: Kozlowski, T.T. (Ed.), Water Deficits and Plant Growth, vol. VII. Academic Press, pp. 1-47.

Meiresonne, L., Nadezhdin, N., Cermak, J., Van Slycken, J., Ceulemans, R., 1999. Measured sap flow and simulated transpiration from a poplar stand in Flanders (Belgium). Agric. For. Meteorol. 96, 165-179

Migliavacca, M., Meroni, M., Manca, G., Matteucci, G., Montagnani, L., Grassi, G., Zenone, T., Teobaldelli, M., Goded, I., Colombo, R., Seufert, G., 2009. Seasonal and interannual patterns of carbon and water fluxes of a poplar plantation under peculiar eco-climatic conditions. Agric. For. Meteorol. 149, 1460-1476.

Monteith, J.L., 1965. Evaporation and environment. Symp. Soc. Exp. Biol. 19, 205-224.

Morecroft, M.D., Roberts, J.M., 1999. Photosynthesis and stomatal conductance of mature canopy Oak (Quercus robur) and Sycamore (Acer pseudoplatanus) trees throughout the growing season. Funct. Ecol. 13, 332-342.

Naithani. KJ. Ewers, B.E. Pendall, E. 2012. Sap flux-scaled transpiration and stomatal conductance response to soil and atmospheric drought in a semi-arid sagebrush ecosystem. J. Hydrol. 464-465, 176-185.

Oren, R., Sperry, J.S., Katul, G.G., Pataki, D.E., Ewers, B.E., Phillips, N., Schäfer, K.V.R., 1999. Survey and synthesis of intra- and interspecific variation in stomatal sensitivity to vapour pressure deficit. Plant Cell Environ. 22, 1515-1526.

Otto, S., Loddo, D., Zanin, G., 2010. Weed-poplar competition dynamics and yield loss in Italian short-rotation forestry. Weed Res. 50, 153-162.

Pataki, D.E., Oren, R., 2003. Species differences in stomatal control of water loss at the canopy scale in a mature bottomland deciduous forest. Adv. Water Resour. $26,1267-1278$.

Persson, G., Lindroth, A., 1994. Simulating evaporation from short-rotation forest: variations within and between seasons. J. Hydrol. 156, 21-45.

Petzold, R., Schwärzel, K., Feger, K.-H., 2011. Transpiration of a hybrid poplar plantation in Saxony (Germany) in response to climate and soil conditions. Eur. J. For. Res. 130, 695-706.

Roberts, J., Pymar, C.F., Wallace, J.S., Pitman, R.M., 1980. Seasonal changes in leaf area, stomatal and canopy conductances and transpiration from bracken below area, stomatal and canopy conductances

Roberts, J., 1983. Forest transpiration: A conservative hydrological process? J. Hydrol. 66, 133-141

Schmidt-Walter, P., Lamersdorf, N., 2012. Biomass production with willow and poplar short rotation coppices on sensitive areas-The impact on nitrate leaching and groundwater recharge in a drinking water catchment near Hanover, Germany. BioEnergy Res, 3, 1-17.

Sonntag, D., 1990. Important new Values of the Physical Constants of 1986, Vapour Pressure Formulations based on ITS-90, and Psychrometer Formulae, Z. Für Meteorol. 40, 340-344

Stephens, W., Hess, T., Knox, J., 2001. Review of the effects of energy crops on hydrology. Report to MAFF, Institute of Water and the Environment, Cranfield University, Silsoe.

Steppe, K., De Pauw, D.J.W., Doody, T.M., Teskey, R.O., 2010. A comparison of sap flux density using thermal dissipation, heat pulse velocity and heat field deformation methods. Agric. For. Meteorol. 150, 1046-1056.

Tardieu, F., Simonneau, T., 1998. Variability among species of stomatal control under fluctuating soil water status and evaporative demand: modelling isohydric and anisohydric behaviours. J. Exp. Bot. 49, 419-432

Limpus, S., 2009. Isohydric and anisohydric behavior of vegetable crops. Report PR09-4248, The Department of Primary Industries and Fisheries, Queensland. $\mathrm{Au}$.

Zhang, H., Morison, J.I.L., Simmonds, L.P., 1999. Transpiration and water relations of poplar trees growing close to the water table. Tree Physiol. 19, 563-573. 
48. Crow P, Houston TJ (2004) The influence of soil and coppice cycle on the rooting habitat of short rotation poplar and willow coppice. Biomass Bioenergy 26:497-505

49. Thrän D, Edel M, Seidenberger T (2009) Identifizierung strategischer Hemmnisse und Entwicklung von Lösungsansätzen zur Reduzierung der Nutzungskonkurrenzen beim weiteren Ausbau der energetischen Biomassenutzung. 1. Zwischenbericht. Technical report, Deutsches Biomasseforschungszentrum (DBFZ)

50. Hajkova Z (2011) Pappeln mit neuen Methoden züchten. Gesunde Pflanzen Mitteilungen aus der Presse 63:205-209. doi:10.1007/ s10343-011-0267-5

51. Fritsche UR, Hennenberg KJ, Wiegeman K, Herrera R, Franke B, Köppen S, et al. (2010) Bioenergy environmental impact analysis (bias): analytical framework. Technical report

52. Busch G (2009) The impact of short rotation coppice cultivation on groundwater recharge-a spatial (planning) perspective. Landbauforschung - vTI Agric For Res 3(59):207-222

53. Baum S, Weih M, Busch G, Kroiher F, Bolte A (2009) The impact of short rotation coppice plantations on phytodiversity. Landbauforschung - vTI Agric For Res 3(59):163-170

54. Schulz U, Brauner O, Gruß H (2009) Animal diversity on shortrotation coppices - a review. vTI Agric For Res 59(3):171-181

55. Scholz VG, Heiermann M, Kern J, Balasus A (2011) Environmental impact of energy crop cultivation. Umweltwirkungen des Energiepflanzenanbaus. Arch Agron Soil Sci 57:1-33

56. Weih M, Karacic A, Munkert H, Verwijst T, Diekmann M (2003) Influence of young poplar stands on floristic diversity in agricultural landscapes (Sweden). Basic Appl Ecol 4:149-156

57. WFD (2000) Water Framework Directive 2000/60/EC of the European Parliament and of the Council establishing a framework for the Community action in the field of water policy

58. Gadgil M, Ranjit Daniels RJ, Ganeshaiah KN, Narendra Prasad S, Murthy MSR, Jha CS et al (2011) Mapping ecologically sensitive, significant and salient areas of western ghats: proposed protocols and methodology. Curr Sci 100(2):175-182

59. Aronsson PG, Bergström LF, Elowson SNE (2000) Long-term influence of intensively cultured short-rotation willow coppice on nitrogen concentrations in groundwater. Aust J Environ Manag 58(2): 135-145

60. Goodlass G, Green M, Hilton B, McDonough S (2007) Nitrate leaching from short-rotation coppice. Soil Use Manag 23(2):178-184
61. Mortensen J, Nielsen KH, JØrgensen U (1998) Nitrate leaching during establishment of willow (Salix viminalis) on two soil types and at two fertilization levels. Biomass Bioenergy 15(6):457-466

62. Müller J (1996) Beziehungen zwischen Vegetationsstrukturen und Wasserhaushalt in Kiefern- und Buchenökosystemen. Mitteilungen der Bundeforschungsanstalt Forst- und Holzwirtschaft 185:112122

63. Renger M, Strebel O, Wessolek G, Duynisveld WHM (1986) Evapotranspiration and groundwater recharge - a case study for different climate, crop patterns, soil properties, and groundwater depth conditions. J Plant Nutr Soil Sci 149:371-381

64. Jarvis PG (1985) Coupling of transpiration to the atmosphere in horticultural crops: the omega factor. Acta Horticult 171:187-205

65. Ettala M (1988) Evapotranspiration from a Salix aquatica plantation at a sanitary landfill. Aqua Fennica 18:3-14

66. Linderson M-L, Iritz Z, Lindroth A (2007) The effect of water availability on stand-level productivity, transpiration, water use efficiency and radiation use efficiency of field-grown willow clones. Biomass Bioenergy 31(7):460-468

67. Weih M (2001) Evidence for increased sensitivity to nutrient and water stress in a fast-growing hybrid willow compared with a natural willow clone. Tree Physiol 21:1141-1148

68. Dimitriou I, Aronsson P (2004) Nitrogen leaching from shortrotation willow coppice after intensive irrigation with wastewater. Biomass Bioenergy 26(5):433-441

69. Zechmeister-Boltenstern S, Hahn M, Meger S, Jandl R (2002) Nitrous oxide emissions and nitrate leaching in relation to microbial biomass dynamics in a beech forest soil. Soil Biol Biochem 34 (6): $823-832$

70. Wolf R (2011) Freisetzung von Spurengasen $\left(\mathrm{CO}_{2}, \mathrm{CH}_{4}\right.$ und $\left.\mathrm{N}_{2} \mathrm{O}\right)$ und Kohlenstoffakkumulation in Kurzumtriebsplantagen im Fuhrberger Feld. Master's thesis, University of Göttingen

71. Drewer J, Finch JW, Lloyd CR, Baggs EM, Skiba U (2011) How do soil emissions of $\mathrm{N}_{2} \mathrm{O}, \mathrm{CH}_{4}$ and $\mathrm{CO}_{2}$ from perennial bioenergy crops differ from arable annual crops? GCB Bioenergy 4(4):408419

72. Gauder M, Butterbach-Bahl K, Graeff-Hönninger S, Claupein W, Wiegel R (2011) Soil-derived trace gas fluxes from different energy crops - results from a field experiment in Southwest Germany. GCB Bioenergy 4(3):289-301 


\section{Chapter 4}

An R-package for simulating water fluxes, soil moisture and drought stress using the LWF-Brook90 hydrological model

Paul Schmidt-Walter, Volodymyr Trotsiuk, Katrin Meusburger, Henning Meesenburg

Preprint, accepted 27 April 2020 by Agricultural and Forest Meteorology

https://doi.org/10.1016/j.agrformet.2020.108023 


\section{Software availability}

The LWFBrook90R source code is publicly available at https://github.com/pschmidtwalter/LWFBrook90R and runs with $\mathrm{R}>=3.1 .0$. The package imports functionality from R-packages data.table, vegperiod, sirad, foreach, doSNOW and snow, which can be installed from CRAN.

\subsection{Introduction}

The water budgets and soil water availability play key roles for the productivity and vitality of terrestrial ecosystems and are becoming increasingly important against the background of climate change. Especially in forests, where ecosystem services are provided in long periods spanning decades to centuries, information about future water availability and drought risk is crucial, as these factors determine future species suitability and productivity (Engelbrecht et al., 2007; Kelly and Goulden, 2008). The ecosystem water balance is characterised by complex interactions between climate, soil and vegetation. Process-based models have proven to be capable of adequately describing these processes (Walko et al., 2000). These so-called soil vegetation atmosphere transport (SVAT) models therefore are important tools for understanding and predicting water fluxes, water availability and drought stress, and are integral parts of climate impact assessment studies aimed at determining future ecosystem services and growth conditions of forests (Cáceres et al., 2015).

Sensitivity analysis, model calibration and forward simulations are important tasks in climate impact assessment. Sensitivity analysis and model calibration allow for an efficient estimation of model parameters and their uncertainties referenced by observations. Reliable and robust parameter sets, in turn, are key prerequisites for forward simulations aiming at predicting the bounds of system behaviour in a future climate, beyond observations. However, the application of numerical SVAT models for climate impact assessment is challenging, as the models often still require a perceptible amount of computation time for running on a single location. Consequently, forward simulations for multiple locations over long timespans using various climate projection scenarios often require the implementation of parallel processing.

Parallel processing can also be used in sensitivity analyses to evaluate the effects of the numerous model parameters on model output variability (Pianosi et al., 2016) by exploring the feasible model input parameter space both locally or globally. Global sensitivity analyses (Saltelli et al., 2008) map the importance of the parameters and their interactions for model 
output in a systematic way across the entire input parameter space. This procedure requires thousands of model evaluations, which can easily be computed in parallel on a desktop computer, computation server or High-Performance Computation (HPC) cluster. Even more simulations are needed when Bayesian calibration or inverse modelling techniques are applied. These techniques, although of limited potential for parallelisation, efficiently sample the input parameter space using Markov chain Monte Carlo (MCMC) algorithms in search of the input parameter distributions most likely to produce an observed output. Compared to other calibration techniques, they offer a framework for quantifying uncertainties in model predictions and parameters within a proper statistical context, and therefore have recently become increasingly popular (Hartig et al., 2012; Oijen et al., 2005).

Implementing parallelisation, sensitivity analysis and inverse modelling techniques into SVAT and other numerical models is tedious. For performance reasons, these models are usually written in low-level programming languages such as Fortran or $\mathrm{C} / \mathrm{C}++$, the implementation of extensions, therefore, requires extensive programming skills and time resources, that practitioners often lack. State-of-the-art parallel computing, sensitivity analysis and inverse calibration techniques, however, are readily available in the $\mathrm{R}$ Language and Environment for Statistical Computing (R Core Team, 2019) via dedicated extension packages. Moreover, $R$ offers various packages that are particularly useful for climate impact assessments, providing algorithms for downscaling climate projection data (Hanel et al., 2017; Iturbide et al., 2019), database connection interfaces (Conway et al., 2017) and advanced graphics, which all help to tap data streams, process model input and output, and analyse simulation results. Thus, interfacing $R$ with SVAT models and other numerical models is highly advantageous, and has been recognised and recently put into practice for a number of numerical models (Bagnara et al., 2019; Coron et al., 2017; Pullens et al., 2017; Wu and Liu, 2012).

A widely-used numerical model that clearly would benefit from an interface to $\mathrm{R}$ because of the mentioned application limitations is the process-based SVAT model LWF-Brook90 (Hammel and Kennel, 2001). LWF-Brook90 is a modified version of the Brook90 hydrological model (Federer 2002; Federer et al. 2003) and simulates daily transpiration, evaporation, and soil water fluxes through a soil profile covered with vegetation by solving Richard's equation. LWF-Brook90 is written in Fortran and is mainly used in combination with an MS Access user interface (UI) for input data management, parameter selection and model execution. The UI certainly is adequate for manual calibrations and forward simulation for one or several sites (in batch mode), and stimulated the use of the model in various studies 
(>300 publications featuring Brook90 and LWF-Brook90 mostly on forest sites). However, the few studies using LWF-Brook90 in computing-intensive applications like sensitivity analysis, inverse calibrations, or large scale simulations so far either involved external control of the LWF-Brook90 command line tool (Groh and Puhlmann, 2013; Schmidt-Walter et al., 2019) being restricted to Windows operating systems, or a complete conversion of the (Brook90) model code to the R language (Luong et al., 2019), presumably at the expense of execution speed.

With the objective of harnessing the vast resources of the $R$ Environment to the LWFBrook90 hydrological model and warrant its platform independent usability, the R-package LWFBrook90R was developed. LWFBrook90R is an advancement of the package brook90r (Schmidt-Walter, 2018) and serves as a flexible and easy-to-use interface between LWF-Brook90 and R. Through this interface, large-scale applications and complex statistical analyses become widely available to the model, and it can be run on any platform. The present study aims at introducing the package by demonstrating its functionality and potential in the context of two case studies.

\subsection{The LWFBrook90R package}

With LWFBrook90R, the LWF-Brook90 hydrological model can be run directly from within R. The package core function runLWFB90 (Figure 1) constructs the model input objects (parameters, soil_nodes, soil_materials, climate, vegetation) from model control options (options.b90), parameters (param.b90), climate (ClimateData) and soil (SoilData) data, and executes LWF-Brook90. After the simulation has terminated, user-selected results are returned together with the model input. The model control options thereby contain basic technical information, e.g. the start and end dates of the simulation, type of radiation input (global radiation or sunshine duration), the temporal resolution of precipitation input, use of precipitation correction functions, and the type of water retention and unsaturated hydraulic conductivity model used (Mualem/van Genuchten or Clapp/Hornberger). Aside from basic simulation settings, the user can select from several sub-models for defining aboveground stand properties and leaf area index (LAI) dynamics, phenology, and vertical root length density distributions. All previously available methods of the original MS Access UI have been included and extended by additional features. Furthermore, ancillary functions help to set up the options and parameter input objects conveniently and to estimate soil hydraulic properties from soil physical data using pedotransfer functions. As an advancement over the previous brook90r package, the LWF-Brook90 Fortran code was embedded directly into 
the package as a dynamic library, which is compiled upon package installation. Compiling from source files makes the LWFBrook90R package fully operational on Windows, macOS and Linux operating systems, and also facilitates the usage on computation servers and HPC clusters.

The core function runLWFB90 can be used for single run simulations, where the water balance of a single site is simulated using a predefined set of input parameters. A standard application would be to run a simulation, analyse the results, change some parameters and rerun the simulation. This highly interactive workflow is supported by the properties of $\mathrm{R}$ as an interpreted language and makes it very easy for new users to get familiar with the results and the influence of single parameters in LWF-Brook90.

Multiple simulations with differing model input can be executed with the multi-run function mrunLWFB90. The function provides a flexible tool to perform multiple simulations that incorporate a given variation of input parameters, soil and climate data, by calling runLWFB90 in a parallelised setting. Such parallel multi-run simulations can be used to run the model for a set of locations or climate scenarios using individual soil, climate and input parameters, as it is a common task in climate impact modelling. Furthermore, the function mrunLWFB 90 can be used for applications where high numbers of model evaluations have to be computed using predefined sets of input parameters, e.g. in sensitivity analysis techniques using Monte Carlo simulations (Saltelli et al., 2008), but also in informal inverse calibrations such as the generalised likelihood uncertainty estimation (GLUE) procedure (Beven and Binley, 1992).

Formal Bayesian calibrations can be carried out by connecting LWFBrook90R to one of the various R-packages offering inverse modelling. The connection can be set up by specifying a likelihood function that links a set of model input parameters to a likelihood measure for producing an observed output, by evaluating the differences between model predictions and independent observed values. As all functions for generating model input from parameters and model control options, the LWF-Brook90 dynamic library itself (Figure 1), and a set of functions for processing model output are available to the user, LWFBrook90R can serve as a toolbox for flexibly specifying the likelihood functions. Such a likelihood function can then be sampled by one of the various MCMC samplers of, e.g., the R-package BayesianTools (Hartig et al., 2019). 


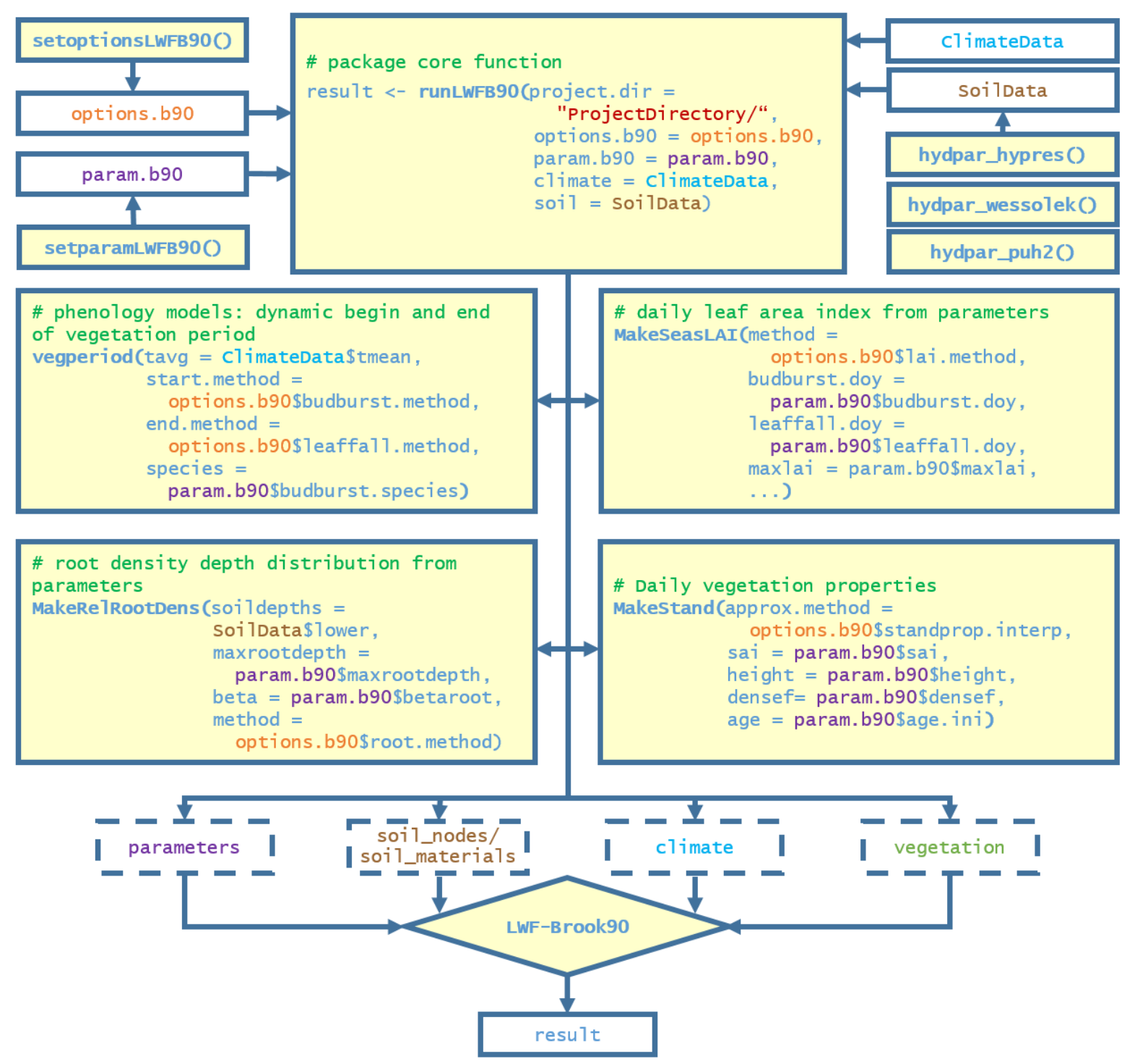

Figure 4-1: The LWFBrook90R workflow. The package core function runLWFB90 constructs the input for LWF-Brook90 from model control options, parameters, soil and climate data, and executes the model. Yellow boxes represent functions available to the user; solid white boxes are data objects that are set up by or returned to the user. Dashed boxes represent model input objects constructed within runLWFB90 and passed to the LWF-Brook90 dynamic library (diamond shaped box).

\subsection{Case studies}

The functionality of the LWFBrook90R R-package is presented through two case studies of different complexity. In the first case study, we depict the standard usage of the package by performing a set of single run simulations representing three different vegetation covers. In the second, more complex case study, we confront the LWF-Brook90 hydrological model with observed data of daily soil water storage. A model calibration experiment is set up comprising the following tasks:

1. a sensitivity analysis; 
2. a Bayesian model calibration and subsequent forward simulation using the calibrated parameter distributions.

All tasks are carried out entirely from within $\mathrm{R}$. The $\mathrm{R}$ code and detailed instructions for each task are provided along with package installation information and the required data sets in the Appendix.

\subsubsection{Case study 1: Single run simulations}

To demonstrate the basic use of the package, three single run simulations were performed using meteorological and soil data measured at the Solling beech long-term ecological research (LTER) site (Fleck et al., 2016; Meesenburg et al., 2016) in central Germany $\left(51^{\circ} 45^{\prime} 41^{\prime \prime} \mathrm{N}, 9^{\circ} 34^{\prime} 41^{\prime \prime} \mathrm{E}\right)$. The R code is available in Appendix B, meteorological and soil datasets are available after loading the package. The three single run simulations represent a temperate deciduous beech forest stand, a temperate evergreen spruce forest stand and a temperate grassland vegetation cover, for which the characteristic parameters (Table 1) were obtained from Federer et al. (1996). The simulations were run for the period 1981-2010, and made use of the option to estimate the dates of budburst when LAI starts to increase following the degree-day approaches described in Menzel (1997; deciduous, evergreen) and Frich et al. (2002; grass), which are available to LWFBrook90R by importing the R-package vegperiod (Nuske, 2017). The end of the vegetation period, i.e. when LAI starts to decline, was estimated using the methods described by von Wilpert (1991) for the forest cover types, and again Frich et al (2002) for the grassland vegetation. The vertical root density distribution was generated using the $\beta$-model (Gale and Grigal, 1987) with parameter values from Jackson et al. (1996). The soil hydraulic parameters were derived from soil physical properties using a pedotransfer function (Puhlmann and von Wilpert, 2012), available through the function hydpar_puh2 (Fig. 1). Each simulation took about 30 seconds to execute, however, all three simulations could also have been run in parallel using the function mrunLWFB90.

Figure 2 shows the mean (1981 to 2010) monthly water fluxes of the three vegetation covers, along with the transpiration deficit as a measure of drought stress. The highest mean evapotranspiration rates (sum of TRAN, IEVP, GEVP; 1981 to 2010) are originating from the evergreen spruce forest $\left(571 \mathrm{~mm} \mathrm{a}^{-1}\right)$, followed by the deciduous beech forest $\left(446 \mathrm{~mm} \mathrm{a}^{-1}\right)$ and the grassland vegetation (391 $\mathrm{mm} \mathrm{a}^{-1}$ ). Due to the permanent foliation of the evergreen forest and grassland, at least small amounts of rain interception evaporation (IEVP) and forest and grassland, at least small amounts of rain interception evaporation (IEVP) and transpiration (TRAN) also occur in winter (Figure 2). Water uptake starts earlier in the year 
Table 4-1: Input parameters for the three vegetation cover types. All other model parameters are set to default values.

\begin{tabular}{|c|c|c|c|c|c|}
\hline Parameter & Unit & Description & $\begin{array}{l}\text { Temp. } \\
\text { evergreen } \\
\text { forest }\end{array}$ & $\begin{array}{l}\text { Temp. } \\
\text { deciduous } \\
\text { forest }\end{array}$ & $\begin{array}{l}\text { Temp. } \\
\text { grassland }\end{array}$ \\
\hline maxlai & $\left(\mathrm{m}^{2} \mathrm{~m}^{-2}\right)$ & Max. LAI in summer & 6 & 6 & 3 \\
\hline winlaifrac & $(-)$ & $\begin{array}{l}\text { Min. LAI in winter as } \\
\text { fraction of maxlai }\end{array}$ & 0.8 & 0 & 0.5 \\
\hline height & (m) & vegetation height & 25 & 25 & 0.5 \\
\hline sai & $\left(\mathrm{m}^{2} \mathrm{~m}^{-2}\right)$ & stem area index & 0.875 & 0.875 & 0 \\
\hline $\operatorname{glmax}$ & $\left(\mathrm{m} \mathrm{s}^{-1}\right)$ & maximum leaf conductance & 0.0053 & 0.0053 & 0.0053 \\
\hline radex & $(-)$ & $\begin{array}{l}\text { radiation extinction } \\
\text { coefficient }\end{array}$ & 0.5 & 0.6 & 0.7 \\
\hline alb & $(-)$ & albedo & 0.14 & 0.18 & 0.2 \\
\hline albsn & $(-)$ & $\begin{array}{l}\text { albedo ground covered with } \\
\text { snow }\end{array}$ & 0.14 & 0.23 & 0.5 \\
\hline maxrlen & $\left(\mathrm{m} \mathrm{m}^{-2}\right)$ & max. fine root length & 3100 & 3500 & 1000 \\
\hline betaroot & $(-)$ & $\begin{array}{l}\text { beta coefficient root } \\
\text { distribution }\end{array}$ & 0.976 & 0.966 & 0.943 \\
\hline maxrootdepth & $(\mathrm{m})$ & max. root depth & -1.2 & -1.4 & -0.8 \\
\hline lwidth & $(\mathrm{m})$ & average leaf width & 0.004 & 0.05 & 0.006 \\
\hline frintlai & $(-)$ & $\begin{array}{l}\text { intercepted fraction of rain } \\
\text { per unit LAI }\end{array}$ & 0.12 & 0.12 & 0.06 \\
\hline frintsai & $(-)$ & $\begin{array}{l}\text { intercepted fraction of rain } \\
\text { per unit SAI }\end{array}$ & 0.14 & 0.25 & 0.06 \\
\hline cintrl & $\left(\mathrm{mm} \mathrm{m}^{-2}\right)$ & $\begin{array}{l}\text { interception storage } \\
\text { capacity for rain per unit } \\
\text { LAI }\end{array}$ & 0.2 & 0.2 & 0.15 \\
\hline cintrs & $\left(\mathrm{mm} \mathrm{m}^{-2}\right)$ & $\begin{array}{l}\text { interception storage } \\
\text { capacity for rain per unit } \\
\text { SAI }\end{array}$ & 0.4 & 0.4 & 0.15 \\
\hline
\end{tabular}

compared to the deciduous forest, where soil evaporation (GEVP) is the main component of evapotranspiration in early spring. The mean seasonal course of simulated soil water potential, an indicator of soil water availability, is shown in Figure 3. During the growing season, evapotranspiration exceeds precipitation, and soil water tension increases. Under forest cover, the reduction in soil water availability during the summer months extends to greater soil depths as compared to the grass cover, due to a deeper rooting system of the trees. The evergreen forest cover shows the deepest soil drought, which is also reflected in the slightly higher, though on average negligible mean transpiration deficit, i.e. the difference between potential and actual transpiration (TDIFF, Figure 2). The simulation results and mean water fluxes generally agree with observations for these vegetation cover types in the Solling area (Bouten and Jansson, 1995; Brumme et al., 2009; Rose et al., 2012). 


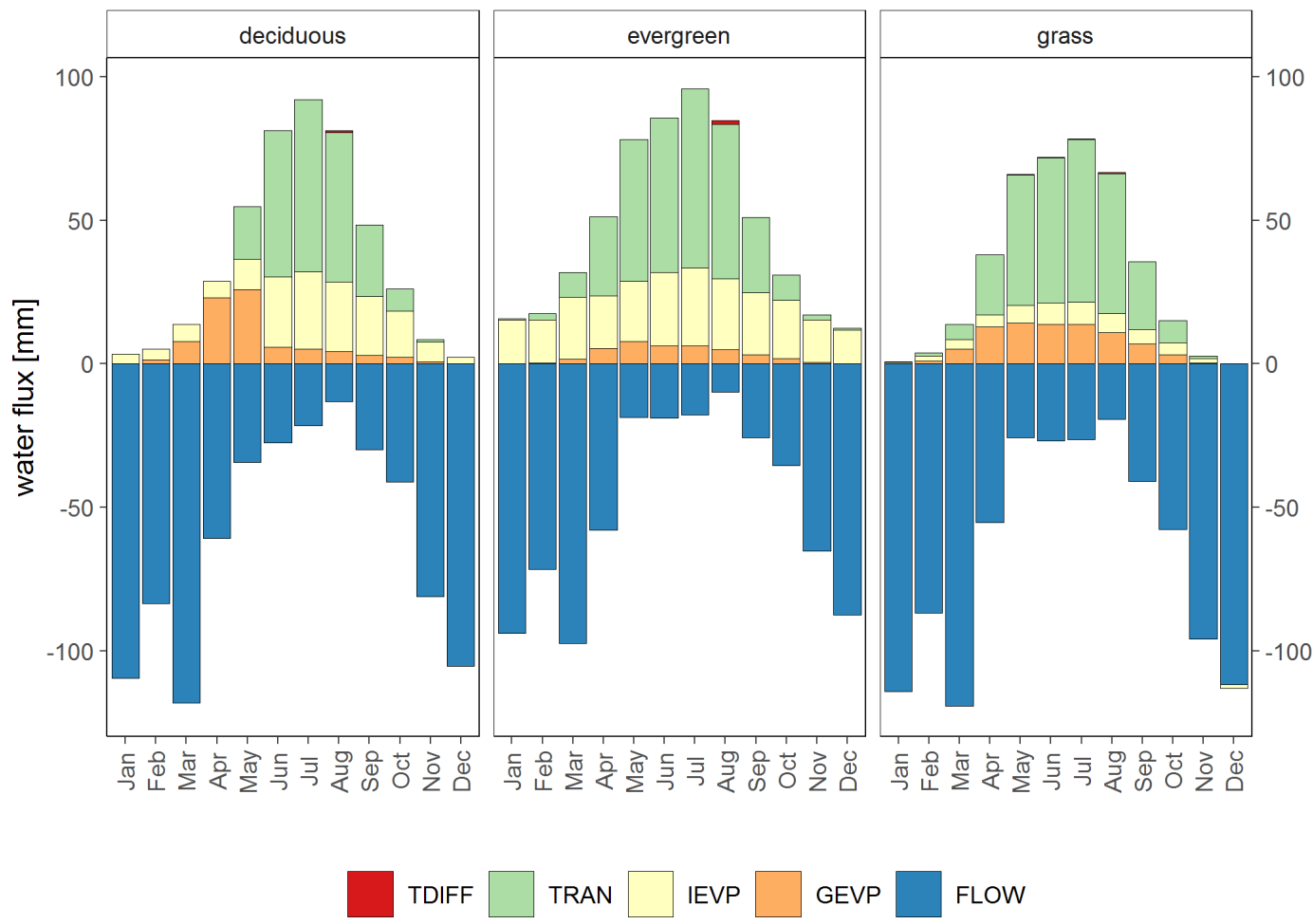

Figure 4-2: Mean monthly seepage water flux (FLOW, displayed as negative values), transpiration (TRAN), rain and snow interception evaporation (IEVP), soil and snow evaporation (GEVP), and transpiration deficit (TDIFF) of the three cover types for the period 1981 to 2010. TDIFF was calculated as potential transpiration minus actual transpiration.

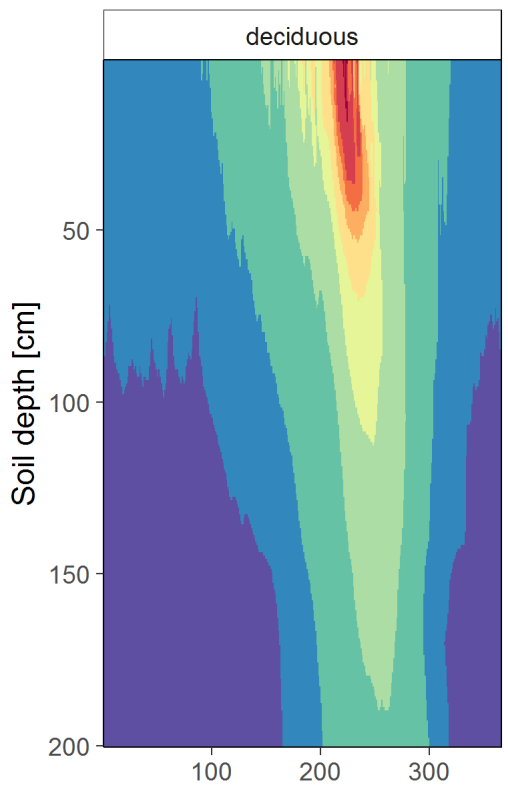

$(0,5]$
PSIMI [kPa]
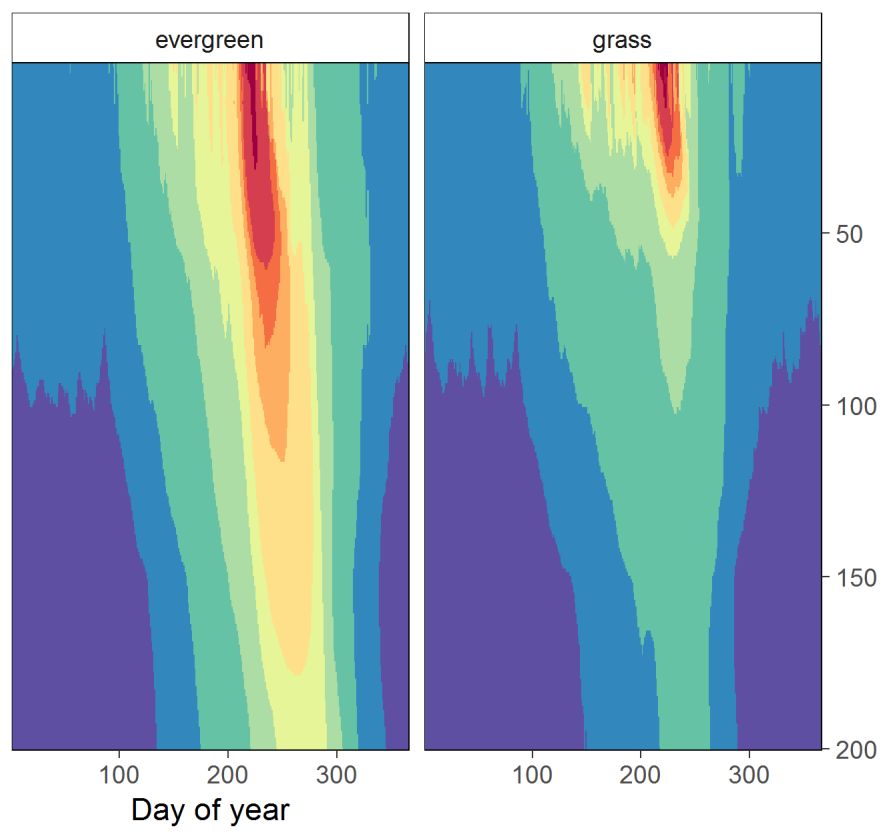

50

100

150
$(60,80]$ $(80,100]$
$(100,150]$
$(150,200]$

Figure 4-3: Mean daily soil water potential (PSIMI) in the period 1981-2010 for the three vegetation cover types. Mean soil water potentials of the soil layers were averaged by day of year, depth-interpolated and classified to discrete values. 


\subsubsection{Case study 2: Sensitivity Analysis and Bayesian Calibration}

In the second case study, we calibrated LWF-Brook90 to daily bulk soil water storage in 0-200 $\mathrm{cm}$ soil depth observed in a poplar (Populus maximowiczii $\times$ P. nigra) short rotation coppice (SRC). The aim was to determine a site-specific model for quantifying water fluxes of the plantation, and their uncertainties. The SRC is located on a deep loess soil over gravel deposits in Kaufering near Munich, Germany (48 $05^{\prime} 13^{\prime}$ 'N, $10^{\circ} 51^{\prime} 39^{\prime \prime}$ E) with a mean annual precipitation of $994 \mathrm{~mm}$, and a mean annual temperature of $8.4^{\circ} \mathrm{C}$ (1981-2010). The SRC was planted in 2008 from cuttings, had an average tree height of $8 \mathrm{~m}$ in 2011 and a closed canopy with an LAI of ca. $6 \mathrm{~m}^{2} \mathrm{~m}^{-2}$. Daily soil water storage was derived by interpolating and integrating volumetric soil water content measured between 2011 and 2012 in 15, 50, 115, 160 and $220 \mathrm{~cm}$ soil depth using FDR probes (10HS, Decagon Devices, Inc.).

We first performed a sensitivity analysis to map parameters that affect model performance with respect to observed soil water storage (Appendix C). Thereafter, the identified parameters where calibrated to observed daily soil water storage in the year 2011 (Appendix D), using the differential evolution Markov chain Monte Carlo algorithm (DEzs, ter Braak and Vrugt, 2008). After calibration, a sample was drawn from the joint posterior parameter distribution and a forward simulation was carried out, to analyse the soil water storage and water fluxes during the calibration period (2011) and a validation period (2012). In order to compare the predicted SRC water fluxes to other land use types, the three vegetation covers from the first case study were additionally evaluated for the Kaufering site, using the calibrated soil parameters.

\subsubsection{Sensitivity analyses}

We used the "Monte Carlo filtering" (MCF) method (Hornberger and Spear, 1981; Saltelli et al., 2008) to map parameters that have a positive effect on model performance. In MCF, a parameter sample is split into 'behavioural' and 'non-behavioural' subsets corresponding to the model output below or above a certain threshold (Pianosi et al., 2016). Due to the independency of the individual simulations, MCF can be computed "embarrassingly parallel", and the speed almost linearly scales with the number of cores deployed. To measure the agreement between simulated and observed bulk soil water storage in 0-200 cm soil depth, we calculated Nash-Sutcliffe efficiency (NSE) and considered all simulations having NSE $\geq 0.8$ as behavioural. The parameter distributions of behavioural simulations were subsequently compared to the parameter distributions of the remaining, non-behavioural simulations and analysed for differences using the two-sample Kolgomorov-Smirnov test. 
Table 4-2: Parameters and their prior ranges selected for sensitivity analysis.

\begin{tabular}{|c|c|c|c|c|c|}
\hline Parameter & Description & Group & Unit & $\begin{array}{l}\text { Prior } \\
\min \end{array}$ & $\begin{array}{l}\text { Prior } \\
\max \end{array}$ \\
\hline budburstdoy & Day number of budburst & Phenology & day of year & 90 & 150 \\
\hline emergedur & Duration of leaf unfolding & Phenology & days & 5 & 30 \\
\hline leaffalldur & Duration of leaffall & Phenology & days & 10 & 50 \\
\hline frintlai & Intercepted fraction of rain per unit LAI & $\begin{array}{l}\text { Interception } \\
\text { evaporation }\end{array}$ & $(-)$ & 0.02 & 0.2 \\
\hline frintsai & Intercepted fraction of rain per unit SAI & $\begin{array}{l}\text { Interception } \\
\text { evaporation }\end{array}$ & $(-)$ & 0.02 & 0.5 \\
\hline cintrl & $\begin{array}{l}\text { Interception storage capacity for rain per } \\
\text { unit LAI }\end{array}$ & $\begin{array}{l}\text { Interception } \\
\text { evaporation }\end{array}$ & $\left(\mathrm{mm} \mathrm{m}^{-2}\right)$ & 0.05 & 0.5 \\
\hline cintrs & $\begin{array}{l}\text { Interception storage capacity for rain per } \\
\text { unit SAI }\end{array}$ & $\begin{array}{l}\text { Interception } \\
\text { evaporation }\end{array}$ & $\left(\mathrm{mm} \mathrm{m}^{-2}\right)$ & 0.05 & 0.5 \\
\hline ilayer & Macropore-assisted infiltration depth & Infiltration & $(-)$ & 1 & 13 \\
\hline infexp & Infiltration exponent & Infiltration & $(-)$ & 0 & 1 \\
\hline glmax & Maximum leaf conductance & $\begin{array}{l}\text { Potential } \\
\text { Transpiration }\end{array}$ & $\left(\mathrm{m} \mathrm{s}^{-1}\right)$ & 0.005 & 0.02 \\
\hline cvpd & $\begin{array}{l}\text { Stomata conductance reduction factor for } \\
\text { high vapor pressure deficit }\end{array}$ & $\begin{array}{l}\text { Potential } \\
\text { Transpiration }\end{array}$ & $(\mathrm{kPa})$ & 0.5 & 3 \\
\hline r5 & $\begin{array}{l}\text { Stomata conductance reduction factor for } \\
\text { low solar radiation }\end{array}$ & $\begin{array}{l}\text { Potential } \\
\text { Transpiration }\end{array}$ & $\left(\mathrm{W} \mathrm{m}^{-2}\right)$ & 50 & 400 \\
\hline $\mathrm{t} 1$ & $\begin{array}{l}\text { Air temperature below which stomata } \\
\text { conductance is reduced }\end{array}$ & $\begin{array}{l}\text { Potential } \\
\text { Transpiration }\end{array}$ & ${ }^{\circ} \mathrm{C}$ & 5 & 15 \\
\hline $\mathrm{t} 2$ & $\begin{array}{l}\text { Air temperature above which stomata } \\
\text { conductance is reduced }\end{array}$ & $\begin{array}{l}\text { Potential } \\
\text { Transpiration }\end{array}$ & ${ }^{\circ} \mathrm{C}$ & 20 & 35 \\
\hline mxkpl & Max. hydraulic plant conductivity & Water supply & $\mathrm{mm} \mathrm{d}^{-1} \mathrm{MPa}^{-1}$ & 1 & 30 \\
\hline fxylem & Fraction of plant resistance in xylem & Water supply & $(-)$ & 0.01 & 0.9 \\
\hline psicr & $\begin{array}{l}\text { Critical leaf water potential at which } \\
\text { stomates close }\end{array}$ & Water supply & (Mpa) & -4 & -0.5 \\
\hline alb & Albedo & Meteorology & $(-)$ & 0.1 & 0.3 \\
\hline radex & Radiation extinction coefficient & Meteorology & $(-)$ & 0.4 & 0.7 \\
\hline maxrootdepth & Max. rooting depth & Water uptake & $\mathrm{m}$ & -2 & -1.2 \\
\hline betaroot & Vertical root distribution $\beta$-coefficient & Water uptake & $(-)$ & 0.9 & -0.999 \\
\hline rssa & $\begin{array}{l}\text { Soil evaporation resistance at field } \\
\text { capacity }\end{array}$ & Soil evaporation & $\left(\mathrm{s} \mathrm{m}^{-1}\right)$ & 1 & 1500 \\
\hline sc_ths & Scaling factor for soil porosity & $\begin{array}{l}\text { Soil hydraulic } \\
\text { properties }\end{array}$ & $(-)$ & 0.75 & 1.25 \\
\hline sc_ksat & $\begin{array}{l}\text { Scaling factor for saturated hydraulic } \\
\text { conductivity }\end{array}$ & $\begin{array}{l}\text { Soil hydraulic } \\
\text { properties }\end{array}$ & $(-)$ & -0.5 & 0.5 \\
\hline
\end{tabular}

We analysed 24 model parameters for their impact on model performance (Table 2). The parameters included variables affecting potential transpiration, water uptake, interception evaporation, soil hydraulic properties and phenology. The parameter sample $(\mathrm{N}=30,000)$ was generated from random uniform distributions, where the variation ranges of most parameters (Appendix C) were derived from the literature (Federer, 2002; Federer et al., 2003; Groh and Puhlmann, 2013), if possible (Table 2). For the soil porosity and saturated conductivity parameters of the single soil layers' hydraulic properties, we used scaling factors to vary the values of all soil layers simultaneously. For the layers' porosities we defined a variation range of $\pm 25 \%$ around the initial value, the layers' saturated hydraulic conductivities were varied on 
a logarithmic scale of base 10 by \pm 0.5 magnitudes. The initial soil hydraulic parameters were derived from the soil layers' physical properties (Puhlmann and von Wilpert, 2012). The 30,000 model evaluations were run with the function mrunLWFB90 on a computation server using 15 processors in parallel, which took less than 4 hours to execute, but could also have been run overnight on a desktop computer using three cores. The code and detailed instructions are provided in Appendix $\mathrm{C}$ and additionally include a visualisation of the behavioural parameter distributions and model performance compared to observations.

Out of the 30,000 random parameter samples, 244 were classified as behavioural (NSE $\geq$ 0.8) with respect to observed soil water storage. The results from the Kolgomorov-Smirnov test are presented in Figure 4, with the test statistic $D_{\max }$ referring to the maximum distance between the empirical cumulative distribution functions (ECDFs) of the 244 behavioural parameter sets and the non-behavioural sets.

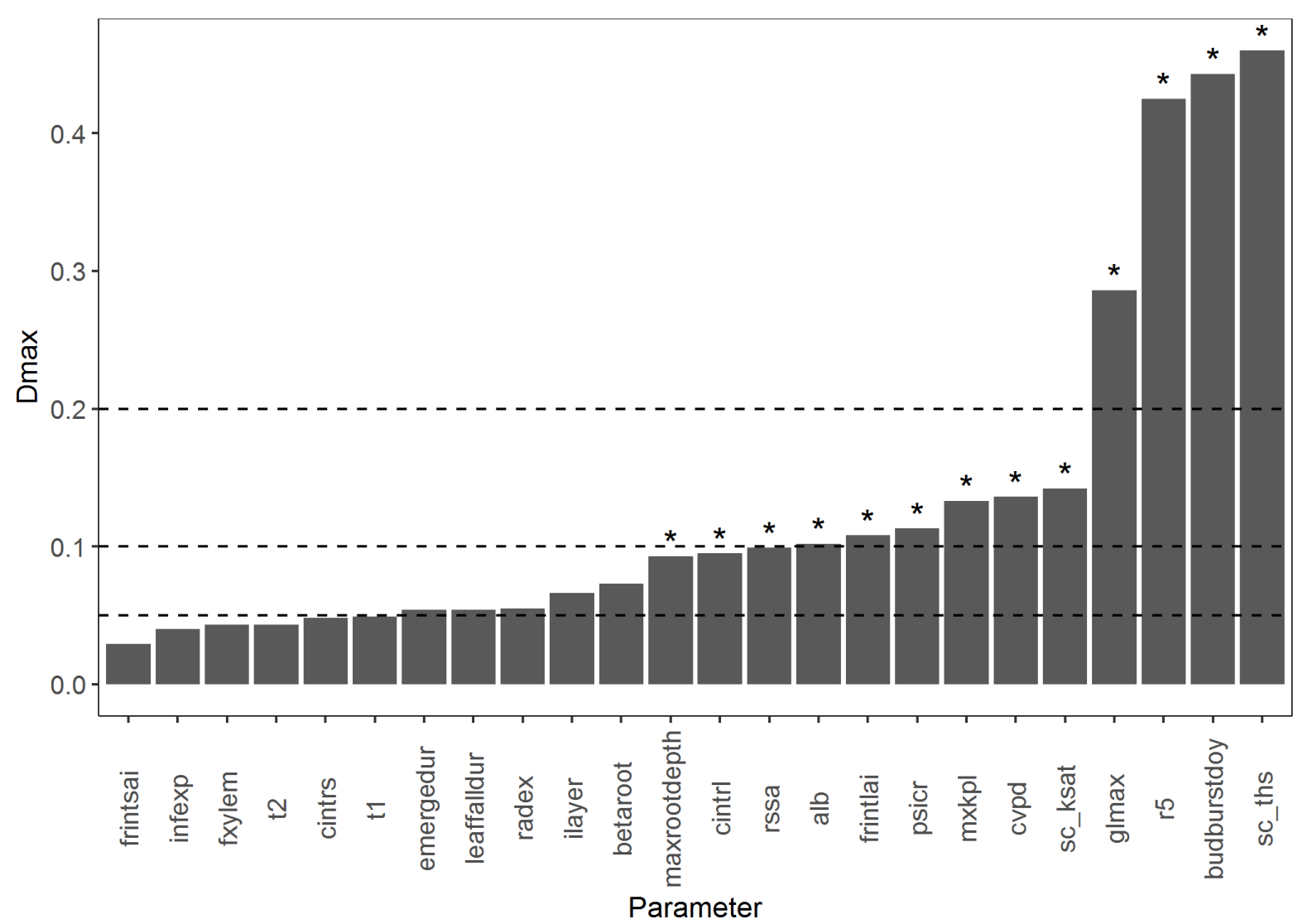

Figure 4-4 Maximum difference $D_{\max }$ between the ECDFs of parameter values resulting in behavioural (NSE $\left.\geq 0.8\right)$ and non-behavioural simulations. Reference lines are set according to the sensitivity classification after Harlin and Kung (1992): $D_{\max } \geq 0.2$ = highly sensitive; $0.1 \leq D_{\max }<0.2=$ moderately sensitive; $D_{\max }<0.1=$ insensitive; asterisks: significant differences between behavioural and non-behavioral parameter distributions ( $\alpha \leq 0.05$, two-sample Kolgomorov-Smirnov test). 
Most important (classified as 'highly sensitive', Harlin and Kung, 1992, Figure 4) for realising model fits in the behavioural model region $(N S E \geq 0.8$ for bulk soil water storage in 0-200 cm soil depth) is the scaling factor for the soil layers' individual porosity ( $s c_{-} t h s$ ), followed by the day number when LAI starts to increase (budburstdoy), and the maximum leaf conductance (glmax) and its reduction factor for low solar radiation ( $r 5)$. These parameters define the vegetation's timing and level of water demand (budburstdoy, glmax, r5), and water storage capacity of the soil profile ( $s c_{-}$ths $)$. Parameters of moderate $(0.1 \leq$ $\left.D_{\max }<0.2\right)$ or low $\left(D_{\max }<0.1\right)$, but significant importance for model fit (Figure 4) can roughly be grouped into factors influencing water supply to the soil (interception parameters frintlai and cintrl), water movement through and out of the soil (sc_ksat), available energy $(a l b)$, and leaf water supply and root water uptake (mxkpl, psicr, maxrootdepth).

The general ranking of parameters we found is in accordance with Federer et al. (2003), who indicate that apart from climatic conditions, highest impacts on annual evapotranspiration result from the vegetation cover type and the available soil water capacity. In our analysis, these two factors are represented by the parameters affecting water demand, total soil water storage capacity and rooting depth. However, the ranking of input parameter importance (Figure 4) only partly agrees with the findings of the so far single sensitivity study of LWF-Brook90 model performance (Groh and Puhlmann, 2013). In accordance with Groh and Puhlmann (2013), we identified the porosity parameter to be the most important parameter for the model fit. However, the other parameters we found to be highly important (budburstdoy, r5) were not tested in their study or only indicated medium importance (glmax). In contrast to our results, the parameter controlling the soil depth of macropore-assisted infiltration of water (ilayer) was of high importance for their model fit, which might be due to the depth-specific measurements of soil water status used as reference data. Such reference data conceivably are more sensitive to the variation of vertical water movement through the soil than the bulk soil water storage we used.

\subsubsection{Bayesian calibration}

Based on the sensitivity analysis, we selected 13 parameters that were significantly important for achieving a high model performance (Figure 4). Additionally, we included ilayer in the calibration, because it was previously reported to have a high importance (Groh and Puhlmann, 2013), and might affect model performance over interactions with other parameters. The $\beta$-parameter of the relative root density depth distribution (betaroot) was also selected as it was correlated with the scaling factor for saturated hydraulic conductivity in the behavioural simulations. 
For the full Bayesian calibration with 15 parameters (Appendix D), we used the same prior ranges as in the sensitivity analysis (Table 2). We specified a Gaussian likelihood function to calculate the log likelihood of a simulation given an observation and standard deviation at each calibration step. We ran the LWF-Brook90 model from 2010 to 2011, but calculated the likelihood based on simulated and observed soil water storage in the year 2011 only. The joint posteriori parameter distribution was estimated using the DEzs algorithm available through the R-package BayesianTools (Hartig et al., 2019). The total execution time for three parallel chains with three sub-chains, running in total for 300,000 iterations, was 70.5 hours (Appendix D).

The calibration for the poplar SRC was successful and converged at a Gelman-Rubin point scale reduction factor of 1.11, with the posterior distribution being reduced over the prior parameter ranges on average by $70 \%$ (26-99\%, see reduction in Table 3$)$. The reduction is a measure of the width of the posterior parameter distributions (Figure 5), and roughly depicts the identifiability of the parameters. All parameters, except for ilayer, psicr, maxrootdepth and rssa, are well defined, however, the posterior distributions of glmax, cvpd and $a l b$ include the edges of their prior distributions. The porosity scaling factor $\left(s c_{-} t h s\right)$ is defined best, with very narrow confidence bounds around 0.928 (Table 3 ). This corresponds to a soil porosity of $723 \mathrm{~mm}$, which is $55 \mathrm{~mm}$ lower than the initial soil porosity derived by the pedotransfer function.

Table 4-3: Posterior parameter distribution statistics. MAP is the Maximum A-Posteriori probability parameter estimate. Reduction is posterior range over prior range $\left(R=\frac{\left(P_{97.5 \%}-P_{2.75 \%}\right)}{(\text { prior max }- \text { prior } \min )}\right)$.

\begin{tabular}{lcrrrrr}
\multicolumn{1}{c}{ Parameter } & Unit & \multicolumn{1}{c}{$2.50 \%$} & \multicolumn{1}{c}{ Median } & \multicolumn{1}{c}{$97.50 \%$} & Reduction & \multicolumn{1}{c}{ MAP } \\
\hline budburstdoy & day of year & 101.182 & 103.376 & 104.928 & $94 \%$ & 104 \\
frintlai & $(-)$ & 0.031 & 0.058 & 0.073 & $77 \%$ & 0.056 \\
cintrl & $\left(\mathrm{mm} \mathrm{m}^{-2}\right)$ & 0.351 & 0.463 & 0.498 & $67 \%$ & 0.464 \\
ilayer & $(-)$ & 1.110 & 3.778 & 9.266 & $32 \%$ & 1.585 \\
glmax & $\left(\mathrm{m} \mathrm{s}^{-1}\right)$ & 0.016 & 0.019 & 0.020 & $73 \%$ & 0.018 \\
cvpd & $\left(\mathrm{kPa}^{2}\right.$ & 2.351 & 2.866 & 2.995 & $74 \%$ & 2.882 \\
r5 & $\left(\mathrm{kPa}^{-}\right.$ & 299.366 & 348.690 & 383.107 & $76 \%$ & 350.174 \\
mxkpl & $\left(\mathrm{W} \mathrm{m}{ }^{-2}\right)$ & 3.418 & 5.267 & 10.098 & $77 \%$ & 4.166 \\
psicr & $(\mathrm{Mpa})$ & -3.912 & -2.669 & -1.401 & $28 \%$ & -3.262 \\
alb & $(-)$ & 0.100 & 0.110 & 0.147 & $76 \%$ & 0.102 \\
maxrootdepth & $\mathrm{m}$ & -1.994 & -1.887 & -1.577 & $48 \%$ & -1.864 \\
betaroot & $(-)$ & 0.979 & 0.981 & 0.982 & $97 \%$ & 0.98 \\
rssa & $\left(\mathrm{s} \mathrm{m}^{-1}\right)$ & 744.348 & 1231.537 & 1484.586 & $51 \%$ & 1295.93 \\
sc_ths & $(-)$ & 0.925 & 0.927 & 0.930 & $99 \%$ & 0.928 \\
sc ksat & $(-)$ & -0.358 & -0.318 & -0.277 & $92 \%$ & -0.304 \\
\hline
\end{tabular}



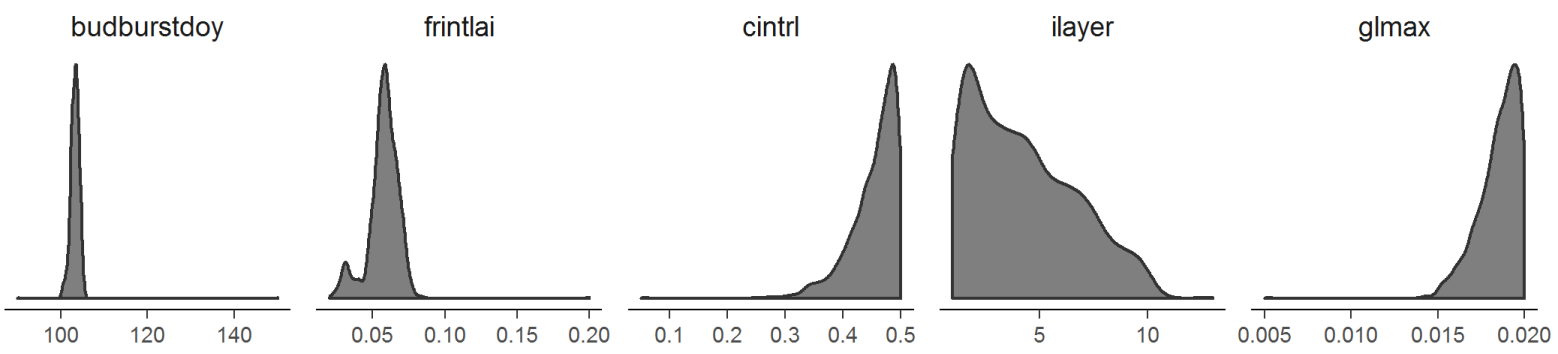

cvpd

r5

mxkpl

psicr

alb
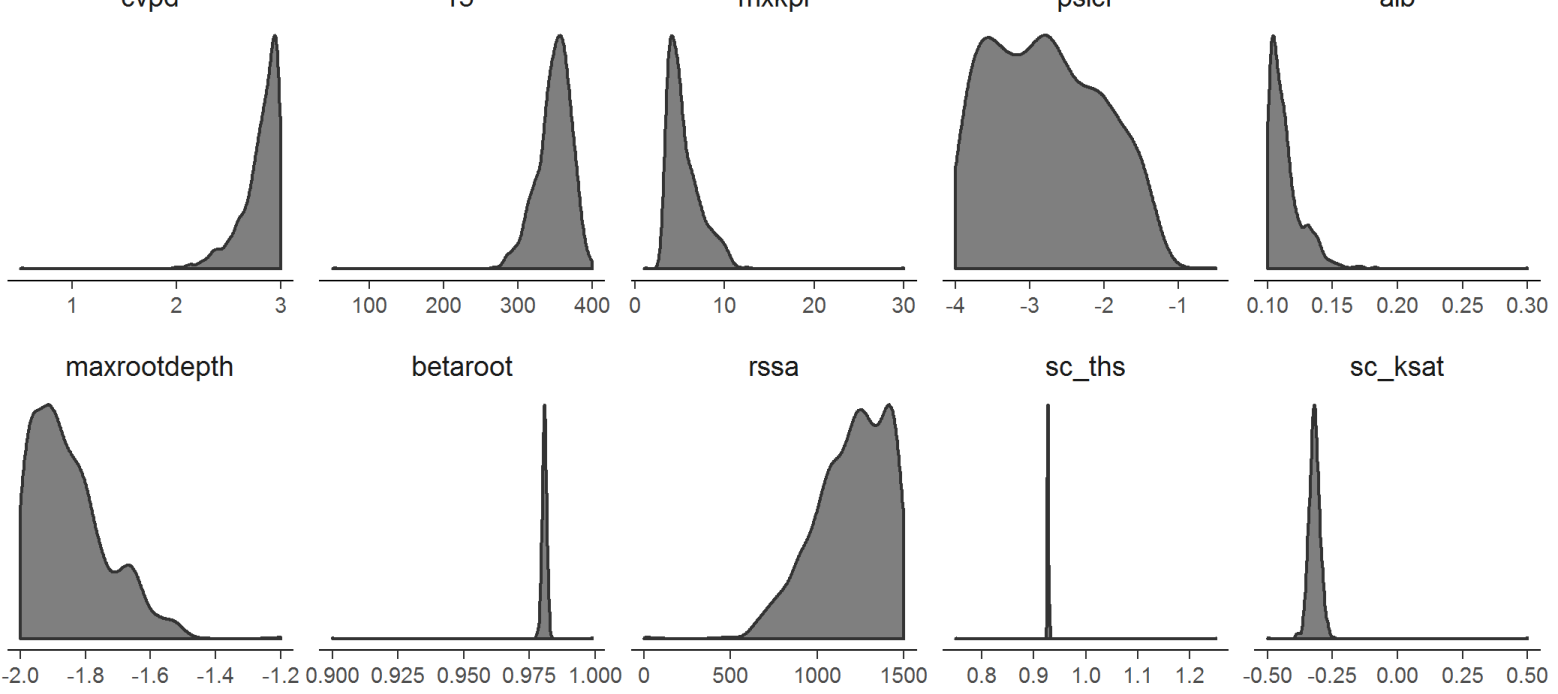

Figure 4-5: Posterior parameter density distributions.

The inverse calibration provided an almost perfect model fit for the calibration period in 2011 (Figure 6 a). The model captured the temporal variation of soil water storage very well $(\mathrm{NSE}=0.98)$, and the mean absolute soil water storage error was below $3 \mathrm{~mm}$. During most of the growing season in 2011 (April-September), soil water storage was above $600 \mathrm{~mm}$, suggesting ample water supply, except for a short period at the end of August, when a small transpiration deficit accumulated (Figure $6 \mathrm{~b}$ ). The confidence interval of the simulated water storage is narrow and only visible during the rewetting phase at the end of 2011. Accordingly, the uncertainties in evapotranspiration water fluxes and deep percolation are low (Figure $6 \mathrm{~b}$, Table 4).

Compared to the calibration period, the validation period (2012, Figure 6 a) was not well represented by the model $(\mathrm{NSE}=0.52)$. On average, bulk soil water storage was underestimated by $20 \mathrm{~mm}$ due to a systematic error affecting the depletion of soil water storage during the vegetation period. While the observations suggest a deceleration in water uptake when soil water storage fell below $580 \mathrm{~mm}$ in July 2012, the simulated water uptake remained high, leading to a maximum absolute deviation of more than $60 \mathrm{~mm}$ in August that persisted until the end of the validation period. 

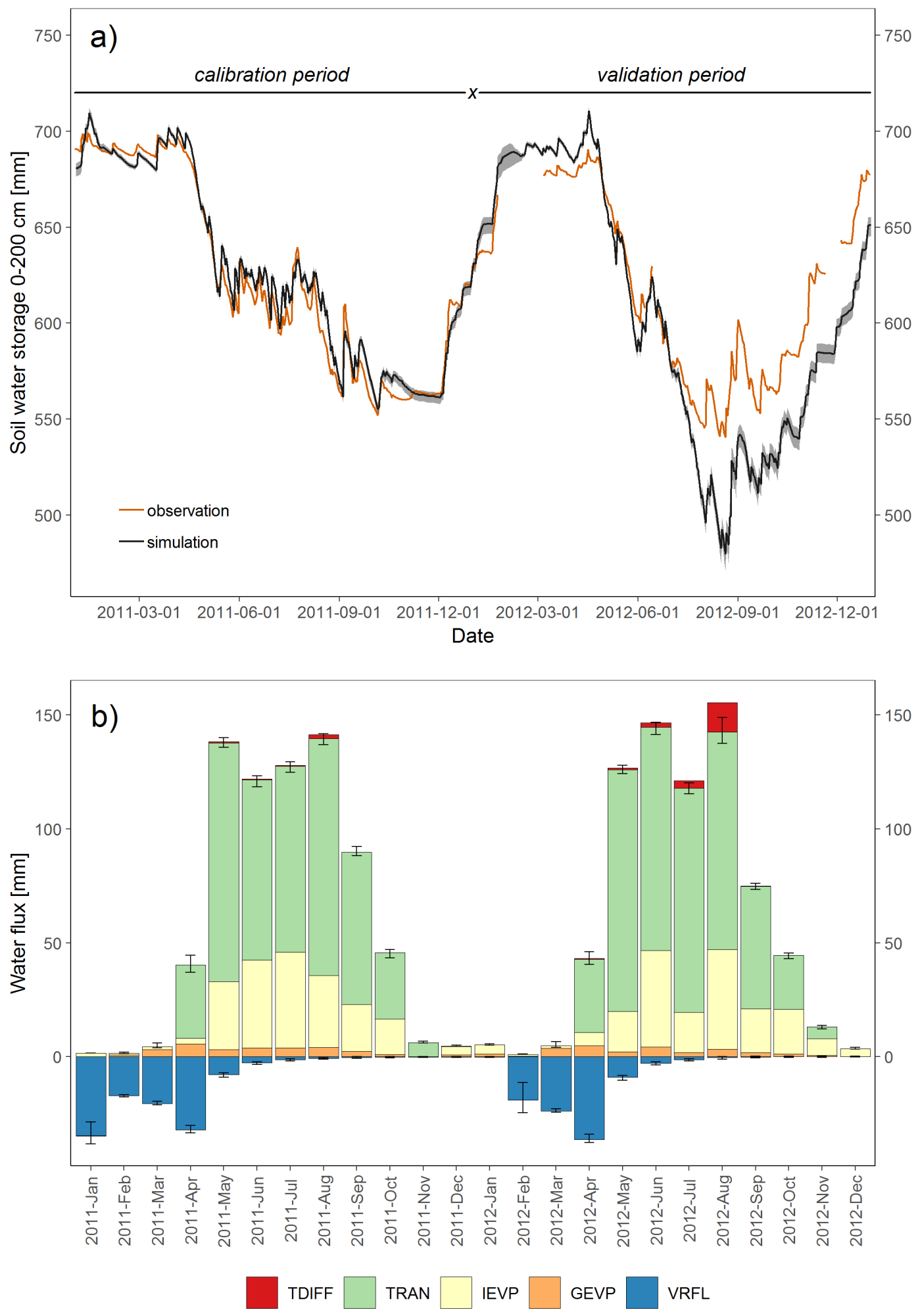

Figure 4-6: Calibration results for the poplar short rotation coppice. a) Comparison of observed and daily mean simulated soil water storage $(n=1000$, uncertainty bounds: 95\% confidence interval). b) Mean monthly water fluxes. Error bars denote $95 \%$ confidence intervals of total evapotranspiration (GEVP+IEVP+TRAN) and vertical water flux in $200 \mathrm{~cm}$ soil depth (VRFL). 
Table 4-4: Predicted annual water fluxes (in $\mathrm{mm} \mathrm{a}^{-1} \pm$ std. dev.) for the Poplar SRC and the three vegetation covers (Table 1) at the Kaufering site.

\begin{tabular}{|c|c|c|c|c|c|c|c|}
\hline & Year & $\begin{array}{c}\text { Evapo- } \\
\text { transpiration }\end{array}$ & Transpiration & $\begin{array}{c}\text { Transpiration } \\
\text { deficit }\end{array}$ & $\begin{array}{l}\text { Interception } \\
\text { evaporation }\end{array}$ & $\begin{array}{c}\text { Ground } \\
\text { evaporation. }\end{array}$ & $\begin{array}{c}\text { Deep } \\
\text { percolation }\end{array}$ \\
\hline \multirow{2}{*}{ Poplar SRC } & 2011 & $721 \pm 5.2$ & $510 \pm 14.8$ & $3.4 \pm 2.0$ & $187 \pm 17.1$ & $29 \pm 4.8$ & $117 \pm 3.5$ \\
\hline & 2012 & $721 \pm 6.0$ & $517 \pm 14.5$ & $19.5 \pm 5.7$ & $182 \pm 15.4$ & $26 \pm 4.4$ & $92 \pm 4.4$ \\
\hline \multirow{2}{*}{$\begin{array}{l}\text { Temp. } \\
\text { evergreen } \\
\text { forest }\end{array}$} & 2011 & 910 & 513 & 0.5 & 302 & 95 & 10 \\
\hline & 2012 & 874 & 452 & 63.0 & 347 & 75 & 4 \\
\hline \multirow{2}{*}{$\begin{array}{l}\text { Temp. } \\
\text { deciduous } \\
\text { forest }\end{array}$} & 2011 & 718 & 365 & 0.3 & 216 & 137 & 114 \\
\hline & 2012 & 729 & 370 & 8.1 & 231 & 129 & 124 \\
\hline \multirow{2}{*}{$\begin{array}{l}\text { Temp. } \\
\text { grassland }\end{array}$} & 2011 & 638 & 409 & 2.9 & 86 & 144 & 164 \\
\hline & 2012 & 633 & 403 & 3.4 & 103 & 127 & 210 \\
\hline
\end{tabular}

The simulated water fluxes and transpiration deficit for the SRC in 2012 (Figure $6 \mathrm{~b}$, Table 4) seem to be unreliable, due to the negative bias in soil water storage. Evapotranspiration fluxes in 2012 probably were overestimated, deep percolation and transpiration deficit were underestimated. The simulation results from 2011 however provide reliable estimates of the water fluxes for the poplar SRC in Kaufering. The simulated sum of transpiration during the growing season $2011(468 \mathrm{~mm})$ thereby equalled measured transpiration reported for a poplar SRC at a site with similar soil properties and climate conditions (Petzold et al., 2011), but was markedly higher than evapotranspiration measured on a site with lower annual precipitation (Schmidt-Walter et al., 2014). Annual transpiration $(510 \mathrm{~mm}$ ) also corresponded to the values reported by Hall $(1998,1996)$ and was higher than grassland and deciduous forest transpiration (Table 4). Annual transpiration roughly amounted to transpiration of the spruce forest cover type that, however, showed the highest annual evapotranspiration $(910 \mathrm{~mm})$, due to largely increased interception evaporation. Evapotranspiration from the poplar SRC was similar to the deciduous forest that, however, had higher interception and soil evaporation. On an annual timescale, simulated evapotranspiration (Table 4) was slightly higher than reference evaporation $\left(\mathrm{ET}_{0}=718 \mathrm{~mm}\right)$ of a well-watered grass surface (Allen et al., 1998), and exceeded $\mathrm{ET}_{0}$ during the months of the growing season by $22-34 \%$. This places our poplar SRC at the upper range of the SRC water use spectrum (cf. Fischer et al., 2018, 2013), and might point to the magnitude of SRC water use that can be realised when water availability is high.

The biased residuals during the validation period indicate overfitting and underrepresented observations in the calibration dataset. In our case, the observed soil water storage in the calibration period 2011 did not cover the lower values of the validation period 2012 and observed deceleration of water uptake (Figure 6 a). Particularly the reduction in water uptake 
in periods of limited water supply could, similar to Baumgarten et al. (2014), could not be represented to a satisfactory degree by the calibrated model. The observed deceleration of water uptake might indicate a drought stress reaction of the trees to decreased soil water availability. For a reliable estimate of drought stress, it is therefore of crucial importance to include periods of limited water supply in the calibration dataset.

Under-representation of conditions can often be resolved by prolonging the calibration period to improve coverage. For the SRC at Kaufering, swapping calibration and validation datasets would probably improve the definition of the water supply parameters psicr and maxrootdepth in the posterior distribution (Figure 5), and provide a more pronounced response of water uptake to limited soil water availability. However, the behaviour of the poplar SRC when water supply is ample, as in the year 2011, might in turn be represented less well. A promising complement to the use of the 2012 soil water storage dataset in model calibration could be the incorporation of additional observational datasets, to further train the model on simulated interception evaporation or transpiration.

Incorporating transpiration or rain interception data were beyond the scope of this preliminary case study. Nonetheless, we may speculate here that the benefits of using in particular daily transpiration might be twofold for the prediction in this example. First, the instant response of daily transpiration to actual meteorological conditions might provide a better definition of model parameters affecting potential transpiration (i.e. glmax, $c v p d, r 5$ ), than a change in bulk soil water storage alone. Especially glmax and cvpd were calibrated to very high values (Table 3) compared to model defaults (Table 1), and touched the upper borders of their prior ranges. Potential transpiration therefore was very high and not efficiently reduced at high vapour pressure deficits. Similarly, water uptake parameters psicr and maxrootdepth were not well defined in the calibration, which potentially imposed little restriction to root water uptake, contributing to too high water uptake at low soil water availability. A better definition of these four parameters through combining soil water storage and transpiration observations might therefore produce a more distinct response of water uptake to actual meteorological conditions and soil water availability. Consequently, uncertainties in transpiration and soil water uptake would decrease, potentially offering the second advantage of an additional transpiration dataset: reduced uncertainties in either simulated transpiration or interception evaporation would simultaneously decrease uncertainties in the respectively other flux, as these fluxes are tightly correlated in the simulations $(\mathrm{r}=-0.95)$, as reflected in increased standard deviations of transpiration and interception over evapotranspiration (Table 4). 


\subsection{Conclusion}

The presented LWFBrook90R package was developed to make the vast resources of $R$ available to the LWF-Brook90 hydrological model. Two case studies demonstrated the potential of the package to run LWF-Brook90 with a minimum amount of coding, to allow for parallel simulations, and to connect to advanced statistical tools, such as the DEzs calibration algorithm applied here. The latter demonstrated the potential of state-of-the-art Bayesian calibrations for predicting soil water availability and water fluxes with LWF-Brook90, but also highlighted the increased demands placed on observational data by such applications, which in our case study resulted in overfitting due to insufficient coverage in the calibration dataset. Large amounts of heterogeneous, harmonized high quality observational data are, however, increasingly becoming available through long-term ecosystem monitoring programmes covering a wide range of climatic and soil conditions. Such data can well be used to train process-based models like LWF-Brook90 models for climate impact and risk assessments.

With a broad data basis in the one hand, and the appropriate tools in the other, a gap often exists in combining a model and the various data streams. With our $\mathrm{R}$ package, we attempt to fill this gap for LWF-Brook90, and enable a better integration of this particular model with data. A better model data integration, and the access to advanced statistical tools provides new opportunities for LWF-Brook90 to systematically assimilate observations into robust and reliable predictions of water fluxes and drought stress (Niu et al., 2014). Bayesian modelling tools provide a statistical framework for separating the prediction uncertainty into uncertainties in parameters, observations and model structure. Accordingly, these tools offer starting points to improve the predictive capacity of LWF-Brook90 in climate impact and risk assessments, e.g. by narrowing down prediction spans through combining heterogeneous datasets and additional field measurements to systematically constrain parameter uncertainties (LeBauer et al., 2013), or by identifying shortcomings in the model structure and subsequent improvement of the model.

In addition to providing access to state-of-the-art statistical tools, the ability to run LWFBrook90 directly from within $\mathrm{R}$ fosters scientific reporting and the reproducibility of simulation results through scripting of applications. The high-level core function runLWFB90 facilitates model set up and simulation using only a few commands, and therefore is also well suited for educational purposes and interactive use. The open source availability and platform-independent usability of LWFBrook90R will foster the widespread 
use of LWF-Brook90, and can advance our understanding of soil-vegetation-atmosphere interactions.

\section{References}

Allen, R.G., Pereira, L.S., Raes, D., Smith, M., 1998. Crop evapotranspiration: guidelines for computing crop water requirements (No. 56), FAO Irrigation and drainage papers. FAO, Rome.

Bagnara, M., Silveyra Gonzalez, R., Reifenberg, S., Steinkamp, J., Hickler, T., Werner, C., Dormann, C.F., Hartig, F., 2019. An R package facilitating sensitivity analysis, calibration and forward simulations with the LPJ-GUESS dynamic vegetation model. Environ. Model. Softw. 111, 55-60. https://doi.org/10.1016/j.envsoft.2018.09.004

Baumgarten, M., Weis, W., Kühn, A., May, K., Matyssek, R., 2014. Forest transpirationtargeted through xylem sap flux assessment versus hydrological modeling. Eur. J. For. Res. 133, 677-690. https://doi.org/10.1007/s10342-014-0796-4

Beven, K., Binley, A., 1992. The future of distributed models: Model calibration and uncertainty prediction. Hydrol. Process. 6, 279-298. https://doi.org/10.1002/hyp.3360060305

Bouten, W., Jansson, P.-E., 1995. Water balance of the Solling spruce stand as simulated with various forest-soil-atmosphere models. Ecol. Model., Modelling Water, Carbon and Nutrient Cycles in Forests 83, 245-253. https://doi.org/10.1016/0304-3800(95)001022

Brumme, R., Meesenburg, H., Bredemeier, M., Jacobsen, C., Schönfelder, E., Meiwes, K.J., Eichhorn, J., 2009. Changes in soil solution chemistry, seepage losses, and inputoutput budgets at three beech forests in response to atmospheric depositions, in: Brumme, R., Khanna, P.K. (Eds.), Functioning and Management of European Beech Ecosystems, Ecological Studies. Springer-Verlag, Berlin, pp. 303-336.

Cáceres, M.D., Martínez-Vilalta, J., Coll, L., Llorens, P., Casals, P., Poyatos, R., Pausas, J.G., Brotons, L., 2015. Coupling a water balance model with forest inventory data to predict drought stress: the role of forest structural changes vs. climate changes. Agric. For. Meteorol. 213, 77-90. https://doi.org/10.1016/j.agrformet.2015.06.012

Conway, J., Eddelbuettel, D., Nishiyama, T., Prayaga, S.K., Tiffin, N., 2017. RPostgreSQL: R Interface to the "PostgreSQL" Database System.

Coron, L., Thirel, G., Delaigue, O., Perrin, C., Andréassian, V., 2017. The suite of lumped GR hydrological models in an R package. Environ. Model. Softw. 94, 166-171. https://doi.org/10.1016/j.envsoft.2017.05.002

Engelbrecht, B.M.J., Comita, L.S., Condit, R., Kursar, T.A., Tyree, M.T., Turner, B.L., Hubbell, S.P., 2007. Drought sensitivity shapes species distribution patterns in tropical forests. Nature 447, 80-82. https://doi.org/10.1038/nature05747

Federer, C.A., 2002. BROOK 90: A simulation model for evaporation, soil water, and streamflow. [WWW Document]. URL http://www.ecoshift.net/brook/brook90.htm (accessed 7.22.19).

Federer, C.A., Vörösmarty, C., Fekete, B., 2003. Sensitivity of Annual Evaporation to Soil and Root Properties in Two Models of Contrasting Complexity. J. Hydrometeorol. 4, 1276-1290. https://doi.org/10.1175/1525-7541(2003)004<1276:SOAETS >2.0.CO;2

Federer, C.A., Vörösmarty, C., Fekete, B., 1996. Intercomparison of methods for calculating potential evaporation in regional and global water balance models. Water Resour. Res. 32, 2315-2322. https://doi.org/10.1029/96WR00801

Fischer, M., Trnka, M., Kučera, J., Deckmyn, G., Orság, M., Sedlák, P., Žalud, Z., Ceulemans, R., 2013. Evapotranspiration of a high-density poplar stand in comparison 
with a reference grass cover in the Czech-Moravian Highlands. Agric. For. Meteorol. 181, 43-60. https://doi.org/10.1016/j.agrformet.2013.07.004

Fischer, M., Zenone, T., Trnka, M., Orság, M., Montagnani, L., Ward, E.J., Tripathi, A.M., Hlavinka, P., Seufert, G., Žalud, Z., King, J.S., Ceulemans, R., 2018. Water requirements of short rotation poplar coppice: Experimental and modelling analyses across Europe. Agric. For. Meteorol. 250-251, 343-360. https://doi.org/10.1016/j.agrformet.2017.12.079

Fleck, S., Cools, N., Vos, B.D., Meesenburg, H., Fischer, R., 2016. The Level II aggregated forest soil condition database links soil physicochemical and hydraulic properties with long-term observations of forest condition in Europe. Ann. For. Sci. 1-13. https://doi.org/10.1007/s13595-016-0571-4

Frich, P., Alexander, L.V., Della-Marta, P., Gleason, B., Haylock, M., Tank, A.M.G.K., Peterson, T., 2002. Observed coherent changes in climatic extremes during the second half of the twentieth century. Clim. Res. 19, 193-212. https://doi.org/10.3354/cr019193

Gale, M.R., Grigal, D.F., 1987. Vertical root distributions of northern tree species in relation to successional status. Can. J. For. Res. 17, 829-834. https://doi.org/10.1139/x87-131

Groh, J., Puhlmann, H., 2013. Kalibrierung eines Bodenwasserhaushaltsmodells mit einer kombinierten Zielfunktion für die Optimierung der Wasserretentionskurve. Hydrol. Wasserbewirtsch. 57, 152-163. https://doi.org/10.5675/HyWa_2013,4_1

Hall, R.L., Allen, S.J., Rosier, P.T.W., Hopkins, R., 1998. Transpiration from coppiced poplar and willow measured using sap-flow methods. Agric. For. Meteorol. 90, 275-290.

Hall, R.L., Allen, S.J., Rosier, P.T.W., Smith, D.M., Hodnett, G., Roberts, J.M., Hopkins, R., Davies, H.N., 1996. Hydrological effects of short rotation energy coppice. Final report to ETSU. Institute of Hydrology, Wallingford.

Hammel, K., Kennel, M., 2001. Charakterisierung und Analyse der Wasserverfügbarkeit und des Wasserhaushalts von Waldstandorten in Bayern mit dem Simulationsmodell BROOK90, Forstliche Forschungsberichte München.

Hanel, M., Kožín, R., Heřmanovský, M., Roub, R., 2017. An R package for assessment of statistical downscaling methods for hydrological climate change impact studies. Environ. Model. Softw. 95, 22-28. https://doi.org/10.1016/j.envsoft.2017.03.036

Harlin, J., Kung, C.-S., 1992. Parameter uncertainty and simulation of design floods in Sweden. J. Hydrol. 137, 209-230. https://doi.org/10.1016/0022-1694(92)90057-3

Hartig, F., Dyke, J., Hickler, T., Higgins, S.I., O’Hara, R.B., Scheiter, S., Huth, A., 2012. Connecting dynamic vegetation models to data - an inverse perspective. J. Biogeogr. 39, 2240-2252. https://doi.org/10.1111/j.1365-2699.2012.02745.x

Hartig, F., Minunno, F., Paul, S., 2019. BayesianTools: General-Purpose MCMC and SMC Samplers and Tools for Bayesian Statistics.

Hornberger, G.M., Spear, R., 1981. An Approach to the Preliminary Analysis of Environmental Systems. J Env. Manage U. S. 12:1.

Iturbide, M., Bedia, J., Herrera, S., Baño-Medina, J., Fernández, J., Frías, M.D., Manzanas, R., San-Martín, D., Cimadevilla, E., Cofiño, A.S., Gutiérrez, J.M., 2019. The R-based climate4R open framework for reproducible climate data access and post-processing. Environ. Model. Softw. 111, 42-54. https://doi.org/10.1016/j.envsoft.2018.09.009

Jackson, R.B., Canadell, J., Ehleringer, J.R., Mooney, H.A., Sala, O.E., Schulze, E.D., 1996. A global analysis of root distributions for terrestrial biomes. Oecologia 108, 389-411. https://doi.org/10.1007/BF00333714

Kelly, A.E., Goulden, M.L., 2008. Rapid shifts in plant distribution with recent climate change. Proc. Natl. Acad. Sci. 105, 11823-11826. https://doi.org/10.1073/pnas.0802891105 
LeBauer, D.S., Wang, D., Richter, K.T., Davidson, C.C., Dietze, M.C., 2013. Facilitating feedbacks between field measurements and ecosystem models. Ecol. Monogr. 83, 133-154. https://doi.org/10.1890/12-0137.1

Luong, T.T., Wiemann, S., Lorenz, J., Kronenberg, R., Bernhofer, C., 2019. Soil moisture simulations based on regionalized soil parameters for the Free State of Saxony, in: Geophysical Research Abstracts. Presented at the EGU, Vienna, Austria.

Meesenburg, H., Ahrends, B., Fleck, S., Wagner, M., Fortmann, H., Scheler, B., Klinck, U., Dammann, I., Eichhorn, J., Mindrup, M., Meiwes, K.J., 2016. Long-term changes of ecosystem services at Solling, Germany: Recovery from acidification, but increasing nitrogen saturation? Ecol. Indic., The value of long-term ecosystem research (LTER): Addressing global change ecology using site-based data 65, 103-112. https://doi.org/10.1016/j.ecolind.2015.12.013

Menzel, A., 1997. Phänologie von Waldbäumen unter sich ändernden Klimabedingungen Auswertung der Beobachtungen in den Internationalen Phänologischen Gärten und Möglichkeiten der Modellierung von Phänodaten., Forstliche Forschungsberichte München.

Niu, S., Luo, Y., Dietze, M.C., Keenan, T.F., Shi, Z., Li, J., Iii, F.S.C., 2014. The role of data assimilation in predictive ecology. Ecosphere 5, art65. https://doi.org/10.1890/ES1300273.1

Nuske, R., 2017. vegperiod: Determine Thermal Vegetation Periods. https://doi.org/10.5281/zenodo.1466541

Oijen, M.V., Rougier, J., Smith, R., 2005. Bayesian calibration of process-based forest models: bridging the gap between models and data. Tree Physiol. 25, 915-927. https://doi.org/10.1093/treephys/25.7.915

Petzold, R., Schwärzel, K., Feger, K.-H., 2011. Transpiration of a hybrid poplar plantation in Saxony (Germany) in response to climate and soil conditions. Eur. J. For. Res. 130, 695-706. https://doi.org/10.1007/s10342-010-0459-z

Pianosi, F., Beven, K., Freer, J., Hall, J.W., Rougier, J., Stephenson, D.B., Wagener, T., 2016. Sensitivity analysis of environmental models: A systematic review with practical $\begin{array}{lllll}\text { workflow. } & \text { Environ. }\end{array}$ https://doi.org/10.1016/j.envsoft.2016.02.008

Puhlmann, H., von Wilpert, K., 2012. Pedotransfer functions for water retention and unsaturated hydraulic conductivity of forest soils. J. Plant Nutr. Soil Sci. 175, 221235. https://doi.org/10.1002/jpln.201100139

Pullens, J.W.M., Bagnara, M., Silveyra González, R., Gianelle, D., Sottocornola, M., Heijmans, M.M.P.D., Kiely, G., Hartig, F., 2017. The NUCOMBog R package for simulating vegetation, water, carbon and nitrogen dynamics in peatlands. Ecol. Inform. 40, 35-39. https://doi.org/10.1016/j.ecoinf.2017.05.001

R Core Team, 2019. R: A Language and Environment for Statistical Computing. R Foundation for Statistical Computing, Vienna, Austria.

Rose, L., Coners, H., Leuschner, C., 2012. Effects of fertilization and cutting frequency on the water balance of a temperate grassland. Ecohydrology 5, 64-72. https://doi.org/10.1002/eco.201

Saltelli, A., Ratto, M., Andres, T., Campolongo, F., Cariboni, J., Gatelli, D., Saisana, M., Tarantola, S., 2008. Global Sensitivity Analysis: The Primer. John Wiley \& Sons, Ltd, Chichester, England.

Schmidt-Walter, P., 2018. brook90r. https://doi.org/10.5281/zenodo.1433677

Schmidt-Walter, P., Ahrends, B., Mette, T., Puhlmann, H., Meesenburg, H., 2019. NFIWADS: the water budget, soil moisture, and drought stress indicator database for the German National Forest Inventory (NFI). Ann. For. Sci. 76, 39. https://doi.org/10.1007/s13595-019-0822-2 
Schmidt-Walter, P., Richter, F., Herbst, M., Schuldt, B., Lamersdorf, N.P., 2014. Transpiration and water use strategies of a young and a full-grown short rotation coppice differing in canopy cover and leaf area. Agric. For. Meteorol. 195-196, 165178. https://doi.org/10.1016/j.agrformet.2014.05.006

ter Braak, C.J.F., Vrugt, J.A., 2008. Differential Evolution Markov Chain with snooker updater and fewer chains. Stat. Comput. 18, 435-446. https://doi.org/10.1007/s11222008-9104-9

von Wilpert, K., 1991. Intraannual variation of radial tracheid diameters as monitor of site specific water stress. Dendrochronologia 9, 95-113.

Walko, R.L., Band, L.E., Baron, J., Kittel, T.G.F., Lammers, R., Lee, T.J., Ojima, D., Pielke, R.A., Taylor, C., Tague, C., Tremback, C.J., Vidale, P.L., 2000. Coupled Atmosphere-Biophysics-Hydrology Models for Environmental Modeling. J. Appl. Meteorol. 39, 931-944. https://doi.org/10.1175/15200450(2000)039<0931:CABHMF $>2.0 . \mathrm{CO} ; 2$

$\mathrm{Wu}, \mathrm{Y}$., Liu, S., 2012. Automating calibration, sensitivity and uncertainty analysis of complex models using the R package Flexible Modeling Environment (FME): SWAT as an example. $\quad$ Environ. Model. Softw. 31, 99-109. https://doi.org/10.1016/j.envsoft.2011.11.013 
Chapter 5

Synthesis

Paul Schmidt-Walter 
Considering the main objectives of this dissertation: (1) evaluate the water balance of SRCs with respect to other land use types and reference evaporation, (2) comparing the water use of a young SRC to that of a mature SRC, (3) determination of the water use strategy (isohydric or anisohydric) of several poplar hybrids, and (4) to provide an assessment of the environmental impacts of SRC cultivation in the Fuhrberger Feld with respect to the requirements of groundwater protection, this chapter aims to summarize and to discuss the results of the included studies, with regard to their implications for the development of management strategies for water-efficient and sustainable woody biomass production systems.

\subsection{SRC water use and groundwater recharge}

As outlined in chapter 1.3.2, there is a high variability in the literature on SRC water use, and a high degree of uncertainty regarding the potential water demand of SRCs. As suggested, a large part of the reported variability can be explained by site-specific differences in pedoclimatic conditions, which can also be regarded as the primary reason for the differences in annual evapotranspiration rates determined for the willow SRC in the Fuhrberger Feld (Chapter 2) and the poplar SRC in Kaufering (Chapter 4). While annual E in the Fuhrberger Feld simulated with the Coupmodel amounted to $462 \mathrm{~mm}$ (2010) and $538 \mathrm{~mm}$ (2011, Table 27), E simulated with LWFBrook90R for the Kaufering site (Table 4-4) was $721 \pm 5.2 \mathrm{~mm}$ in the calibration period (2011). Although the comparability of the two studies is limited due to the use of different models, data and modelling approaches to evaluate evapotranspiration and groundwater recharge, the results illustrate that SRC water use is a function of water available from precipitation and soil water resources, which both were higher in Kaufering.

With respect to differences in pedo-climatic conditions, the effect of SRC cultivation on the local water balance has to be related to the land use type which SRC might replace, and other land use types of that area. In the Fuhrberger Feld drinking water sanctuary, this would concern the former arable fields that were abandoned for reasons of groundwater protection, but potentially will be reactivated with SRC woody biomass production systems. For the Kaufering SRC, the water balance results are not discussed with regard to the land use type that SRC might replace (arable crop land), because this is the task of the project that provided the data for this study site. Nevertheless, the data will be used here to discuss if the hypothesis of SRC water use being higher than water use of deciduous forests can be accepted or has to be rejected. 
Over the two years of study, groundwater recharge from the willow SRC W05 in the Fuhrberger Feld on average was $180 \mathrm{~mm} \mathrm{y}^{-1}$, corresponding to a reduction of $40 \%$ compared to the former arable field Ref (305 $\mathrm{mm} \mathrm{y}^{-1}$, Table 2-7). A reduction in groundwater recharge therefore can be expected in the Fuhrberger Feld, if the set-aside areas are reactivated with SRC woody biomass production systems. The reduction was attributed to higher interception evaporation $\left(E_{i}\right)$ and transpiration $\left(E_{t}\right)$ rates of the willow SRC. In both years, $E_{i}$ in W05 amounted to $170 \mathrm{~mm}$, and $\mathrm{E}_{t}$ was $219 \mathrm{~mm}$ and $293 \mathrm{~mm}$ in 2010 and 2011, respectively. These values are comparable to annual $E_{i}$ and $E_{t}$ rates for deciduous forests on similar sites. However, annual $\mathrm{E}$ is lower than $\mathrm{E}$ reported for coniferous pine and spruce forests, that have higher annual $\mathrm{E}_{\mathrm{i}}$ due to their evergreen canopy, that intercepts considerable amounts of rain also outside the growing season (Meesenburg et al., 2014). The results from the W05 plot therefore might suggest that the hypothesis of SRC water use being higher than that of deciduous forests has to be rejected.

However, the process-based simulations also indicated that $\mathrm{E}_{\mathrm{t}}$ of W05 was limited due to the relatively low amount of plant available water of the sandy soils in the Fuhrberger Feld. During the relatively dry summer 2010 , simulated $E_{t}$ even collapsed due to exhausted soil water resources, and typical drought stress symptoms (leaf shedding) were observed in the willow stand. From these findings, it was concluded that the low soil water capacity sets an upper limit for SRC yield in the Fuhrberger Feld, but also provides a safeguard for a minimum groundwater recharge, as the amount of precipitation required to refill the soil water storage after $E_{t}$ ceases in autumn, is low, even when available soil water is completely exhausted during the course of a growing season. Furthermore, it was suggested that the willow stand would have used considerably more water if the site water availability would have been higher, either due to a higher soil water capacity, or a groundwater table within reach of the roots. Under these circumstances, it remains unclear if SRC water use would still be similar to deciduous forests. Our hypothesis therefore cannot be safely rejected, especially as the groundwater level in large parts of the Fuhrberger Feld is high, and the water availability in these areas has to be considered as markedly increased over the water availability at the W05 plot. Consequently, the hypothesis should additionally be tested by evaluating SRC water use at a site, where water availability is not seriously limited.

A perception of the water use of SRCs when water availability is high is provided by the results of the water balance simulations for the Kaufering poplar SRC (Chapter 4). The simulations were trained on observed daily soil water storage in $0-200 \mathrm{~cm}$ soil depths using a Bayesian calibration algorithm that found an almost perfect model fit for the year 2011 (Nash- 
Sutcliffe-efficiency: 0.98). In Kaufering, plant available soil water capacity is about twice the value of the W05 plot in the Fuhrberger Feld, and average precipitation (1981-2010) during the growing season is more than $600 \mathrm{~mm}$. Despite of the high mean annual precipitation (ca. $1000 \mathrm{~mm}$ ), the simulated annual groundwater recharge for the poplar SRC was estimated to be only $100 \mathrm{~mm}$ (Table 4-4). Accordingly, $\mathrm{E}_{\mathrm{t}}$ was estimated to be more than $500 \mathrm{~mm} \mathrm{y}^{-1}$, and roughly double the estimates for the W05 plot in Fuhrberg. These findings confirm the previous presumption from Chapter 2, with the reduction in groundwater recharge being higher, the larger plant available soil water capacity is at a specific site.

To address the question whether SRC water use is higher than the water use of deciduous forests, a parameter set representing the characteristics of deciduous forest stands (Federer et al., 1996) was evaluated at the Kaufering site, in order to determine the water balance of a hypothetical beech forest with LWFBrook90R. Such a direct comparison provides more meaningful results than a comparison to evapotranspiration rates observed in real forest stands, which are often constrained to sites with less favourable growth conditions in terms of soil water availability. Using identical soil and climate data, annual $\mathrm{E}_{\mathrm{t}}$ modelled for beech was almost $150 \mathrm{~mm}$ lower than the values estimated for the poplar SRC (510 $\left.\mathrm{mm} \mathrm{y}^{-1}\right)$. Compared to poplar, $E_{t}$ for beech (2011: $365 \mathrm{~mm}, 2012: 370 \mathrm{~mm}$; Table 4-4) appears low, but corresponds to observations made in a beech forest near Munich (Baumgarten et al., 2014) on a similar, though less deep loess soil, supporting Roberts' hypothesis (1983). While simulated soil evaporation was negligible in the poplar $\operatorname{SRC}\left(\mathrm{E}_{\mathrm{s}}<30 \mathrm{~mm} \mathrm{y}^{-1}\right), \mathrm{E}_{\mathrm{s}}$ made up a considerable part of the annual water balance (ca. $130 \mathrm{~mm} \mathrm{y}^{-1}$ ) of the hypothetical beech forest. This value appears high, as the largest part of annual $E_{\mathrm{s}}$ in beech evaporates early in spring before budburst and subsequent leaf unfolding of the beech canopy. The simulated $\mathrm{E}_{\mathrm{s}}$ in beech therefore can also be interpreted as $E_{t}$ of the understorey vegetation, which in mesic beech forests is developed early in spring, before foliation of the beech canopy. Understorey vegetation was missing in the poplar SRC in Kaufering, where the observations on soil water storage, and the calibrated parameter defining the day of budburst in spring (budburstdoy, Table 4-3) indicated an earlier development of the poplar canopy compared to beech. The discrepancy in $E_{s}$ therefore seems plausible, and in terms of total water use (E) compensated the lower $E_{t}$ rate of beech, so that the differences between the amount of water used by poplar $\left(721 \mathrm{~mm} \mathrm{y}^{-1}\right)$ and deciduous beech $\left(718 \mathrm{~mm} \mathrm{y}^{-1}\right)$ eventually were small (Table 4-4). In conclusion, the hypothesis of SRC water use being higher than water use of deciduous forests cannot be accepted. 


\subsection{Influence of canopy closure and leaf area on SRC evapotranspiration}

The influence of the developmental stage of SRCs was investigated in detail in Chapter 3. There, evapotranspiration of the mature poplar SRC in Großfahner was derived from sap flux and stand precipitation to estimate growing season $\mathrm{E}_{\mathrm{t}}$ and $\mathrm{E}_{\mathrm{i}}$, and opposed to evapotranspiration estimated by the BREB method in the young poplar SRC (P09) in the Fuhrberger Feld. Based on a comparison of crop coefficients, transpiration ratios on rainless days, and canopy conductance under reference meteorological conditions $\left(\mathrm{g}_{\mathrm{c}}{ }^{*}\right)$, growing season E of $380 \mathrm{~mm}$ from P09 was evaluated to not differ substantially from E in Großfahner (445 mm), despite contrasting canopy densities of the two poplar plantations. The lack of disagreement was attributed to a considerable contribution of $E_{s}$ and understorey- $E_{t}$ to $E$ in the young SRC during the first half of the growing season, before canopy closure. These contributing fluxes where assumed to be negligible in the mature SRC, and in the young SRC, additional to their bare presence, seemed to be less well regulated with feedback to evaporative demand than $E_{t}$ of the poplar canopy. After canopy closure at LAI $>3 \mathrm{~m}^{2} \mathrm{~m}^{-2}, \mathrm{E}$ in P09 was dominated by $\mathrm{E}_{\mathrm{t}}$ of the young poplars that, similar to the mature poplar SRC, apparently controlled $\mathrm{E}_{\mathrm{t}}$ efficiently through stomata closure in response to increasing D. Daily mean $\mathrm{g}_{\mathrm{c}}{ }^{*}$ (Figure 3-5) then indicated a slightly lower water demand of the young poplar compared to the mature poplar stand, potentially caused by the lower LAI of the young SRC. However, this slightly lower transpiration potential appeared not to affect overall growing season water use in $\mathrm{P} 09$, because $\mathrm{E}_{\mathrm{s}}$ and understorey- $\mathrm{E}_{\mathrm{t}}$ before canopy closure might even over-compensate reduced $\mathrm{E}_{\mathrm{t}}$ of the young SRC. The hypothesis of young SRCs with a more open canopy using less water than mature SRCs with a closed canopy therefore cannot be accepted.

Nevertheless, a slightly lower water demand of closed canopies with low leaf area might still be possible, as suggested by lower $\mathrm{g}_{\mathrm{c}}{ }^{*}$ of P09 at an LAI of $3.8 \mathrm{~m}^{2} \mathrm{~m}^{-2}$, compared to the high density canopy of the SRC in Großfahner (LAI $=7.4 \mathrm{~m}^{2} \mathrm{~m}^{-2}$ ). This is also indicated by the results from the W05 plot in Fuhrberg, where the willow stand was harvested in early 2011 and subsequently regrew, but leaf and shoot development were considerably delayed compared to the previous year. This probably additionally reduced $\mathrm{E}_{\mathrm{i}}$ compared to the mature stand, as inferred from swapping the observed LAI and stand development between the years in the water balance simulation (Chapter 2), resulting in slightly higher $E_{i}(+25 \mathrm{~mm})$ of the hypothetical non-harvested stand in 2011 compared to the actual stand in it first growing season after harvest. An effect on groundwater recharge however was not evaluated. 


\subsection{Characterisation of water use strategies}

The characterisation of water use strategies for the poplar plantations in Großfahner and the Fuhrberger Feld (Chapter 3), as inferred from the stomata closure reaction to increasing D, indicated a water-saving behaviour for the mature, closed-canopy poplar SRC in Großfahner, which resulted in comparatively low $E_{t}$ rates. According to a simple hydraulic model (Oren et al., 1999), stomatal regulation of transpiration was sufficient to maintain a minimum leaf water potential, and thus indicated isohydric behaviour. The young poplar plantation P09 also displayed an isohydric water use behaviour, but only after canopy closure, when $E_{t}$ was dominating E. While the water use strategy in Großfahner could be unambiguously assigned to the hybrid $J-105$, it was not possible to distinguish between the three poplar hybrids Max 3, Androscoggin and $A F 2$ due to the use of the BREB method instead of sap flux density measurements to determine $\mathrm{E}_{\mathrm{t}}$. However, the BREB method provided the advantage of capturing also $E_{s}$ and understorey- $E_{t}$, to which a more anisohydric water use signal was attributed, which was detected before canopy closure during the first half of the growing season. The hypothesis about the water use behaviour of the investigated poplar hybrids being isohydric therefore can be accepted, but in a strict sense would only apply to the $J-105$ hybrid of the Großfahner plantation, as the $E_{t}$ signals could not be partitioned to individual poplar hybrids at P09 in Fuhrberg.

The J-105 poplar hybrid and the P09 plantation as a whole displayed a conservative, water-saving water use strategy. Due to the lack of anisohydric behaviour, an effect of different water use strategies on SRC water use could not be evaluated, and until recently, there were only hints for an indeed anisohydric behaviour in the literature about field studies on SRC water use. However, observations from a plantation in Belgium (Navarro et al., 2018) now provide an idea of the variation in water demand that could be associated with contrasting water use strategies of different poplar hybrids. In the mentioned study, two poplar hybrids displayed decreasing leaf water potentials with increasing $\mathrm{D}$, while maintaining a high stomatal conductance. This behaviour differed from the isohydric behaviour of the other two investigated hybrids. While $E_{t}$ of the isohydric hybrids was $334 \mathrm{~mm}$ and $350 \mathrm{~mm}$, the anisohydric poplar hybrids transpired as much as $618 \mathrm{~mm}$ and $483 \mathrm{~mm}$ during the course of one growing season.

\subsection{A synoptic evaluation of SRC water use based on ET $_{0}$}

Although SRC water use was assessed to be comparable to water use of deciduous forests, annual evapotranspiration of the Kaufering poplar SRC in 2011 (721 mm) was high, 
reflecting the high water availability at the site. There, E was similar to the evaporation of a grass reference surface with unlimited water supply $\left(\mathrm{K}_{\mathrm{c}}=1.0\right)$, but was higher than the average SRC crop coefficient suggested by Fischer et al. (2018), who state that SRC water use is significantly lower than $\mathrm{ET}_{0}$. Disagreeing, annual $\mathrm{E}_{\mathrm{t}}$ of more than $500 \mathrm{~mm} \mathrm{y}^{-1}$ in Kaufering rather corresponded to values reported by Hall et al. $(1998,1996)$. Moreover, similar results from an SRC of the same poplar hybrid in Saxony (Petzold et al., 2011), with similar soil (loess) and climate conditions must be seen as justification for the reputation of poplars being great water consumers.

With regard to the proposed average $\mathrm{K}_{\mathrm{c}}$ range of $0.8-0.9$, the results from the Kaufering poplar SRC suggest that on many sites, the water demand of SRCs cannot be satisfied from available water resources. This hampers the full exploitation of the SRC yield potential in many regions in Germany. Even in Kaufering, where a deceleration of water uptake was observed that potentially indicated a limited water availability during the relatively dry summer of 2012, the water demand of the poplars might not be fully satisfied in all years. Nevertheless, the water availability at the Kaufering site is high, which is also reflected in a high mean annual dry mass production of $13 \mathrm{Mg} \mathrm{ha}^{-1}$ (M. Zacios, unpublished) during the five years of the first rotation period. Compared to the average production of the W05 plot in the Fuhrberg Feld (5.7 $\left.\mathrm{Mg} \mathrm{y}^{-1}\right)$, which at crop coefficients of 0.7 (2010) and 0.77 (2011) might serve as an example for sites with frequent water shortage, this is more than twice the yield.

Nevertheless, there is indication that the water demand of SRCs differs, and that $\mathrm{K}_{\mathrm{c}}$ values of 0.8-0.9 seem not be caused by limited water availability in all cases. In Kaufering, evapotranspiration was $22-34 \%$ higher than $\mathrm{ET}_{0}$ during the months of the growing season (April-September), that compensated low $\mathrm{E}$ outside the growing season, so that $\mathrm{E}$ was equal to $\mathrm{ET}_{0}$ at an annual timescale. In contrast to this, the other mature poplar SRC located in Großfahner (Chapter 3) displayed lower E, which was attributed to the isohydric water use strategy of the poplar hybrid. As a consequence, $\mathrm{E}$ was comparable to $\mathrm{ET}_{0}$ throughout the growing season (Figure 3-4b), despite the presence of a shallow groundwater level, and no indication of limited water availability from soil water resources that would have severely inhibited transpiration. From April to October, the mean crop coefficient was 0.97, and at an annual timescale probably matched the average range proposed by Fischer et al. (2018).

It remains unclear, if the differences in crop coefficients between Großfahner and Kaufering were caused by contrasting water use behaviours. Nevertheless, an association with plant material appears plausible, as the results from Kaufering, but also the results from the 
already mentioned SRC in Saxony (Petzold et al., 2011) suggest that clones of the Max 1 poplar hybrid are associated with relatively high transpiration rates. While the relatively low transpiration rates and crop coefficients of the poplar hybrid J-105 corresponded to the observations from another plantation of this clone (Fischer et al., 2013), both Max 1 plantations in Saxony and Kaufering displayed high transpiration rates and crop coefficients, which might have been caused by an anisohydric water use behaviour of this particular poplar hybrid. Indication for such behaviour can be seen in the calibrated model parameters from the inverse modelling approach for the poplar SRC in Kaufering (Table 4-3). These point to a very loose stomatal control of transpiration when compared beech parameter set, that had a much lower transpiration. However, it remains to be shown from stand scale transpiration measurements if high $E_{t}$ in Kaufering actually was caused by an anisohydric water use behaviour.

\subsection{Implications for SRC management}

The results from the SRCs in Fuhrberg, Großfahner, and Kaufering showed that SRCs potentially use more water, the more water is available from in-season precipitation and soil water resources, while a certain potential to control evapotranspiration by informed management decisions appears to be available. In general, the absolute extent of a reduction in groundwater recharge is tightly related to the available soil water storage capacity, as SRCs tend to use all water available from in-season precipitation and additionally develop large soil water deficits during the course of a growing season. For a sustainable production of woody biomass using SRCs, considering both yield and potential adverse effects from a high water consumption, it therefore is crucial to take the available water resources into account, when selecting sites for SRC production.

In productive cropland regions, where the soil water capacity often is high, the effects of SRC cultivation on groundwater recharge tend to be larger than on sites with a low available water capacity. To mitigate adverse hydrological effects from SRC cultivation on such sites, it is also worth considering other tree-based land use types such as alley cropping systems (ACS, Tsonkova et al., 2012). In ACS, strips instead of larger coherent areas are cultivated with trees that alternate with arable crops, which potentially reduces total water use at the field scale. In this way, crop production can be combined with the ecological benefits of trees on arable land, enhancing the overall ecological value of an area (Kay et al., 2019), without putting much pressure on food production. 
While "conventional" SRC cultivation on highly productive arable land such as in Kaufering appears unlikely to be realised in a notable scale, a huge potential for biomass production is provided by SRC cultivation on land of lower productivity or marginal arable land. Based on soil quality, recent estimations identified an area of 58.2 Mha of marginal land in Europe (Gerwin et al., 2018), which is potentially available for producing biomass in a sustainable way. In Germany, the estimated area of marginal land amounts to 3.3 Mha, of which large parts have a low soil water storage capacity resulting from a sandy soil texture, or a shallow soil depth. On these sites, the water balance of SRCs will most likely be comparable to that of deciduous forests due to a limited soil water availability, with a correspondingly moderate absolute reduction of groundwater recharge compared to agricultural crops. However, special attention should be given to sites with an increased water availability due to shallow groundwater levels. On such sites, the net reduction in groundwater recharge can be expected to be higher than for other marginal sites. Especially in Northern Germany, large areas of marginal land are influenced by groundwater, and it is there, where the largest SRC plantation in Germany can be found. Nevertheless, there appears to be a certain steering potential for SRC water use, which might be utilized to reduce SRC water use and optimise SRC water management with regard to the individual requirements of a given production site. The efficacy of these determinants, and their potential for increasing groundwater recharge will be discussed in the following paragraphs.

Different from the expectations framed by the $2^{\text {nd }}$ hypothesis, the results from Chapter 3 implied that young SRCs with an open canopy do not use less water than SRCs with a closed canopy, due to increased soil evaporation and understorey transpiration. Management strategies to constrain canopy cover in SRCs therefore do not seem to efficiently reduce total evapotranspiration. However, the results illustrated the importance of weed control in SRCs which are freshly planted or in the regrowth phase after harvest. Frequent mulching of the understorey vegetation thereby would be advantageous over herbicide applications, as this would eliminate understorey- $\mathrm{E}_{\mathrm{t}}$, and simultaneously reduce soil evaporation due to a certain mulch-effect provided by plant residues covering the soil. In this way, groundwater recharge would not be increased, as the results from the investigated SRCs suggest that the trees anyway use most water available from in-season precipitation and soil water resources. Nevertheless, any achieved reduction of understorey- $E_{t}$ and $E_{s}$ will benefit the trees of an SRC with an open canopy and thus the production of woody biomass.

The results from Chapter 3 also indicated that after canopy closure, a young poplar SRC with a low leaf area has a slightly lower canopy conductance than a mature plantation with 
high leaf area. The difference in canopy conductance implies a slightly lower water demand of the young SRC, and $\mathrm{E}_{\mathrm{i}}$ might also be decreased due to a lower water storage capacity of the canopy for rainfall interception. Therefore, a shorter rotation interval of 2-3 years would potentially reduce SRC evapotranspiration, if this would inhibit a plantation from reaching a high leaf area in the range of the plantations in Großfahner or Kaufering (LAI $>6 \mathrm{~m}^{2} \mathrm{~m}^{-2}$ ).

A more determining factor for evapotranspiration that would in fact provide potential to particularly reduce SRC transpiration in an extent potentially affecting groundwater recharge, appears to be the water use behaviour of the plant material used to establish an SRC. Although the plantations for which the water use behaviour could be characterised all showed an isohydric behaviour, and an effect on groundwater recharge therefore could not be proved, recent observations from Belgium (Navarro et al., 2018) indicate that contrasting water use behaviour of different poplar hybrids can result in very large variations of $\mathrm{E}_{\mathrm{t}}$. With the knowledge on the water use strategy of individual poplar and willow hybrids, the plant material can be specifically selected according to the given pedo-climatic site conditions, and potential requirements to avoid adverse hydrological effects from an excessive water consumption. As the water use strategy potentially also influences biomass yields, a specific selection of plant material appears to be a key for the establishment of environmentally sustainable and economically beneficial SRC biomass production systems.

In this context, management decisions concerning the selection of plant material according to their water use behaviour might be made, by considering the following recommendations and relationships:

- For sites, where water supply is ample but negative hydrological effects should be avoided, select plant material with a conservative, water-saving water use strategy to avoid excessive water consumption. The water-saving behaviour of isohydric plant material would particularly be effective in areas with a high water availability, where isohydric plants would potentially develop less pronounced soil water deficits or use less groundwater during the growing season, and therefore provide increased net groundwater recharge rates over anisohydric plant material.

- In areas where water supply is ample and effects from high water consumption can be ignored, anisohydric plant material can well be used, because higher biomass yields can be expected from anisohydric "waterspenders" due to sustained gas exchange rates. 
- Where water supply is less ample, e.g. due to a low plant available soil water capacity, both isohydric and anisohydric hybrids can be used, at different yield and risk potentials. Differences in groundwater recharge between hybrids of contrasting water use strategy would be less pronounced in areas of low soil water availability, but differences in yield might be observed. While water-saving plants potentially display lower yields than anisohydric plant material, an isohydric water use strategy enables the plants to save water reserves during times of ample water supply, from which the plants can benefit in drought periods, during which soil water stress might be postponed or even avoided. In turn, anisohydric hybrids show higher yields as long as water supply is ensured, however, the risk of severe yield declines and even increased tree mortality impends when water supply ceases during rainless periods.

In a changing environment with an increasing frequency of extreme climatic conditions and a potential shift of the precipitation regime from evenly distributed rainfall to more frequent summer droughts, the considerations made above are becoming even more important.

\subsection{An assessment of the effects of SRC cultivation on groundwater quality and quantity in the Fuhrberger Feld}

The production of woody biomass in the Fuhrberger Feld drinking water abstraction area offers an ecologically sustainable way of reactivating set-aside arable land, and can be regarded to not conflict with the requirements of groundwater protection. The results from Chapter 2 nevertheless showed that soils at the Fuhrberger Feld contain high amounts of organic carbon and $\mathrm{N}$, which bear the risk of increased nitrate leaching. Accordingly, deep ploughing prior to SRC planting causes mineralisation pulses, and increased nitrate concentrations of $16.6 \pm 1.6 \mathrm{mg} \mathrm{NO}_{3}-\mathrm{N} \mathrm{L}^{-1}$ were observed in the seepage water of the $\mathrm{P} 09$ plot during the first drainage period after planting, that exceeded the legal threshold for drinking water. However, the concentration peaks decreased to lower levels in the second drainage period and approached the concentrations observed in the former arable field of less than $1 \mathrm{mg} \mathrm{NO}-\mathrm{N} \mathrm{L}^{-1}$. Considering observations from older SRCs planted in 2005 and 1994, it was concluded that in the medium term, nitrate concentrations in seepage water of SRCs in the Fuhrberger Feld will return to the low levels of the set-aside field, as long as the $\mathrm{N}$ uptake potential of the trees is not inhibited. Consequently, the reactivation of set-aside fallow land with the production of woody biomass can be regarded to not impair groundwater quality in 
the Fuhrberger Feld, and moreover, might also reduce the risk of nitrate leaching in the long run, due to $\mathrm{N}$ uptake by the trees and export through harvesting.

However, the water balance simulations for the willow plot W05 and the former arable field indicated that groundwater recharge of the set-aside land in the Fuhrberger Feld will be reduced by $40 \%$, when this land is reactivated with the production of woody biomass. The reduction will potentially be higher in areas with a higher soil water availability. Special attention should therefore be given to areas with shallow groundwater levels. For these areas, plant material with an isohydric water use behaviour (e.g., clones of the poplar hybrid J-105), should be selected to avoid excessive transpiration rates. In this case, SRC water use will most likely be comparable to water use of deciduous forests, but will be lower than evapotranspiration of coniferous forests. Particularly, the water balance of coniferous Scots pine forests, which predominate in the area, is considered to conflict the requirements of groundwater protection, not least because of too low groundwater recharge rates. From this perspective, SRC cultivation might reduce overall groundwater recharge, but not in an extent that would put groundwater resources at risk.

\subsection{Conclusions}

The aims of this dissertation were to evaluate the environmental impacts of SRC cultivation with respect to the amount and quality of groundwater recharge, and to provide information on SRC water use at the field scale for developing adaptive, sustainable management strategies for woody biomass production systems. An assessment of nitrate leaching induced by SRC cultivation in the Fuhrberger Feld confirmed the general recognition of SRCs as a sustainable, environmental friendly bioenergy production system, even when increased requirements for groundwater protection have to be taken into account. However, a major concern of large scale SRC implementation are adverse hydrological effects on local water balances caused by a high water consumption. Based on field studies and modelling experiments on evapotranspiration and groundwater recharge conducted in different SRCs of contrasting pedo-climatic site conditions, canopy closure and leaf area index, the dissertation at hand was able to show that the recently questioned (Fischer et al., 2018) reputation of willows and poplars being great water consumers does not appear to be unfounded. When water supply is ample, transpiration of poplar SRCs with a dense canopy and high leaf area can indeed by far exceed transpiration of deciduous forests, and a considerable reduction in groundwater recharge can be expected at the field scale, when SRCs replace annual food or bioenergy crops. However, the water availability for the majority of sites potentially available 
for SRC cultivation (i.e., arable land of low productivity) will be low and far from fully satisfying the high water demand of trees on arable land, which provides a safeguard for a minimum amount of groundwater recharge. This relation, and the fact that the hypothesis of SRC water use being higher than water use of deciduous forests had to be rejected, even for a site with very high water demand, justifies the conclusion that a reduction of groundwater recharge in most areas will be moderate. Positive environmental aspects will outweigh potential negative effects of SRC cultivation arising from a high water demand in most areas, but have to be individually assessed using spatial planning tools.

Current climate change scenarios project a shift in the precipitation regime towards higher off-season precipitation and lower in-season precipitation for Germany (Hübener et al., 2017), supporting the above made evaluation of mostly moderate impacts on the amount of groundwater recharge. However, rising temperatures and more frequent summer droughts also highlight the need for increasing the water-efficiency of woody biomass production systems by informed management decisions, for which this research was able to contribute information by evaluating several determinants potentially affecting SRC water use. In this context, information was provided how to potentially decrease understorey transpiration and soil evaporation by management in young SRCs before canopy closure, which were eventually responsible for rejecting the hypothesis of evapotranspiration in young SRCs being lower than E in mature SRCs with high leaf area and densely closed canopy. The only management option to effectively influence SRC water use in an extent that potentially also affects the amount of groundwater recharge, however, appears to be a specific selection of plant material according to its water use behaviour. While an isohydric water use strategy could be confirmed for one of the investigated poplar hybrids $(J-105)$ that showed comparatively low transpiration rates, evidence for anisohydric behaviour causing high transpiration rates was recently reported (Navarro et al., 2018). In order to enable an informed selection of clone material according to its water use behaviour, it is of key importance to provide systematic information on the individual water use behaviour of commercially available poplar and willow hybrids, especially when the area requirements for the production of woody biomass increases significantly, but also with regard to climate change. 


\section{References}

Baumgarten, M., Weis, W., Kühn, A., May, K., Matyssek, R., 2014. Forest transpirationtargeted through xylem sap flux assessment versus hydrological modeling. Eur. J. For. Res. 133, 677-690. https://doi.org/10.1007/s10342-014-0796-4

Federer, C.A., Vörösmarty, C., Fekete, B., 1996. Intercomparison of methods for calculating potential evaporation in regional and global water balance models. Water Resour. Res. 32, 2315-2322. https://doi.org/10.1029/96WR00801

Fischer, M., Trnka, M., Kučera, J., Deckmyn, G., Orság, M., Sedlák, P., Žalud, Z., Ceulemans, R., 2013. Evapotranspiration of a high-density poplar stand in comparison with a reference grass cover in the Czech-Moravian Highlands. Agric. For. Meteorol. 181, 43-60. https://doi.org/10.1016/j.agrformet.2013.07.004

Fischer, M., Zenone, T., Trnka, M., Orság, M., Montagnani, L., Ward, E.J., Tripathi, A.M., Hlavinka, P., Seufert, G., Žalud, Z., King, J.S., Ceulemans, R., 2018. Water requirements of short rotation poplar coppice: Experimental and modelling analyses across Europe. Agric. For. Meteorol. 250-251, 343-360. https://doi.org/10.1016/j.agrformet.2017.12.079

Gerwin, W., Repmann, F., Galatsidas, S., Vlachaki, D., Gounaris, N., Baumgarten, W., Volkmann, C., Keramitzis, D., Kiourtsis, F., Freese, D., 2018. Assessment and quantification of marginal lands for biomass production in Europe using soil-quality indicators. SOIL 4, 267-290. https://doi.org/10.5194/soil-4-267-2018

Hall, R.L., Allen, S.J., Rosier, P.T.W., Hopkins, R., 1998. Transpiration from coppiced poplar and willow measured using sap-flow methods. Agric. For. Meteorol. 90, 275-290.

Hall, R.L., Allen, S.J., Rosier, P.T.W., Smith, D.M., Hodnett, G., Roberts, J.M., Hopkins, R., Davies, H.N., 1996. Hydrological effects of short rotation energy coppice. Final report to ETSU. Institute of Hydrology, Wallingford.

Hübener, H., Bülow, K., Fooken, C., Früh, B., Hoffmann, P., Höpp, S., Keuler, K., Menz, C., Mohr, V., Radtke, K., Ramthun, H., Spekat, A., Steger, C., Toussaint, F., WarrachSagi, K., Woldt, M., 2017. ReKliEs-De Ergebnisbericht. World Data Center for Climate (WDCC) at DKRZ. https://doi.org/10.2312/WDCC/ReKliEsDe_Ergebnisbericht

Kay, S., Rega, C., Moreno, G., den Herder, M., Palma, J.H.N., Borek, R., Crous-Duran, J., Freese, D., Giannitsopoulos, M., Graves, A., Jäger, M., Lamersdorf, N., Memedemin, D., Mosquera-Losada, R., Pantera, A., Paracchini, M.L., Paris, P., Roces-Díaz, J.V., Rolo, V., Rosati, A., Sandor, M., Smith, J., Szerencsits, E., Varga, A., Viaud, V., Wawer, R., Burgess, P.J., Herzog, F., 2019. Agroforestry creates carbon sinks whilst enhancing the environment in agricultural landscapes in Europe. Land Use Policy 83, 581-593. https://doi.org/10.1016/j.landusepol.2019.02.025

Meesenburg, H., Scheeler, B., Wagner, M., Fleck, S., 2014. Interzeption von Wäldern: eine (zu) wenig beachtete Größe des Wasserkreislaufs. Forum Für Hydrol. Wasserbewirtsch. 34, 199-206.

Navarro, A., Portillo-Estrada, M., Arriga, N., Vanbeveren, S.P.P., Ceulemans, R., 2018. Genotypic variation in transpiration of coppiced poplar during the third rotation of a short-rotation bio-energy culture. GCB Bioenergy 10, 592-607. https://doi.org/10.1111/gcbb.12526

Oren, R., Sperry, J.S., Katul, G.G., Pataki, D.E., Ewers, B.E., Phillips, N., Schäfer, K.V.R., 1999. Survey and synthesis of intra- and interspecific variation in stomatal sensitivity to vapour pressure deficit. Plant Cell Environ. 22, 1515-1526. https://doi.org/10.1046/j.1365-3040.1999.00513.x 
Petzold, R., Schwärzel, K., Feger, K.-H., 2011. Transpiration of a hybrid poplar plantation in Saxony (Germany) in response to climate and soil conditions. Eur. J. For. Res. 130, 695-706. https://doi.org/10.1007/s10342-010-0459-z

Roberts, J., 1983. Forest transpiration: A conservative hydrological process? J. Hydrol. 66, 133-141. https://doi.org/10.1016/0022-1694(83)90181-6

Tsonkova, P., Böhm, C., Quinkenstein, A., Freese, D., 2012. Ecological benefits provided by alley cropping systems for production of woody biomass in the temperate region: a review. Agrofor. Syst. 85, 133-152. https://doi.org/10.1007/s10457-012-9494-8 


\section{Declaration of originality and confirmation of conformance}

Göttingen, September $1^{\text {st }} 2020$

I, Paul Schmidt-Walter, hereby declare that I am the sole author of this dissertation entitled 'Evaluation of environmental impacts of short rotation coppice with regard to the amount and quality of groundwater recharge'. All references and data sources that were used in the dissertation have been appropriately acknowledged.

I furthermore declare that this work has not been submitted elsewhere in any form as part of another dissertation procedure.

Moreover, I confirm that the contents of the digital version are identical with the written scientific treatise.

Paul Schmidt-Walter 


\section{Copyright clearance}

This dissertation contains the print versions ("Published Journal Article", PJA) of two articles published in scientific journals for which the rights of use are briefly described here.

The first article (Chapter 2) entitled "Biomass Production with Willow and Poplar Short Rotation Coppices on Sensitive Areas-the Impact on Nitrate Leaching and Groundwater Recharge in a Drinking Water Catchment near Hanover, Germany" (Bioenergy Research (2012) 5:546-562; DOI 10.1007/s12155-012-9237-8) has been published under the Open Access licence "Creative Commons Attribution Generic" (CC-BY 2.0). The integration of the print version into this dissertation therefore is legally conform.

The second article (Chapter 3) entitled "Transpiration and water use strategies of a young and a full-grown short rotation coppice differing in canopy cover and leaf area" (Agricultural and Forest Meteorology (2014) 195-196:165-178; DOI 10.1016/j.agrformet.2014.05.006) does not have an Open Access licence, so the copyright of the article is held by the publisher (Elsevier B.V.). However, the Publishing Agreement for this article grants the authors the rights to share their work for scholarly purposes, without the need to obtain further permission. In particular, the Author Rights include “... the use [of the PJA] by the author in a subsequent compilation of the author's works ... or re-use by the author of portions or excerpts in other works (with full acknowledgment of the original publication of the Article)." At https:/www.elsevier.com/about/policies/copyright/permissions (accessed Oct 20, 2019) Elsevier gives details for the use in a thesis or dissertation: "As an Elsevier journal author, you have the right to include the article in a thesis or dissertation (provided that this is not to be published commercially) whether in full or in part, subject to proper acknowledgment; see the Copyright page for more information. No written permission from Elsevier is necessary." This right extends to the posting of your thesis to your university's repository provided that if you include the published journal article (PJA), it is embedded in your thesis and not separately downloadable." This is the case here, so no legal issues arise from including this subscription article in this dissertation.

The third article (Chapter 4) "An R-package for simulating water fluxes, soil moisture and drought stress using the LWF-Brook90 hydrological model" was also submitted to Elsevier B.V., but the included version did not yet undergo peer review and therefore has the status "preprint". Preprints can be shared on a website or repository at any time, however, after the article was accepted, Elsevier B.V. "encourages the author to include a link to the formal publication through the relevant DOI". This applies to Chapter 4, of which a later version was accepted before the publication of this dissertation. A DOI link to the accepted and published article was included in the title page of Chapter 4. 


\section{Acknowledgements}

First of all, I want to thank my supervisor and examiner Prof. Dr. Norbert Lamersdorf, for accompanying my studies and his unconditional support in any phase of my life I went through during the long time this dissertation took, finally enabling me to finish. Secondly, I express my thanks to Prof. Dr. Alexander Knohl and Prof. Holger Kreft, for examing my thesis and giving me good advice in any question that came up. I also express my thanks to Dr. Mathias Herbst, who drew my attention to studying water use strageties, and his helpfulness and great knowledge in this topic. As well, I would like to thank Dr. Henning Meesenburg for the fruitful discussions on the final straights of my dissertation, and my employer letting me work on my thesis also during office hours.

I also thank Dirk Boettger and Dietmar Fellert, for supporting me during field trips and helping me puzzling all the technical devices for the field measurements, solving any upcoming problems with sophicasted solutions. As well, I want to express my gratitude to Falk Richter and Martina Zacios for offering me their precious field data to work with. I furthermore thank all my colleagues at the Soil Science institute and Northwestgerman Forest Research Station for their support.

Finally, I want to thank my wife and family for supporting and motivating me when necessary. Particularly, I am deeply grateful for my mother-in-law for supporting us over a long period, and my daughter, for giving me time to almost finish writing before arriving in this world. 


\section{Appendix to Chapter 4}

\section{A LWFBrook90R - Installation and sample data}

\section{A1 Installation}

In this document, we will describe the prerequisites for reproducing the application examples presented in the paper. Before installing LWFBrook90R, you will need to install the packages that LWFBrook90R imports:

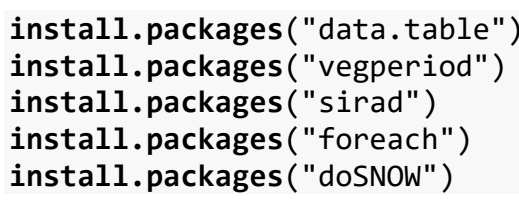

Now, LWFBrook90R can be installed. Please download and install the latest stable release from https://github.com/pschmidtwalter/LWFBrook90R/releases.

install.packages("path/to/package/LWFBrook90R_0.2.0.tar.gz", repos = NULL, type = "source") For installing the source package in R under Windows, Rtools is required. If Rtools is not available, install the (.zip) binary package:

install.packages ("path/to/package/LWFBrook90R_0.2.0.zip", repos = NULL, type = "binary")

You can also install the latest stable release directly from GitHub, using the devtools package:

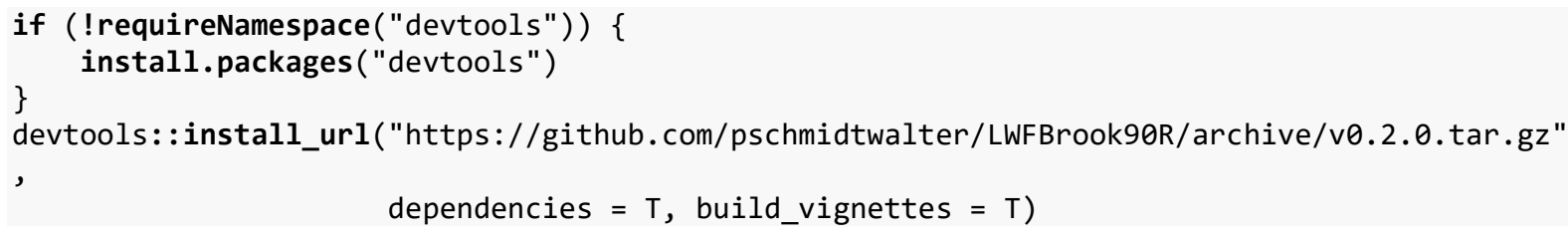

\section{A2 Reproduction of examples}

In order to reproduce the examples from the Appendix, please also install the following packages.

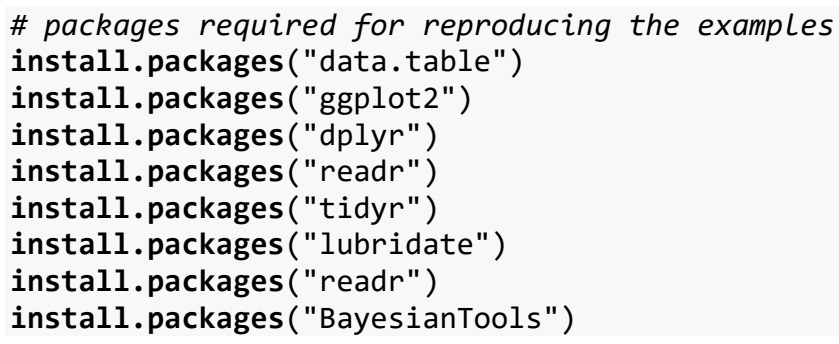

The required data for this Appendix $(A)$ and Appendix B is available after loading the package. Prepared data and simulation results for Appendices $C$ and $D$ are provided separately, so that the examples can be conducted without running the large multirun applications. The data is linked to this Article. Please download and unzip the data and place the 'DataAndPreparedResults' folder inside the R working directory when conducting Appendices C and D. 


\section{A3 LWFBrook90R: Basic usage and set up}

After having installed the required packages, you can load the LWFBrook90R package to make a test simulation. We also load data.table and ggplot2 for the graphics.

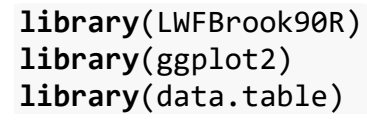

The central function to run LWF-Brook90 from within R is runLWFB90. When called, the function will

- create model input from climate driving data, model control options and parameters,

- $\quad$ execute the model,

- $\quad$ read and return the created output files.

Before using runLWFB90, the required input objects need to be set up. These are passed as arguments to the function. Aside from meteorological and soil data, lists have to be defined containing the model control options and model parameters. The list of model options contains basic information about the simulation (e.g. the start and end dates of the simulation, the precipitation interval) and which submodels to use for input generation (e.g. phenology model, leaf area index dynamics, root length density depth distribution function, etc). The second list contains the model parameters. Most of the parameters are required to run the model, but some only take effect if certain model options are selected. Two functions are defined in LWFBrook90 that can be used to create default lists of model options and parameters:

options.b90 <- setoptions_LWFB90()

param.b90 <- setparam_LWFB90()

The created lists can either be manipulated by reference, or simply by assigning values to the option and parameter names directly in the function calls. To look up the meanings of the various options and parameters see ?setoptions_LWFB90 and ?setparam_LWFB90.

We want to run the simulations for the Solling Beech Experimental site SLB1. The meteorological data (slb1_meteo) and soil physical data (slb1_soil) of the site are available after loading the package. Before using them in the simulation, hydraulic parameters have to be derived for the soil layers using a pedotransfer function, provided with the package:

soil <- cbind(slb1_soil, hydpar_wessolek_mvg(slb1_soil\$texture))

As a last step, the output data sets need to selected. The user can choose from different groups of model output in varying temporal resolution. The selection is passed as $[5,10]$-matrix to runLWFB90. The function setoutput_LWFB90 creates a matrix with a default set of selected output datasets: annual, monthly and daily evapotranspiration datasets, and daily values of soil water status variables for each soil layer.

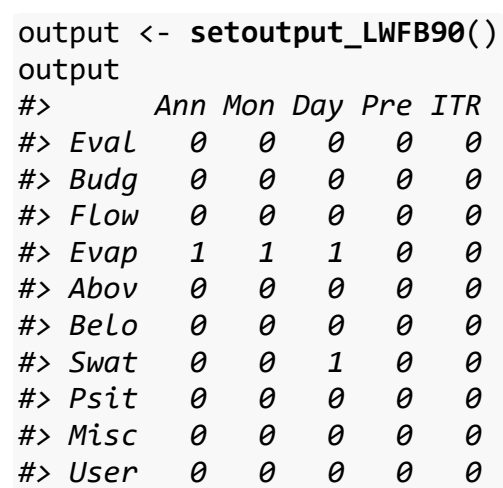

Now we are ready to perform a test simulation with runLWFB90:

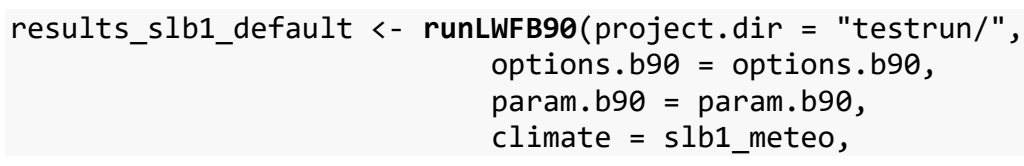




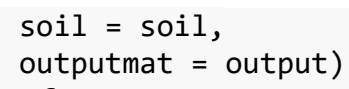

The returned object is a list containing the model output data.tables as specified by the outputmat-argument (and named according to the produced output files), along with options, parameters and derived daily vegetation properties used in the simulation (results_slb1_default\$model_input). We want to plot daily transpiration (TRAN-column in results_slb1_default\$EVAPDAY.ASC), along with daily water storage of the soil profil. We use the ggplot2-package for displaying the results.

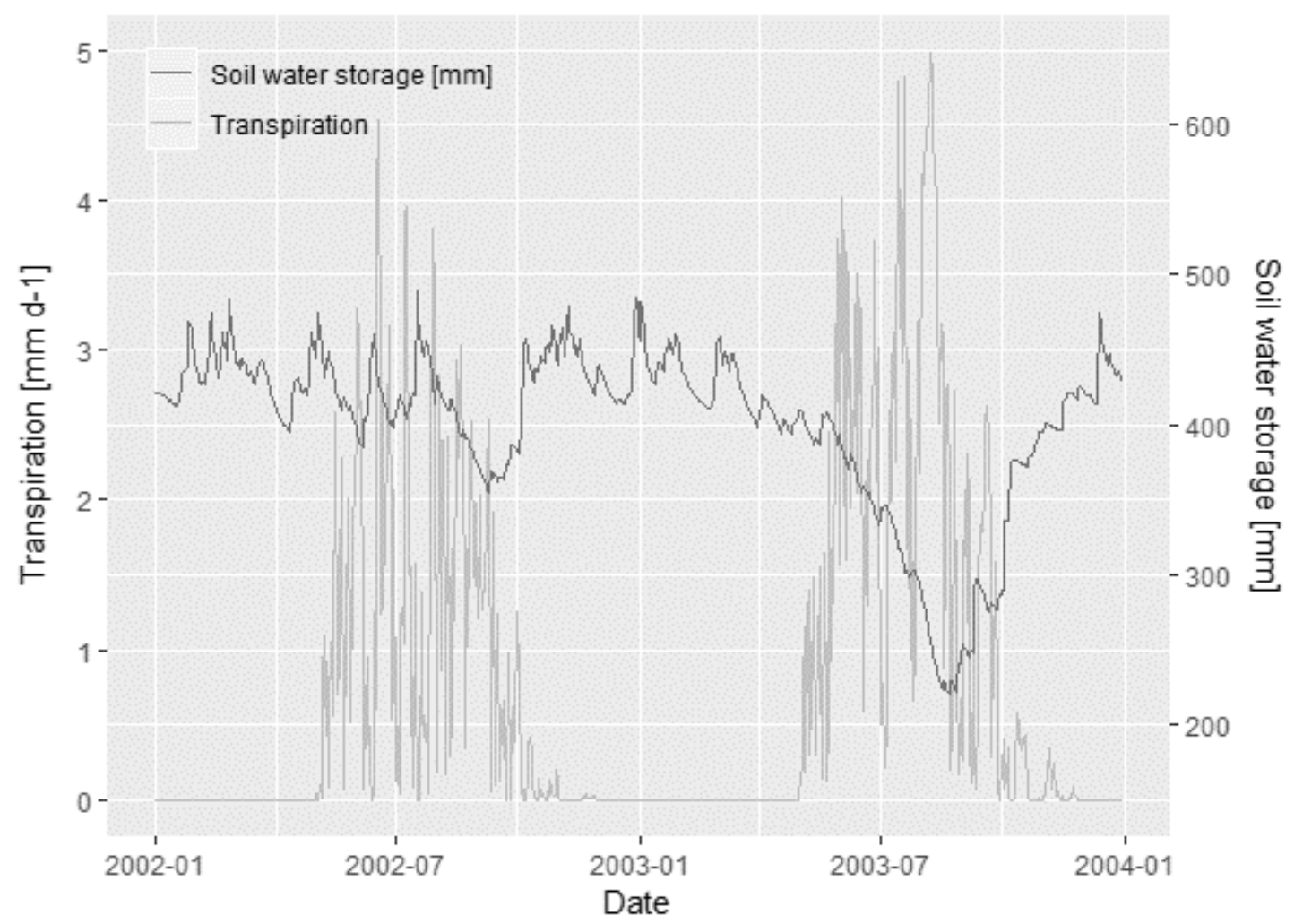

\section{B Conducting single runs with LWFBrook90R}

In this vignette we will run several simulations for the Solling Beech Experimental site using different vegetation covers. The script assumes that all packages, as suggested in Appendix A, are installed. First of all, load the 'LWFBrook90R' package, and the 'data.table' and 'ggplot2' packages:

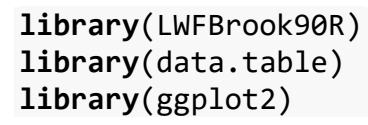

\section{B1 Simulation set up}

Now we set up three simulations, that reflect the hydrology of three different vegetation covers: an evergreen forest stand, a deciduous forest stand and a temperate grassland for the period 1981-2010. The simulations feature dynamic estimation of the dates of budburst and leaffall using different methods based on air 
temperature. The root density depth distribution is estimated from parameters using the -model. As output, we select the daily and monthly evapotranspiration and daily soil water status datasets.

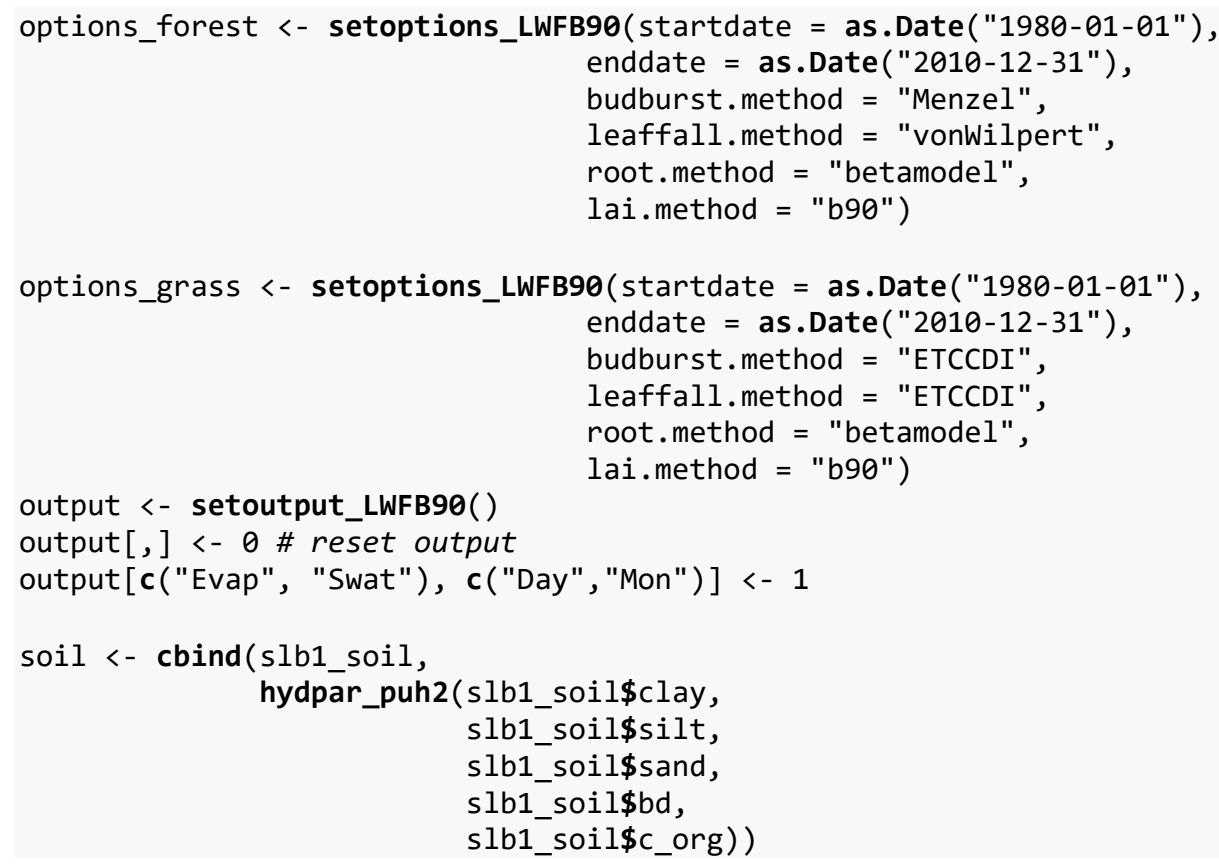

\section{B2 Definition of paramaters}

Now we set up the parameters for the three vegetation covers:

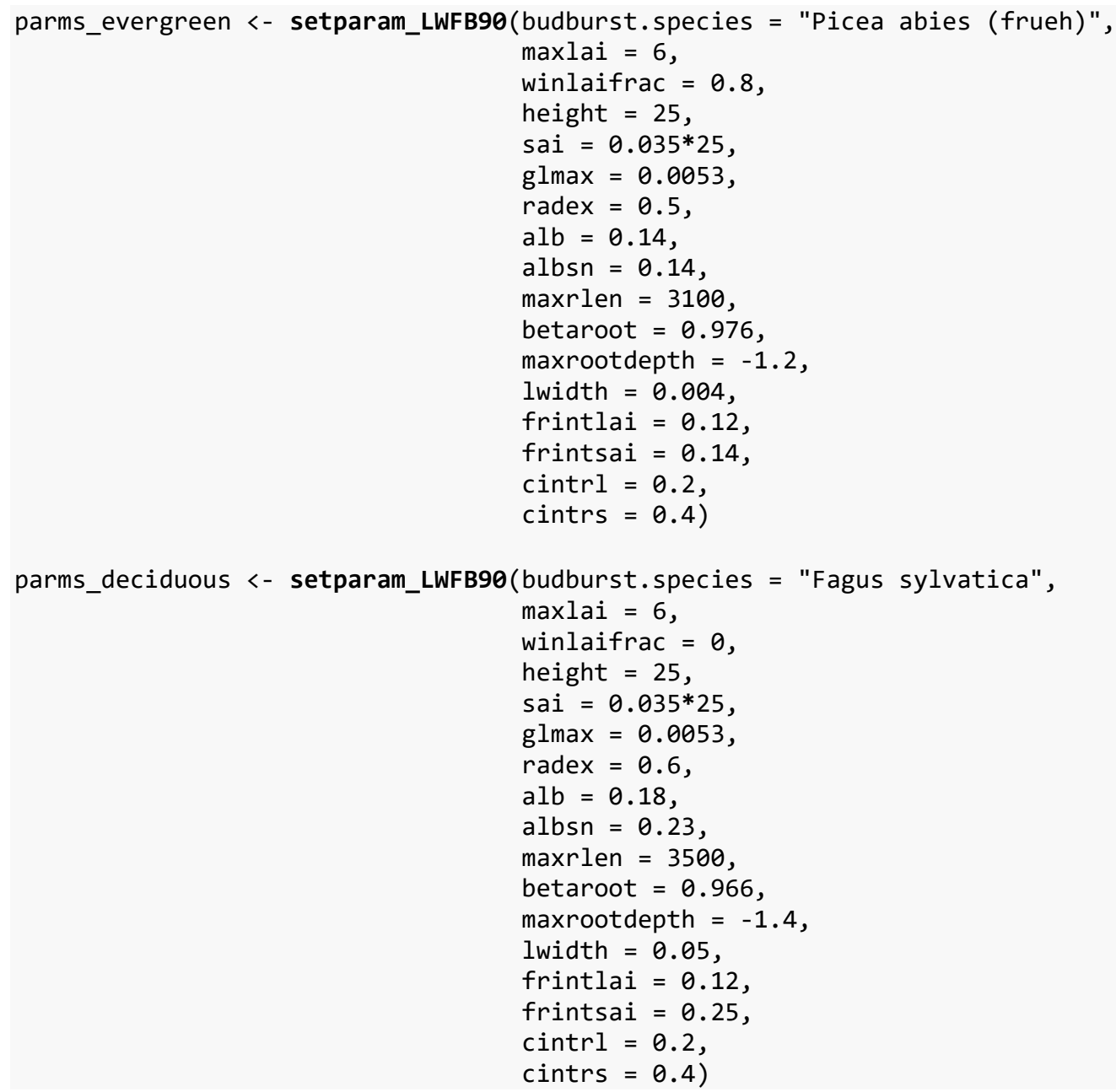




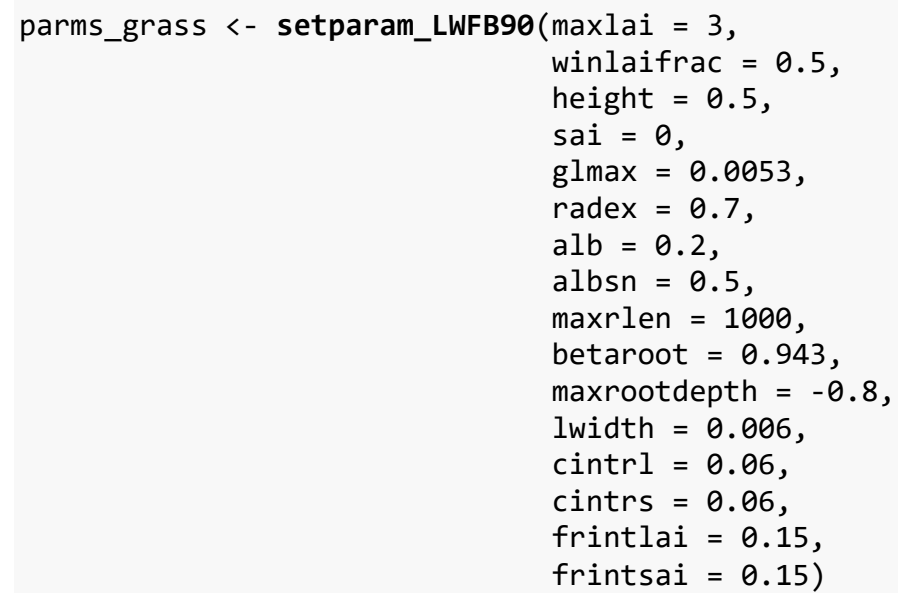

\section{B3 Simulation}

Now we can run the simulations:

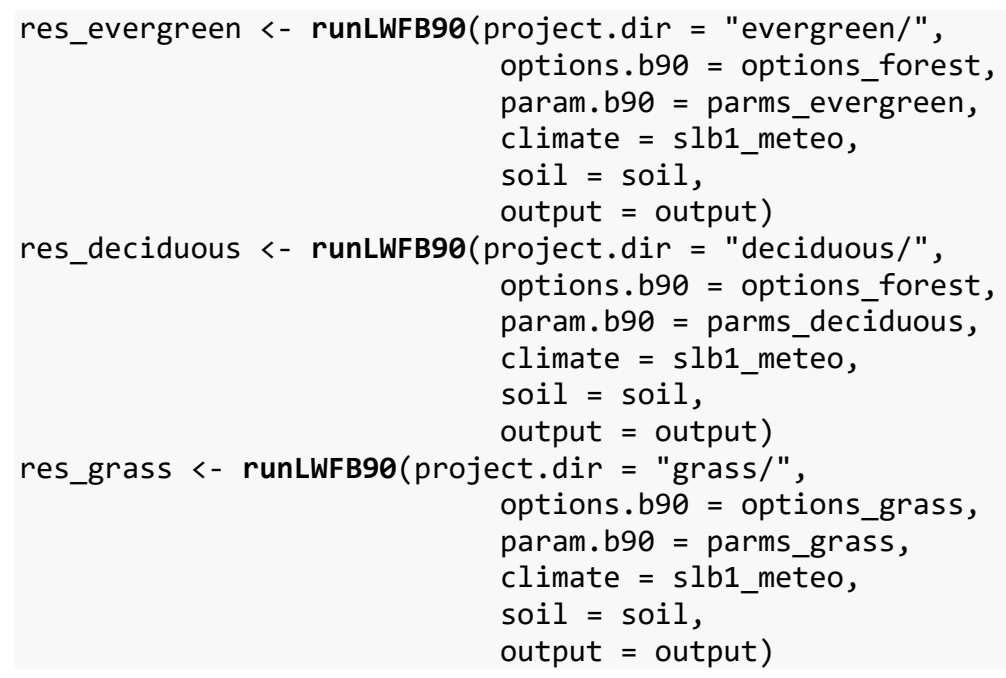

Now we can plot mean monthly waterfluxes for the years 1981-2010.

\# rbind Evap-fluxes from result-lists

fmon <- rbindlist(list (evergreen = res_evergreen\$EVAPMON.ASC, deciduous $=$ res_deciduous\$EVAPMON.ASC, grass = res_grass\$EVAPMON.ASC), idcol = "vegetation")

\# aggregate all variables to monthly mean values fmon_m <- fmon[, lapply(.SD, mean), by = list(vegetation, MO)]

\# melt

hgts <- melt(fmon_m[, list(vegetation, MO, GEVP $=$ ifelse $((S L V P+S N V P)<0,0, S L V P+S N V P)$ $I E V P=I R V P+I S V P$, 

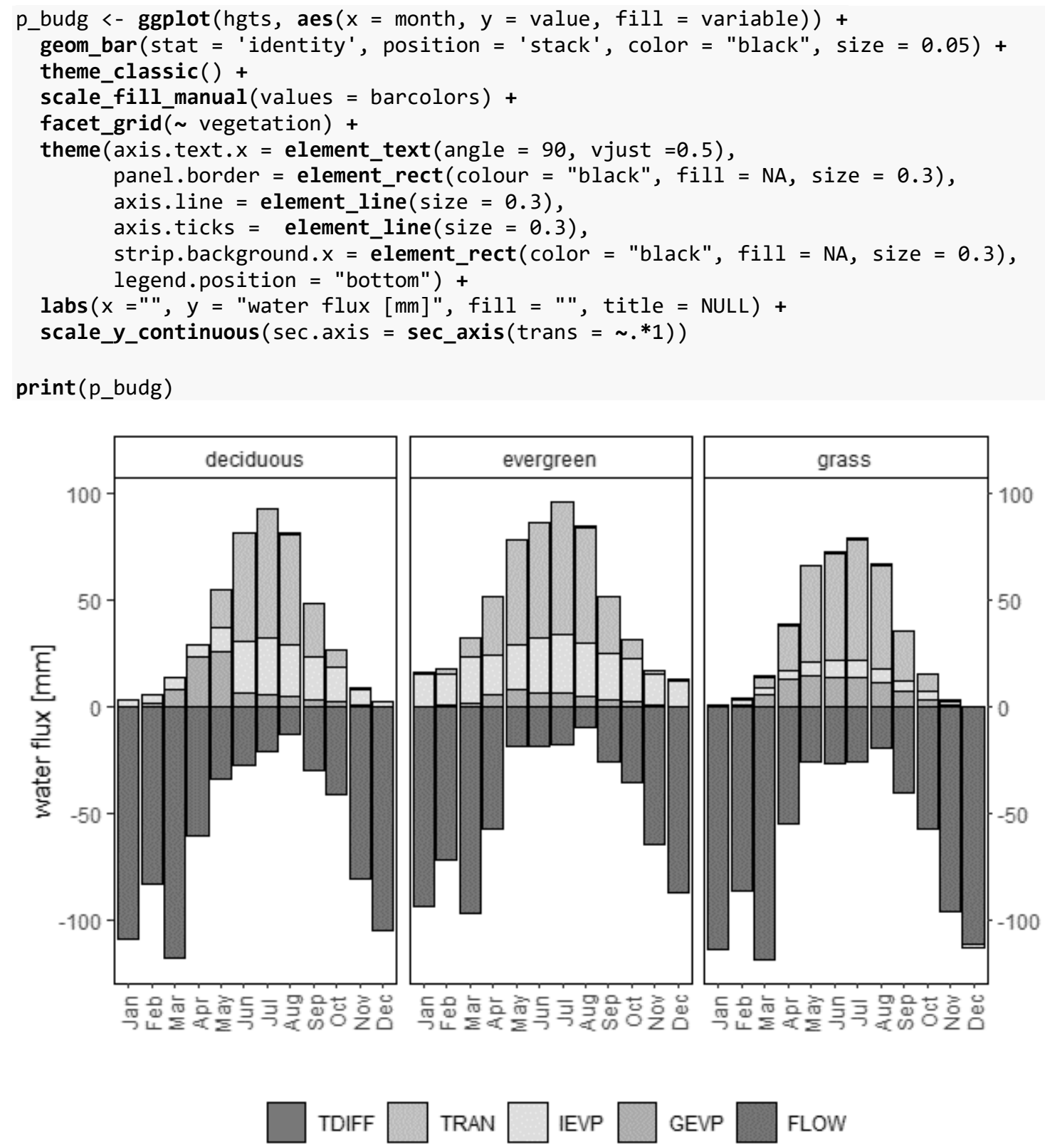

And we plot the daily mean matrix potential depth distribution from 1981-2010, as a measure of soil water availability.

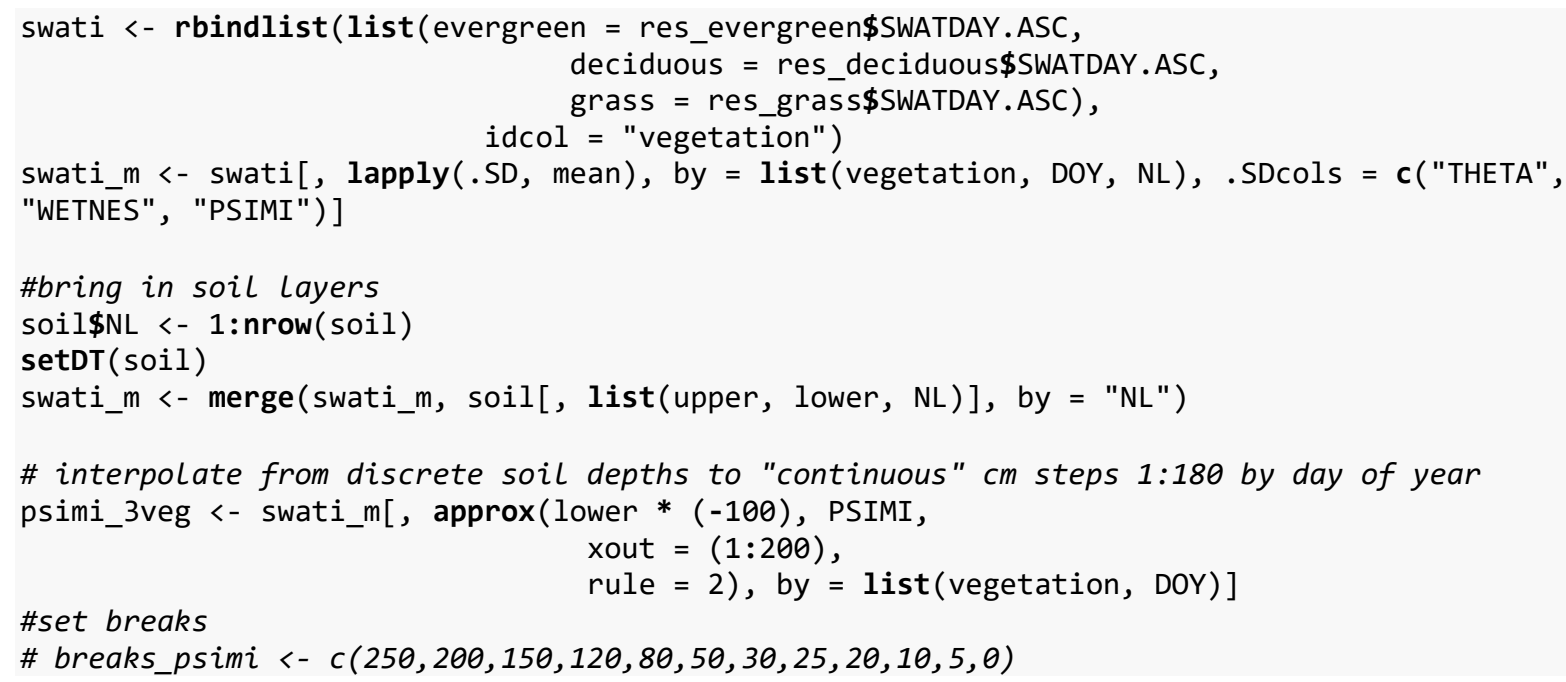



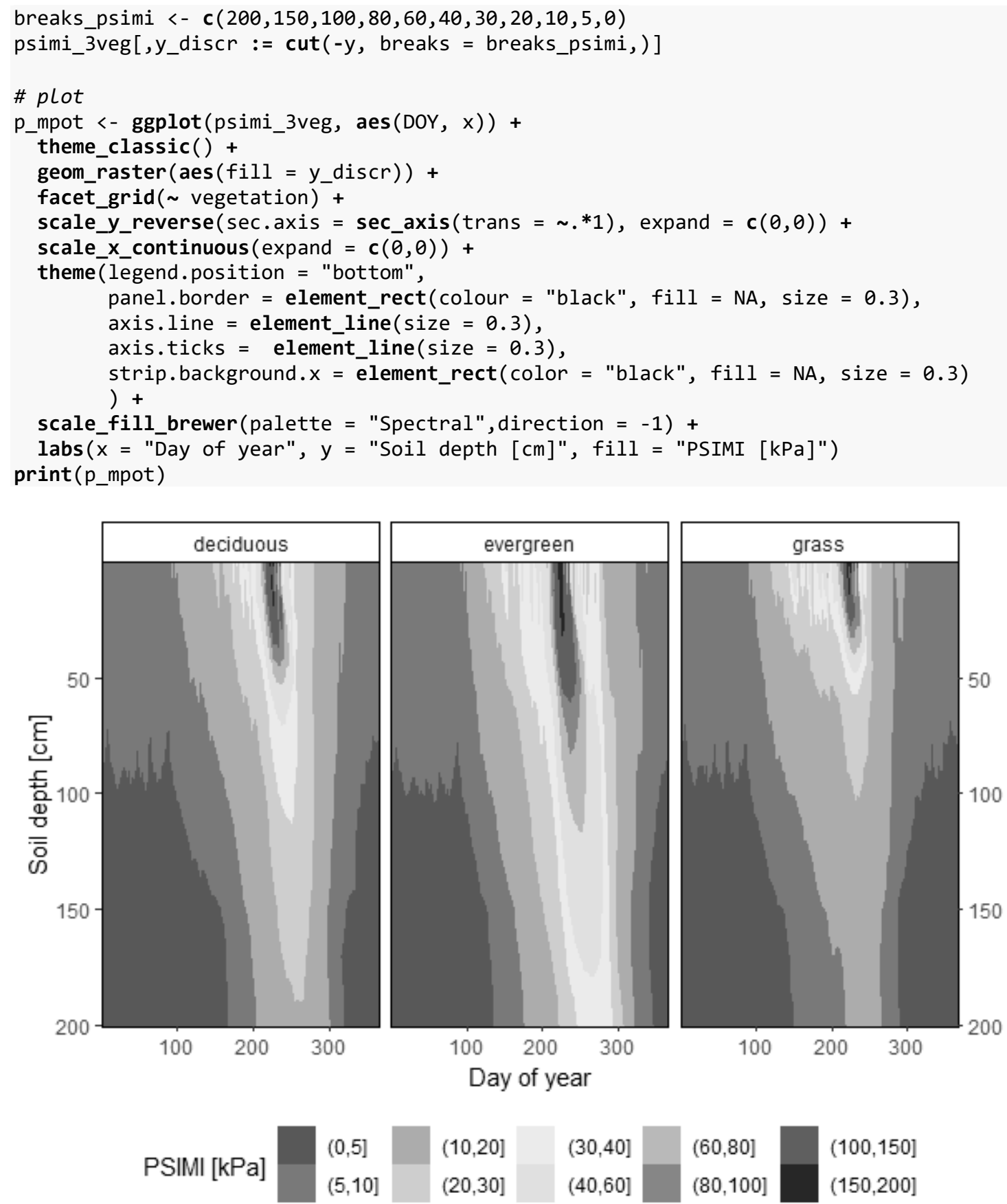

$(30,40]$

$(40,60]$

$(60,80]$

$(80,100]$

$(150,200]$ 


\section{Calibration \& sensitivity analysis of "Kaufering Pappel Schacht 2011-2012"}

In this script a sensitivity analysis using Monte Carlo Filtering (MCF) and a GLUE-calibration ('generalized likelihood uncertainty estimation') are performed, referenced by daily soil water storage for a Poplar short rotation coppice located in Kaufering. As well, a forward prediction using the calibrated parameters is made monthly water fluxes are plotted with their uncertainties. For model calibration and forward prediction, the function mrunLWFB90 is used, which offers a full parallelization of model runs. It is suggested to run the previous singlerun examples, to get familiar with the LWFBrook90R-package. Also, be sure to download and unzip the folder 'DataAndPreparedResults.zip' to be able to load prepared results and input data to the Rworkspace. See Appendix A for details.

Monte Carlo Filtering and GLUE calibration require the following steps:

- $\quad$ set up ranges for random uniform parameter distribution (prior distribution)

- create a sample from the prior distribution

- $\quad$ run the model for each of the parameter sets and save the result of interest

- calculate a goodness of fit measure and choose a threshhold for acceptance of simulations

- classify simulations into behavioral and non-behvaioral, based on the goodness of fit threshold

- $\quad$ view model performance of behavioral simulations

- compare the parameter of distributions of behavioral and non-behavioral distribution to estimate parameter importance for model output.

Before we start the analysis, we need to load the required packages.

library (LWFBrook90R)

library (data.table)

library(ggplot2)

\section{C1 Model set up}

As a first step, we set up the basic simulation settings and read in the climate input data. The simulation spans the years 2010 to 2011. The results for the year 2010 are only used for the model to 'swing-in' and are excluded from all further investigations. The results from 2011 are used for the sensitivity analysis and GLUE calibration, and a forward prediction is later made covering the years 2011 and 2012 . We will analyse the sensitivity of model performance regarding observed total water storage in $0-200 \mathrm{~cm}$ soil depth, thus we select daily SWAT dataset (SWATDAY.ASC) as output.

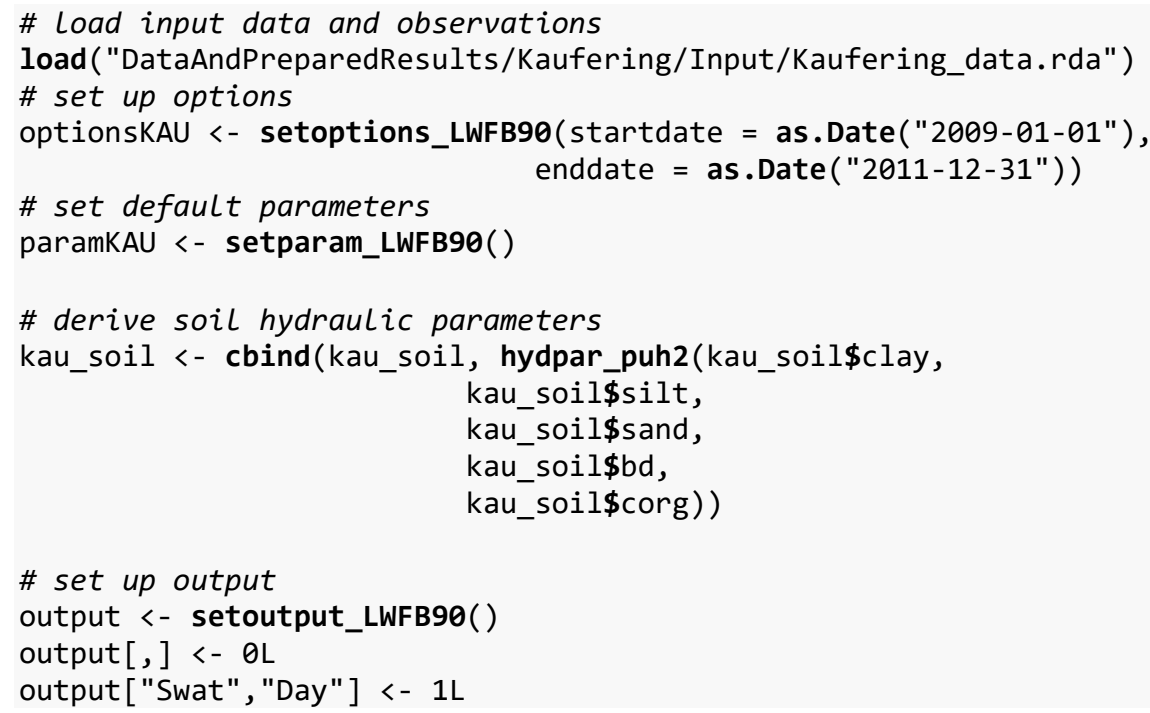

We will use the mrunLWFB90-function, for which parameter variation can be supplied by the paramvarargument, a data.frame with the parameters in columns and their realisations in rows. For each of the rows in paramvar, the parameters in param.b90 are replaced by name, and the single run function runWLFB90 is 
executed. in order to include variation of soil parameters into the simulation, the soil needs to be attached as soil_nodes and soil_materials to the list of parameters, instead of being passed via the soil-argument. The function soil_to_param splits up the soil into unique soil materials and soil layers.

soillaymat <- soil_to_param(kau_soil)

paramKAU\$soil_materials <- soillaymat\$soil_materials

paramKAU\$soil_nodes <- soillaymat\$soil_nodes

Before setting up the parameter variation, we set up some standard parameters that are kept fixed during the multi-run simulation. maxlai and canopy height are roughly set to values observed at the site. $\mathrm{zw}$ is the measuring height of windspeed, coords_y is latitude, needed in LWFBrook90 to estimate daylenth and insolation. We exclude maxlai from variation, as it basicly serves as a scaling factor for many parameters affecting interception and potential transpiration. This leads to many intercorrelations, and can mislead the analysis.

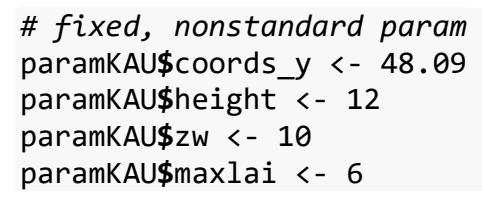

\section{C2 Parameter variation (prior distribution)}

Now we set up the parameter variation using random uniform distributions and a sample size 30000 . We use scaling factors to vary the parameters ths and ksat of all layers simulatenously. Using the scaling factors, the values of the single layers are subsequently defined from the original layer value and the scaling factor. As a last step, we save our parameter sample.

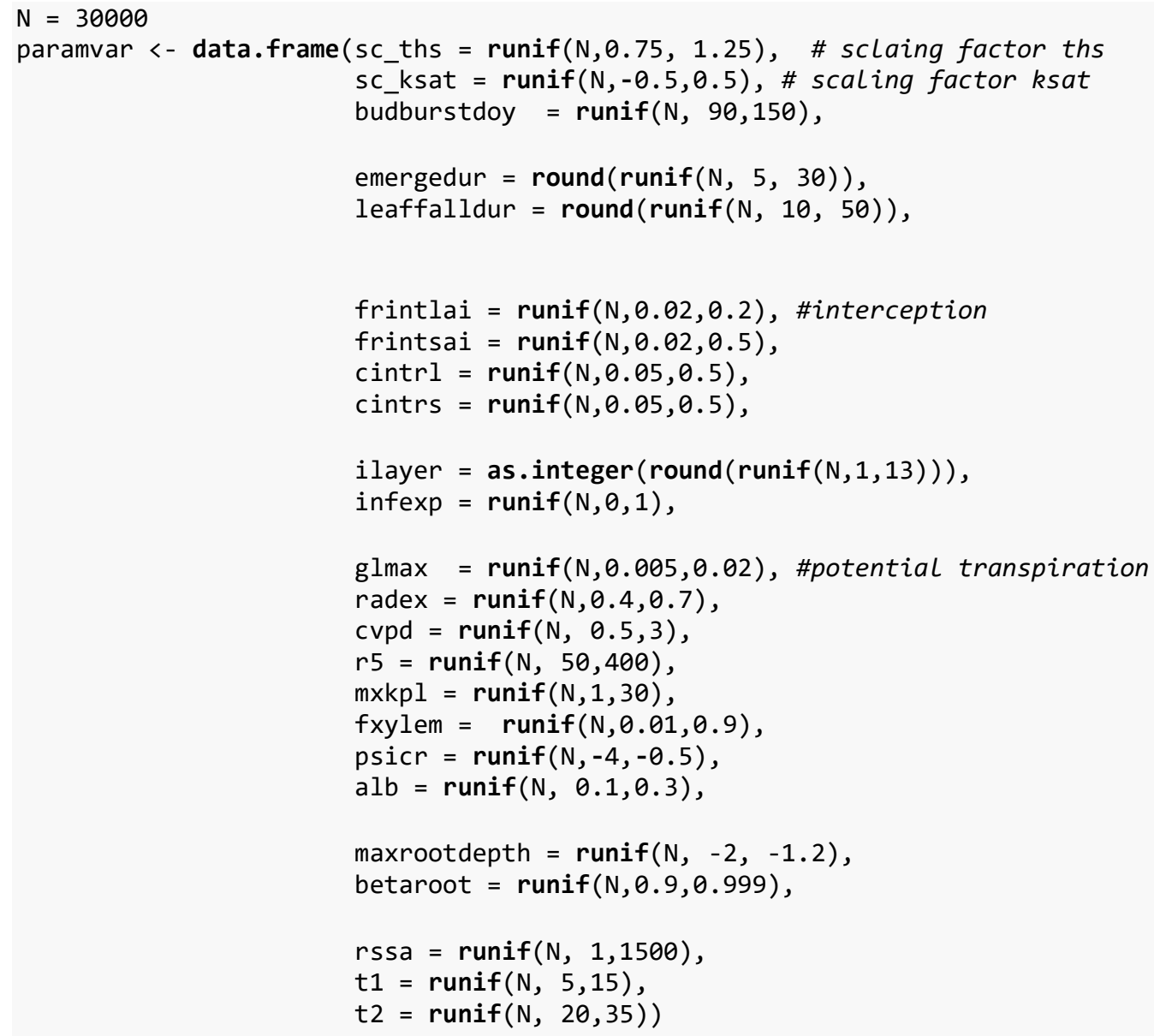

\# calculate soil parameters based on scaling factors:

paramvar\$soil_materials.ths1 <- paramKAU\$soil_materials\$ths[1]*paramvar\$sc_ths 


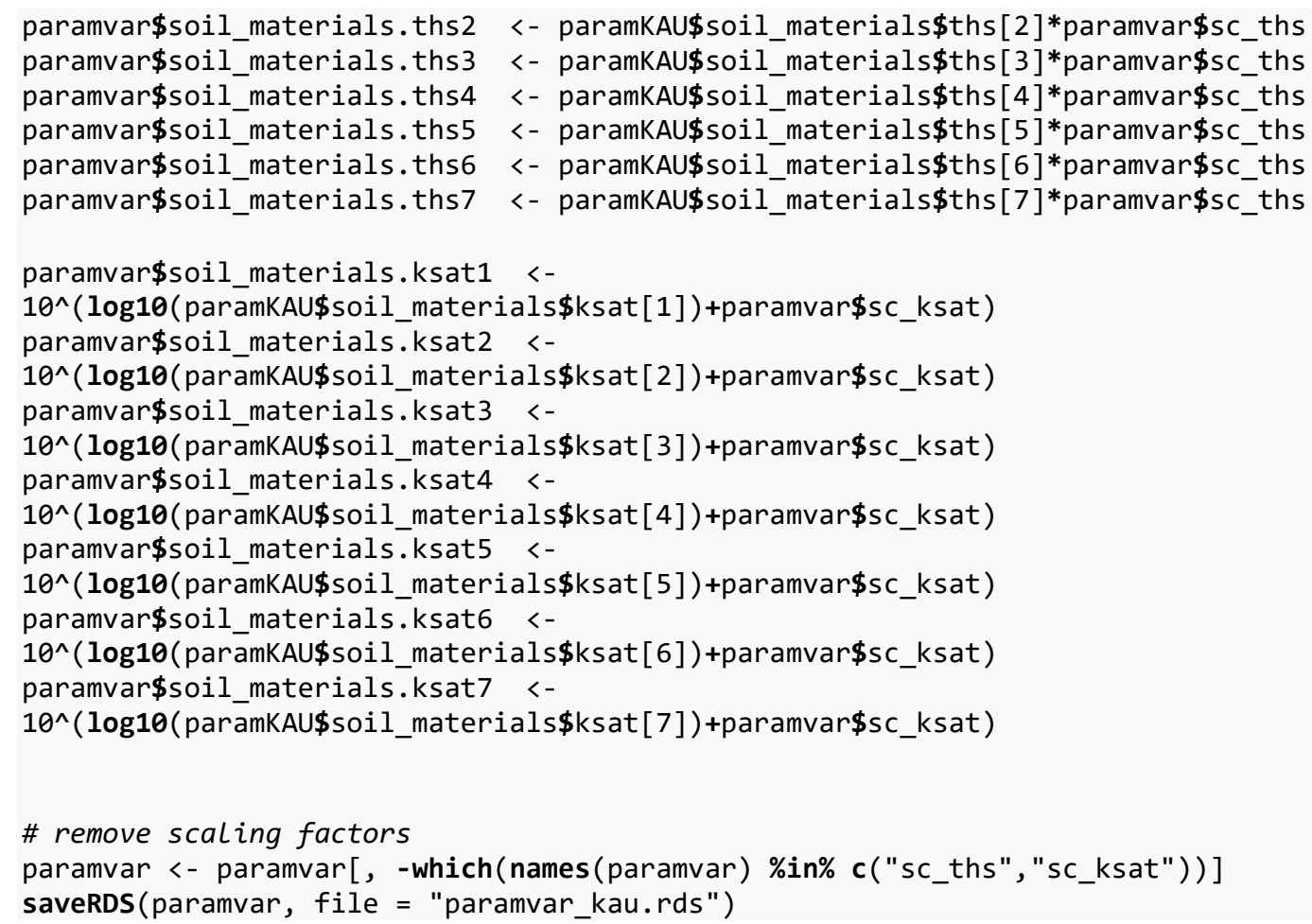

\section{C3 Multirun-Simulation}

In the multirun-simulation we want to run each of the 30000 parameters sets and calculate the Nash-SutcliffEfficiency for the soil water storage in $0-200 \mathrm{~cm}$ soil depth. To do so, we make use of the option to provide a custom function (output_fun) to runLWFB90 that performs on the returned simulation output. The function first aggregates the individual soil layers' water storages to 0-200 cm for 2011 (corresponding to the layer indexes NL 1 to 25), and then uses a function NSE from the 'hydroGOF' R-package, to calculate the NashSutcliff-Efficiency with respect to observeed water storage:

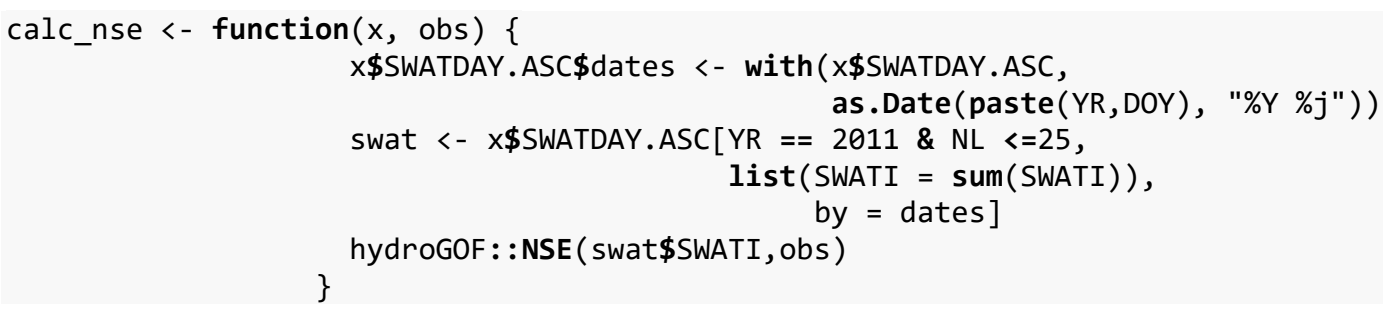

The required model output is available in the returned list item SWATDAY. ASC, that contains the single soil layers' daily water contents and water potentials. To avoid havng to return the whole We define a custom output function (output_fun) that aggregates the single layers' water contents from SWATDAY.ASC to daily soil water storage. It then directly calculates the Nash-Sutcliff-Efficiency of for the single run with respect to observations. In this way, the original simulation output can be discarded ( $r$ trn. output $=\mathrm{F}$ ), to not overload the workspace with the single soil layers' daily water contents and potentials of the 30000 simulations. This would require about $100 \mathrm{~GB}$ memory, which would crash the R-session on most machines.

Now we can start the multirun-simulation. On a computation server using 15 processors, it takes about 5 hours to execute the Multirun. For each row in paramvar, a subdirectory that contains the results of the respective singlerun is created. After a successfull singlerun simulation, the respective subdirectory is removed (keep. subdirs $=$ F), and our custom output function is executed and its results (NSE) appended to the simulation output.

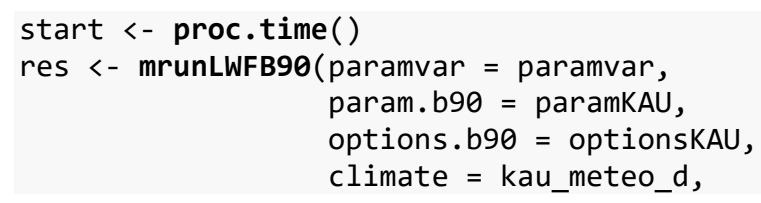




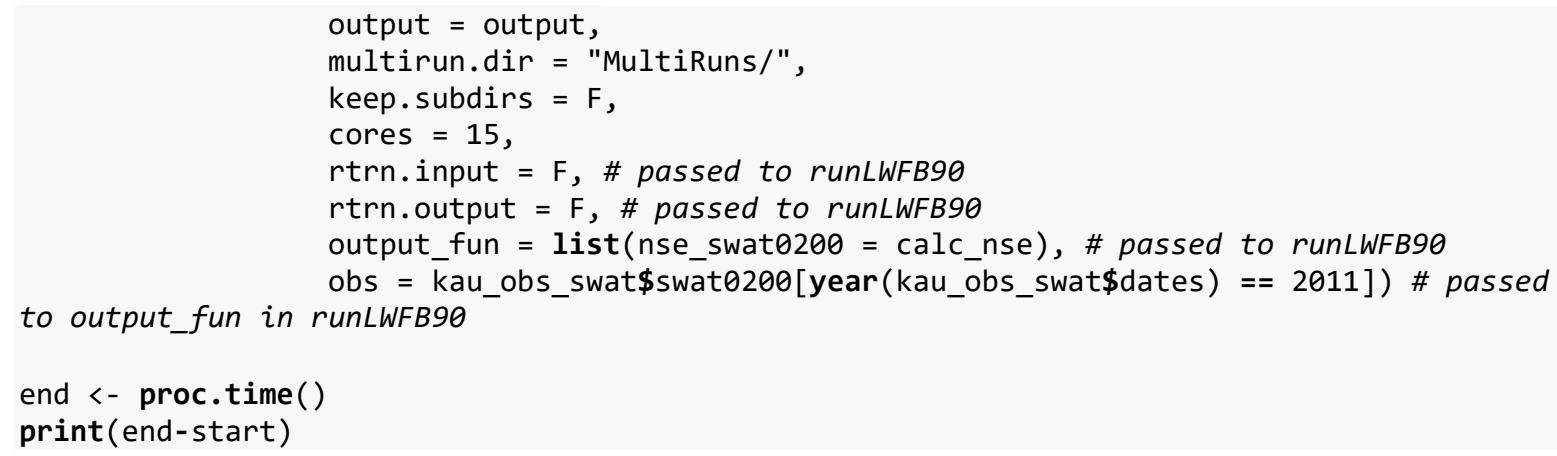

The return value of the mrunLWFB90 is a large list of the returned list-objects from the singleruns. To extract the - NSE values from it we loop over the list and select the scalar values. Subsequently the values are rbind together in a data.table, with an id column "singlerun". After all, we save the list to the folder 'DataAndPreparedResults'.

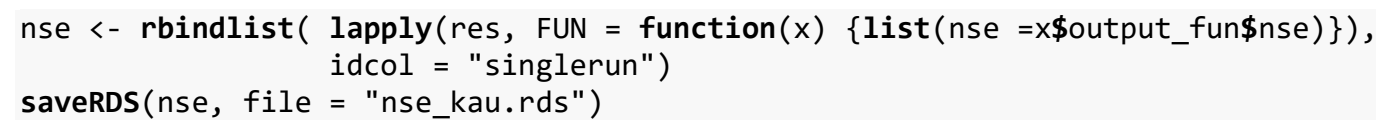

\section{C4 Sensitivity Analysis}

For the sensitivity analysis, we need to load the calculated model efficiencies (nse) and parameter variation table (paramvar) from the previous section back to the workspace.

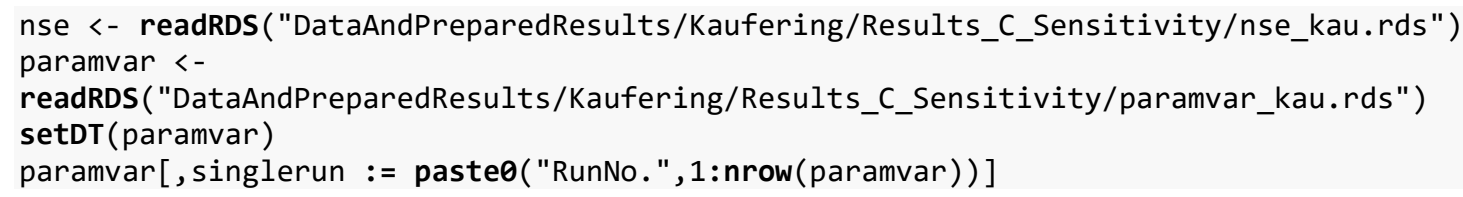

For the Monte Carlo Filtering and GLUE calibration, we set all NSE below a certain threshold to 0 , sort them descending and normalize the behavioural values so that the sum of them gives 1.

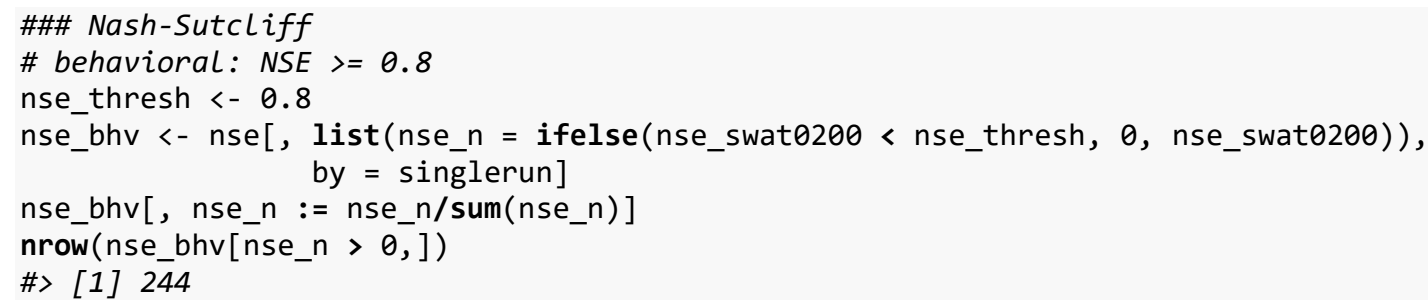

Out of the 30000 simulations, 244 were defined as behavioral by the Nash Sutcliff Efficiency.

\section{C5 Posterior parameter distriutions}

The next step is to check the posterior parameter distribution. We have to extract the simulation identifiers of the behavioral simulations (likelihood $>0$ ) for splitting up the parameters into behavioral and non-behavioral sets. We also save the very best run to plot the parameters of the best solution, and to later plot the model performance for the calibration (2011) and validation period (2012).

beh <- nse_bhv[nse_n > 0 , singlerun]

verybest <- nse_bhv[which.max $\left(\right.$ nse_n$\left._{-}\right)$, singlerun]

To split the input parameter sets, we have to first remove the single layers' soil parameters, that were varied simultaneously using the scaling parameters. We have to recalculate the scaling parameter from the intial soil parameters, because we forgot to save them.

par <- data.table (paramvar, key = "singlerun")

setnames(par, names(par),gsub("soil_materials.", "", names(par))) 


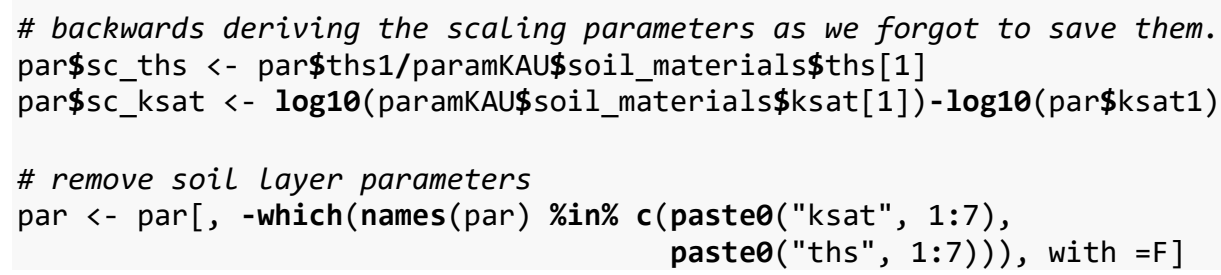

Now we categorize the runs into behavioral and non-behavioral, based on the likelihood. The par-data.table is keyed by the run-identifier, which helps to quickly subset the parameter sets using the run-identifiers character vector.

par[beh, nse_n := "behavioral"]

par[!beh, nse_n := "nonbehavioral"]

For plotting, it is convenient to melt the par-data.table, so that it is in a long format.

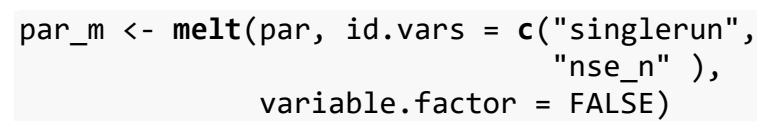

Now we can plot the posterior densities of behavioral simulations runs, including the values of the best parameter set based on the likelihood:

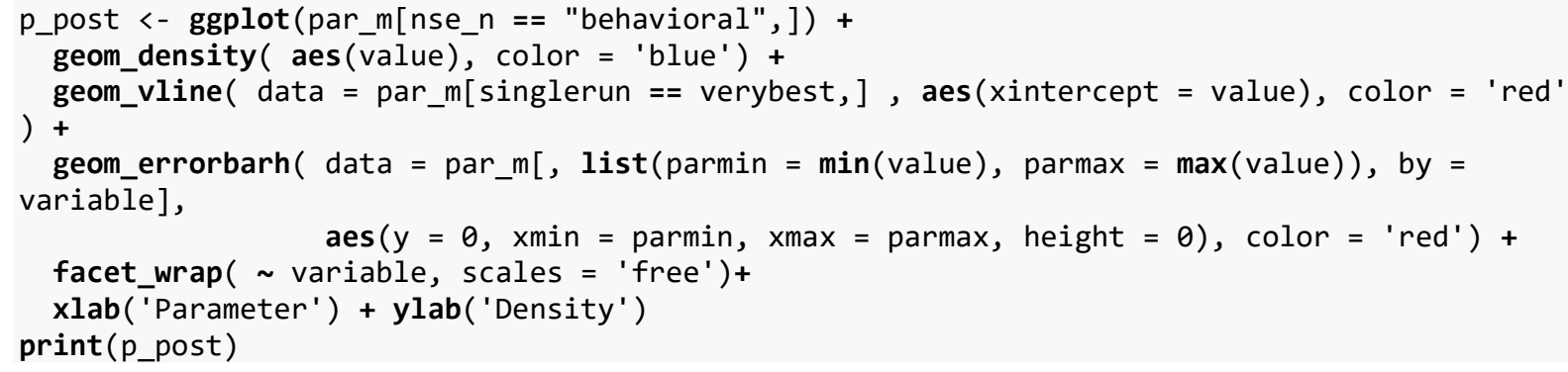



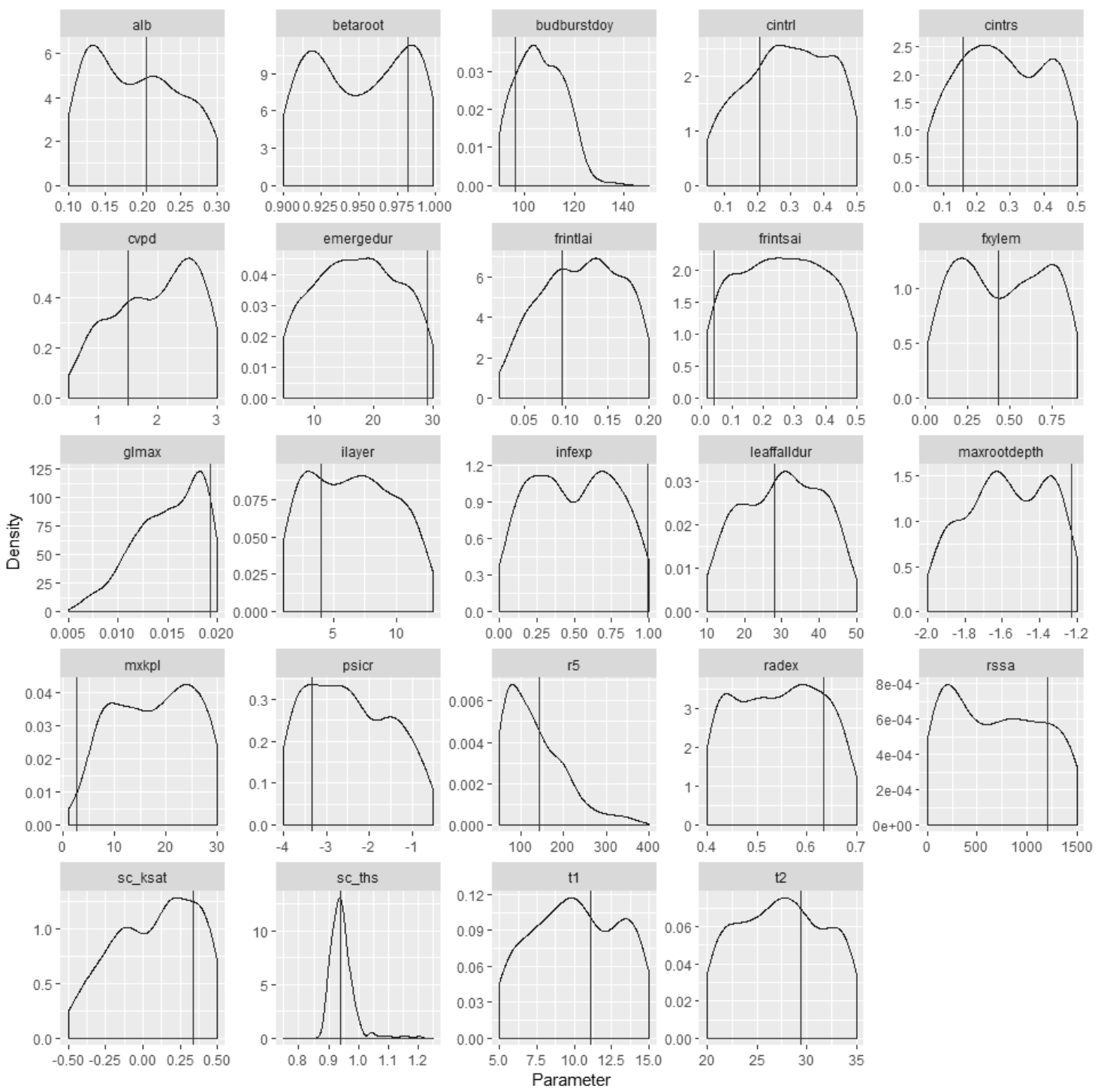

Probality density plots of the posterior (calibrated) parameters (of behvioral) simulations. Red vertical bars mark the parameter values of the best simulation.

\section{C6 Kolgomorov-Smirnov test}

The two-sample Kolgomorov-smirnov test measures the maximum difference $D_{\max }$ between the empirical cumulative distribution functions of two variables, which are here the distributions of the behavioral and nonbehavioral parameter sets. The test can be easily performed for each parameter on the melted par_m that we just used for plotting the posterior parameter densities. To do so, we need to 'cast' the data.table, so that the parameter values of behavioral and non-behavioral runs are organized in two columns. Note that NAs are inserted in the behavioral-column, because there are much less behavioral then non-behavioral simulations.

par_ks <- dcast (par_m, singlerun+variable nse_n)

Now lets perform the test by parameter

ks_results <- par_ks[, as.list(ks.test(behavioral, nonbehavioral, alternative = "two.sided")), by $=$ list (variable)]

ks_results [, statistic := round(statistic, 3 )]

\# order ascending for plotting

ks_results <- ks_results[order(ks_results\$statistic), ]

ks_results $\$$ variable <- factor(ks_results $\$$ variable,

levels = ks_results\$variable) 
and display the results.

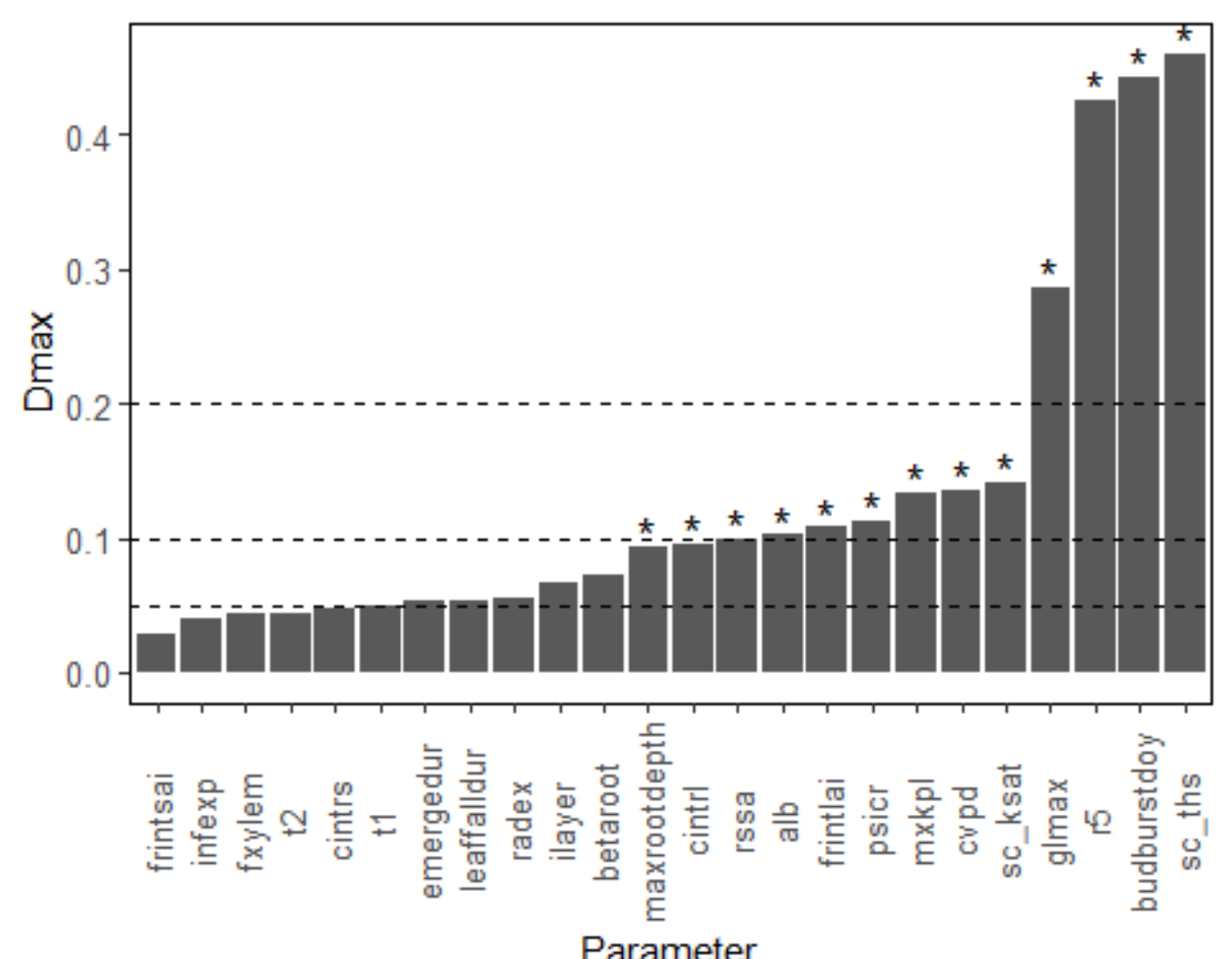

The test statistic $D_{\max }$ is the maximum difference between behavioral and no-behavioral parameters sets. We can plot the empirical cumulative distributions functions using the melted paramater-data.table that also used for plotting the posterior densities:

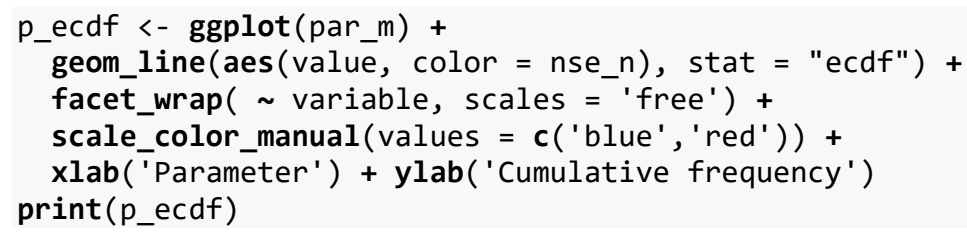




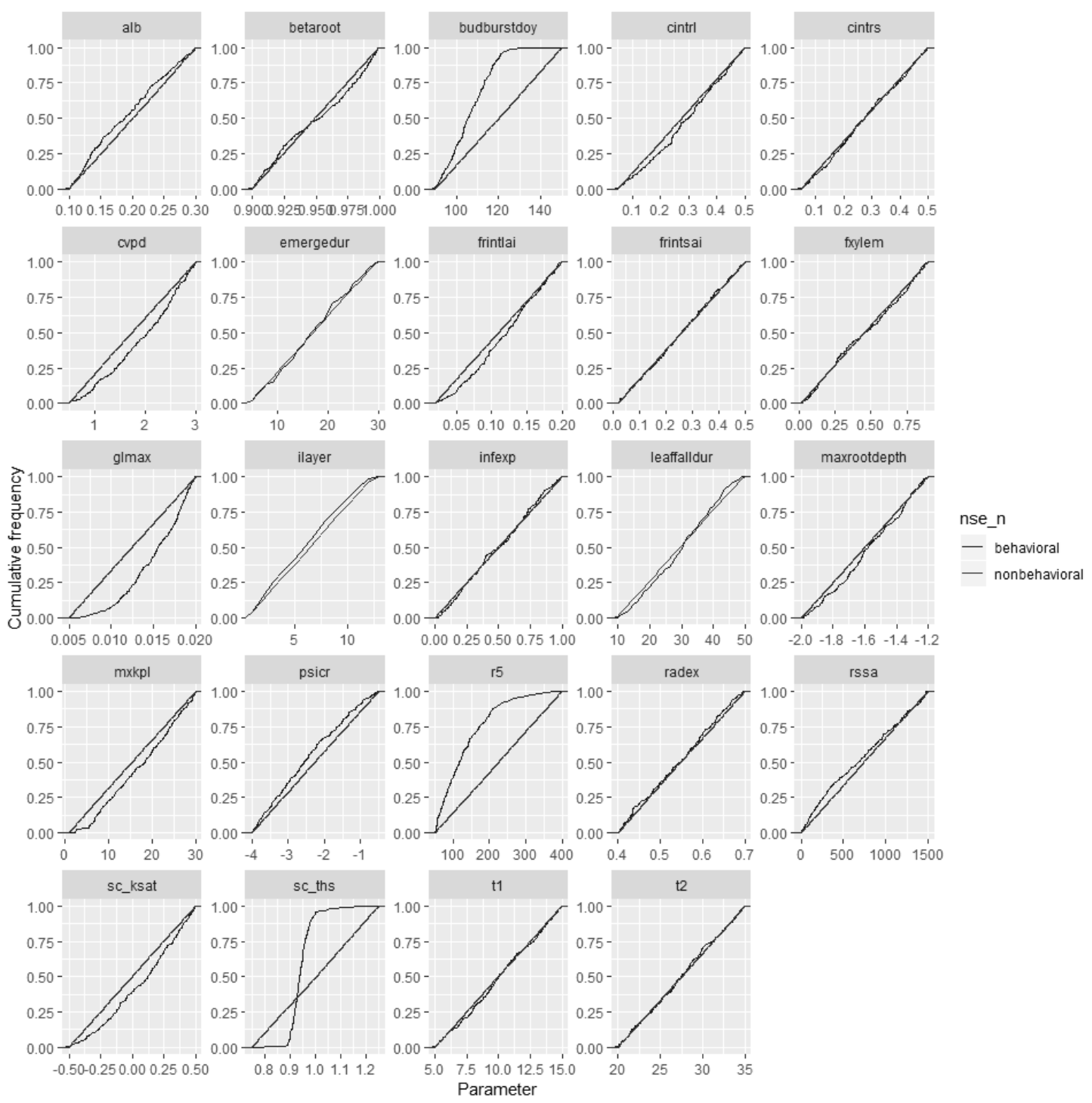

\section{C7 Forward prediction}

After having identified the most important parameters for pushing simulations to the "behavioral region" $(N S E \geq 0.8)$, we would like to see now how the 244 behavioral simulations perform with respect to the observations. To do so, we need to run a forward simulation for 2010:2012 of which we keep all the interesting results. We want to generate two plots, 1.) observed vs. simulated daily soil water storage in 2011 and 2012 , and 2.) a barplot showing the monthly values of water fluxes. To do so, we additionally select the monthly output datasets EVAPMON.ASC and BELOMON.ASC:

optionsKAU\$enddate <- as.Date("2012-12-31") output [c("Evap", "Belo"), "Mon"] <- 1L

To perform the forward prediction run, we extract the behavioral parameter sets, without the run identifier:

par_pred <- data.frame (paramvar[singlerun \%in\% beh, ]) [, -which(names (paramvar) \%in\% "singlerun")]

No we can make forward prediction using the 244 behavioral parameter sets.

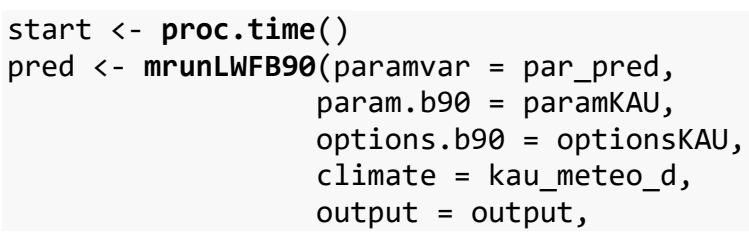




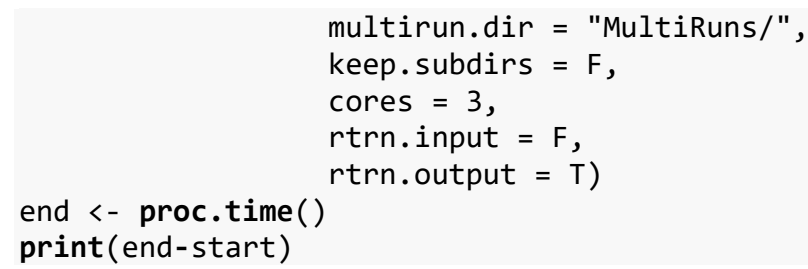

Using 3 CPUs, the prediction run takes less than 10 minutes. Now we need to extract the results from the singlerun list items:

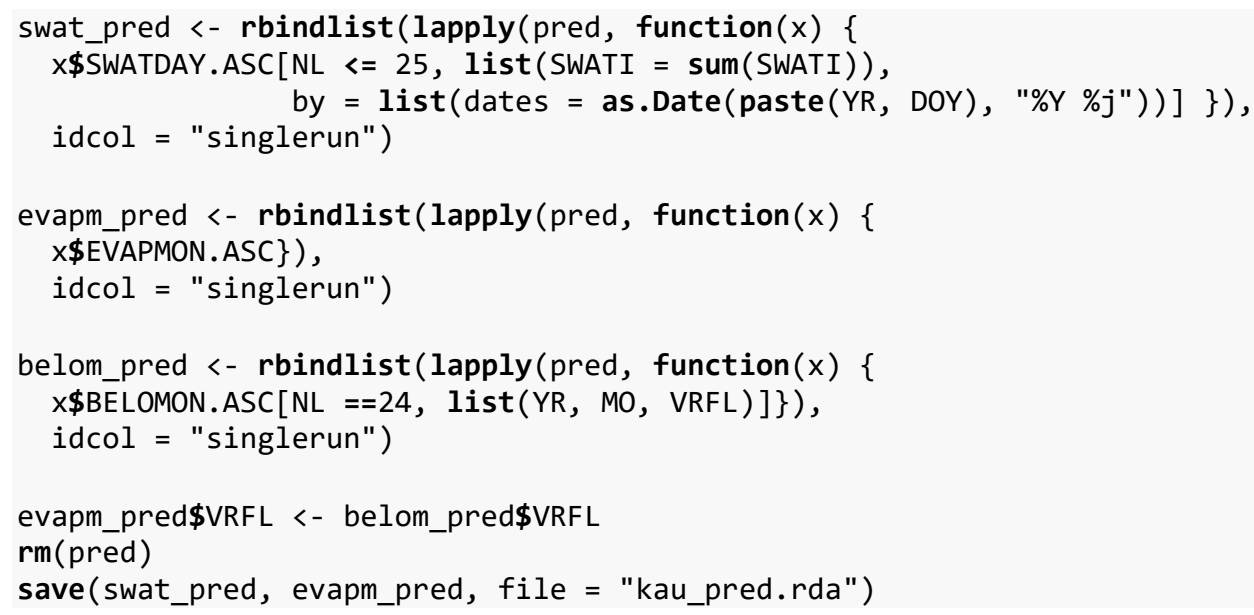

Now we can plot predicted vs. observed water storage. For the simulated values, we will display some daily summary statistics from the prediction ensemble, that we need to calculate first. To do so, will first melt the simulated water storage of the singleruns, and then cast them back with an aggrgation function. We also calculate quantiles to plot upper and lower confidence bounds. After all everything is merged with the observations, so that the statistics of the simulations and observed values are in organized in columns.

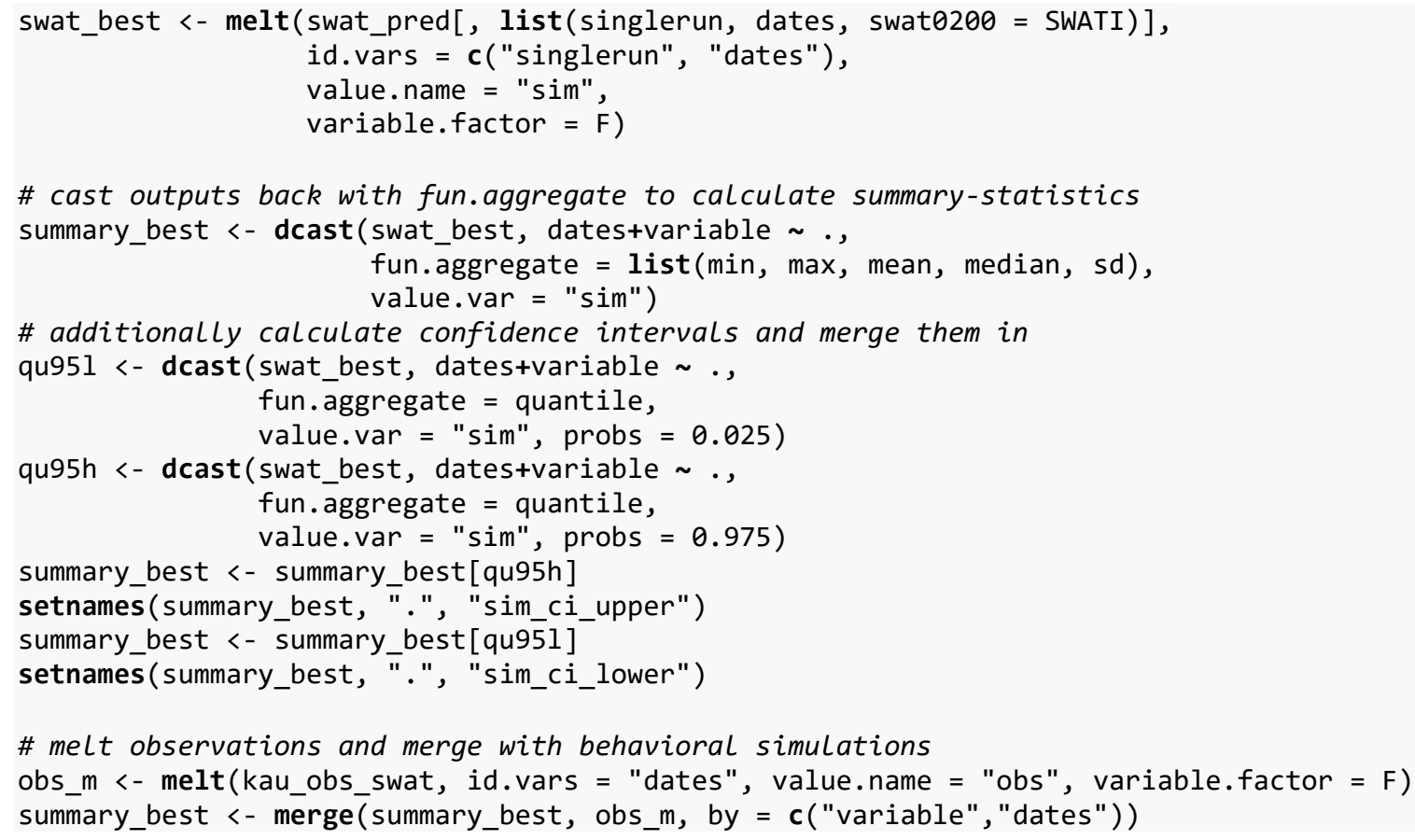

Now we can plot the daily simulation output of the behavioral simulations for the years 2011 and 2012, to compare model output with observations. The soil water storage at all times is within the $95 \%$ confidence bounds of the simulations, and during the calibration period (2011) also within the standard deviation. In the validation period (2012) observations are at the upper limit of confidence.

plotyrs <- 2011:2012

P_modperf_swat <- ggplot(summary_best[year(dates) \%in\% plotyrs , ], 

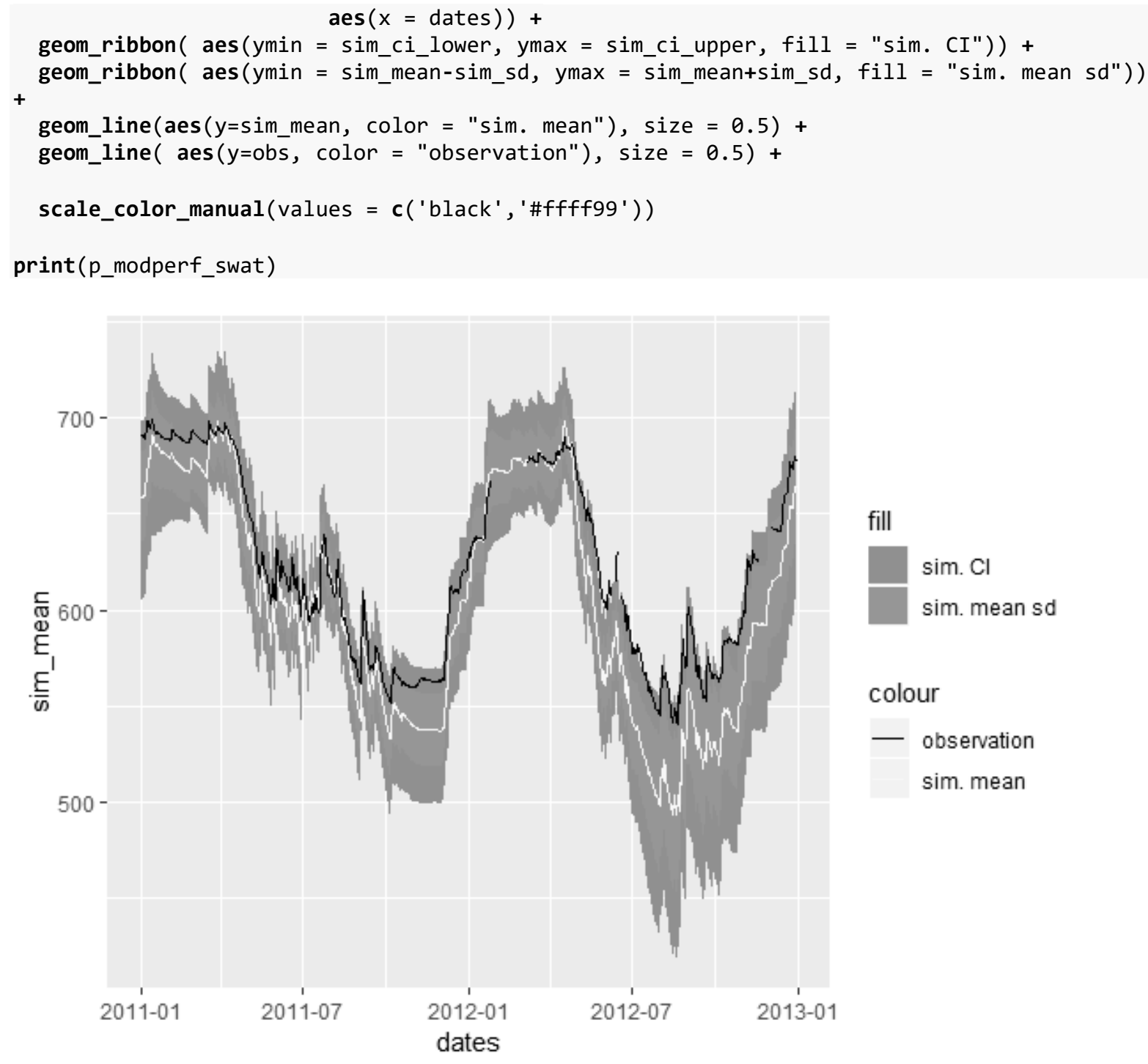

Now lets plot the monthly water fluxes. We would like to plot ensemble mean values of the individual evaporation fluxes and runoff as negative values.

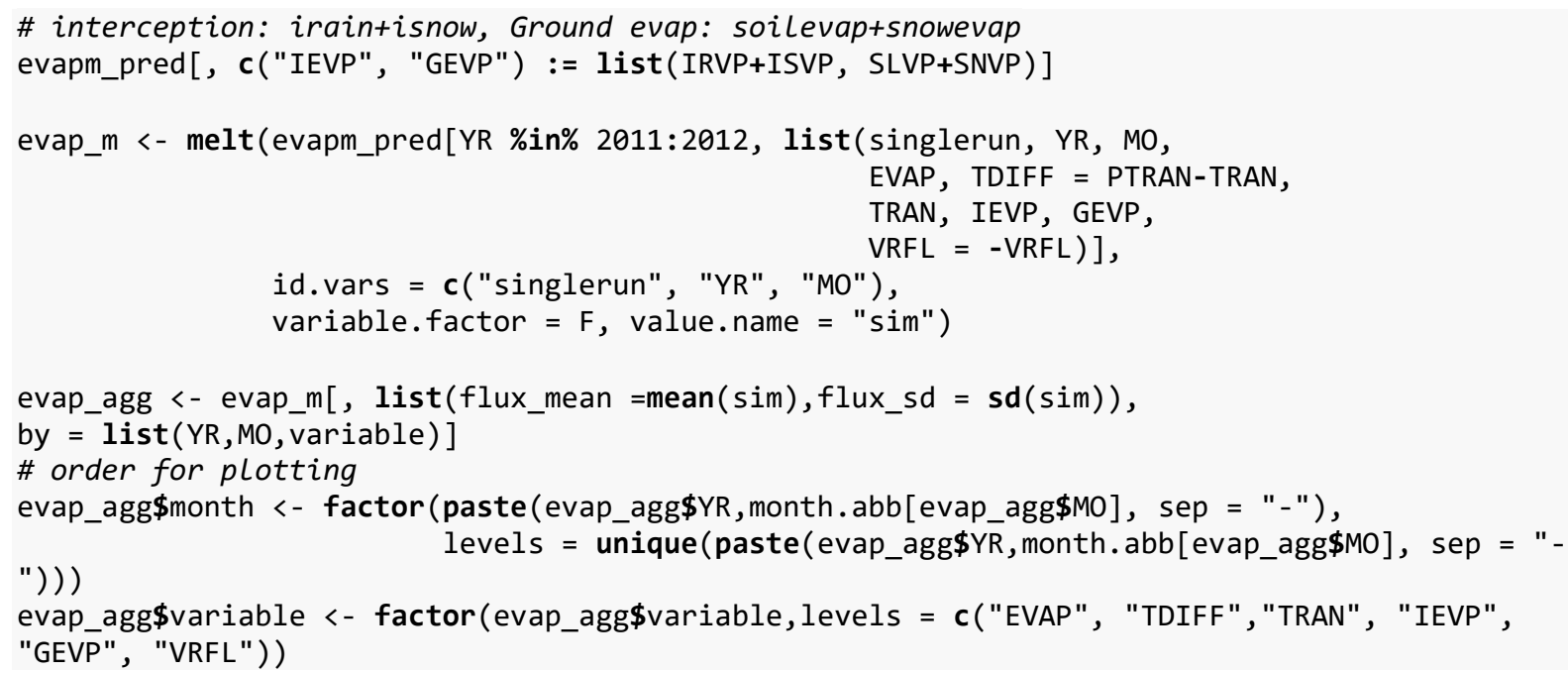




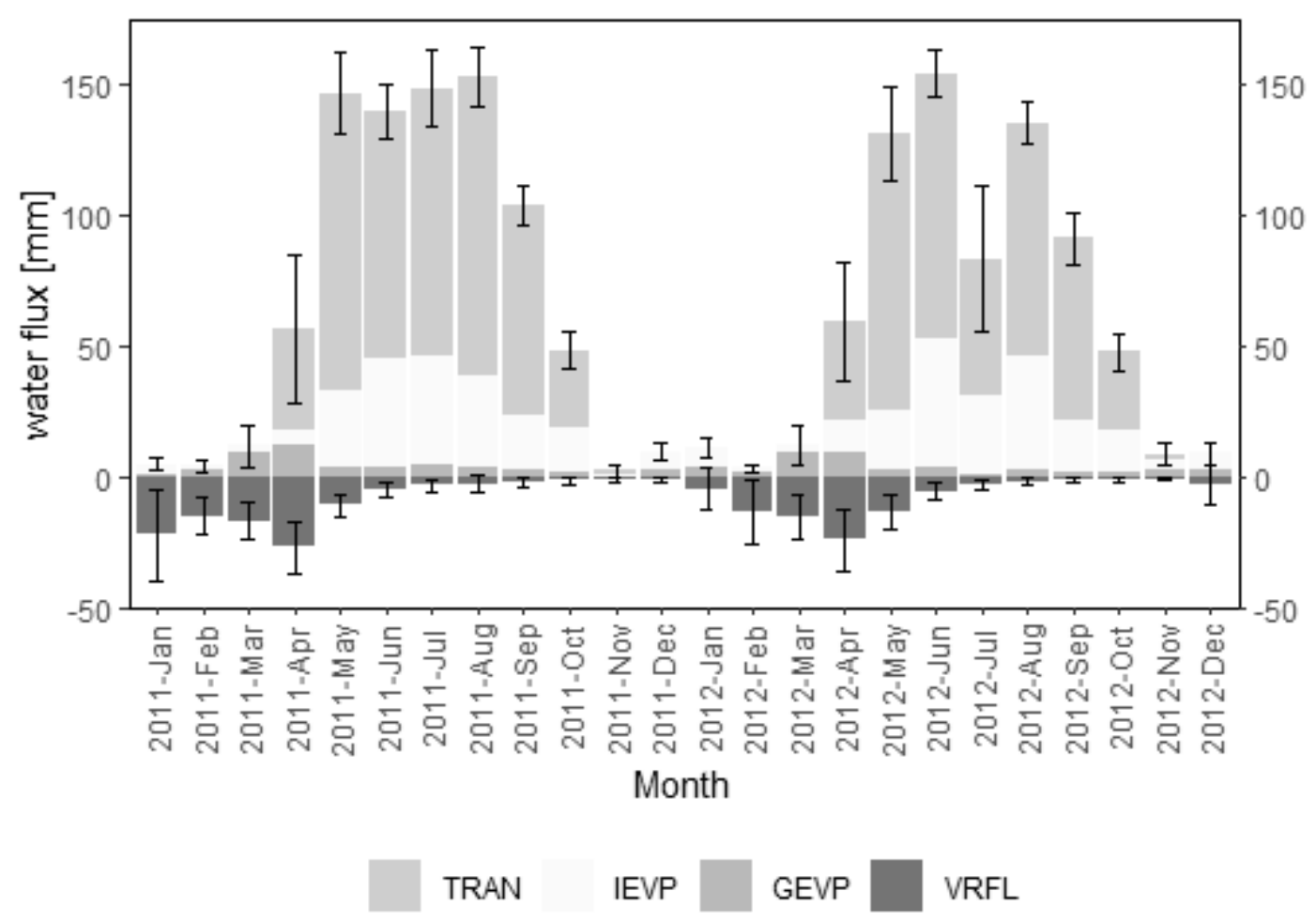

Mean monthly water fluxes of behavioral simulations ( $n=244)$. Errorbars show standard deviations total evapotranspiration (GEVP+IEVP+TRAN) and seepage flux (VRFL). 


\section{Bayesian calibration of "Kaufering Pappel Schacht 2011-2012"}

In this script a Bayesian calibrations using DE-MCzs sampler will be performed. For model calibration we will construct the custom likelihood function based on the runLWFB90 function. Be sure to download and unzip the folder 'DataAndPreparedResults.zip' to be able to load prepared results and input data to the R-workspace. See Appendix A for details.

Bayesian calibration requires the following steps:

- $\quad$ prepare the initial state of the model and forcing data

- $\quad$ prepare the observational data

- $\quad$ prepare the prioor parameter distributions

- construct the likelihood function

- run the Bayesian calibration and check for convergence

- check the posteriori distibution

- $\quad$ evaluate the model using sample from a posteriori distribution

Before starting the analysis, we need to load the required packages.

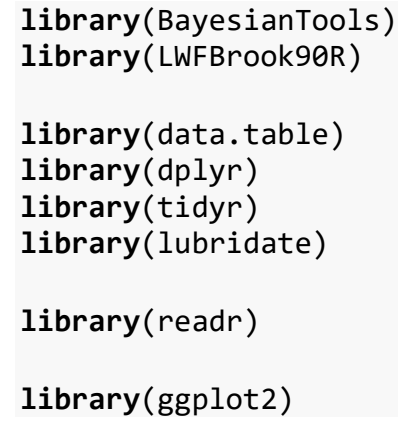

\section{D1 Model set up}

As a first step, we will load soil, meteorological, and observation data for the Kaufering poplar site and set up model input objects for runLWFB90, the same way as in the sensitivity analysis.

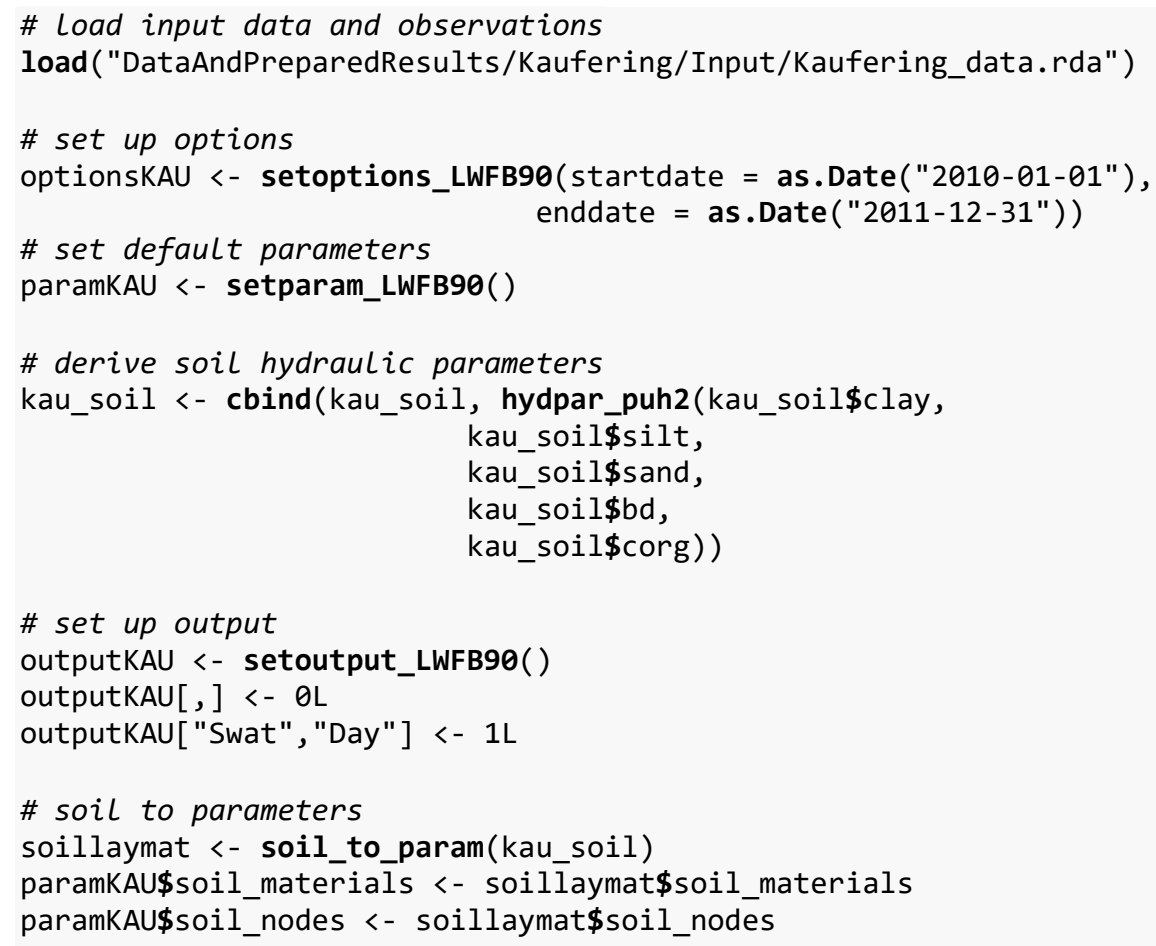


\# fixed, nonstandard param paramKAU $\$$ coords_y $<-48.09$ paramKAU\$height $<-12$ paramKAU \$ZW <- 10 paramKAU\$maxlai $<-6$

\section{D2 Prepare observations}

Now we prepare observed soil water storage data. We will split up the observations into a calibration and a validation dataset.

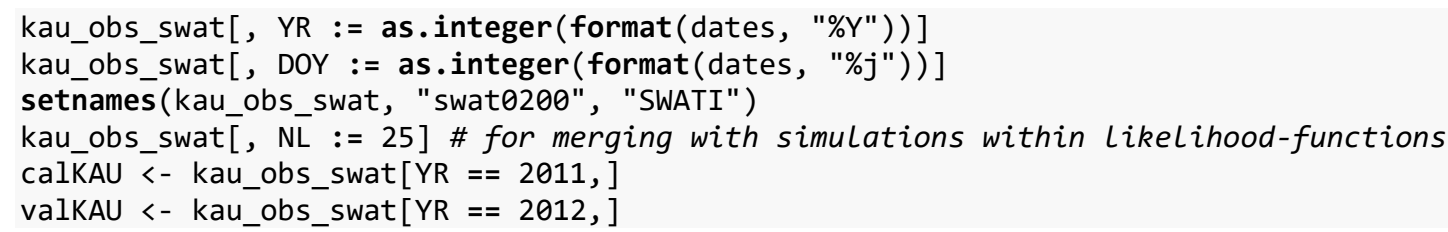

\section{D3 Prior ranges}

As prior, we set the uniform distribution of the sensitive parameters. We use scaling factors to vary the parameters ths and ksat of all layers simulatenously. Using the scaling factors, the values of the single layers are subsequently defined from the original layer value and the scaling factor. As a last step, we save our parameter sample.

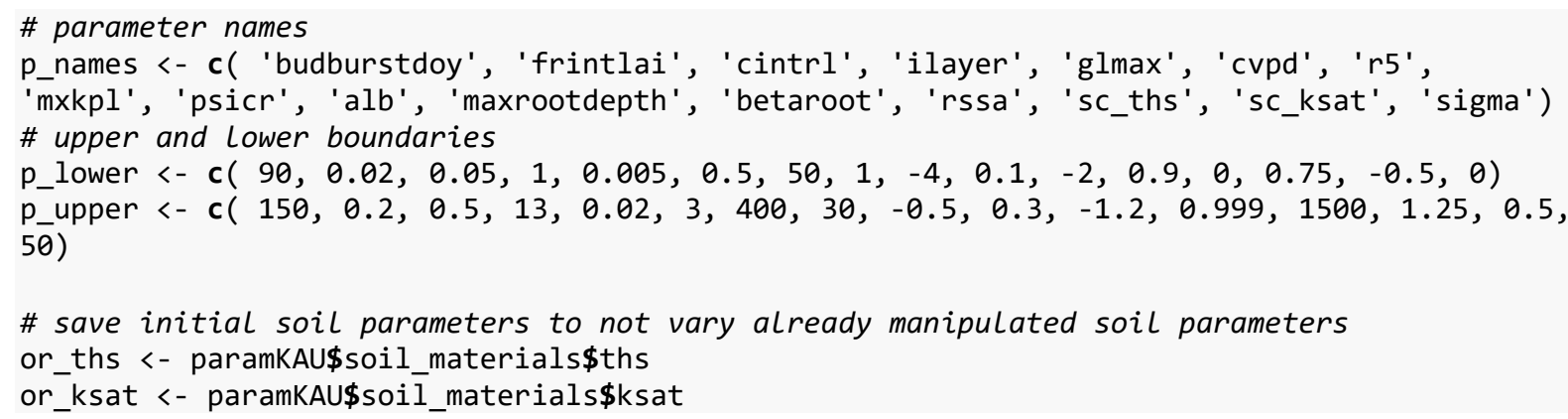

\section{D4 Definition of the likelihood function}

As previously mentioned, we need a custom function that runs the model and calculates the likelihood from simulation results and observations. The custom function will be later used inside the runMCMC function from BayesianTools package.

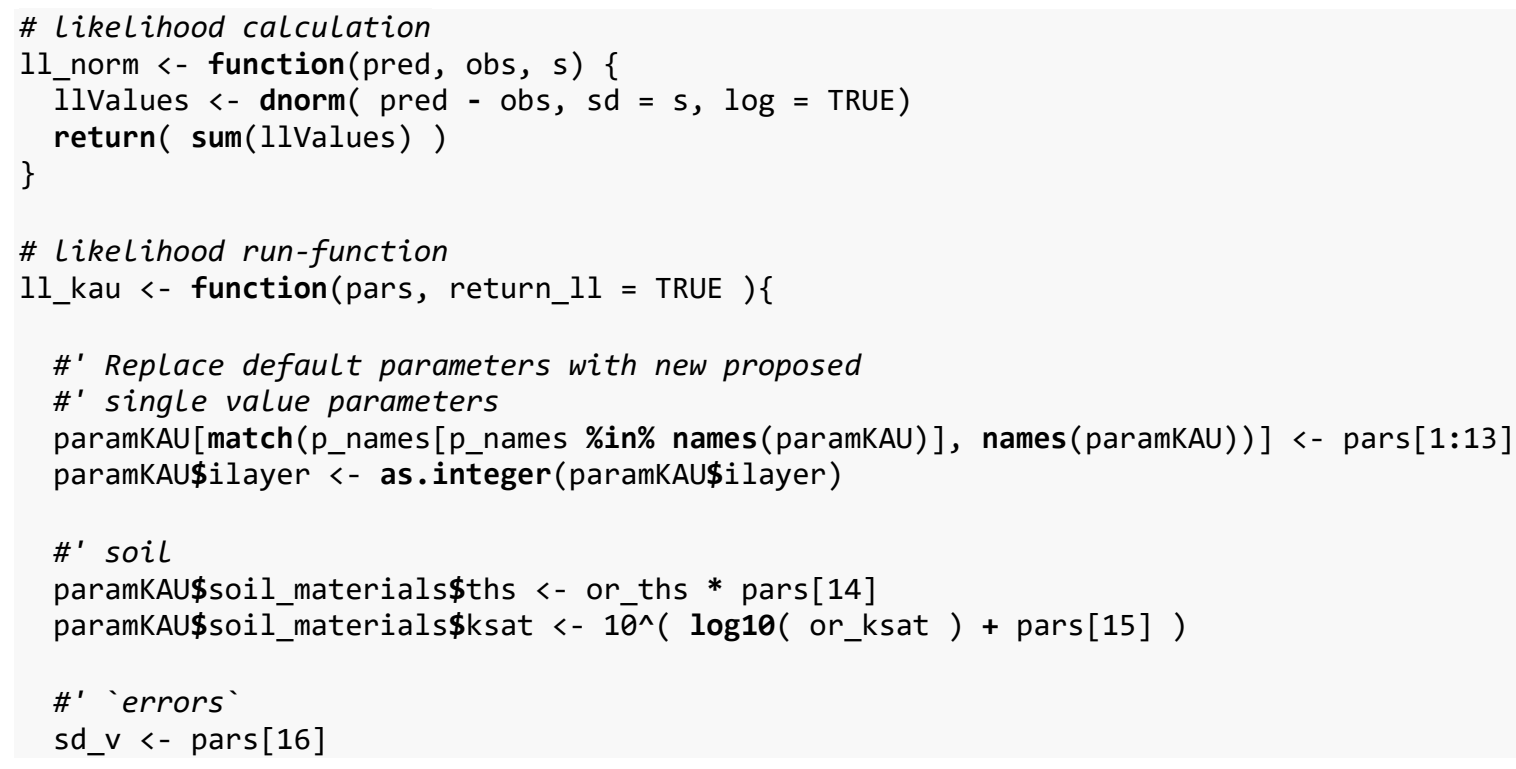




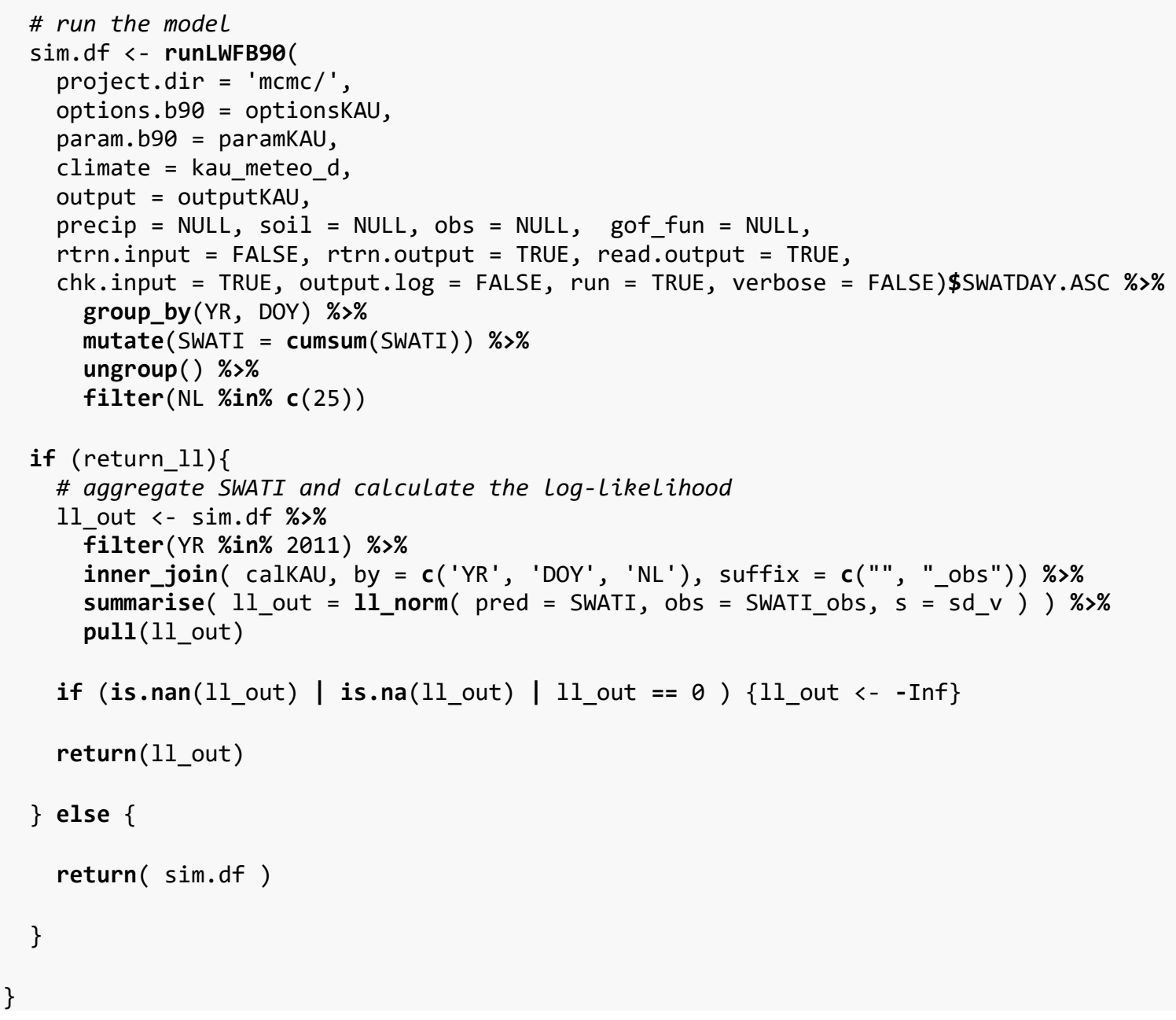

\section{D5 MCMC calibration}

Here we do the actual calibration, for the testing purposes please set the number of itereations to small number. We provide the full MCMC calibration file in the directory "DataAndPreparedResults/Kaufering/Results_D_Bayesian .

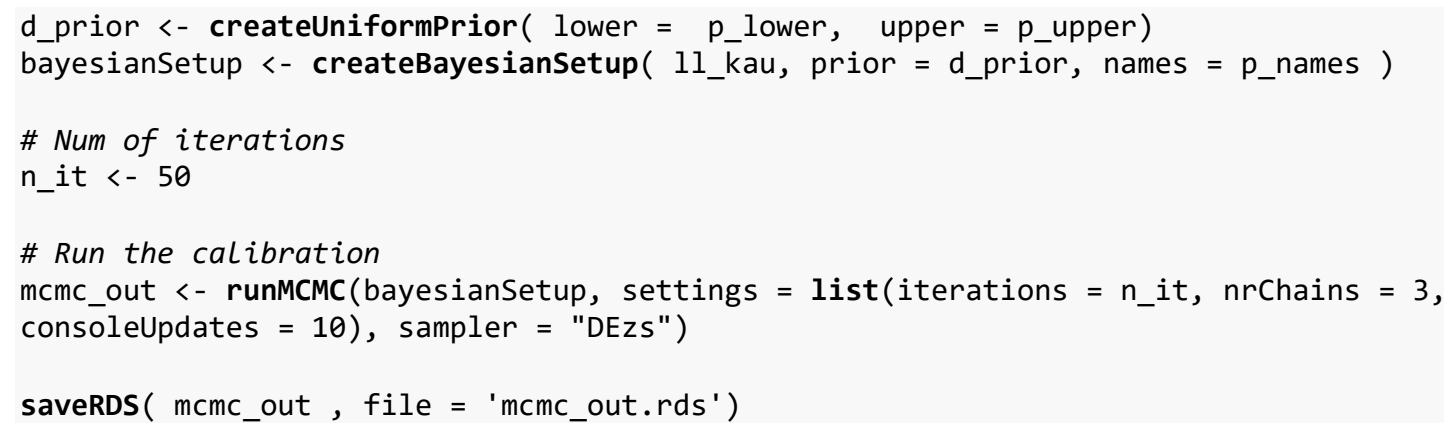

\section{D6 Posteriori evaluation}

After the simulation has finsihed, wie load the simulation file back to the work-space.

mcmc_out <- read_rds('DataAndPreparedResults/Kaufering/Results_D_Bayesian/mcmc_out.rds' )

With following commands, the chain summary, convergence information and traceplots can be viewed. 


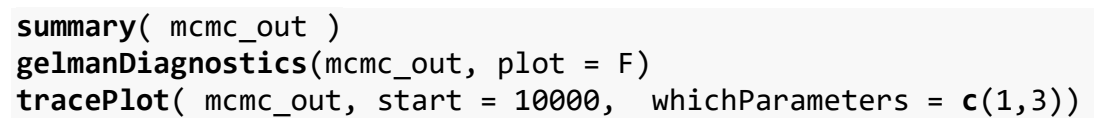

\section{D7 Posteriori parameter distributions}

To evaluate change in posteriori distribution we visualize the prior and posterior parameter distributions. The figure below shows the posteriori density of the parameters, while the width of the $x$ axis shows the range of the prior parameters. We start with drawing a sample of $\mathrm{N}=1000$, that we will later also use for the prediction.

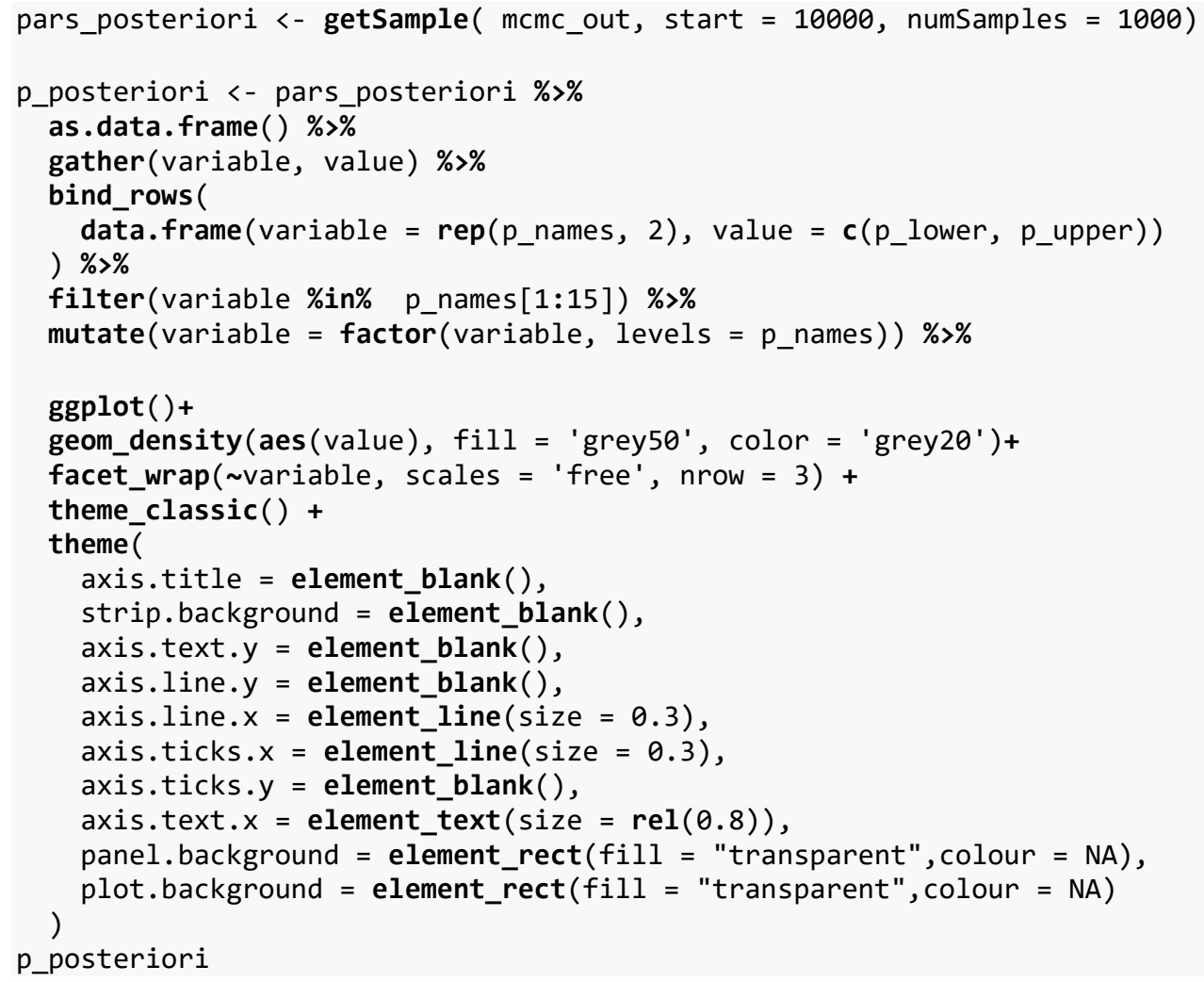




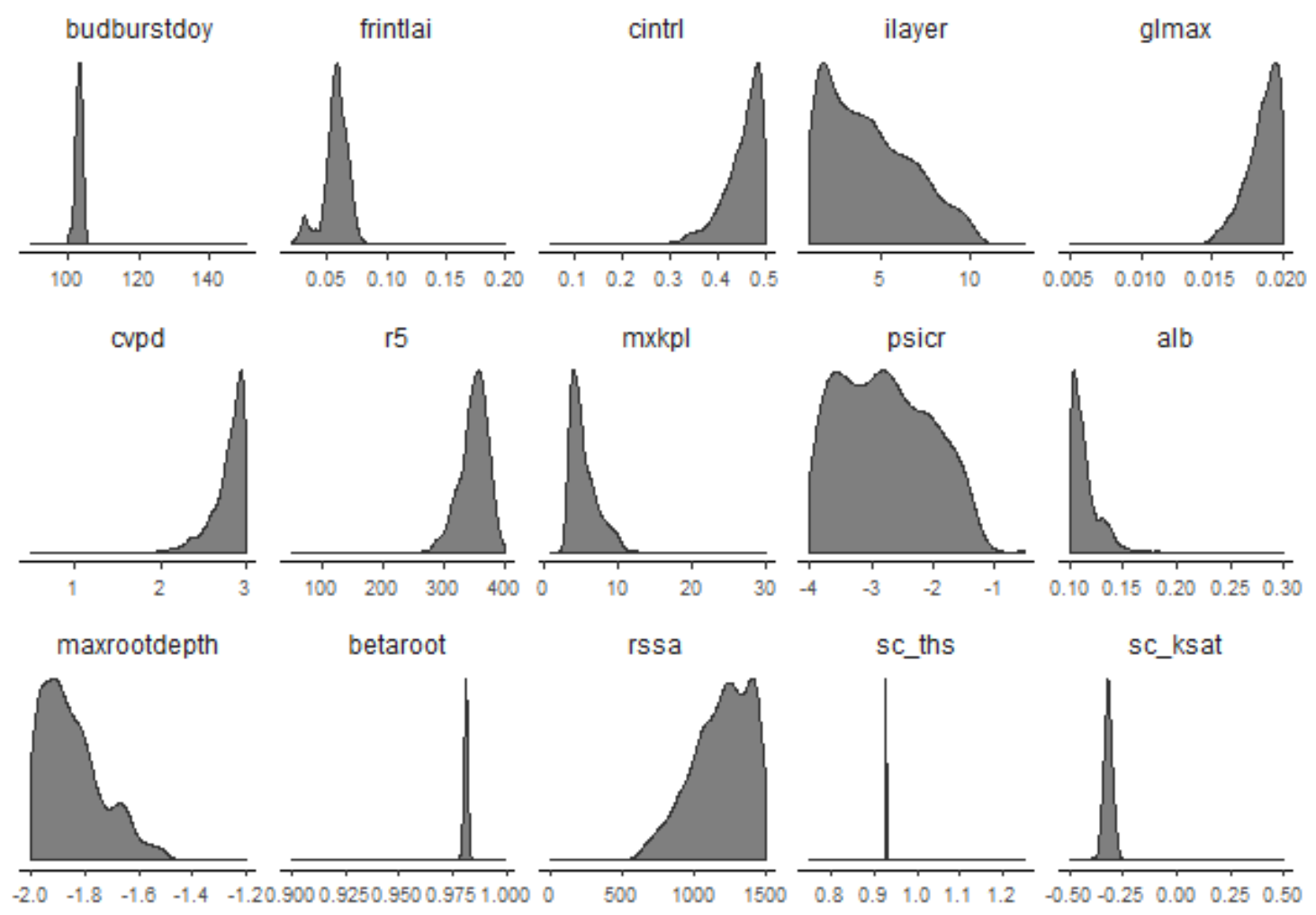

\section{D8 Posterior prediction}

Now we make a prediction from the sample using the function mrunLWFB90. On a desktop computer using 3 cores, the simulation of 1000 samples takes about 45 minutes to finish. The prediction results are provided within 'DataAndPreparedResults/Kaufering/Results_5_Bayesian', and we will only make a smaller number of simulations here. We first prepare the parameters, then set up and run the prediction and finally aggregate and save the results.

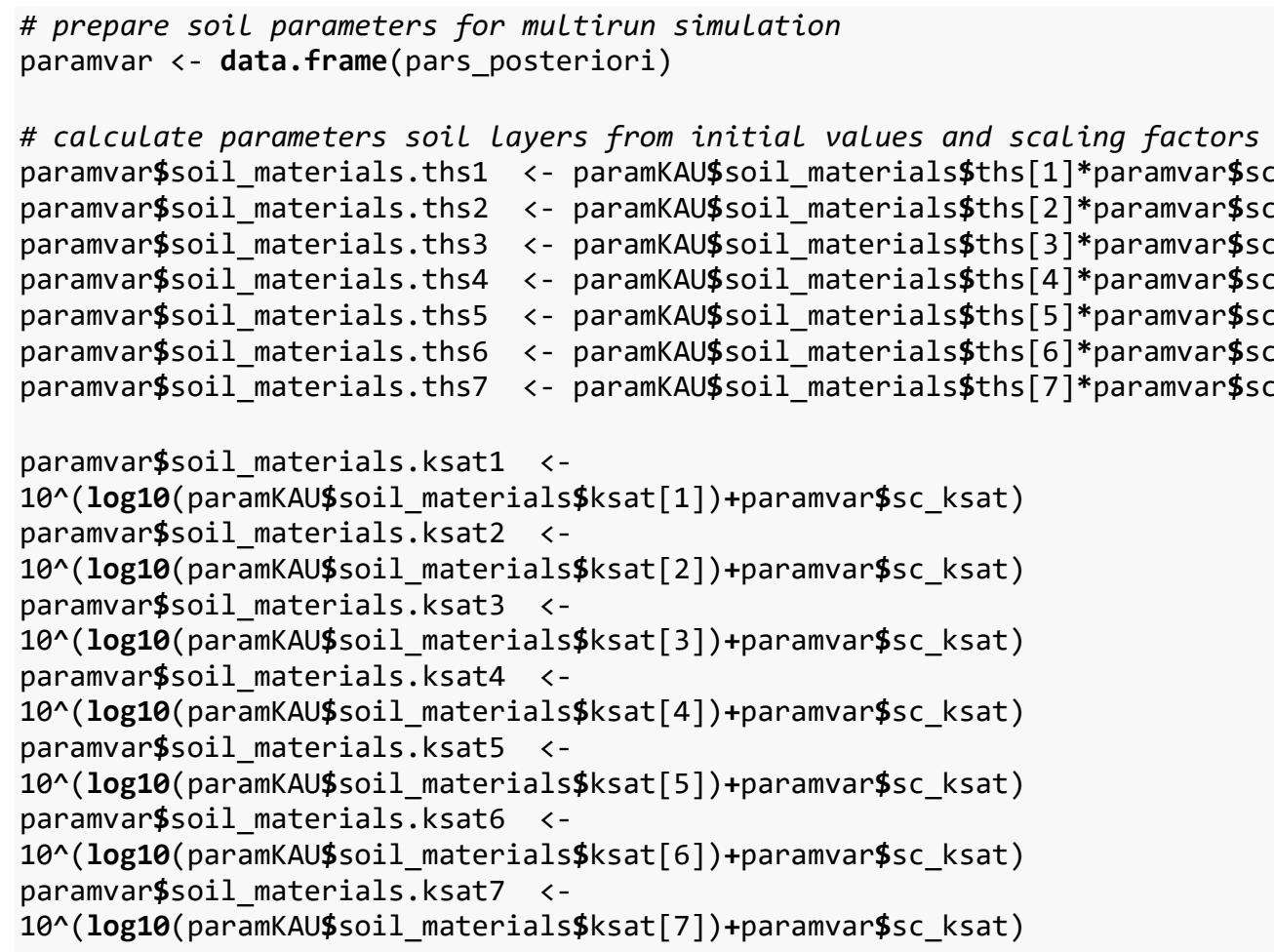


\# remove unused parameters

paramvar[,c("sc_ths", "sc_ksat", "swat_sd" )] <- NULL

Set up and run the simulation, then aggregate and save the results:

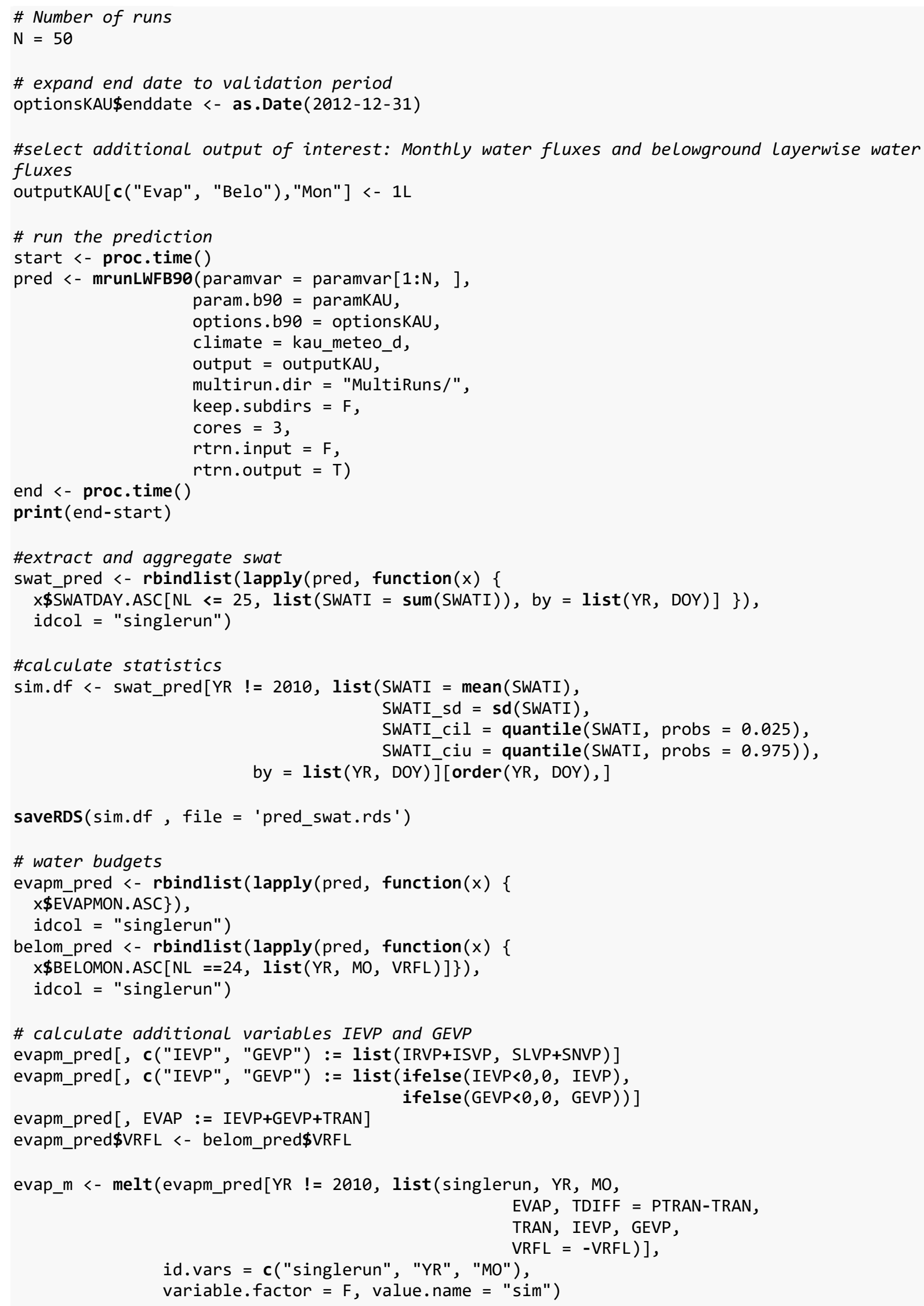




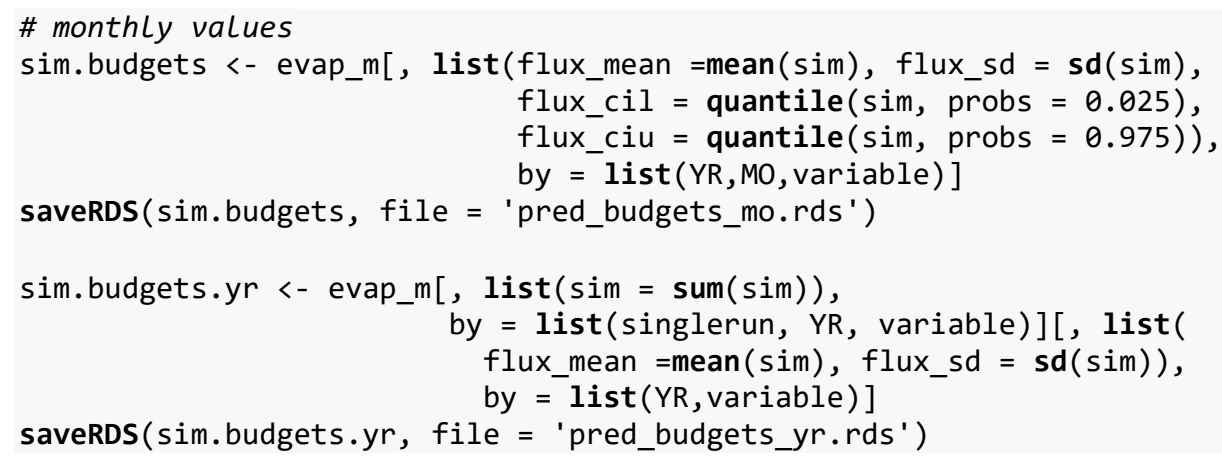

Now we can plot mean simulated soilwater storage including uncertainties, to compare with observations.

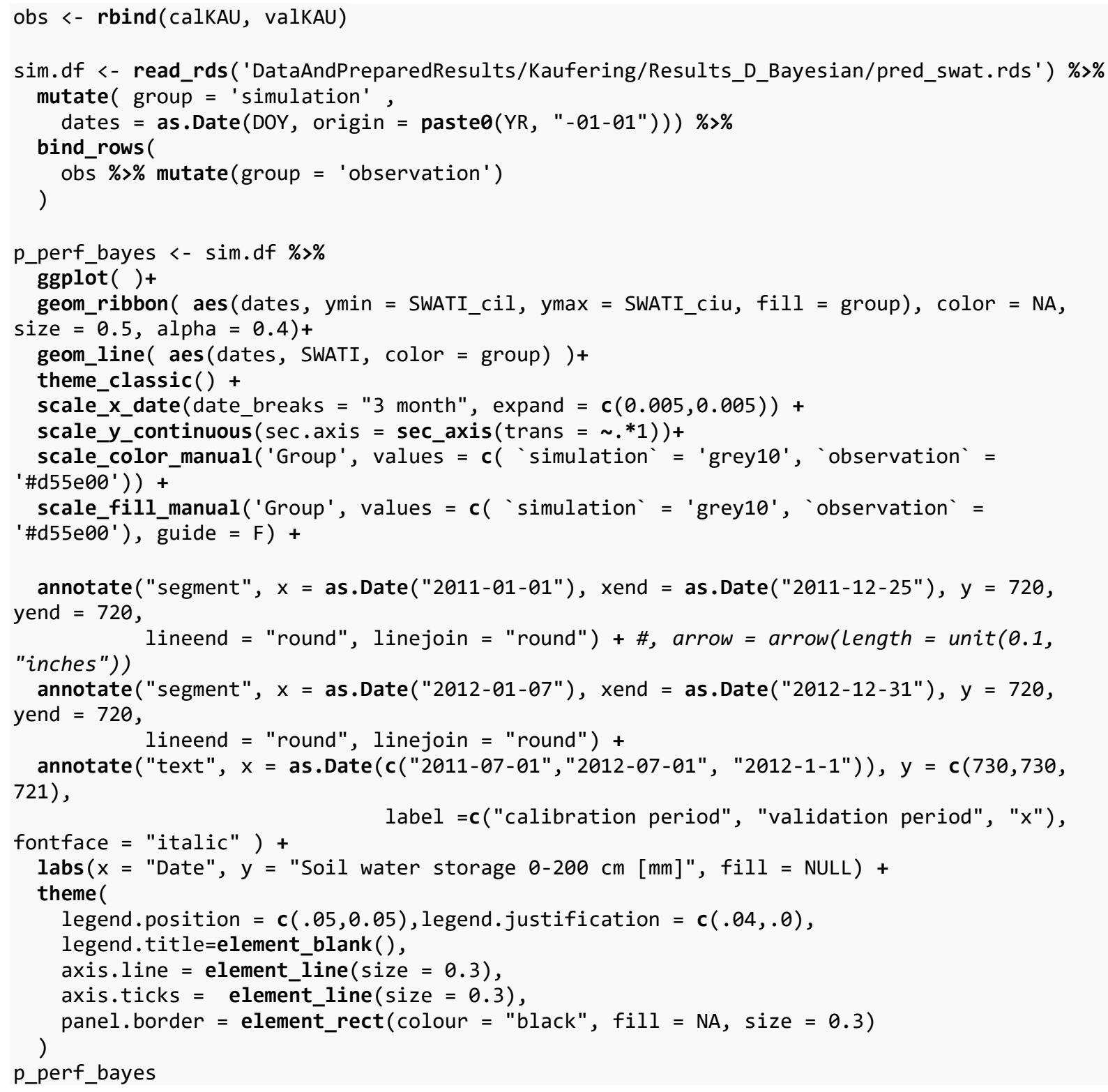




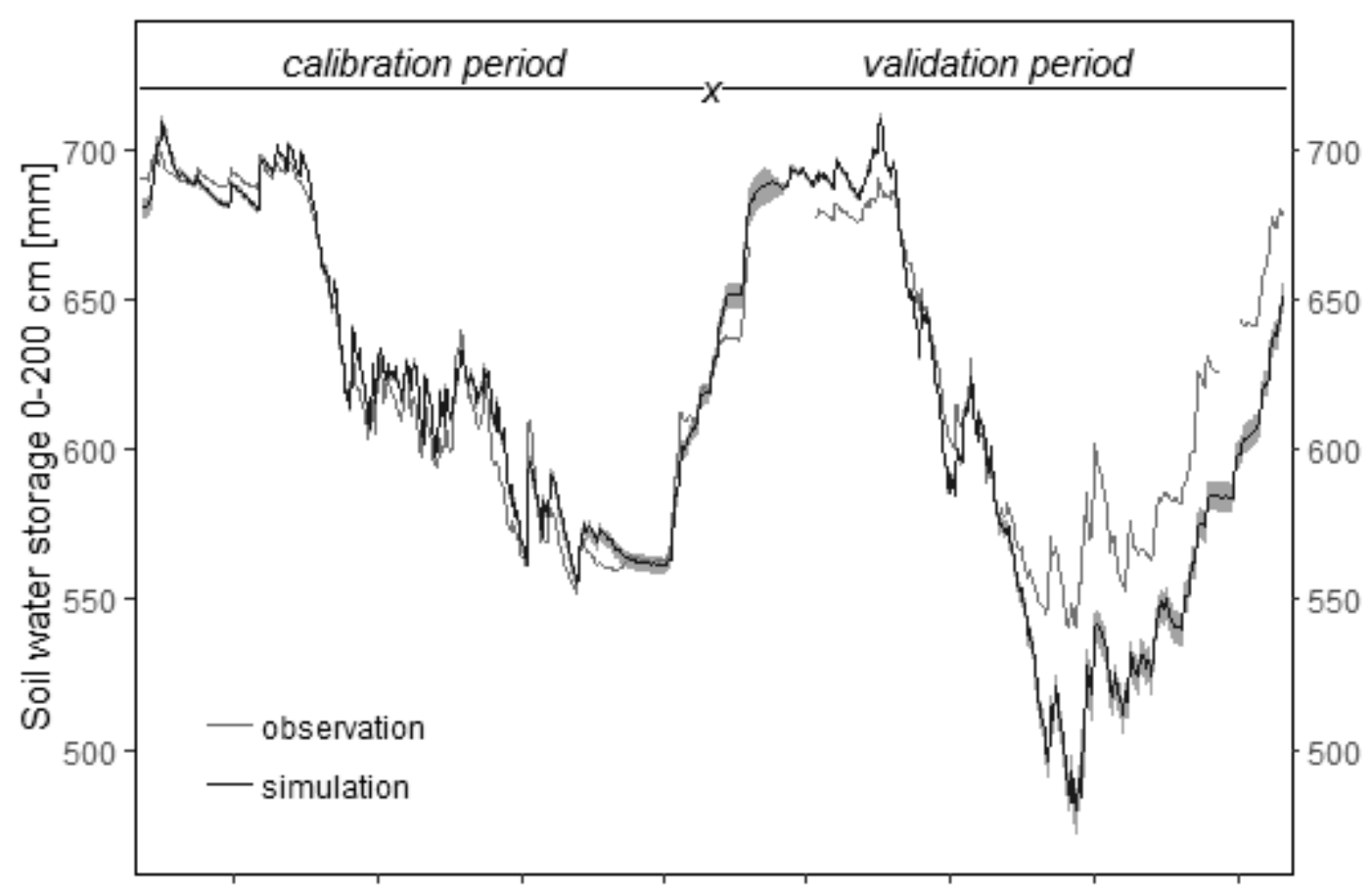

2011-03-09011-06-08011-09-08011-12-08012-03-09012-06-08012-09-09012-12-01

Date

We also plot monthly predicted water fluxes.

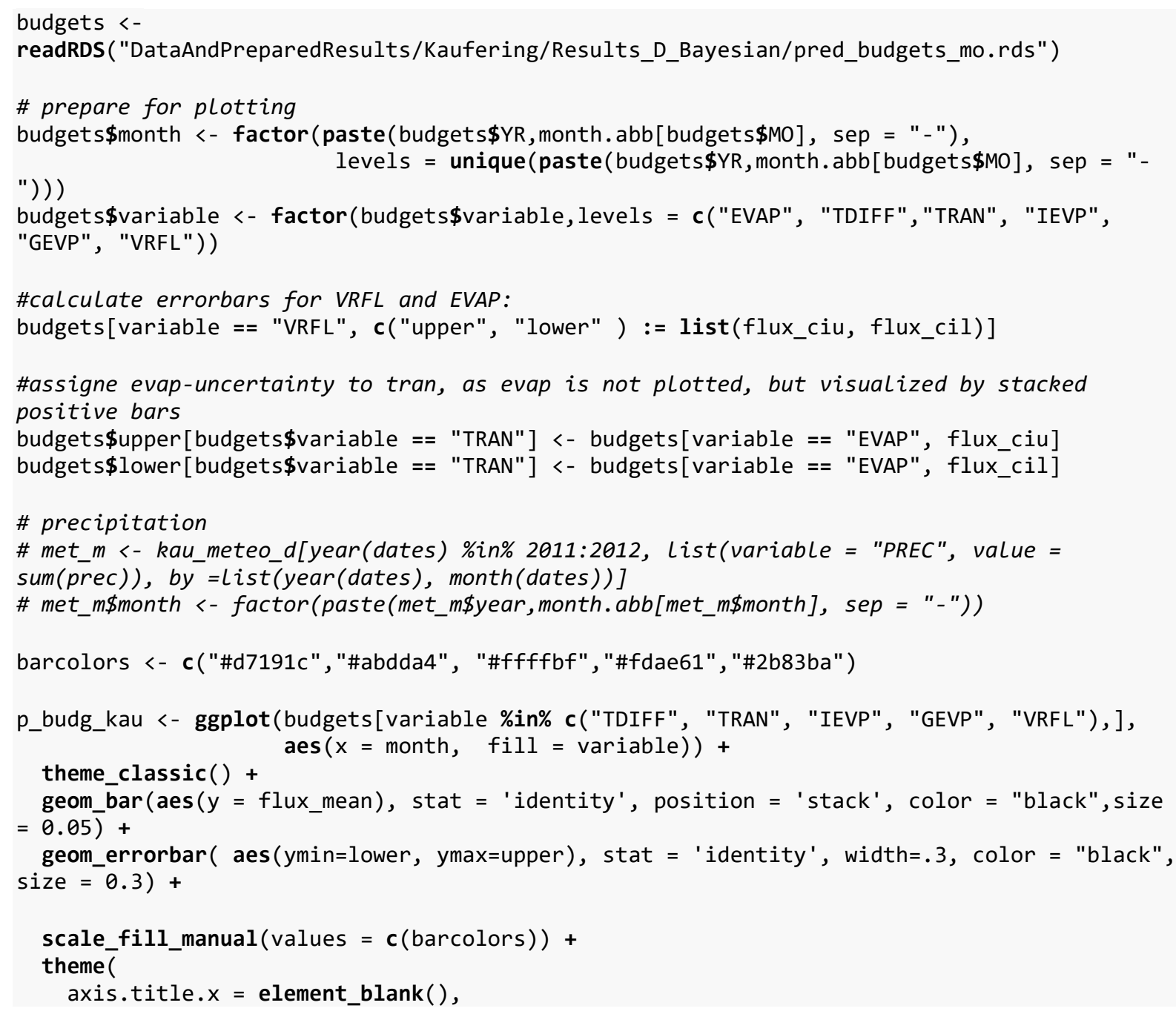


axis.text. $x=$ element_text $($ angle $=90$, vjust $=0.5)$, legend.position = "bottom",

panel .border $=$ element_rect $($ colour $=$ "black", fill $=$ NA, size $=0.3)$,

axis.line $=$ element_line $($ size $=0.3)$,

axis.ticks $=$ element_line $($ size $=0.3))+$

$\operatorname{labs}(y=$ "Water flux $[\overline{\mathrm{mm}}] "$, fill $="$ ", title $=$ NULL $)+$

scale_y_continuous $(\mathrm{sec}$.axis $=$ sec_axis $(\operatorname{trans}=\sim . * 1)$ )

P_budg_kau
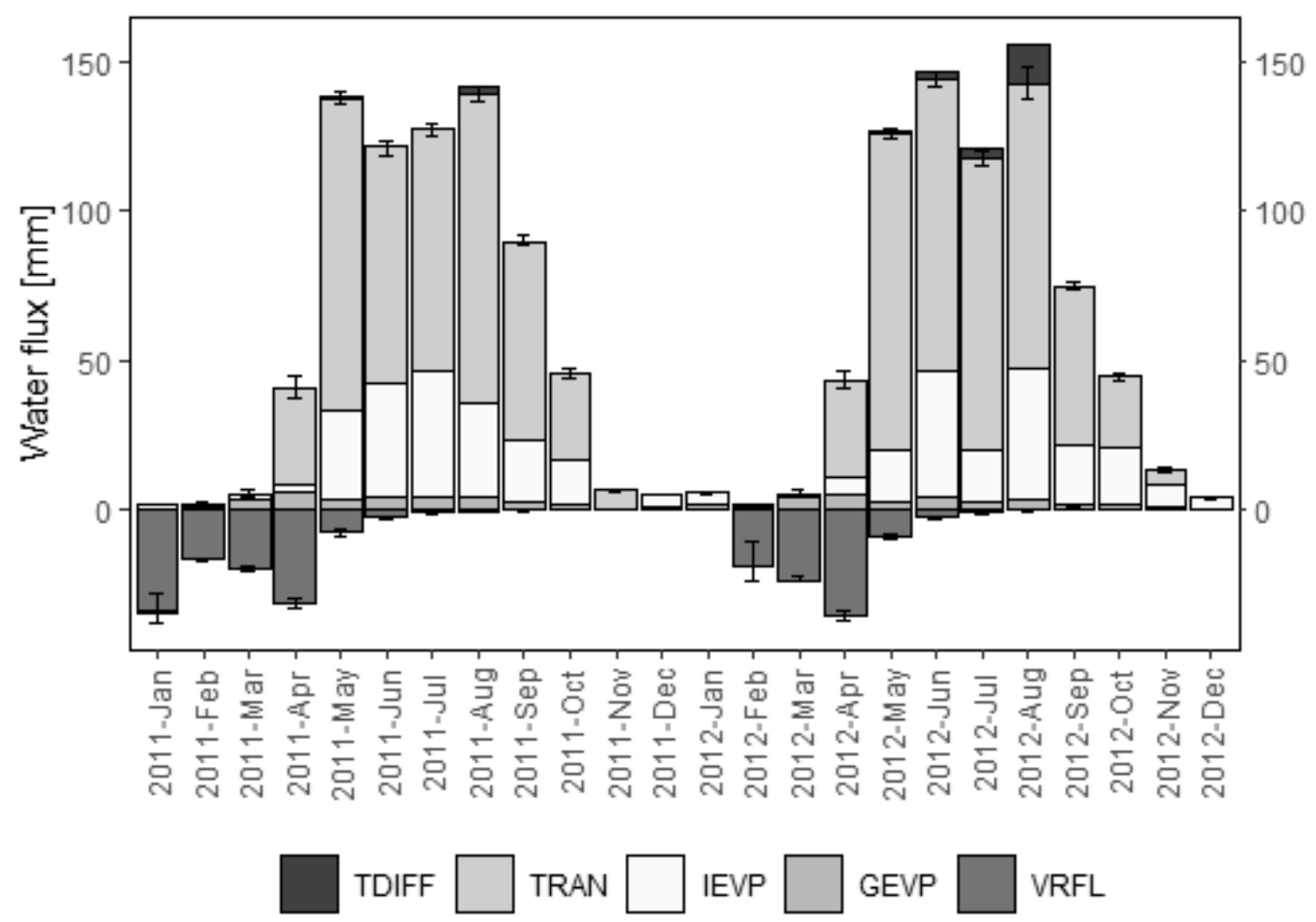

Table of yearly values:

readRDS("DataAndPreparedResults/Kaufering/Results_D_Bayesian/pred_budgets_yr.rds")

\#> YR variable flux_mean flux_sd

\#> 1: $2011 \quad$ EVAP $720.661210 \quad 5.192875$

\#> 2: 2012 EVAP $720.615079 \quad 5.984420$

\#> 3: $2011 \quad$ TDIFF $\quad 3.413393 \quad 1.998507$

\#> 4: 2012 TDIFF $19.464087 \quad 5.738667$

\#> 5: $2011 \quad$ TRAN $503.639087 \quad 14.545884$

\#> 6: 2012 TRAN 512.205556 14.342563

\#> 7: 2011 IEVP 187.62956317 .068311

\#> 8: 2012 IEVP $182.860417 \quad 15.381587$

\#> 9: $2011 \quad$ GEVP $29.062599 \quad 4.837268$

\#> 10: 2012 GEVP $25.525000 \quad 4.410238$

\#> 11: $2011 \quad$ VRFL $-116.899603 \quad 3.540937$

\#> 12: 2012 VRFL -92.4100204 .366048$ 